Prepared for the California State Water Resources Control Board and Bureau of Reclamation

\title{
Salton Sea Ecosystem Monitoring Project
}

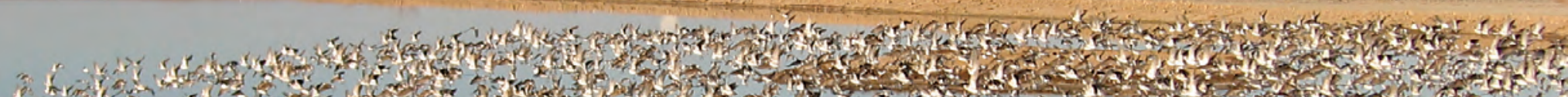

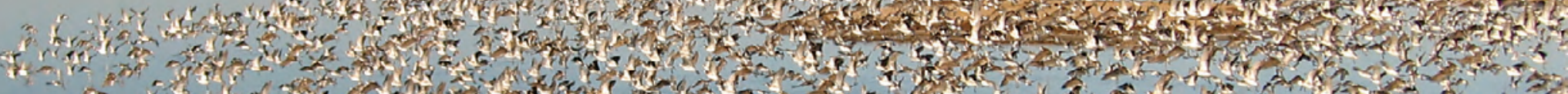

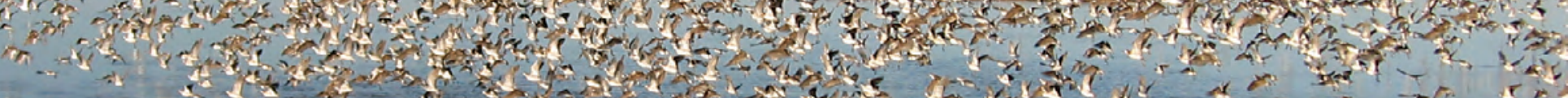

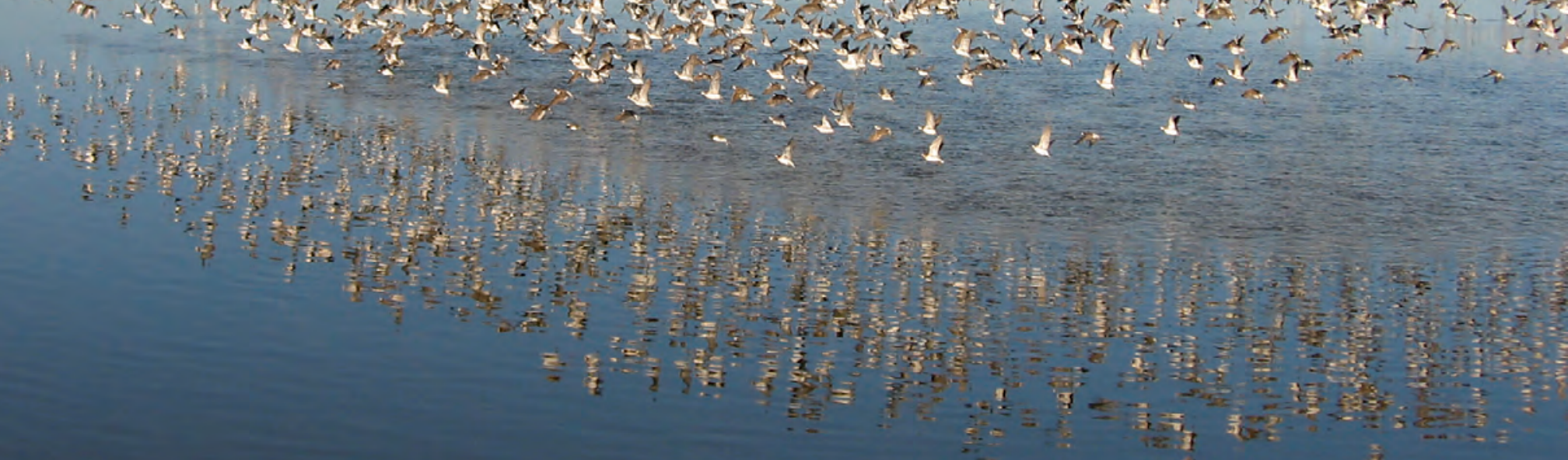

Open File Report 2009-1276 
Cover: A flock of Wilson's Phalaropes create a reflection while flying over constructed saline habitat ponds (SHP), Salton Sea, California. Numerous species of waterbirds rapidly inhabited the SHP after completion in March 2006, and continue to use the SHP for foraging, roosting, and nesting activities. (Photograph courtesy of Tom Anderson, U.S. Geological Survey, Salton Sea Science Office.) 


\section{Salton Sea Ecosystem Monitoring Project}

By A. Keith Miles, Mark A. Ricca, Anne Meckstroth, and Sarah E. Spring

Prepared for the California State Water Resources Control Board and Bureau of Reclamation

Open-File Report 2009-1276

U.S. Department of the Interior

U.S. Geological Survey 


\section{U.S. Department of the Interior \\ KEN SALAZAR, Secretary}

\section{U.S. Geological Survey \\ Marcia K. McNutt, Director}

U.S. Geological Survey, Reston, Virginia: 2009

For more information on the USGS-the Federal source for science about the Earth, its natural and

living resources, natural hazards, and the environment, visit http://www.usgs.gov or call 1-888-ASK-USGS.

For an overview of USGS information products, including maps, imagery, and publications, visit $h$ ttp://www.usgs.gov/pubprod

To order this and other USGS information products, visit $h$ ttp://store.usgs.gov

Suggested citation:

Miles, A.K., Ricca, M.A., Meckstroth, A., and Spring, S.E., 2009, Salton Sea Ecosystem Monitoring Project: U.S. Geological Survey Open-File Report 2009-1276, 150 p.

Any use of trade, product, or firm names is for descriptive purposes only and does not imply endorsement by the U.S. Government.

Although this report is in the public domain, permission must be secured from the individual copyright owners to reproduce any copyrighted material contained within this report. 


\section{Contents}

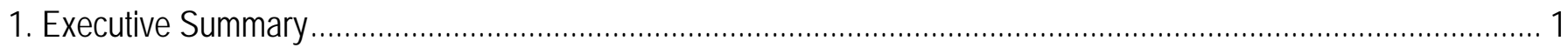

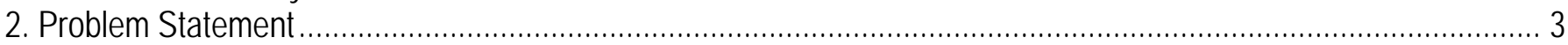

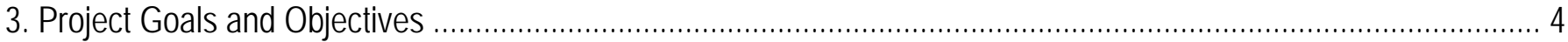

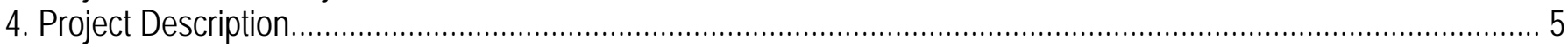

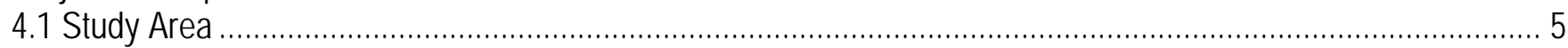

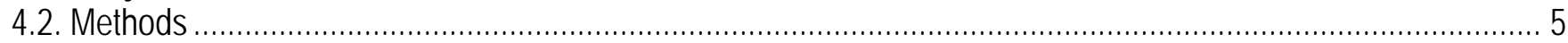

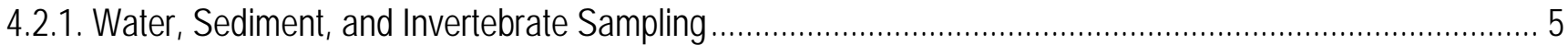

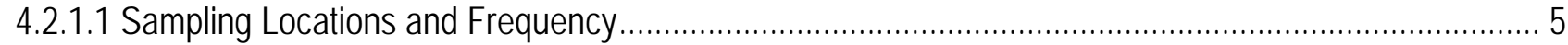

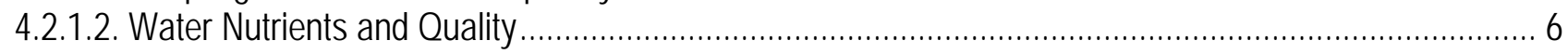

4.2.1.3. Water Inorganic and Organic Contaminants ............................................................................. 6

4.2.1.4. Sediment Chemistry and Composition ............................................................................... 7

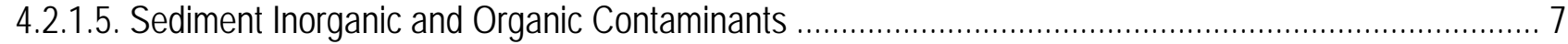

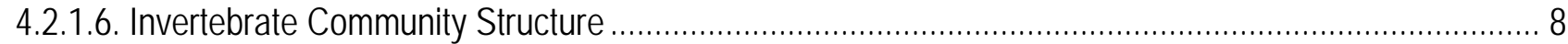

4.2.1.7. Invertebrate Inorganic and Organic Contaminants ................................................................ 8

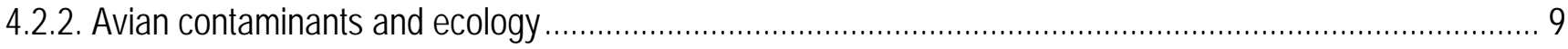

4.2.2.1. Inorganic and Organic Contaminants in Black-necked Stilt Eggs ….............................................. 9

4.2.2.2. Post-Hatch Movement and Survival..................................................................................10

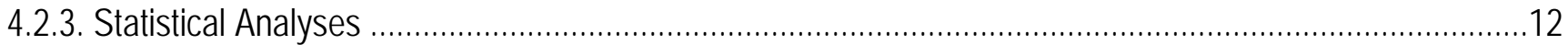

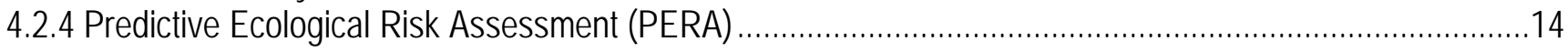

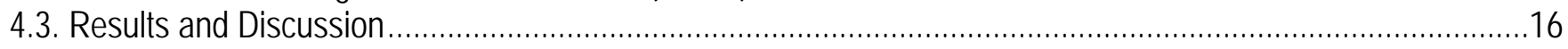

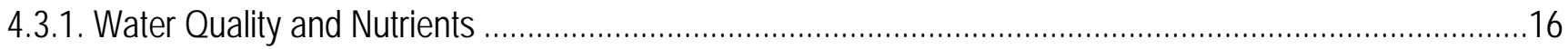

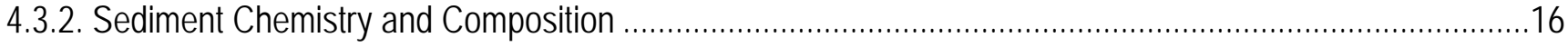

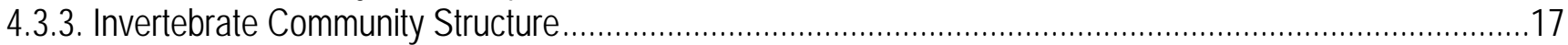

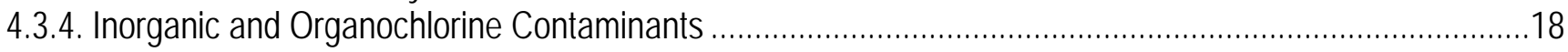

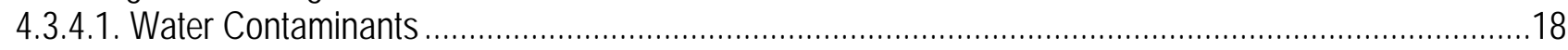

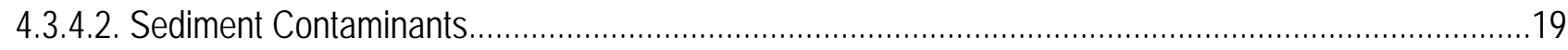

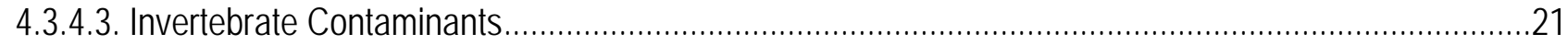

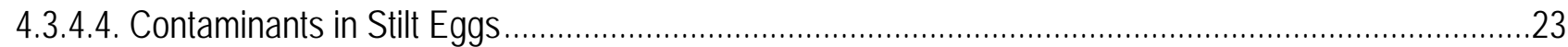

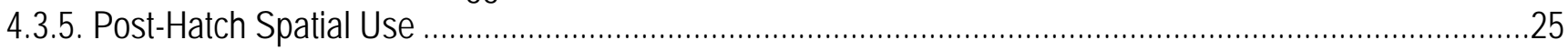

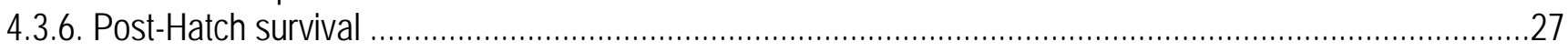

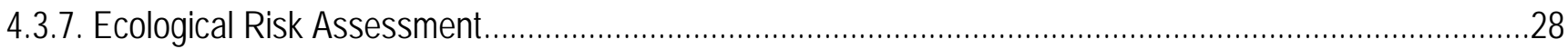

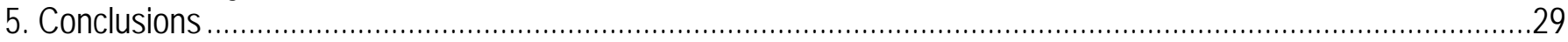

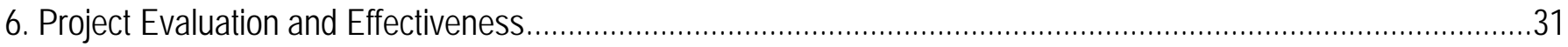

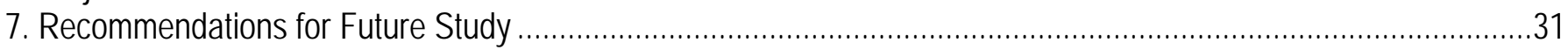

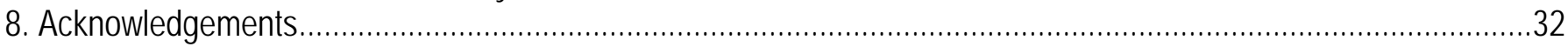

9. References Cited

10. Figures

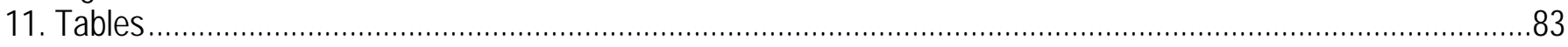

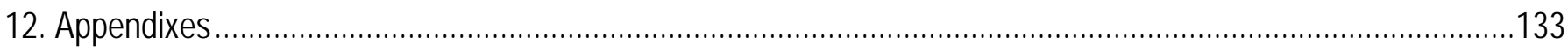




\section{Figures}

Figure 1. Sampling points, Ecosystem Monitoring Project, Salton Sea, California, 2006-08 ……........................... 37

Figure 2. Black-necked Stilt egg collection locations, 2006, 2007, 2008, Ecosystem Monitoring Project, Salton Sea, California......

Figure 3. Averages (+ 1 standard deviation) for salinity concentrations in water samples collected from the saline habitat ponds (1-4) and reference sites, Ecosystem Monitoring Project, Salton Sea, California, fall 2006-fall 2008

Figure 4. Average chlorophyll-a concentrations in surface-water samples collected from the saline habitat ponds (1-4) and reference sites, Ecosystem Monitoring Project, Salton Sea, California, fall 2006-fall 2008

Figure 5. Abundance of macroinvertebrate taxa most frequently encountered at the saline habitat ponds (1-4) and reference sites, Ecosystem Monitoring Project, Salton Sea, California, fall 2006-fall 2008

Figure 6. Taxonomic family richness for macroinvertebrates sampled at the saline habitat ponds (1-4) and reference sites, Ecosystem Monitoring Project, Salton Sea, California, fall 2006-fall 2008

Figure 7. Non-metric multidimensional scaling ordination of macroinvertebrate community structure at the saline habitat ponds and reference sites, Ecosystem Monitoring Project, Salton Sea, California, fall 2006-fall 2008

Figure 8. Least-squares means (and 95-percent confidence intervals) for selenium concentrations in surface water samples collected from the saline habitat ponds and reference sites, Ecosystem Monitoring Project, Salton Sea, California, spring 2007-fall 2008

Figure 9. Average percentages (and 95-percent confidence intervals) for water samples collected from the saline habitat ponds and reference sites exceeding selenium toxicity threshold and background concentrations, Ecosystem Monitoring Project, Salton Sea, California, spring 2007-fall 2008

Figure 10. Principal components analysis ordination of elemental concentrations in surface water at the saline habitat ponds and reference sites, Ecosystem Monitoring Project, Salton Sea, California, fall 2006-fall 2008

Figure 11. Least-squares means (and 95-percent confidence intervals) for selenium concentrations in sediment samples collected from the saline habitat ponds and reference sites, Ecosystem Monitoring Project, Salton Sea, California, fall 2006-fall 2008.

Figure 12. Three dimensional principal components analyses ordination of elemental concentrations in sediments at the saline habitat ponds and reference sites, Ecosystem Monitoring Project, Salton Sea, California, fall 2006-fall 2008

Figure 13. Least-squares means (and 95-percent confidence intervals) for $p, p$ ' DDE concentrations in sediment samples collected from the saline habitat ponds and reference sites, Ecosystem Monitoring Project, Salton Sea, California, fall 2006-fall 2008.

Figure 14. Least-squares means (and 95-percent confidence intervals) for selenium concentrations in Corixidae samples collected from the saline habitat ponds and reference sites, Ecosystem Monitoring Project, Salton Sea, California, fall 2006-all 2008

Figure 15. Average percentages (and 95-percent confidence intervals) for Corixidae and Chironomidae samples collected from the saline habitat ponds and reference sites exceeding selenium toxicity threshold concentrations, Ecosystem Monitoring Project, Salton Sea, California, fall 2006-fall 2008.

Figure 16. Relationships between natural log transformed selenium concentrations in Corixidae and Chironomidae, and water and sediment samples from the saline habitat ponds and reference sites, Ecosystem Monitoring Project, Salton Sea, California, spring 2008-fall 2008.

Figure 17. Box plots for selenium concentrations in Corixidae and Chironomidae samples from the saline habitat ponds and reference sites, Ecosystem Monitoring Project, Salton Sea, California, spring 2008-fall 2008.... 53 


\section{Figures-Continued}

Figure 18. Relationships between natural log transformed selenium concentrations in Corixidae and Chironomidae samples from the saline habitat ponds 1 and 2 and reference sites, Ecosystem Monitoring Project, Salton Sea, California, spring 2008-fall 2008.

Figure 19. Principal component analysis ordination of elemental concentrations in Corixidae at the saline habitat ponds and reference sites, Ecosystem Monitoring Project, Salton Sea, California, fall 2006-fall 2008

Figure 20. Least-squares means (and 95-percent confidence intervals) for $p, p^{\prime}$ DDE concentrations in Corixidae samples collected from the saline habitat ponds and reference sites, Ecosystem Monitoring Project, Salton Sea, California, fall 2006-fall 2008

Figure 21. Least-squares means for selenium concentrations in fresh Black-necked Stilt eggs collected from the saline habitat ponds and reference sites for the Ecosystem Monitoring Project, Salton Sea, California, 2006 (A), 2007 (B), 2008 (C)

Figure 22. Average percentages (and 95-percent confidence intervals) of fresh Black-necked Stilt eggs collected from the saline habitat ponds and reference sites with selenium concentrations exceeding a toxicity threshold of $6.0 \mu \mathrm{g} / \mathrm{g}$, Ecosystem Monitoring Project, Salton Sea, California, 2006-08.

Figure 23. Spatially explicit selenium concentrations ( $\mu \mathrm{g} / \mathrm{g}$, dry weight) in fresh Black-necked Stilt eggs collected during the 2006, 2007, and 2008 nesting seasons, Ecosystem Monitoring Project, Salton Sea, California ....59

Figure 24. Average percentages (and 95\% confidence intervals) of fresh black-necked stilt eggs collected from the saline habitat ponds (SHP) and reference sites (Freshwater Marsh) containing an embryo malposition (red bars) or a fatal embryo malposition (orange bars), Ecosystem Monitoring Project, Salton Sea, CA, 2006-08.

Figure 25. Principal component analysis ordination of elemental concentrations in fresh Black-necked Stilt eggs collected at the saline habitat ponds and reference sites by site (A) and year (B), Ecosystem Monitoring Project, Salton Sea, California, 2006-08

Figure 26. Least-squares means (and 95\% confidence intervals) for $p, p$ ' DDE concentrations in fresh Black-necked Stilt eggs collected from the saline habitat ponds and reference sites, Ecosystem Monitoring Project, Salton Sea, California, 2006-08

Figure 27. Locations for radio-marked Black-necked Stilt chicks hatched at the saline habitat ponds detected alive during the 2006, 2007, and 2008 nesting seasons, Ecosystem Monitoring Project, Salton Sea, California .....

Figure 28. Estimated 95\% (home range) and 50\% (core area) utilization distributions for populations of radio-marked Black-necked Stilt chicks during the 2006, 2007, and 2008 nesting seasons, Ecosystem Monitoring Project, Salton Sea, California

Figure 29. Inter-pond movements for radio-marked black-necked stilt chicks hatched at the saline habitat ponds (SHP) during the 2006-08 nesting seasons, Ecosystem Monitoring Project, Salton Sea, California .....

Figure 30. Maximum distance and direction traveled from nest sites for Black-necked Stilt chicks radio-marked during the 2006, 2007, and 2008 nesting seasons, Ecosystem Monitoring Project, Salton Sea, California ....72

Figure 31. Measurements for water salinity (A), structural cover (B), and prey (Corixidae) abundance (C) in habitats occupied by radio-marked black-necked stilt chicks during the 2006, 2007, or 2008 nesting seasons, Ecosystem Monitoring Project, Salton Sea, California 


\section{Figures-Continued}

Figure 32. Maximum distance and direction traveled from nest sites for Black-necked Stilt chicks radio-marked during the 2006, 2007, and 2008 nesting seasons relative to average water salinity, Ecosystem Monitoring Project, Salton Sea, California.

Figure 33. Kaplan Meier survivorship functions and $95 \%$ confidence intervals to 21 days post-hatch for Black-necked Stilt chicks hatched at the saline habitat ponds and reference sites during the 2007-08 breeding seasons, Ecosystem Monitoring Project, Salton Sea, California

Figure 34. Effect of emigration from hatch site on hazard functions for Black-necked Stilt chicks hatched at the saline habitat ponds and reference sites during the 2007-08 breeding seasons, Ecosystem Monitoring Project, Salton Sea, California.

Figure 35. Relative frequencies for probable causes of mortality for all radio-marked post hatch Black-necked Stilt chicks, Ecosystem Monitoring Project, Salton Sea, California, 2006-08

\section{Tables}

Table 1. Geographical coordinates (decimal degrees, NAD83) for fixed water, sediment, and invertebrate sampling points, Ecosystem Monitoring Project, Salton Sea, California, 2006-2008

Table 2. Arithmetic mean values for water-quality measurements from surface-water samples collected from saline habitat ponds (SHP) and reference sites, Ecosystem Monitoring Project, Salton Sea, California, fall 2006-fall 2008

Table 3. Arithmetic mean values for water nutrient measurements from surface water samples collected from saline habitat ponds (SHP) and reference sites, Ecosystem Monitoring Project, Salton Sea, California, fall 2006-fall 2008

Table 4. Arithmetic mean values for sediment salinity measurements from sediment samples collected from saline habitat ponds (SHP) and reference sites, Ecosystem Monitoring Project, Salton Sea, California, spring 2006-fall 2008

Table 5. Arithmetic mean values for sediment composition measurements from sediment samples collected from saline habitat ponds (SHP) and reference sites, Ecosystem Monitoring Project, Salton Sea, California, spring 2006-fall 2008

Table 6. Percent relative abundance of macroinvertebrates collected from saline habitat ponds (SHP) and references sites, Ecosystem Monitoring Project, Salton Sea, California, fall 2006-fall 2008.

Table 7. Percent relative abundance of zooplankton collected by taxonomic class and location, Ecosystem Monitoring Project, Salton Sea, California, fall 2006-fall 2008.

Table 8. Arithmetic mean values for concentrations of trace elements $(\mu \mathrm{g} / \mathrm{L})$ in water samples collected from saline habitat ponds (SHP) and reference sites, Ecosystem Monitoring Project, Salton Sea, California, fall 2006-fall 2008

Table 9. Arithmetic mean values for concentrations of $p, p^{\prime}$ DDE (mg/L) in surface-water samples collected from saline habitat ponds (SHP) and reference sites, Ecosystem Monitoring Project, Salton Sea, California, fall 2006-fall 2008

Table 10. Arithmetic mean values for concentrations of trace elements ( $\mu \mathrm{g} / \mathrm{g}$, dry weight) in sediment samples collected from saline habitat ponds (SHP) and reference sites, Ecosystem Monitoring Project, Salton Sea, California, spring 2006-fall 2008

Table 11. Arithmetic mean values for concentrations of DDT compounds ( $\mu \mathrm{g} / \mathrm{g}$, dry weight) in sediment samples collected from saline habitat ponds (SHP) and reference sites, Ecosystem Monitoring Project, Salton Sea, California, spring 2006-fall 2008 


\section{Tables-Continued}

Table 12. Arithmetic mean concentrations of trace elements ( $\mu \mathrm{g} / \mathrm{g}$, dry weight) in invertebrate samples collected from saline habitat ponds (SHP) and reference sites, Ecosystem Monitoring Project, Salton Sea, California, fall 2006-fall 2008

Table 13. Arithmetic mean concentrations of DDT compounds ( $\mu \mathrm{g} / \mathrm{g}$, wet weight) in invertebrate samples collected from saline habitat ponds (SHP) and reference sites, Ecosystem Monitoring Project, Salton Sea, California, fall 2006-fall 2008

Table 14. Arithmetic mean concentrations of trace elements ( $\mu \mathrm{g} / \mathrm{g}$, dry weight) in fresh Black-necked Stilt eggs collected from saline habitat ponds (SHP) and reference sites, Ecosystem Monitoring Project, Salton Sea, California, May-July 2006-08

Table 15. Arithmetic mean concentrations of organochlorine compounds $(\mu \mathrm{g} / \mathrm{g}$, wet weight) in fresh Black-necked Stilt eggs collected from saline habitat ponds (SHP) and reference sites, Ecosystem Monitoring Project, Salton Sea, California, May-July 2006-08

Table 16. Estimates for $95 \%$ (home range) and $50 \%$ (core area) utilization distributions for radio marked Black-necked Stilt chicks during the 2006-08 breeding seasons, Ecosystem Monitoring Project, Salton Sea, California.

Table 17. Proportion of Black-necked Stilt chick locations occurring within a hatch pond and proportion of stilt chicks with more than one location in a non-hatch pond during the 2006-08 breeding seasons at the saline habitat ponds (SHP), Ecosystem Monitoring Project, Salton Sea, California

Table 18. Descriptive statistics for movements by post-hatch Black-necked Stilt chicks during the 2006-08 breeding seasons, Ecosystem Monitoring Project, Salton Sea, California.

Table 19. Survival rate estimates $(\mathrm{S}(\mathrm{t}))$ to 21 days post hatch for black-necked stilt chicks during the 2006-08 breeding seasons, Ecosystem Monitoring Project, Salton Sea, California

Table 20. Probable causes of death for radio-marked post hatch black-necked stilt chicks during the 2006-08 breeding seasons, Ecosystem Monitoring project, Salton Sea, California

Table 21. Values used to estimate ingested daily doses of selenium by Black-necked Stilts (DIBNST) and hazard quotients (HQ) for predictive ecological risk assessment; Ecosystem Monitoring Project, Salton Sea, California, fall 2006-fall 2008 


\section{Conversion Factors and Datum}

\section{Conversion Factors}

SI to US System

\begin{tabular}{lll}
\hline \multicolumn{1}{c}{ Multiply } & \multicolumn{1}{c}{ By } & \multicolumn{1}{c}{ To obtain } \\
\hline centimeter (cm) & 0.3937 & inch (in.) \\
millimeter (mm) & 0.03937 & inch (in.) \\
meter (m) & 3.281 & foot (ft) \\
kilometer (km) & 0.6214 & mile (mi) \\
hectare (ha) & 0.003861 & square mile (mi $\left.{ }^{2}\right)$ \\
microgram ( $\mu \mathrm{g})$ & $3.527 \mathrm{e}-08$ & ounce (oz) \\
milligram (mg) & $3.527 \mathrm{e}-05$ & ounce (oz) \\
gram (g) & 0.03527 & ounce (oz) \\
milliliters (mL) & 0.03382 & ounce, fluid (fl. oz) \\
liter (L) & 33.82 & ounce, fluid (fl. oz) \\
\hline
\end{tabular}

Temperature in degrees Celsius $\left({ }^{\circ} \mathrm{C}\right)$ may be converted to degrees Fahrenheit $\left({ }^{\circ} \mathrm{F}\right)$ as follows: ${ }^{\circ} \mathrm{F}=\left(1.8 x^{\circ} \mathrm{C}\right)+32$.

\section{Datum}

Horizontal coordinate information is referenced to the North American Datum of 1983 (NAD83). 


\section{Salton Sea Ecosystem Monitoring Project}

By A. Keith Miles, Mark A. Ricca, Anne Meckstroth, and Sarah E. Spring

\section{Executive Summary}

The Salton Sea is critically important for wintering and breeding waterbirds, but faces an uncertain future due to water delivery reductions imposed by the Interstate and Federal Quantification Settlement Agreement of 2003. The current preferred alternative for wetland restoration at the Salton Sea is saline habitat impoundments created to mitigate the anticipated loss of wetland habitat.

In 2006, a 50-hectare experimental complex that consisted of four inter-connected, shallow water saline habitat ponds (SHP) was constructed at the southeastern shoreline of the Salton Sea and flooded with blended waters from the Alamo River and Salton Sea. The present study evaluated ecological risks and benefits of the SHP concept prior to widespread restoration actions.

This study was designed to evaluate (1) baseline chemical, nutrient, and contaminant measures from physical and biological constituents, (2) aquatic invertebrate community structure and colonization patterns, and (3) productivity of and contaminant risks to nesting waterbirds at the SHP. These factors were evaluated and compared with those of nearby waterbird habitat, that is, reference sites.

A summary of findings include:

- Water salinity at the SHP was variable over time, averaging between 4-24 milliliters per liter (mL/L) in Pond 1, 9-30 mL/L in Pond 2, and 30-70 mL/L in Pond 3. Pond 4 was characterized by hypersaline conditions that averaged around 150 and $175 \mathrm{~mL} / \mathrm{L}$ from fall 2006 to fall 2007, and then more than $335 \mathrm{~mL} / \mathrm{L}$ after spring 2008. With the exception of salinity and chlorophyll in Pond 4, discrete measures of other water quality, chemistry (non-contaminant), or nutrient parameters were within acceptable limits for biological colonization, recruitment, and survival characteristic of variable salinity salt pond systems.

- Invertebrate community structure and diversity was most strongly coupled with water and sediment salinity. Invertebrate composition in Ponds 1 and 2 was characterized by variable abundance of Capitellidae, Amphipoda, and Corixidae. Conditions in Ponds 3 and 4 were most conducive to Corixidae (most ubiquitous invertebrate at Salton Sea wetlands) or Ephydridae, whereas conditions at most reference sites favored Chironomidae, Clitellata, Capitellidae, Amphipoda, Gastropoda, and Ephemeroptera. 
- Selenium was the most notable inorganic contaminants of concern. Selenium was statistically higher in sediment (1.8 micrograms per gram [ $\mu \mathrm{g} / \mathrm{g}]$, dry weight $[\mathrm{dw}]$ ) and Corixidae $(4.2 \mu \mathrm{g} / \mathrm{g}, \mathrm{dw})$ at the SHP than in sediment $(1.0 \mu \mathrm{g} / \mathrm{g} \mathrm{dw})$ or Corixidae $(2.2 \mu \mathrm{g} / \mathrm{g} \mathrm{dw})$ from reference sites. Selenium concentrations in water did not differ between the SHP (2.3 micrograms per liter $[\mu \mathrm{g} / \mathrm{L}])$ and reference sites $(2.2 \mu \mathrm{g} / \mathrm{L})$; however, the Alamo River had the highest average water selenium concentrations $(5.6 \mu \mathrm{g} / \mathrm{L})$ but the one of the lowest average sediment selenium concentrations $(0.5$ $\mu \mathrm{g} / \mathrm{g}$ ) of any site. Those reference sites sustained directly by Colorado River water (U.S. Fish and Wildlife Service Refuge's D-Pond and Hazard Complex) consistently had the lowest selenium among all sites. When accounting for inter-pond variation, selenium concentrations decreased over time in water and Corixidae across all SHP ponds. In contrast, selenium concentrations in sediments increased in Ponds 1 and 2 and decreased in Pond 4.

- Of the water samples taken from most sites (SHP Ponds 2 and 3 and reference D-Pond were the exceptions), 64-100 percent exceeded the $2.0 \mu \mathrm{g} / \mathrm{L}$ selenium toxicity threshold, whereas no sediment samples collected exceeded the $4.0 \mu \mathrm{g} / \mathrm{g}$ toxicity threshold. In Corixidae, 67-80 percent of samples from SHP Ponds 1, 2, and 3 exceeded the $4.0 \mu \mathrm{g} / \mathrm{g}$ toxicity threshold compared to less than or equal to 7 percent from SHP Pond 4 and reference sites.

- Corixidae significantly bioconcentrated selenium from water and sediment at both the SHP and reference sites. However, Corixidae bioconcentrated selenium from water at a steeper rate at the SHP. Selenium concentrations in Corixidae and Chironomidae were correlated at fresh- to- brackish water reference sites, but not at SHP Ponds 1 and 2.

- Distinct physical and biological patterns characterized differences in elements between SHP and reference sites. Boron and molybdenum concentrations in sediment and water samples and iron, aluminum, chromium, copper, and zinc concentrations in water and Corixidae were higher in SHP samples than those sampled at reference sites.

- $\quad$ Organochlorine compounds were rarely detected with the exception of $p, p$ ’ DDE. Concentrations of $p, p$ ' DDE in water samples were consistently less than two times the limit of detection at all sites. Sediment $p, p$ ' DDE concentrations were statistically lower at the SHP than those at reference sites. Within sites, concentrations of sediment $p, p^{\prime}$ DDE were lowest in Ponds 1,2 , and 4 ( $\left.\leq 0.02 \mu \mathrm{g} / \mathrm{g}\right)$ and highest at the Freshwater Marsh $(0.10 \mu \mathrm{g} / \mathrm{g})$ and Alamo River $(0.06 \mu \mathrm{g} / \mathrm{g})$. Concentrations of $p, p$ ' DDE were highest in Corixidae from Freshwater Marsh $(0.34 \mu \mathrm{g} / \mathrm{g} \mathrm{dw}, 0.06 \mu \mathrm{g} / \mathrm{g}$ wet weight [ww]) and Pond $2(0.16 \mu \mathrm{g} / \mathrm{g} \mathrm{dw} ; 0.03 \mu \mathrm{g} / \mathrm{g} w \mathrm{w})$. The reference D-Pond site consistently had the lowest sediment and Corixidae $p$, $p$ ' DDE concentrations. Concentrations of $p, p$ ' DDE did not exceed predicted threshold effects levels in any sediment or Corixidae sample.

- Selenium concentrations in fresh Black-necked Stilt (Himantopus mexicanus; hereafter stilt) eggs varied over time between groups. Concentrations of selenium in stilt eggs collected from the SHP were significantly higher than reference site eggs in 2006 and 2008 but did not differ between sites in 2007. 
- A large percentage of fresh stilt eggs collected from the SHP (47 percent) and reference sites Freshwater Marsh and Morton Bay (39 percent) exceeded the predicted $6.0 \mu \mathrm{g} / \mathrm{g}$ egg selenium toxicity threshold during the study. In contrast, no eggs collected from reference site D-Pond or Hazard exceeded the toxicity threshold. Selenium apparently did not affect embryo malpositioning that in turn affects hatchability.

- In contrast to patterns observed for water, sediment, and Corixidae, no distinct patterns in elemental composition or concentrations in stilt eggs occurred among sites, which suggested non-localized foraging prior to egg formation.

- Concentrations of $p, p$ ' DDE were significantly higher in stilt eggs collected from the SHP than those from reference sites in 2007 and 2008, but not in 2006. The percentage of stilt eggs exceeding the maximum fresh wet weight concentration reported from a previous south Salton Sea study ranged from 21 percent at D-Pond and Hazard reference sites to 44 percent at the SHP.

- Spatial use of the SHP by post-hatch stilt chicks was characterized by a low frequency of inter-pond movements, rapid dispersal out of the SHP within 3 days post-hatch, and large, non-random dispersal movements into surrounding freshwater habitats. In contrast, chicks hatched at freshwater reference sites moved shorter distances and were less likely to emigrate. These differences indicated that salinity or cryptic cover were important factors influencing chick-movements during the prefledgling life stage.

- Stilt chick survival to 21 days post-hatch was significantly higher for chicks hatched at reference sites (56 - 69 percent) than those hatched at the SHP (30 - 41 percent). Stilt chicks hatched at the SHP were about 2.5 times more likely to suffer mortality than chicks hatched at reference sites. Selenium concentrations determined from sibling eggs probably had no effect on survival. However, failure to emigrate from the SHP increased the probability of death by a factor of 9 .

- Predictive modeling indicated slightly elevated risk of selenium toxicity for stilts nesting at the SHP compared to reference sites.

\section{Problem Statement}

The Salton Sea is an inland terminal water body created in its present form during the early 1900s. The Salton Sea is one of the most important wetlands in the Western United States, supporting more than 400 species of wintering or breeding waterbirds (Shuford and others, 2002). However, recent water transfer agreements defined in the Quantification Settlement Agreement will reduce agricultural drainwater inflows into the Sea by an estimated 30\% by 2018 (California Department of Water Resources, 2007). Human-health and ecological hazards are predicted as inflow is reduced and the Salton Sea recedes. These hazards include reduced air quality from alkaline dust storms that result as the seabed dries, harmful or toxic salinity levels, and the loss of shoreline wetlands. The Salton Sea is listed as an impaired water body due to elements leached and concentrated by agricultural irrigation, a legacy of organochlorine pesticides, and nutrient-rich drainwater. Selenium, which is the most problematic of the elements, is essential for metabolic function but toxic at elevated doses (Ohlendorf, 1998). Current restoration planning alternatives for the Salton Sea are predicated on mitigating predicted hazards. 
The construction of wetland impoundments was proposed as a promising restoration alternative to offset the detrimental effects of reduced inflow (California Department of Water Resources, 2007). Wetland creation using direct deliveries of 'clean' Colorado River water is not a likely option for largescale restoration given the conditions imposed by the Quantification Settlement Agreement. Using agricultural drainwater from irrigated alkaline soils poses known selenium risks in California, exemplified most profoundly by the ecological disaster at Kesterson National Wildlife Refuge in the 1980s (Skorupa, 1998; Ohlendorf, 2002). Thus, a mix of water from the Salton Sea and drainwater was proposed as the best alternative for adequate water supply and to mitigate contaminant risks associated with using only fresh, agricultural drainwater. The elevated salinity of the blended water was expected to inhibit colonization of plants that may bioaccumulate selenium and to control mosquitoes.

The Bureau of Reclamation in cooperation with the U.S. Geological Survey created four interconnected shallow water saline habitat ponds (SHP) at the southeastern shoreline of the Salton Sea. Fresh (albeit agricultural-runoff) water from the Alamo River was mixed with saline water (approximately 44 parts per thousand or milliliters per liter [mL/L]) from the Salton Sea to inundate the ponds. Blended water entered Pond 1 at a target salinity of $20 \mathrm{~mL} / \mathrm{L}$ and flowed to each subsequent Ponds 2, 3, and 4 with increasing salinity due to evaporation. The small scale of the SHP provided an ideal setting to evaluate the feasibility of created wetlands under the prescribed water conditions. Physical and biological parameters were measured at the SHP in order to identify ecological risks or benefits that resource managers could evaluate prior to implementation of larger scale wetland restoration complexes. We used migratory waterbirds, in particular the common Black-necked Stilt (Himantopus mexicanus; hereafter stilt), as the focal endpoint for ecological assessment.

\section{Project Goals and Objectives}

We conducted an ecological assessment of the SHP and corresponding reference sites following completion of construction and initial flood-up in spring 2006. Sampling was timed to evaluate conditions for waterbirds during pre-breeding, breeding, and early wintering seasons. Our objectives were to determine:

1. Chemical, nutrient, and contaminant patterns in water and sediment.

2. Community structure and contaminants in avian prey, that is, common macroinvertebrates.

3. Contaminant concentration in stilt eggs and post-hatch spatial use and survival of stilt chicks.

4. Ecological risk assessment of adverse affects on avian populations inhabiting the SHP. 


\section{Project Description}

\subsection{Study Area}

The SHP is located at the southeastern shoreline of the Salton Sea, near the Davis and Shrimpf Road intersection, Imperial County, California (fig. 1). The approximate 50-ha complex is comprised of four, near equal-sized ponds separated by earthen levees. Intake pumps at the Garst and Shrimpf Road intersection drew water of about $30 \mathrm{~mL} / \mathrm{L}$ salinity from the Salton Sea and $\leq 2 \mathrm{~mL} / \mathrm{L}$ salinity from the Alamo River. The blended water was pumped about $2.5 \mathrm{~km}$ via an underground pipe into SHP Pond 1 where it then flowed to the remaining ponds through a series of gravity flow control gates. Flooding of Ponds 1 and 2 was initiated in March 2006 and all four ponds were flooded by September 2006 to average depths ranging from 0.2 to $0.4 \mathrm{~m}$.

Reference sites were established at the Alamo River, Salton Sea, Freshwater Marsh, and the D-Pond or Hazard complexes (Sonny Bono National Wildlife Refuge, U.S. Fish and Wildlife Service) to assess biological communities and contaminant risks characteristic of adjacent habitats (fig. 1). The Alamo River and Salton Sea sites represented habitats that provided source waters to the SHP. The Freshwater Marsh represented an expansive vegetated open wetland sustained by flow-through agricultural drainwater. The National Wildlife Refuge complexes are impounded wetlands sustained by water directly from the Colorado River that represented an assumed lowest contaminant risk. We initially investigated the D-Pond complex (hereafter D-Pond); however, it was drained prior to the end of the study and we substituted it with the Hazard complex (hereafter Hazard).

\subsection{Methods}

\subsubsection{Water, Sediment, and Invertebrate Sampling}

\subsubsection{Sampling Locations and Frequency}

We selected three random sampling points within each of the four SHP sites, and three sampling points at each of the four reference sites (table 1, fig. 1). At each sampling point, three subsamples were taken approximately $20-30 \mathrm{~m}$ apart and then composited as one sample per sampling point. Alamo River points were located at the SHP river intake pump, bridge at Sinclair Road, and Alamo River spit. The Salton Sea points were located near the intake pump, mudflat adjacent to the Alamo River spit, and Morton Bay, which had variable water intake from the Salton Sea or drainwater inflows. Points in Freshwater Marsh were near the terminus of a drainwater canal (the O Drain), the western end of Pound Road, and the marsh interior. Points in D-Pond were located in the northwestern, northeastern, and southeastern corners.

Each sampling point was spatially fixed using a Global Positioning System (GPS) (UTM Zone 11S, NAD83). Sediment samples were collected in March 2006 prior to flooding in order to obtain baseline contaminant and chemistry data. Water, sediment, and invertebrates were sampled on a biannual basis (spring = April, fall = October) beginning fall 2006 and ending fall 2008. All sample matrices were collected at all SHP points during the study. Fewer reference site points $(n=8)$ were sampled initially (fall 2006) but 12 reference points (3 per site) were sampled in spring 2007 through the remainder of the study. 


\subsubsection{Water Nutrients and Quality}

Surficial (top $10 \mathrm{~cm}$ ) water was collected at each sampling point to determine levels of nutrients and primary productivity. Water was collected in clean, $250 \mathrm{~mL}$ Nalgene ${ }^{\circledR}$ bottles, placed on ice, frozen within 8 hrs, and then sent within 1 week to the UC Davis Agricultural and Natural Resources (ANR) Laboratory for nutrient analysis. Samples were analyzed for nitrate $\left(\mathrm{NO}_{3}\right)$, ammonium $\left(\mathrm{NH}_{4}\right)$, phosphorous (soluble P), total dissolved solids (TDS). Concentrations of $\mathrm{NO}_{3}$ and $\mathrm{NH}_{4}$ were determined by flow injection analysis (ANR Method 847), soluble P by inductively coupled plasma atomic emission spectrometry (ICP-AES) (ANR Method 835), and TDS by oven drying and gravimetric analysis (ANR Method 870). Specific analytical details are provided at http://groups.ucanr.org/danranlab/Water_and_Waste_Water/. Total dissolved solids were quantified beginning spring 2007. To estimate primary productivity, water was collected at each sampling point in clean, acid (nitric) rinsed, $500 \mathrm{~mL}$ non photo-reactive Nalgene ${ }^{\circledR}$ bottles and immediately placed on ice. These samples were then express shipped to the UC Davis Limnology Lab for analysis of chlorophyll-a (Chl-a) within 24 hrs of collection. Water was filtered and the resulting extract analyzed for Chl-a using mass spectrometry. High salinity samples (for example, > $100 \mathrm{~mL} / \mathrm{L}$ ) were diluted prior to analysis.

Surficial water was further measured for salinity, conductivity, $\mathrm{pH}$, dissolved oxygen, oxidativereduction potential, and temperature in situ with a Hydrolab® Water Quality Analyzer. High salinity (>75 mL/L) samples were diluted with deionized water and salinity measured with a hand-held refractometer, and then back-calculated to the in situ concentration. All measuring devices were thoroughly rinsed with deionized water between points.

\subsubsection{Water Inorganic and Organic Contaminants}

Surficial water was analyzed for inorganic and organic contaminants at each sampling point within each site. Samples were collected in 1,000-mL Trace Clean ${ }^{\circledR}$ HDPE bottles for inorganic contaminants and in 1,000-mL Trace Clean ${ }^{\circledR}$ glass bottles for organic contaminants. Both sample types were placed on ice and then express shipped within 8 hours of collection to Battelle Marine Sciences Laboratory (BMSL) for inorganics and to Mississippi State Chemical Lab (MSCL) for organic contaminants.

Inorganic samples were acidified upon arrival at BMSL and analyzed for a maximum of 23 elements (listed in table 8) typically by inductively coupled plasma optical emissions spectroscopy (ICP-OES) or inductively coupled plasma-mass spectrometry (ICP-MS) depending on salinity interference and Quality Assurance/Quality Control (QA/QC) guidelines (appendix 1). Selenium (Se) was analyzed by either ICP-MS or hydride generation atomic absorption-flow injection atomic spectroscopy (HGAA-FIAS). Mercury (Hg) was analyzed by cold vapor atomic fluorescence (CVAF); Hg was determined only for samples collected in fall 2006 when all SHP ponds were flooded because of low or non-detectable levels. Limits of detection (LOD; appendix 2) varied according to dilutions required to analyze high salinity samples (appendix 3). Percent recoveries for certified reference materials (1640 or CASS-4) and matrix spikes averaged 102\% (standard deviation [SD] = 5\%) and $102 \%$ (SD = 10\%), respectively. Relative percent difference for duplicate samples averaged 7\% $(\mathrm{SD}=$ $11 \%$ ). All elemental concentrations in water are reported as micrograms per liter (or parts per billion, $\mu \mathrm{g} / \mathrm{L}])$. 
Organic samples were analyzed for a maximum of 22 organochlorine compounds (listed in table 15) by dual column gas chromatography - electron capture device (GC-ECD) (EPA Method 507 and 508). All organochlorine concentrations in water are reported as milligrams per liter (or parts per million, [mg/L]). The LOD was $<0.0001 \mathrm{mg} / \mathrm{L}$ for chlorinated pesticides, $<0.0005 \mathrm{mg} / \mathrm{L}$ for total PCBs, and $<0.001 \mathrm{mg} / \mathrm{L}$ for toxaphene (appendix 4).

\subsubsection{Sediment Chemistry and Composition}

Sediment samples were analyzed for alkalinity $(\mathrm{pH})$, salinity (carbonate $\left(\mathrm{CO}_{3}\right)$, bicarbonate $\left(\mathrm{HCO}_{3}\right)$, calcium $\left(\mathrm{Ca}^{+}\right)$, chloride $(\mathrm{Cl})$, magnesium $\left(\mathrm{Mg}^{+}\right)$, sodium $\left(\mathrm{Na}^{+}\right)$, estimated soluble salts $(\mathrm{EC})$, and composition (percent organic matter, percent organic carbon, and percent sand, clay, and silt). At each sampling point within sites, the top $5 \mathrm{~cm}$ of sediment from five subpoints spaced approximately 3 $\mathrm{m}$ apart was collected with a garden trowel, placed in a 3.8-L Ziploc ${ }^{\circledR}$ freezer bag, immediately placed on ice, refrigerated within 8 hrs of collection, and sent to the ANR Laboratory for analysis within 1 week of collection. Sampling instruments were thoroughly rinsed and cleaned between points. Using saturated paste extracts, sediment $\mathrm{pH}$ was determined with a $\mathrm{pH}$ meter (ANR Method 205), $\mathrm{CO}_{3}$ and $\mathrm{HCO}_{3}$ by acid titration (ANR Method 220), Cl by flow injection analysis (ANR Method 227), $\mathrm{Ca}^{+}$, $\mathrm{Mg}^{+}$by ICP-AES (ANR Method 235), $\mathrm{Na}^{+}$by emission spectrometry (ANR Method 235), and EC with a conductivity meter (ANR Method 215). Percent organic matter and carbon were determined by potassium dichromate reduction and spectrophotometric measurement (ANR Method 410), and percent sand, clay, silt by hydrometric measurement of suspended particles (ANR Method 470). Specific analytical details of ANR methods can be found at http://groups.ucanr.org/danranlab/Soil_Analysis/index.htm.

\subsubsection{Sediment Inorganic and Organic Contaminants}

At each sampling point within sites, cores from the top $5 \mathrm{~cm}$ of sediment from five subpoints spaced approximately $3 \mathrm{~m}$ apart were collected with a 2.5-cm PVC pipe for analysis of inorganic and organic contaminants. Samples were placed in 250-mL Trace Clean ${ }^{\circledR}$ HDPE jars for inorganic analyses and 250-mL Trace Clean ${ }^{\circledR}$ glass jars for organic analyses, immediately placed over ice, and frozen within 8 hrs of collection. Sampling instruments were thoroughly rinsed and cleaned between points.

Sediment samples were sent to BMSL for analysis of a maximum of 22 elements typically using ICP-OES or ICP-MS depending on salinity interference and QA/QC guidelines (appendix 5). All samples were analyzed for selenium by HGAA-FIAS except those from spring 2006 originally analyzed by ICP-OES. The spring 2006 samples were biased by an interfering wavelength ostensibly due to high salt content in most samples. Selenium concentrations in these samples were conservatively backcalculated using the upper 95\% confidence limits from the regression of selenium determined from ICPOES against selenium determined from HGAA-FIAS (adjusted selenium $=\exp -0.51+0.66^{\text {Se ICP-OES }}, r^{2}$ $=0.68)$. Mercury was analyzed by cold vapor atomic fluorescence (CVAF) and determined only for those samples collected in spring 2006 due to low or non-detectable levels. Limits of detection are provided in appendix 5. Percent recoveries for certified reference materials (NIST 2702 and 2704) averaged $94 \%(\mathrm{SD}=13 \%)$ and matrix spikes averaged 100\% (SD = 8\%). Relative percent difference for duplicate samples averaged $6 \%(\mathrm{SD}=11 \%)$. All elemental concentrations are reported as micrograms per gram (parts per million), dry weight. 
Sediment samples sent to MSCL were analyzed for 22 organochlorines using GC-ECD. Dry weight LODs were $0.002 \mu \mathrm{g} / \mathrm{g}$ for chlorinated pesticides, $0.01 \mu \mathrm{g} / \mathrm{g}$ for total PCBs, and $0.05 \mu \mathrm{g} / \mathrm{g}$ for toxaphene (appendix 6). Only DDT compounds ( $p, p^{\prime}$-DDD, -DDT, DDE; $o, p$ '-DDD, -DDT, -DDE) were quantified in spring 2008. All organochlorine concentrations in sediment are reported as micrograms per gram, dry weight.

\subsubsection{Invertebrate Community Structure}

To estimate community structure of littoral macroinvertebrates, we collected benthic samples from three subpoints spaced approximately $3 \mathrm{~m}$ apart with a standard Ekman dredge, and each pelagic sample consisted of five figure-8 sweeping motions with a D-ring net through the water column. Samples were washed through a 1.0-mm sieve, placed in plastic cups, preserved in $70 \% \mathrm{EtOH}$ dyed with rose-bengal, and sorted by USGS Davis Field Station laboratory personnel using dissecting scopes. Invertebrates were identified typically to taxonomic Family or the next best identifiable taxonomic classification and enumerated. We estimated taxonomic richness by tallying the total number of families that had at least 10 individuals per sample.

Zooplankton were sampled by pulling a hand-held net (150- $\mu$ m mesh size) through the water for 20 seconds at a constant speed at each sampling point. Using 70\% EtOH, netted particulates were rinsed into a $250 \mathrm{~mL}$ Nalgene ${ }^{\circledR}$ bottle, fixed with 4-5 drops of Lugol's solution, and stored in a dark place. Zooplankton samples were composited by site for each sampling period and sent to Dr. MaryAnn Tiffany (University of California, Riverside) for identification and quantification. A $3 \mathrm{~mL}$ subsample was rinsed with DI water to remove fixative using a 55- $\mu \mathrm{m}$ mesh cup. The sample was placed on a $3 \mathrm{~mL}$ counting slide to enumerate zooplankton. A larger subsample was taken and enumerated if few zooplankton were encountered. Equipment was washed and a new pipette used between samples to avoid cross contamination.

\subsubsection{Invertebrate Inorganic and Organic Contaminants}

We collected Corixidae (Family - water boatmen) for analysis of inorganic and organic contaminants. Corixidae were available in sufficient biomass ( $\geq 6 \mathrm{~g}$, blotted wet weight) at most sites due to their wide range of salinity tolerance (Menke, 1979). Only Ephydridae (Family - brine fly larvae) were present in the hyper-saline SHP Pond 4, and the Alamo River sites contained insufficient invertebrate biomass of any taxa probably due to fast water flow and high turbidity. We also collected epibenthic Chironomidae (Family - midge larvae) for selenium analysis from sites where present in spring and fall 2008 for comparison to the more vagile Corixidae. Invertebrates, collected at each point within sites using a D-ring net, were placed in 500-mL Trace Clean ${ }^{\circledR}$ glass jars filled with site water for at least 24 hrs to allow their guts to purge. These samples were then sorted, rinsed in deionized water, blotted, and frozen in 60-mL Trace Clean ${ }^{\circledR}$ jars.

Invertebrates were analyzed for a maximum of 21 elements by BMSL using ICP-OES or ICPMS depending on salinity interference and adherence to QA/QC guidelines (appendix 7). All selenium samples were analyzed by ICP-MS or HGAA-FIAS. Limits of detection are provided in appendix 7. Percent recoveries for certified reference materials (NIST 1566-b) averaged 103\% (SD = 39\%) and matrix spikes averaged 103\% (SD = 8\%). Relative percent difference for duplicate samples averaged $7 \%(\mathrm{SD}=16 \%)$. All elemental concentrations are reported as micrograms per gram, dry weight. 
Invertebrate samples were analyzed for 22 organochlorines by MSCL using GC-ECD. Wet weight LOD was $0.002 \mu \mathrm{g} / \mathrm{g}$ for chlorinated pesticides, $0.01 \mu \mathrm{g} / \mathrm{g}$ for total PCBs, and $0.05 \mu \mathrm{g} / \mathrm{g}$ for toxaphene (appendix 8). Only DDT compounds were quantified in spring 2008 because no other organochlorine compounds were detected during previous sampling periods. All organochlorine concentrations are reported as micrograms per gram on a wet or dry weight basis as indicated.

All invertebrate collections were authorized by scientific collecting permits (SC-4849) issued by the California Department of Fish and Game.

\subsubsection{Avian Contaminants and Ecology}

\subsubsection{Inorganic and Organic Contaminants in Black-Necked Stilt Eggs}

Black-necked Stilts (Himantopus mexicanus, hereafter stilts) rapidly colonized Ponds 1 and 2 at the SHP after initial flood-up in spring 2006 and were the most ubiquitous and abundant nesting waterbird throughout the study (Anderson, 2009). Stilts have been extensively studied as avian indicators of selenium toxicity (Ohlendorf, 2003; Skorupa, 1998), and we used stilt eggs as a representative endpoint of contaminant risk.

We collected viable eggs from stilt nests at the SHP during the nesting season (May-July) of 2006, 2007, and 2008 (fig. 2). Nest success at the SHP was determined in a related study (Anderson, 2009). We collected eggs along the shoreline or on islands in Ponds 1 and 2 (the only flooded ponds spring 2006) and at all four ponds in 2007 and 2008. Stilt eggs were collected at reference sites in proximity to established sampling points when possible but nest placement dictated where eggs were actually collected. Nests with eggs were found at D-Pond in 2006 and 2007, Morton Bay in 2007, Hazard in 2007 and 2008, and Freshwater Marsh in all years. All nests were marked, geo-referenced with GPS, and then the eggs floated in a container of fresh water to estimate laying date (Westerskov, 1950). We then selected one egg at random from a nest, ideally at 7-12 days of incubation when possible. The total number collected annually from each site was governed by the scientific collection permits. We attempted to spread the number of nests targeted for egg collection evenly among sites and across the nesting season. Eggs were refrigerated within 2 hrs of collection.

Whole egg mass was measured on a digital scale to the nearest $0.1 \mathrm{~g}$, and length and breadth measured with digital calipers to the nearest $0.01 \mathrm{~cm}$. The blunt end of each egg was then opened with clean recurved surgical scissors and the contents emptied into Trace Clean ${ }^{\circledR} 60-\mathrm{mL}$ jars and frozen until analyses. To evaluate embryonic abnormalities that are often indicative of selenium toxicity (Ohlendorf, 1998), eggs containing later stage embryos ( $\geq 18$ days old) were examined for mal-positionings that deter hatchability, and all embryos 12 days old were examined for teratogenic defects (for example, missing or poorly developed eyes and appendages). Malposition classes were: head between thighs (MP-I), head in small end of egg (MP-II), head under left wing (MP-III), beak not directed toward air cell (MP-IV), feet over head (MP-V), and beak over right wing (MP-VI); malposition classes MP-I, III, and V generally are considered most fatal (Hutt, 1929; Wilson and others, 2003). 
Egg samples were shipped to MSCL, homogenized, and an aliquot analyzed for 22 organochlorines using GC-ECD. The LOD was $0.002 \mu \mathrm{g} / \mathrm{g}$ for chlorinated pesticides, $0.01 \mu \mathrm{g} / \mathrm{g}$ for total PCBs, and $0.05 \mu \mathrm{g} / \mathrm{L}$ for toxaphene (appendix 9). Egg organochlorine concentrations are reported as micrograms per gram, wet or fresh wet weight. We used the following formula to convert wet weight to fresh wet weight (FWW):

FWW = wet weight concentration* [(original whole egg mass/( $0.000467 *($ egg length*egg width2)*1.1)] (Hoyt, 1979; Evers and others, 2003; C.A. Eagles-Smith, unpublished USGS data, October 2009).

An aliquot of homogenate from each egg sample was shipped from MSCL to BMSL, where it was freeze-dried and analyzed for a maximum of 21 elements typically using ICP-OES or ICP-MS depending on QA/QC guidelines (appendix 10). All selenium samples were analyzed using ICP-MS or HGAA-FIAS. The LOD is provided in appendix 10. Percent recoveries for certified reference materials (NIST 1566-b) averaged 97\% (SD = 12\%) and matrix spikes averaged 105\% (SD = 5\%). Relative percent difference for duplicate samples averaged 12\% (SD = 17\%). Egg elemental concentrations are reported as micrograms per gram, dry weight.

Egg collections were authorized by scientific collection permits issued by the U.S. Fish and Wildlife Service's Region 1 Migratory Bird Office (MB-121218) and the California Department of Fish and Game (SC-4849).

\subsubsection{Post-Hatch Movement and Survival}

\section{Chick Radio-Marking andlTracking}

We evaluated spatial use and survival patterns of post-hatch stilt chicks as an additional measure of ecological risks and benefits of the SHP relative to reference sites. Chicks were marked in Ponds 1 and 2 in 2006 (Ponds 3 and 4 were dry) and at all SHP ponds in the 2007 and 2008 nesting seasons. Chicks were found and marked only at Hazard in 2007 and 2008, and Freshwater Marsh in 2008 probably due to high rates of nest predation outside of the SHP (protected by an electric fence).

We visited nests near their hatch date that was estimated through nest monitoring and marked one chick less than 24 hours post-hatch per brood. In 2007 and 2008, we targeted nests where an egg was collected so that we could correlate egg contaminant concentrations to the marked chick. The selected chick was weighed to the nearest $0.5 \mathrm{~g}$ with a hanging Pensola ${ }^{\circledR}$ scale, and then the length of wing chord, tarsus, and culmen measured to the nearest $0.1 \mathrm{~cm}$ with digital calipers. Chick age was estimated based on weight and the presence of an egg tooth. A 0.8-g radio transmitter (model BD-2T, Holohil Systems Ltd., Ontario, Canada) was then attached between the chick's scapulars using subcutaneous dissolvable sutures. The chick was assessed for mobility and condition and then returned to its nest. To minimize stress, no chick was processed once the air temperature reached $35^{\circ} \mathrm{C}$. Radios transmitted for an average of 18 days, had a maximum audible range of $1 \mathrm{~km}$, and were equipped with mortality sensors that transmitted a low pulse rate when chick body temperatures decreased below normal levels. Radio marking was authorized under USGS Bird Banding Lab Permit Number 22911. 
Marked chicks were located during morning (0500-1200) and evening (1900-2200) hours using a hand-held telemetry receiver attached to a 3-element Yagi antennae. Most locations (ca. >85\%) were obtained by direct visual observation or circling within less than $50 \mathrm{~m}$ of the chick, and recorded with GPS. We used Locate 3.18 (Pacer Computing, Tatamagouche, NS, Canada) to estimate the remaining locations from triangulated bearings. We monitored radio signal pulse rates within an hour of sunrise when ambient temperatures were lowest to assess survival on days when locations were not obtained. Thus, no more than 48 hrs elapsed between searches for radio signals. All dead radio-marked chicks were recovered, labeled, and the cause of death determined if possible, and frozen.

\section{Spatial Use Estimation}

We used fixed kernel estimators with bandwidths calculated from least-squares cross validation to calculate 95\% (home range) and 50\% utilization distributions (core area) using the Animal Movement Extension for ArcView 3.2 (Hooge and Eichenlaub, 1997). The utilization distributions represented the probability that chicks occurred in a given area during a specified time, and were calculated separately for the marked populations of chicks hatched in the SHP, Hazard, and Freshwater Marsh for each year.

For each chick, we calculated an index of dispersal: the distance and direction from nest site to the location farthest from nest site that the chick was detected as alive. We also calculated an index of site tenacity: average distance traveled between successive locations among sites. To specifically measure space use within the SHP, we calculated the proportion of locations that occurred within a chick's natal pond, and the proportion of chicks that moved between ponds for chicks hatched during 2007 and 2008. We defined emigration as permanent chick movement out of the SHP ponds or when chicks from reference sites crossed a major obstacle (for example, a steep-sided canal). Three days was the median number of days to emigration at all sites, thus we assumed that all chicks that survived at least 3 days post-hatch were capable of emigrating in this analysis.

\section{Survival Estimation}

Maximum survival estimations for stilt chicks corresponded with the maximum life of the radios, that is, 21 days post-hatch. We excluded any chicks that died within 1 day of hatching and showed no obvious signs of trauma from all survival analyses in order to minimize capture effects bias. We estimated survival and chick fates under two scenarios due to a high incidence of chicks that disappeared before 21 days. Under scenario 1, chicks that survived more than 18 days (average transmitter life) or whose signals were failing (that is, signal pulse rate doubled or audible distance range decreased to less than $100 \mathrm{~m}$ ) were right censored, that is, it was assumed that the transmitter failed but that the chick survived (Lawless, 2003). We also right censored chicks whose transmitters were recovered in questionable locations (for example, canal bottoms) within 4 days post hatch. Under scenario 2, chicks that disappeared in less than 18 days with no prior warning signal or transmitters that were recovered under questionable circumstances were assumed dead. This provided liberal (scenario 1) and conservative (scenario 2) survival estimates due to uncertainty in assigning known fates for all marked chicks.

Survival rates for populations of marked chicks at the SHP and reference sites were estimated with the Kaplan-Meier method (Pollack and others, 1989) using PROC LIFETEST in SAS (v8.12 statistical software, SAS Institute, Cary, NC). We used SAS PROC PHREG to estimate hazard or risk ratios (that is, the odds of an animal dying at a particular time). 


\section{Habitat Measurements}

We measured water salinity and macroinvertebrate abundance as additional variables that might explain variation in chick spatial use and survival. Sampling occurred at a minimum of three locations and two time intervals in each SHP pond and reference site per year. Salinity was measured with a hand-held refractometer. Pelagic invertebrate samples were collected, preserved, and enumerated as described in section 4.2.1.6. We report the average number of Corixidae per site as an index of food availability.

In 2008, we measured vertical and horizontal hiding cover at the SHP and reference sites as an additional habitat component. Vertical cover (which included relief such as rocks and slope) was estimated with a modified 2-m tall Robel pole (Griffith and Youtie, 1988), horizontal cover was measured in a $1-\mathrm{m}^{2}$ plot using Daubenmire coverage classes. Twenty-three transects (about $300 \mathrm{~m}$ in length) were randomly placed within sites and cover was estimated every $10 \mathrm{~m}$.

\subsubsection{Statistical Analyses}

\subsubsection{Contaminant Concentrations}

For water, sediment, or invertebrate sample matrices, we used mixed-effects nested analysis of variance (ANOVA) to test for differences in selenium and $p, p$ ' DDE concentrations between groups (SHP, reference), sites (nested within groups), and time. Because fewer reference sites were sampled for sediments prior to fall 2006 or water prior to spring 2007, statistical comparisons of these sample types were made from these time intervals forward to maintain model balance in the number of sites between the SHP and reference groups. We conducted a mixed-effect ANOVA to test for differences among SHP ponds over time for all sampling periods to further elucidate spatial and temporal patterns within the SHP. Reported results were for main effects models unless interactions were significant. We report $t$-statistics for time parameter coefficients to infer positive or negative relationships. Models were constructed using SAS PROC Mixed, whereby the sampling point was treated as a random effect. Differences between least-square means were compared with Tukey Kramer adjusted multiple comparison tests. Contaminant concentrations were $\log _{\mathrm{e}}$ transformed prior to all statistical analyses. Organochlorine concentrations in invertebrates were tested on a dry weight basis.

We examined differences between groups in potential uptake of selenium from water and sediment by Corixidae and Chironomidae using mixed effects analysis of covariance (ANCOVA). Sites were treated as a random variable and sampling point treated as a random repeated effect to control for time. Only data from spring 2007 onward were included in the analysis to maintain model balance. Relationships between selenium concentrations in Corixidae and Chironomidae from paired sampling points were tested with mixed effects ANCOVA using the same random effects. These data represented samples from fresh to brackish water sites where Chironomidae were present during spring and fall 2008.

We used nested ANOVA to test for differences in elemental (dry weight) and organochlorine (fresh wet weight) concentrations in stilt eggs between groups and sites. Separate models were run for each year (2006, 2007, and 2008) because not all sites were sampled each year. 
To determine selenium effects on egg hatchability, we used logistic regression (SAS PROC Logistic) to model the effect of egg selenium concentrations (dry weight) on the likelihood of total embryo malpositions and fatal embryo malpositions. Site effects were controlled by creating a dummy variable for the SHP and pooled Freshwater Marsh/Morton Bay sites. No egg from D-Pond/Hazard contained a malpositioned embryo $\geq 18$ days old. Eggs from all years were pooled because too few eggs from particular sites contained malpositions within each year. The pooled Freshwater Marsh/Morton Bay sites represented habitats sustained by agricultural drainwater variably mixed with Salton Sea water.

We used principal components analysis using PC-ORD (McCune and Mefford, 2006) to reduce elemental data to highly correlated sets to elucidate spatial and temporal patterns for each sample matrix. All concentrations were $\log _{\mathrm{e}}$ transformed prior to all statistical analyses. Elements that occurred with an overall detection frequency of $<50 \%$ for a particular sample matrix and outliers (SD $\geq 2.0$ ) were excluded from the ordination to minimize the influence of rarely detected elements. The final number of axes to retain was determined by a combination of axis eigenvalues ( $>1.0$ to retain), comparisons to broken-stick values (eigenvalue $>$ broken-stick), and randomization tests $(P<0.05)$ (McCune and Grace, 2002). We used joint plots and correlation coefficients $\left(r^{2}>0.3\right)$ to identify gradients of elemental concentrations driving axis loadings, and to determine associations with relativized water and sediment physical measurements (for example, water quality and sediment composition).

\subsubsection{Invertebrate Community Structure}

We used non-metric multidimensional scaling (NMS) (Kruskal, 1964) using PC-ORD (McCune and Mefford, 2006) to identify patterns of macroinvertebrate community structure among groups, sites, and time. We grouped common taxa by taxonomic Family, which included Capitellidae, Chironomidae, Corixidae, Daphniidae, Ephydridae, and Nereidae. Uncommon (that is $<5 \%$ of all samples at a specific time interval) taxa were grouped into higher taxonomic classifications of Order, Class, or Phylum. These groups included: Amphipoda (Corophiidae, Gammaridae), Arachnida (Hydracarina, unknown Arachnida), Clitellata (Tubificidae, Naididae, unknown Haplotaxida, unknown Oligochaeta), Coleoptera (Carabidae, Curculionidae, Dytiscidae, Elmidae, Hydrophilidae, Staphylinidae), other Diptera (Culicidae, Ceratopogonidae, Dolichopodidae, Empididae, Muscidae, Tipulidae, unknown Diptera), Ephemeroptera (Baetidae, Caenidae, unknown Ephemeroptera), Gastropoda (Assimineidae, Physidae, Rissoidae, unknown Gastropoda), other Hemiptera (Aphididae, Cicadellidae, Lygaeidae, Notonectidae unknown Hempiptera), Maxillopoda (unknown Cirripedia, unknown Copepoda), Nematoda (unknown Nematoda), Ostracoda (Cytherideidae, Sarsiellidae, unknown Ostracoda), and Polychaeta (unknown Polychaeta). Rare ( $<5 \%$ of all samples collected during the study) taxa were excluded from the analysis to minimize the effect of rare taxa on the ordination (McCune and Grace, 2002). We applied Beals smoothing, which creates a favorability index of each sample for each taxa, to relieve the 'zero truncation problem' common among community data sets, and selected the Sorensen proportion coefficient as the distance measure (McCune and Grace, 2002). Goodness of fit of the final NMS model was achieved when stress criterion fell below $15 \%$. We used joint plots and correlation coefficients to identify gradients of taxa composition driving axis loadings, and to determine associations with relativized water quality, water nutrient, sediment composition, and sediment salinity measurements. 


\section{Stilt Spatial Use}

We used ANCOVA to test for differences in maximum distance traveled from nest site and average distance traveled between successive locations among hatch groups and years. Julian hatch date was included as a covariate because of asynchrony in hatching across sites. Response variables were strongly right-skewed and therefore square root transformed to meet normality assumptions. Within groups and years, we used Rayleigh's $Z$ to determine if angles of movement for maximum distance traveled from nests were random (Zar, 1996). All statistical tests for movement were restricted to chicks capable of emigrating.

\section{Stilt Survival}

Statistical tests of survival were conducted for chicks hatched in 2007 and 2008 (few chicks hatched at the SHP in 2006 when flooding initiated). Differences between the shapes of survivorship curves between groups (SHP vs. Reference) and years were tested with the log rank test (Allison, 1995). We used three sets of Cox-proportional hazard models to test covariate effects on estimated hazard ratios, that is, the odds of mortality occurring at a given point in time (Allison, 1995). The Cox model assumes that covariates multiply hazard or increase the chance of mortality. For Set 1, we first constructed time dependent covariates for group and year to test for violations of the proportional hazards assumption. If proportionality was met, Set 1 covariates included Julian hatch date, morphometrically adjusted body size at hatching (heretofore body size), year, and group for all chicks. Set 2 included the egg selenium concentration as an additional covariate for the subset of chicks where a sibling egg was collected. Set 3 only included chicks capable of emigrating $\geq 3$ days post-hatch) to determine if chick emigration influenced the hazard ratio. For Sets 2 and 3, group and year were not of direct interest and were treated as strata variables to control for possible spatial and temporal effects. Low sample size precluded testing differences in survival within groups (SHP or reference) but patterns are qualitatively described.

\subsubsection{Predictive Ecological Risk Assessment (PERA)}

The PERA is a process of comparing measured concentrations of toxic chemicals with contaminant-specific toxicity data to derive levels that are protective of biota. The result of this process is a hazard quotient (HQ) that is generated for each species of concern. More detail about this assessment is provided in appendix 11. For the Salton Sea Ecosystem Monitoring Project, the PERA is used to evaluate the potential risk of selenium on stilts. The stilt was selected as the assessment endpoint because it is an upper-trophic-level species susceptible to bioaccumulation or biomagnification and was directly tied to the structure and function of the ecosystem at risk, that is, the SHP Ponds. Baseline risk assessment of this indicator species provides measurable guidance for the degree of recovery necessary to reduce risk, and is a means of determining the rate of recovery as mitigation actions are enacted. 
As secondary consumers, stilts represent exposure routes involving potential bioaccumulation of contaminants and food-web transfer. Thus, ingestion of contaminated aquatic invertebrates is the primary route of exposure with incidental ingestion of sediments. The exposure model for ingestion is

$\mathrm{Di}_{\mathrm{BNST}}=\left\{\left[\left(\mathrm{C}_{\mathrm{i}} \times \mathrm{R}_{\mathrm{d}} \times \mathrm{F}_{\mathrm{i}}\right)+\left(\mathrm{EC}_{\mathrm{s}} \times \mathrm{R}_{\mathrm{d}} \times \mathrm{F}_{\mathrm{s}}\right)\right] \div \mathrm{BW}_{\mathrm{BNST}}\right\} \times \mathrm{T}_{\mathrm{f}}$

Where

$\mathrm{Di}_{\mathrm{BNST}} \quad=\quad$ daily dosage from ingestion

$\mathrm{C}_{\mathrm{i}} \quad=\quad$ concentrations of potentially toxic chemicals in invertebrates

$\mathrm{R}_{\mathrm{d}} \quad=\quad$ intake rate for Black-necked Stilt

$\mathrm{F}_{\mathrm{i}} \quad=\quad$ fraction of invertebrates in Black-necked Stilt diet

$\mathrm{EC}_{\mathrm{s}} \quad=\quad$ concentrations of potentially toxic chemicals in sediment

$\mathrm{F}_{\mathrm{S}} \quad=\quad$ fraction of soil in Black-necked Stilt diet

$\mathrm{BW}_{\mathrm{BNST}}=$ mean body weight of Black-necked Stilt

$\mathrm{T}_{\mathrm{f}} \quad=\quad$ fractional intake, or fraction of time spent in contact with contaminated sediments

A hazard Quotient (HQ) is the ratio of the estimated exposure to the toxicity reference values (TRV, U.S. Environmental Protection Agency, 2009; Heinz and others, 1989):

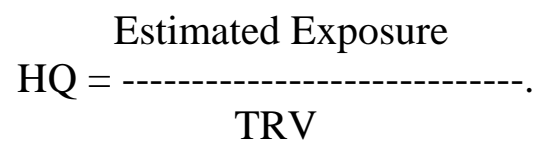

The implicit assumption in characterizing risk is that, based on the estimated potential effects on individuals, inferences or extrapolations can be made to assessment endpoints or population-level effects. Low HQs are derived using no observable adverse effects levels (NOAEL) and High HQs are derived using low observable adverse effects levels (LOAEL). Chronic low HQs that exceed 1.0 suggest that adverse effects are possible to sensitive individuals, while chronic high HQs that exceed 1.0 suggest that adverse effects to most individuals are likely. 


\subsection{Results and Discussion}

\subsubsection{Water Quality and Nutrients}

Average water-quality measurements of the SHP and reference sites are provided in table 2 . Salinity was the most notable of the parameters that varied spatially and temporally in the SHP. Average salinity concentrations in SHP Ponds 1, 2, and 3, were lower in the fall seasons of 2006 and 2007 than in the subsequent spring seasons of 2007 and 2008 (fig. 3). By fall 2008, the pattern of salinity concentrations was more similar to the previous spring 2008 in the SHP. Salinity concentrations were expectedly lower in Ponds 1 (intake) and 2 than in Ponds 3 and 4 (terminal pond). Measures of Pond 4 in spring 2007 indicated hypersalinity that increased from 174 to $398 \mathrm{~mL} / \mathrm{L}$ by fall 2008 . Salinity in the Salton Sea ranged from 23 to $40 \mathrm{~mL} / \mathrm{L}$ prior to spring 2008, but then decreased to greater than $8.4 \mathrm{~mL} / \mathrm{L}$ thereafter during the study. Salinity in the Alamo River, Freshwater Marsh, and D-Pond reference sites was relatively constant $(\leq 6 \mathrm{~mL} / \mathrm{L}$ ). Conductivity also varied spatially and temporally, but was highly correlated to salinity.

Concentrations of Chl-a, an estimate of primary productivity, varied spatially and temporally (fig. 4). Average Chl-a concentrations were consistently highest ( $>350 \mu \mathrm{g} / \mathrm{L})$ at Pond 4 and lowest $(<25$ $\mu \mathrm{g} / \mathrm{L})$ at the Alamo River. At the SHP, average Chl-a concentrations at Pond 1 were highest $(136 \mu \mathrm{g} / \mathrm{L})$ in fall 2006 and then $<59 \mu \mathrm{g} / \mathrm{L}$ thereafter. Chl-a concentrations in pond 2 were $<66 \mu \mathrm{g} / \mathrm{L}$ across all intervals until fall $2008(158 \mu \mathrm{g} / \mathrm{L})$. At the reference sites, average concentrations were consistently high at the Salton Sea and D-Pond sites ( $\geq 90 \mu \mathrm{g} / \mathrm{L}$ ). Notably D-Pond was dry in fall 2008, and the subsequent sample collected at the Hazard complex was substantially lower than any measures for DPond. With some temporal exceptions, concentrations of Chl-a in Ponds 1, 2, 3, and Freshwater Marsh were mostly similar to those reported for productive salt ponds in the north San Francisco Bay (about 25-52 $\mu \mathrm{g} / \mathrm{L}$ ) (Takekawa and others, 2006). In contrast, Chl-a concentrations at Pond 4, Salton Sea, and D-Pond exhibited reflected higher primary productivity relative to north San Francisco Bay.

Water nutrient measurements were characteristically low or within normal concentrations at most sites over time (table 3). Average ammonium concentrations were $\leq 2 \mathrm{mg} / \mathrm{L}$ at all sites except for Pond 4 and the Salton Sea sites in fall 2006. Average concentrations of nitrate and phosphorous at most SHP and reference sites were $\leq 3.5 \mathrm{mg} / \mathrm{L}$. The notable exception was the Alamo River sites where nitrate concentrations ranged from 4.2 to $6.9 \mathrm{mg} / \mathrm{L}$. With the possible exception of the Alamo River, nutrient concentrations at the SHP and reference sites were well below the $10 \mathrm{mg} / \mathrm{L}$ threshold associated with anaerobic waterbodies (Peng and others, 2008). Total dissolved solids in Pond 4 (170,730-266,970 $\mathrm{mg} / \mathrm{L}$ ) were 3-200 times higher than concentrations measured at all other sites.

\subsubsection{Sediment Chemistry and Composition}

Sediment salinity and composition measurements are summarized in tables 4 and 5 , respectively. Sediments in the closed SHP pond system expectedly had higher concentrations of magnesium, sodium, calcium, chloride and estimated soluble salts than detected at most (Salton Sea was the exception) reference sites. Low concentrations of these salts at most reference sites were indicative of fresh to brackish open or flow through systems. Organic carbon concentrations were low to moderate at all SHP and reference ponds (0.3-2.0\%). Increased organic carbon content in sediments is often associated with reduced invertebrate abundances as it accompanies low dissolved oxygen and elevated sulfide, ammonia, and contaminant concentrations (Thompson and Lowe, 2004). 


\subsubsection{Invertebrate Community Structure}

Abundance of macroinvertebrate taxa varied spatially and temporally (table 6, fig. 5). Chironomidae, Corophiidae, Capitellidae, and Ostracoda were absent or infrequent in Pond 1 in fall 2006 and then fluctuated as much as 20 -fold during subsequent sampling intervals. Corixidae generally were most abundant ( $>1,500$ individuals/sample) at Pond 3 and the Salton Sea, but were detected in Pond 4 only in fall 2006. At reference sites, Corixidae were most abundant ( $>4,000$ individuals/sample) at the Salton Sea in spring and fall 2008. Tubificidae were most common at the Freshwater Marsh and D-Pond in spring 2008, and were detected only in Pond 2 at the SHP. Capitellidae generally were most abundant at Pond 2, and were detected only at abundances $\geq 200$ individuals at Pond 3 in spring 2008 and Salton Sea in fall 2006. Corophiidae were not detected at any reference site. Ostracoda were most frequently detected at Ponds 1 and 2, and the Salton Sea.

Family richness in Ponds 1 and 2 more than doubled from fall 2006 to spring 2008 before decreasing to values near baseline richness (that is, fall 2006 richness values) in fall 2008 (fig. 6). Ponds 3 and 4 generally had the lowest Family richness $(n \leq 3)$ during the study, with the exception of Pond 3 $(n=5)$ during spring 2008. Family richness at the reference sites varied over time, with the highest richness at Freshwater Marsh in spring $2008(n=11)$ and the lowest richness at the Alamo River $(n=2)$ in fall 2006 and fall 2007.

Ninety-one percent of the cumulative variation in macroinvertebrate community structure was explained by a two-dimensional NMS solution (fig. 7). Axis 1 (72\%) was most negatively correlated $\left(r^{2} \geq 0.57\right)$ with Corixidae and Ephydridae $\left(r^{2} \geq 0.53\right)$, and most positively correlated with Chironomidae and Clitellata $\left(r^{2}=0.69\right)$. Axis $2(19 \%)$ was most negatively correlated with Capitellidae and Amphipoda $\left(r^{2} \geq 0.52\right)$ and most positively correlated with Gastropoda and Ephemeroptera $\left(r^{2} \geq 0.49\right)$. Samples clearly separated by group and site to a lesser degree in the ordination space. Samples from Ponds 3 and 4 were associated with high favorability for Corixidae and Ephydridae on the left side of Axis 1, whereas samples from most reference sites were associated high favorability for Chironomidae and Clitellata on the right-hand side of Axis 1 (fig. 7). The Freshwater Marsh, D-Pond/Hazard, and (to a lesser degree) Salton Sea samples located in the upper right-hand quadrant of the ordination space were associated the most diverse taxonomic assemblage of invertebrates. Samples from Ponds 1 and 2, and some Alamo River sites were associated with high favorability of Capitellidae and Amphipoda along the lower end of Axis 2. Although absolute invertebrate abundance was variable over time (table 6, fig. 5), relative favorability changed little over time as evidenced by the consistent separation of groups and sites in the ordination space. A gradient of water salinity, sediment salinity, and total dissolved solids was best associated with invertebrate community structure along Axis $1\left(r^{2} \geq 0.36\right)$, indicating that increasing salinity and turbidity increased favorability for Corixidae and Ephydridae, and decreased favorability for the remaining salt intolerant taxa (fig. 7). All other water and sediment measurements were weakly correlated with Axis $1\left(r^{2} \leq 0.19\right)$ and Axis $2\left(r^{2} \leq 0.09\right)$.

We identified 12 different taxonomic groups of zooplankton, most at the level of Class and Order. Copepoda was the most abundant and diverse Class with four Orders identified. Three different Classes of zooplankton were identified in the SHP ponds and seven different Classes were identified in the reference ponds. The relative abundance of zooplankton between seasons and ponds is presented in table 7. 


\subsubsection{Inorganic and Organochlorine Contaminants}

\subsubsection{Water Contaminants}

\section{Selenium}

Selenium was detected in all water samples (table 8). Concentrations of selenium in water did not differ significantly between groups (lsmeans: SHP $=2.34 \mu \mathrm{g} / \mathrm{L}$, reference $=2.15 \mu \mathrm{g} / \mathrm{L} ; F=2.3, P=$ $0.2)$, and did not increase over time beginning in spring 2007 across both groups $(F=0.3, P=0.6)$. However, sites nested within groups differed significantly $(F=45.5, P<0.0001)$. Selenium concentrations were highest in the Alamo River, lowest in D-Pond/Hazard (followed by Ponds 2 and 3), and did not differ among Pond 4, Freshwater Marsh, Salton Sea, or Pond 1 (fig. 8). After accounting for inter-pond variation, water selenium concentrations in SHP ponds as a whole decreased linearly over time $\left(t_{[60]}=-2.2, P=0.02\right)$.

The suggested toxicity threshold for selenium in water is $2.0 \mu \mathrm{g} / \mathrm{L}$ (U.S. Department of the Interior, 1998; Hamilton, 2004). Selenium concentrations greater than 1-2 $\mu \mathrm{g} / \mathrm{L}$ are considered elevated above typical background concentrations. All water samples from Pond 4 and the Alamo River, and 64$67 \%$ of samples from Pond 1, Salton Sea, and Freshwater Marsh across all time periods exceeded the toxicity threshold (fig. 9). No samples from D-Pond exceed the toxicity threshold whereas $27 \%$ of these samples exceeded background concentrations. Notably, Pond 2 had a low percentage of samples exceeding the toxicity threshold (20\%) and background concentration (33\%). The percentage of samples in Pond 3 was intermediate, with 33\% exceeding the toxicity threshold and 67\% exceeding the background concentration. In contrast, 100\% of samples from the Alamo River exceeded the U.S. Environmental Protection Agency's (1987) water-quality criteria of $5.0 \mu \mathrm{g} / \mathrm{L}$ for the protection of aquatic life.

\section{Elemental Concentrations and Compositional Patterns}

Elemental concentrations in water are provided in table 8. Arsenic concentrations in water averaged from less than the limit of detection (LOD) - $229.7 \mu \mathrm{g} / \mathrm{L}$ during the study. However, the highly elevated concentrations of arsenic in Pond 4 and Salton Sea samples in fall 2006 and 2007 were suspected as sampling or laboratory artifacts because these concentrations were not observed at other sampling intervals or locations. Excluding these samples, all average arsenic concentrations were less than the $48 \mu \mathrm{g} / \mathrm{L}$ no effect and $190 \mu \mathrm{g} / \mathrm{L}$ toxicity thresholds (U.S. Department of the Interior,1998). Average concentrations of boron, consistently exceeded the 13,000 $\mu \mathrm{g} / \mathrm{L}$ toxicity threshold for exposure to aquatic invertebrates (U.S. Department of the Interior, 1998) in Ponds 3 and 4, and approached or exceeded the 6,000 $\mu \mathrm{g} / \mathrm{L}$ level of concern (U.S. Department of the Interior, 1998) in Ponds 1 and 2. In contrast, average boron concentrations were consistently below the level of concern in the Freshwater Marsh and D-Pond/Hazard. Average concentrations of zinc exceeded the $30 \mu \mathrm{g} / \mathrm{L}$ level of concern (U.S. Department of the Interior,1998) in all SHP Ponds during at least one sampling event, exceeded the 110 $\mu \mathrm{g} / \mathrm{L}$ toxicity threshold in Pond 4 during fall 2007 and spring 2008, and were below the level of concern in all reference sites except Salton Sea during spring 2008. However, the toxicity of waterborne zinc is water quality dependent, and the hard water characteristics of the study area probably reduced its toxicity (U.S. Department of the Interior, 1998). Total mercury concentrations were $\leq 0.02 \mu \mathrm{g} / \mathrm{L}$ when measured fall 2006, therefore it was not analyzed at subsequent sampling intervals because this and other studies (for example, Riedel and others, 2002) indicated low potential risk at the Salton Sea. 
Sixty-two percent of the cumulative variation in elemental concentrations in surface water was explained by two principal components (fig. 10). Axis 1 (41\%, eigenvalue 7.0) was negatively correlated ( $r^{2} \geq 0.57$, eigenvalue 3.5 ) with boron, beryllium, cadmium, and cobalt, and positively correlated with barium $\left(r^{2}=0.30\right)$. Axis $2(21 \%)$ was positively correlated $\left(r^{2} \geq 0.59\right)$ with aluminum, iron, and vanadium. Water samples clearly separated in the ordination space by group as well as by site. Water samples from the SHP were associated with higher concentrations of elements loaded on Axis 1 (left hand side of fig. 10), beginning with Pond 4 and ending with Pond 1. In contrast, samples from all reference sites were associated with low concentrations along Axis 1 (right-hand side). The Alamo River and most Pond 4 samples were associated with high concentrations of elements loaded on Axis 2 (upper end), although most Pond 3 samples were associated with low concentrations along Axis 2 (lower end). All other samples did not strongly position along Axis 2. Total dissolved solids and soluble phosphorous were associated with Axis $1\left(r^{2} \geq 0.50\right)$, indicating that high concentrations of these nutrient measurements were correlated with high concentrations of elements loaded on Axis 1 . Nitrate was positively yet weakly associated $\left(r^{2}=0.21\right)$ with higher concentrations of elements loaded on Axis 2 .

\section{Organochlorines}

No organochlorine compounds were detected in water in fall 2006 when all SHP ponds were inundated (table 9). The DDT compound $p$,p' DDE was the only organochlorine detected in water samples (fall 2008); mean $p$,p' DDE concentrations in these samples were less than 2 times the detection limit and detected only in samples from Pond 1, Alamo River, and Freshwater Marsh. Concentrations of, $p, p^{\prime}$ DDE did not exceed $0.02 \mathrm{mg} / \mathrm{L}$ in any water sample.

\subsubsection{Sediment Contaminants}

Selenium

Selenium is an element of ecological concern and was detected in all sediment samples (table 10). Selenium concentrations were significantly higher $(F=53.7, P<0.0001)$ in sediments from the SHP group (lsmean $=1.81 \mu \mathrm{g} / \mathrm{g}$ ) compared to the reference group $(0.99 \mu \mathrm{g} / \mathrm{g})$, and marginally decreased from fall 2006 to the end of the study across both groups $(t=-1.8, P=0.07)$. Sediment selenium concentrations also differed among sites nested within groups $(F=24.7, P<0.0001)$; these were lowest in sediments from the Alamo River and D-Pond than all other sites (fig. 11). When only SHP ponds were examined from spring 2006 onward, the effect of time was not consistent across all ponds (Pond*time interaction: $F=6.1, P=0.001)$. Sediment selenium concentrations increased over time in Ponds $1-2(t \geq 2.7, P \leq 0.008)$ relative to a slight decrease at Pond $4(t=-1.8, P=0.08)$.

A selenium concentration $>4.0 \mu \mathrm{g} / \mathrm{g}$ is a suggested toxicity threshold in sediments, and concentrations from 1 to $4 \mu \mathrm{g} / \mathrm{g}$ are considered elevated above background concentrations (U.S. Department of the Interior, 1998, Hamilton, 2004). No sediment samples taken during the study exceeded the toxicity threshold. However, 83-100\% of the samples from SHP, Salton Sea, and Freshwater Marsh sites were above background concentrations whereas none from the Alamo River or D-Pond exceeded $1 \mu \mathrm{g} / \mathrm{g}$. 


\section{Elemental Concentrations and Compositional Patterns}

Elemental concentrations in sediment are provided in table 10. Average concentrations of arsenic did not exceed the toxicity threshold of $70 \mu \mathrm{g} / \mathrm{g}$ (dw) (Long and others, 1995; U.S. Department of the Interior,1998) at any site across all sampling periods, but approached or slightly exceeded the 8.2 $\mu \mathrm{g} / \mathrm{g}$ level of concern (Long and others, 1995; U.S. Department of the Interior, 1998) in Ponds 1and 2, and Freshwater Marsh during most sampling periods. Average concentrations of cadmium, chromium, copper, nickel, and silver never exceeded their respective levels of concern (effects range-low, Long and others, 1995) of 1.2, 81, 34, 20.9, and $1.0 \mu \mathrm{g} / \mathrm{g}$ at any site across all sampling periods. Average concentrations of lead slightly exceeded (by about $3.0 \mu \mathrm{g} / \mathrm{g}$ ) the $48.9 \mu \mathrm{g} / \mathrm{g}$ level of concern (Long and others, 1995) in Pond 2 during spring 2007 and fall 2008, and were below this level at all other sites across all sampling periods. Average concentrations of zinc approached or exceeded the $150 \mathrm{\mu g} / \mathrm{g}$ level of concern (Long and others, 1995) in Ponds 1 and 2 across all sampling periods, exceeded the 410 toxicity threshold (effects range-median, Long and others, 1995) by $9 \mu \mathrm{g} / \mathrm{g}$ in Pond 2 during fall 2008, and were below the level of concern in Ponds 3 and 4 and all reference sites across all sampling periods. Sediment total mercury concentrations were $\leq 0.06 \mu \mathrm{g} / \mathrm{g}$ in fall 2006, which is a value at least two times lower than the $0.15 \mu \mathrm{g} / \mathrm{g}$ level of concern (Long and others, 1995). Thus, mercury was not subsequently analyzed due to low potential risk.

Seventy-eight percent of the cumulative variation in elemental concentrations in sediments was explained by three principal components (fig. 12). Axis 1 (38\%, eigenvalue $=5.8)$ was negatively correlated with cobalt, chromium, copper, nickel, and vanadium $\left(r^{2} \geq 0.51\right)$, Axis 2 (23\%, eigenvalue = 3.4) was positively correlated with zinc, and lead $\left(r^{2} \geq 0.49\right)$, and Axis $3(17 \%$, eigenvalue $=2.5)$ was negatively correlated with boron, molybdenum, and selenium $\left(r^{2} \geq 0.57\right)$. Patterns of elemental differences among sites occurred in the ordination space. Although clear separation among sites was difficult to distinguish among sites along Axis 1, most samples from Ponds 1 and 2 were positively correlated with elements loaded on Axis 2. Notably, most samples from all SHP ponds followed a gradient of high boron, molybdenum, and selenium along Axis 3. Sediment salinity and composition measurements were mostly unrelated to Axes 1 and $2\left(r^{2} \leq 0.29\right)$. In contrast, organic matter and water conductivity exhibited a slight correlation with Axis $3\left(r^{2} \geq 0.34\right)$, which indicated a positive correlation with high concentrations of elements loaded on Axis 3.

\section{Organochlorines}

Organochlorines were not detected in sediments during any time except DDT compounds (table 11). Concentrations of $p, p^{\prime}$ DDE were detected in $98 \%$ of all samples but $p, p^{\prime} \mathrm{DDD}$, DDT, and $o, p^{\prime}$ DDE were detected only in samples from spring 2008 or fall 2008 at the reference sites or Pond 2, and were less than 3 times the detection limit.

Sediment $p, p$ ' DDE concentrations were significantly higher $(F=20.3, P=0.0001)$ at the reference group (lsmean $=0.02 \mu \mathrm{g} / \mathrm{g}$ ) than at the SHP group $(0.01 \mu \mathrm{g} / \mathrm{g}$ ), and did not change over time ( $t=-1.8, P=0.07)$. The $0.01 \mu \mathrm{g} / \mathrm{g}$ overall difference between groups was likely not biologically significant. Sites nested within groups differed $(F=25.4, P<0.0001)$, where $p$, $p$ ' DDE was highest in sediments from the Freshwater Marsh, and then the Alamo River, SHP Pond 3, and Salton Sea (fig. 13). 
Sediment $p, p$ ' DDE concentrations were lower in D-Pond (reference) than SHP Ponds 4, 2, and 1. When examining only SHP ponds, the effect of time was not consistent across all ponds (Pond*time interaction: $F=5.7, P=0.002)$. Sediment $p, p$ ' DDE concentrations decreased linearly over time in Pond $4(t=-4.0, P=0.002)$, but not in Ponds 1 , 2 , or $3(t \leq 1.5, P>0.15)$. No sediment sampled during the study exceeded the suggested toxicity threshold of $>2.5 \mu \mathrm{g} / \mathrm{g}$ for $p, p$ ’ DDE (U.S. Department of the Interior, 1998).

\subsubsection{Invertebrate Contaminants}

\section{Selenium}

Selenium was detected in all invertebrate samples (table 12). Selenium concentrations in Corixidae were significantly higher $(F=59.2, P<0.0001)$ at the SHP (lsmean $=4.4 \mu \mathrm{g} / \mathrm{g}$ ) than at the reference $(2.2 \mu \mathrm{g} / \mathrm{g})$ group, and did not change over time across both groups $(t=1.0, P=0.3)$. Selenium concentrations in Corixidae also differed among sites nested within groups $(F=5.3, P=0.0008)$, and were highest in SHP Ponds 1, 2, and 3, and lower in D-Pond, then Freshwater Marsh and Salton Sea (fig. 14). At the SHP, selenium concentrations in Corixidae did not differ among Ponds 1, 2, or $3(F=$ $0.05, P=0.9)$, but decreased linearly over time $(t=-3.2, P=0.003)$. Corixidae were abundant in Pond 4 only in fall 2006 when initially flooded, and Chironomidae were common only in SHP Pond 1 and the Salton Sea, Freshwater Marsh, and D Pond/Hazard reference sites.

Most suggested dietary (that is, invertebrate as avian prey) toxicity thresholds for selenium concentrations range between 3-4 $\mu \mathrm{g} / \mathrm{g}$ dry weight (Hamilton, 2004). Therefore, we examined the percentage of invertebrate samples exceeding $4.0 \mu \mathrm{g} / \mathrm{g}$ as a measure of selenium risk to higher trophic levels. The average percentage of Corixidae samples that exceeded the threshold was highest at SHP Ponds 1, 2, and 3 (67-80\%) and lowest at D-Pond, Salton Sea, and Freshwater Marsh (0-7\%); confidence intervals did not overlap between the high and low groups during the study (fig. 15). In contrast, the percentage of Chironomidae samples that exceeded the threshold was $100 \%$ at Salton Sea, 83\% at Freshwater Marsh, 33\% at Pond 1 and D-Pond, and 0\% at Pond 2. However, confidence intervals overlapped for all sites possibly because of small sample size ( $\leq 6$ composite samples per site) therefore Chironomidae risk estimates were not as robust as those for Corixidae. No Ephydridae sampled in Pond 4 exceeded the suggested dietary toxicity threshold for selenium.

\section{Selenium Bioconcentration and Interspecies Relations}

Selenium concentrations in Corixidae were positively related with those in sediment $(t=3.1, P=$ $0.03)$ and water $(t=14.0, P<0.0001)$, and Corixidae from the SHP had significantly higher average concentrations than those from the reference group when accounting for variation in selenium in sediment $(F=25.3, P=0.03)$ and water $(F=43.2, P=0.006$; fig. 16$)$. Corixidae selenium was more highly correlated with water selenium for both the SHP and reference groups than Corixidae selenium

and sediment selenium but the predictability was weak in all cases with the possible exception of Corixidae and water in the reference group (fig. 16). In contrast, there was no correlation of Chironomidae selenium concentrations with sediment $(t=1.3, P=0.2)$ or water selenium concentrations ( $t=1.9, P$ 0.09) but sample size was less than that for Corixidae. 
Corixidae selenium concentrations (geomean $=5.3 \mu \mathrm{g} / \mathrm{g}$ ) were higher than those in Chironomidae (3.6 $\mu \mathrm{g} / \mathrm{g}$ ) at SHP Ponds 1 and 2, whereas Chironomidae selenium concentrations (4.5 $\mu \mathrm{g} / \mathrm{g}$ ) were higher than those in Corixidae $(2.2 \mu \mathrm{g} / \mathrm{g}$ ) at the reference group (fig. 17). Selenium concentrations in Chironomidae and Corixidae were not related $(t=1.6, P=0.2)$ and did not differ between sites $(F=7.8, P=0.07)$. However, the relationship of selenium concentrations in Chironomidae and Corixidae was significant $(F=9.9, P=0.03)$ when a single site outlier was removed, which indicated that selenium in Corixidae and Chironomidae was highly correlated in the reference group but not the SHP group (fig. 18).

\section{Elemental Concentrations and Compositional Patterns}

Elemental concentrations in Corixidae and Ephydridae are provided in table 12. Concentrations of boron at SHP Ponds 3 and 4, barium at Freshwater Marsh, copper at SHP Ponds 1, 2, and 3, iron at all sites, manganese at all sites but more notably at the SHP, and zinc at all sites exceeded suggested background concentrations for estuarine invertebrates (Miles and Tome, 1997) during at least one sampling interval. Other than selenium (discussed above), dietary levels of boron ( $>30 \mu \mathrm{g} / \mathrm{g}$ ) was the only element in SHP Ponds 3 and 4 that may have a subtle but non-toxic effect on developing avian embryos (Smith and Anders, 1989). Mercury was not analyzed in invertebrates because of low or nondetectable concentrations in water and sediments.

Sixty-three percent of the cumulative variation in elemental concentrations in Corixidae was explained by two principal components (fig. 19). Axis 1 (39\%, eigenvalue $=6.6)$ was positively correlated with aluminum, cobalt, chromium, iron, and nickel $\left(r^{2} \geq 0.51\right)$, and Axis 2 (24\%, eigenvalue $=4.1$ ) was positively correlated with silver, copper, selenium, and zinc $\left(r^{2} \geq 0.53\right)$. Subtle separation occurred along Axis 1, where Corixidae from Salton Sea sites were associated with lower concentrations of elements loaded on Axis 1 compared to Corixidae from Pond 2. However, Corixidae clearly separated in the ordination space by group along Axis 2, where samples from the SHP group were associated with higher concentrations of elements loaded on Axis 2 (upper end) compared to the reference group (lower end).

\section{Organochlorines}

Similar to pattern observed for sediments, DDT compounds were the only organochlorines detected in invertebrates during the study (table 13). With the exception of one sample, $p$, $p$ ' DDE comprised all detected DDT compounds and was detected in $89 \%$ of all samples. Corixidae $p, p$ ' DDE concentrations did not differ significantly between groups (lsmeans: SHP $=0.11 \mu \mathrm{g} / \mathrm{g} \mathrm{dw}$, reference = $0.12 \mu \mathrm{g} / \mathrm{g} \mathrm{dw} ; F=0.1, P=0.9)$, and did not change over time across both groups $(F=3.2, P=0.8)$. Although concentrations were variable within sites, significant differences occurred among sites $(F=$ 6.9, $P<0.0001)$, with the highest least squares mean concentrations in Freshwater Marsh $(0.34 \mu \mathrm{g} / \mathrm{g}$ $\mathrm{dw})$ and Pond $2(0.16 \mu \mathrm{g} / \mathrm{g} \mathrm{dw})$, and lowest in D-Pond $(0.06 \mu \mathrm{g} / \mathrm{g} \mathrm{dw})$ and SHP Pond $3(0.04 \mu \mathrm{g} / \mathrm{g} \mathrm{dw})$ (fig. 20). When only SHP ponds were examined, $p, p$ ' DDE did not differ among ponds $(F=2.0, P=$ $0.14)$, and marginally increased over time $(t=1.9, P=0.07)$. No invertebrate sampled during the study exceeded the level of concern (> $10 \mu \mathrm{g} / \mathrm{g}$, dry weight) for insectivorous waterfowl (U.S. Department of the Interior, 1998). 


\subsubsection{Contaminants in Stilt Eggs}

\section{Selenium}

Selenium was detected in all fresh and salvaged (that is, abandoned or failed to hatch) stilt eggs (table 14). In 2006, selenium concentrations were significantly higher ( $F=9.9, P=0.006)$ in fresh eggs collected at the SHP (lsmean $=8.0 \mu \mathrm{g} / \mathrm{g} \mathrm{dw}$ ) than those from all reference sites $(4.9 \mu \mathrm{g} / \mathrm{g})$. Concentrations were lowest in eggs from D-Pond $(3.5 \mu \mathrm{g} / \mathrm{g})$ than eggs from Freshwater Marsh (6.9 $\mu \mathrm{g} / \mathrm{g})$, Pond 1 (7.4 $\mu \mathrm{g} / \mathrm{g})$, and Pond 2 (8.5 $\mu \mathrm{g} / \mathrm{g})(F=5.4, P=0.02)$ (fig. 21). In 2007, egg selenium concentrations did not differ between groups $(\mathrm{SHP}=5.6 \mu \mathrm{g} / \mathrm{g}$, reference $=5.3 \mu \mathrm{g} / \mathrm{g} ; F=0.01, P=0.9$ or among sites $(F=1.5, P=0.2)$. In 2008 , selenium concentrations were significantly higher $(F=9.4, P=$ $0.004)$ in eggs from the SHP (5.7 $\mu \mathrm{g} / \mathrm{g})$ than those from reference sites $(4.8 \mu \mathrm{g} / \mathrm{g})$. Among sites, concentrations were highest in eggs from Pond 3 and lowest in eggs from Hazard and FW Marsh $(F=$ 3.1, $P=0.03$ ). Notably, egg selenium concentrations were lower (and similar) at the SHP in 2007 and 2008 than 2006, and similar at the reference sites all years. Initial flooding of the SHP in 2006 probably influenced the spike observed, and selenium seemed to decline to equilibrium in eggs thereafter.

Egg selenium greater than $6.0 \mu \mathrm{g} / \mathrm{g}$ (dry weight) is a conservative measure of toxicity risk that is suggested to cause reproductive impairment (Hamilton, 2004; U.S. Department of the Interior, 1998) but a higher selenium toxicity threshold of $16 \mu \mathrm{g} / \mathrm{g}$ has been proposed by Fairbrother and others (2000). During this study, 47\% of the stilt eggs collected from the SHP and 39\% from the Freshwater Marsh/Morton Bay exceeded $6.0 \mu \mathrm{g} / \mathrm{g}$ (fig. 22). Overlapping confidence intervals indicated percentages did not differ significantly between SHP and Freshwater Marsh/Morton Bay eggs during any year. In 2006, 70\% of the eggs collected from the SHP and 83\% of those from the Freshwater Marsh /Morton Bay exceeded $6.0 \mu \mathrm{g} / \mathrm{g}$. The percentage of eggs $>6.0 \mu \mathrm{g} / \mathrm{g}$ decreased subsequently at the SHP but confidence intervals overlapped for all years, whereas it was significantly lower in 2008 than 2006 at Freshwater Marsh/Morton Bay. Spatially explicit egg selenium concentrations illustrated substantial variation among sites and years, with isolated hot spots $(>8.0 \mu \mathrm{g} / \mathrm{g})$ in SHP Ponds 1,2 , and 3 and the interior of the Freshwater Marsh (figs. 23A - 23C). During the study, no eggs collected from D-Pond or Hazard exceeded $6.0 \mu \mathrm{g} / \mathrm{g}$ nor did any egg collected exceed the proposed higher toxicity threshold of 16 $\mu \mathrm{g} / \mathrm{g}$ selenium.

For all fresh eggs collected at an incubation age of $\geq 18$ days, 8 of 24 (33\%) had malpositioned embryos; only 2 of these were malpositions typically considered fatal. The percentages of eggs with malpositioned embryos were identical at the SHP (33\%) and Freshwater Marsh (33\%) (fig. 24). Malpositioned embryos did not occur in eggs collected from D-Pond, Hazard, or Morton Bay. After controlling for group effects, egg selenium concentrations significantly influenced the likelihood of malpositions $\left(\chi^{2}=0.30, P=0.58\right.$, odds ratio $\left.=1.2,95 \% \mathrm{CI}=0.7-1.9\right)$ or fatal malpositions $\left(\chi^{2}=0.04\right.$, $P=0.83$, odds ratio $=1.0,95 \% \mathrm{CI}=0.5-2.4)$. Two eggs contained potentially deformed embryos, one exhibited underdeveloped skull and legs (5.3 $\mathrm{\mu g} / \mathrm{g}$ selenium), the other exhibited a curved billed and enlarged eyes $(11.5 \mu / g)$. 


\section{Elemental Concentrations and Compositional Patterns}

Elemental concentrations in stilt eggs are provided in table 14. Average concentrations of arsenic in eggs ranged from 0.70 to $1.5 \mu \mathrm{g} / \mathrm{g}$ among sites in 2006 and 2007 and arsenic was not detected in eggs from 2008 (table 14). Average arsenic concentrations in eggs from Pond 1 during 2006 slightly exceeded the $1.3 \mu \mathrm{g} / \mathrm{g}$ level of concern (U.S. Department of the Interior, 1998), but average concentrations were well below the 2.8 toxicity threshold (U.S. Department of the Interior, 1998) across all sites and years. Average boron concentrations were similarly low, ranging from 0.18 to $1.82 \mu \mathrm{g} / \mathrm{g}$ in eggs collected during the study, and were at least 7 times lower than $13.0 \mu \mathrm{g} / \mathrm{g}$ level of concern (U.S. Department of the Interior, 1998). Average concentrations of zinc ranged from 46.3 to $64.3 \mu \mathrm{g} / \mathrm{g}$, which generally exceeded the $50 \mu \mathrm{g} / \mathrm{g}$ level of concern but were well below the 2,100 $\mathrm{gg} / \mathrm{g}$ toxicity threshold (U.S. Department of the Interior, 1998). Most remaining elements were detected in less than $50 \%$ of all egg samples, which indicated relatively low exposure.

Unlike patterns observed for elements in water, sediments, and invertebrates, only $32 \%$ of the cumulative variation in elemental concentrations in fresh eggs was explained by two principal components. Axis $1(19 \%$, eigenvalue $=2.7)$ was positively correlated with boron, iron, and zinc $\left(r^{2}>\right.$ $0.38)$, and Axis $2(12 \%$, eigenvalue $=1.7)$ was negatively correlated with chromium and nickel. Eggs did not clearly separate in the ordination space by group or site (fig. 25A), but eggs collected in 2008 were associated with lower concentrations of elements loaded on Axis 1 (fig. 25B).

\section{Organochlorines}

The compound p,p' DDE comprised 93\% of the organochlorines detected and was found in all fresh stilt egg samples; concentrations in eggs by site averaged 1.0-6.4 $\mu \mathrm{g} / \mathrm{g}$ wet weight (table 15). Total PCBs comprised 5\% of organochlorines and was detected only in 2008 at average concentrations of $\leq 0.29 \mu \mathrm{g} / \mathrm{g}$. Only trace concentrations (generally less than 5 times the LOD) of the remaining suite of organochlorines comprised the remaining $2 \%$ of the total concentration.

On a fresh wet weight basis, concentrations of $p, p^{\prime}$ DDE in stilt eggs from 2006 did not differ among groups $(F=0.2, P=0.7)$. However, $p$, $p$ ' DDE in eggs from the SHP were significantly higher in 2007 (lsmean: SHP $=1.73 \mu \mathrm{g} / \mathrm{g}$, reference $=0.89 \mu \mathrm{g} / \mathrm{g} ; F=4.9, P=0.03$ ) and 2008 (SHP = $1.56 \mu \mathrm{g} / \mathrm{g}$, reference $1.08 \mu \mathrm{g} / \mathrm{g} ; F=3.9, P=0.05$ ) than in those from the reference sites (fig. 26). Concentrations of $p, p$ ' DDE did not differ among nested sites in any year $(F \leq 1.9, P \geq 0.13)$.

Eggshell thinning is a universally accepted indicator of $p, p$ ' DDE effects, and (wet weight) concentrations $>3.0 \mu \mathrm{g} / \mathrm{g}$ (Blus, 1996) to $>4.0 \mu \mathrm{g} / \mathrm{g}$ (Henny and Herron, 1989) have been suggested as detrimental to aquatic birds based on empirical studies. Henny and others (2008) did not find eggshell thinning in stilt eggs at $1.7 \mu \mathrm{g} / \mathrm{g} p, p^{\prime}$ DDE (fresh wet weight) at south Salton Sea wetlands; thus, we used this concentration along with the $4.0 \mu \mathrm{g} / \mathrm{g}$ wet weight threshold as conservative indicators of $p, p$ ' DDE risk. Of the stilt eggs collected during the study, 44\% (95\% CI: 33-56\%) at the SHP, 29\% (95\% CI: 13-45\%) at Freshwater Marsh/Morton Bay, and 21\% (95\% CI: 0-43\%) at D-Pond/Hazard exceeded $1.7 \mu \mathrm{g} / \mathrm{g} p, p^{\prime}$ DDE (fresh wet weight). On a wet weight basis, however, only 18\% (95\% CI: 9-27\%) of the SHP eggs, 3\% (95\% CI: 0-6\%) of the Freshwater Marsh/Morton Bay eggs, and 7\% (95\% CI: 0-7\%) of the D-Pond/Hazard eggs exceeded $4.0 \mu \mathrm{g} / \mathrm{g} p, p^{\prime}$ DDE. 


\subsubsection{Post-Hatch Spatial Use}

We radio-marked 132 stilt chicks within 1 day-post hatch; 18 were marked in 2006, 54 in 2007, and 60 in 2008. We obtained 253 locations in 2006, 471 in 2007, and 450 in 2008 (figs. 27A - 27C). Spatial utilization distribution estimates are provided in table 16. Home range estimates for populations of chicks hatched at the SHP ranged from 143 to 212 ha across all years. In contrast, estimates for populations of chicks hatched at Hazard were about one-half the size of the SHP home ranges, and the estimate for chicks hatched at the Freshwater Marsh was only 5 ha.

Home ranges or core areas of chicks hatched in specific areas did not overlap with other areas during the study (figs. 28A - 28C). In 2006 and 2007, home ranges for chicks hatched at the SHP encompassed the entire SHP, portions of the Freshwater Marsh to the north, Morton Bay to the south, and the Salton Sea mudflat to the west. In 2008, these home ranges encompassed a larger portion of Morton Bay as well as a privately owned waterfowl hunting club to the south, but did not extend as deeply into Freshwater Marsh as in 2006 and 2007. In addition, portions of the Salton Sea mudflat and Freshwater Marsh adjacent to the SHP became newly vegetated with Carex sp. and Rumex sp. during spring 2008. These may be reasons for less extensive chick movements into the Marsh interior during 2008. The SHP core area generally was associated with centers of activity that included the area of high nest density and the Freshwater Marsh. The Hazard home range encompassed the interior portions of the complex and extended farther eastward to the Alamo River in 2007. In contrast, the Hazard home range extended into the southern Hazard ponds and southeastern portion of Red Hill Bay in the Salton Sea in 2008. The Hazard core areas were comprised of multiple centers of activity that encompassed portions of the entire complex in both years. The small home range for chicks hatched at the Freshwater Marsh essentially comprised the nesting area along Alcott Road.

Chicks hatched at the SHP exhibited relatively little inter-pond movement, particularly during 2007 (table 17, fig. 29). For example, 84\% of all locations occurred in the same ponds where chicks were hatched, and only $30 \%$ of individual chicks actually moved to a non-hatch pond. The percentage of all locations occurring in the same ponds where chicks were hatched decreased to 59\% during 2008, which was mostly driven by the three chicks hatched in Pond 2 displaying all inter-pond movements into Pond 1. A similar pattern was observed during 2006 where all chicks from Pond 2 exhibited movement into Pond 1. Movements into the dry Ponds 3 and 4 occurred during emigration in 2006.

Maximum distances traveled from nest sites were greater for chicks hatched at the SHP than those at reference sites $(F=3.8, P=0.05)$, and for chicks hatched in 2007 than $2008(F=6.4, P=0.01)$ (table 18, figs. $30 \mathrm{~A}-30 \mathrm{C}$ ). Similarly, average distance traveled between successive locations were greater for chicks hatched at the SHP than those at reference sites $(F=6.1, P=0.05)$, and for chicks hatched in 2007 than $2008(F=7.1, P=0.009)$. Neither response variable was influenced by Julian hatch date $(F \leq-1.1, P \geq 0.29)$. Mean maximum distances from nest sites for chicks hatched at individual SHP ponds ranged from $205 \mathrm{~m}$ at Pond 2 in 2008 to 1,212 $\mathrm{m}$ at Pond 1 in 2006. In contrast, mean maximum distances from nest sites for chicks hatched at reference sites ranged from $52 \mathrm{~m}$ at Freshwater Marsh in 2008 to 584 m at Hazard in 2007 (table 18). 
Chicks tended to disperse from hatch sites within the SHP in a northwesterly direction towards the Freshwater Marsh during the study (table 18, figs. 30A-30C). Vectors for maximum distances from nest sites within the SHP were non-random for chicks hatched in 2006 and 2007

( $Z \geq 6.0, P<0.002)$, but not $2008(Z=1.9, P=0.15)$. The random movement in 2008 was likely due to chicks that emigrated southward from the SHP, which was not observed in 2006 or 2007 (fig. 30C). Chicks hatched at Hazard dispersed in a similarly non-random direction in 2007 and 2008 $(Z \geq 4.9 P<0.004)$, but in an east to southeasterly direction. In contrast, dispersal vectors for chicks hatched at the Freshwater Marsh in 2008 were random $(Z=2.4, P=0.08)$.

Three days was the median time to emigration across all sites and years for chicks that survived at least 3 days post-hatch (table 18). Chicks generally emigrated from the SHP within 2 days post-hatch with the exception of chicks in Pond 1 in 2007 (median = 6.0 days). Among years, 59\%, 85\%, and 68\% of chicks that survived at least 3 days post-hatch permanently left the SHP in 2006, 2007, and 2008, respectively. Moreover, $65 \%$ to $85 \%$ of the chicks presumably died that did not leave the SHP, depending on the scenario assumed for chicks that disappeared (see section, "Factors Influencing Survival ”). In contrast, chicks emigrated less frequently from reference sites, ranging from 5\% in 2008 to $60 \%$ in 2007 at Hazard. Notably, the median time to emigration for chicks hatched in Hazard during 2007 was 5.5 days.

\section{Factors Influencing Movements}

Water salinity greater than $32 \mathrm{~mL} / \mathrm{L}$ has been associated with physiological stress that may decrease chick survival (Hannam and others, 2003), and the SHP Ponds approached or exceeded this level during at least one year of the study (fig. 31A). Salinity in Pond 4 was exceptionally high, ranging from an average of 178 to 314 mL/L in 2007 and 2008, whereas Pond 1 was relatively fresh (ca. 15 $\mathrm{mL} / \mathrm{L}$ ) those years. Chick emigrated from the SHP towards areas with lower water salinity across all years (figs 32A-32C). Notably, the increased frequency of southward movements from the SHP in 2008 corresponded with a substantial decrease in salinity at Morton Bay compared to other years. Westward movements from the SHP were not observed in 2006 when salinity of the Salton Sea mudflat was higher compared to previous years. Only one chick that hatched at Hazard moved towards the high salinity waters of the Salton Sea.

The availability of cryptic cover or food also may have influenced movements. Structural cover measured in 2008 indicated ample vertical cover (and horizontal cover to a lesser extent) at the low salinity Freshwater Marsh and Hazard sites versus essentially non-existent cover at the SHP and Morton Bay (fig. 31B). Although not directly measured every year, the relative structural differences at these sites changed little during the study (authors, personal observation). Availability of Corixidae was similarly high (>1,000 individuals/sweep) at SHP Ponds 1 and 2 and Morton Bay in 2006 and 2007, and SHP Pond 3 and Freshwater Marsh in 2007 (fig. 31C). In contrast, food availability was relatively low in Freshwater Marsh and Salton Sea mudflat in 2006, and SHP Pond 4 and Hazard in 2007. Chicks exhibited little movement from the SHP to Morton Bay even though food availability was similar among sites, and instead moved towards sites with equal or lower food availability at Freshwater Marsh or the Salton Sea mudflats. In addition, low average movements corresponded to relatively low food availability for chicks at Hazard. Collectively, these patterns indicated that salinity and available cryptic cover might be more important factors influencing chick movements than food availability. 


\subsubsection{Post-Hatch Survival}

\subsubsection{Survival Rates}

Yearly estimates of survival to 21 days post-hatch are provided in table 19. In 2006 (pilot year), survival rates were 71\% and 49\% under censored scenarios 1 and 2, respectively. In 2007 and 2008, survival rates for chicks hatched at the SHP were $45 \%$ and $37 \%$ compared to $40 \%$ and $19 \%$ under scenarios 1 and 2, respectively. Survival within SHP ponds seemed to vary differently in 2007 and 2008. For example in 2007 under scenario 2, survival was 52\% for chicks hatched in Ponds 1 and 2 compared to $27 \%$ for chicks hatched in Ponds 3 and 4, whereas in 2008, survival for chicks hatched in Ponds 1 and 2 was $8 \%$ compared to 28\% for chicks hatched in Ponds 3 and 4 under the same scenario. In contrast, survival at reference hatch sites tended be high under scenario 2, ranging from a high of 83\% for chicks hatched in Hazard in 2007 to a low of 45\% for chicks hatched at the Freshwater Marsh in 2008.

Survivorship curves did not differ significantly by year $\left(\chi^{2}=1.3, P=0.26\right)$ under scenario 1 , but under scenario 2 decreased at a significantly steeper rate $\left(\chi^{2}=5.4, P=0.02\right)$ for chicks hatched in 2008 compared to 2007. Notably, survivorship curves decreased at a significantly steeper rate $\left(\chi^{2} \geq 6.1, P\right.$ $\leq 0.01$ ) for chicks hatched in the SHP compared to the reference group under both scenarios when chicks hatched in 2007 and 2008 were pooled (fig. 33). Survival to 21 days post-hatch for chicks hatched at the SHP was $41 \%$ and $30 \%$ compared to $69 \%$ and $56 \%$ for chicks hatched at the reference group under scenarios 1 and 2, respectively.

\section{Factors Influencing Survival}

Three sets of Cox-proportional hazard models were used to test covariate effects on estimated hazard ratios. For Set 1 covariates, the proportional hazards assumption was met as insignificant interactions for site * days post hatch $\left(\chi^{2} \leq 0.7, P \geq 0.79\right)$, and year * days post-hatch $\left(\chi^{2}<2.8, P>0.09\right)$ occurred under both censored scenarios. Therefore, non-time dependent site and year effects were included as covariates. The odds of mortality for chicks hatched at the SHP were $2.7\left(\chi^{2}=6.9, P=\right.$ $0.009)$ and $2.5\left(\chi^{2}=8.0, P=0.005\right)$ times higher than chicks hatched the reference group under scenarios 1 and 2, respectively. Year did not influence hazard ratios under scenario $1 \chi^{2}=2.7, P=0.10$ ), but the odds of mortality for chicks hatched during 2008 were $2.2\left(\chi^{2}=7.6, P=0.006\right)$ times higher than chicks hatched in 2007. After accounting for group and year effects, hazard ratios were not significantly influenced by Julian hatch date $\left(\chi^{2} \leq 0.08, P \geq 0.78\right)$ or body mass $\left(\chi^{2} \leq 0.9, P \geq 0.33\right)$ under either scenario.

For Set 2 covariates, selenium concentrations in sibling eggs did significantly increase the odds of mortality in radio-marked chicks under either scenario $\left(\chi^{2}=0.15, P>0.70\right)$. After accounting for any selenium effects and controlling for group and year, hazard ratios were not significantly influenced by Julian hatch date $\left(\chi^{2} \leq 0.2, P \geq 0.65\right)$ or body mass $\left(\chi^{2} \leq 0.8, P \geq 0.35\right)$ under either censored scenario. 
For Set 3 covariates, chicks that did not emigrate incurred significantly higher risks of mortality under both censored scenarios (fig. 34). Hazard ratios were $8.7\left(\chi^{2}=13.7, P=0.0002\right)$ and $7.3\left(\chi^{2}=\right.$ 14.6, $P=0.0001$ ) times higher under scenarios 1 and 2 , respectively, for chicks from both groups. After accounting for emigration effects, hazard ratios were not significantly influenced by Julian hatch date $\left(\chi^{2} \leq 3.2, P \geq 0.07\right)$ or body mass $\left(\chi^{2} \leq 0.2, P \geq 0.6\right)$ under either scenario. Similar patterns occurred when only chicks hatched at the SHP were considered, whereby the odds of mortality for chicks that failed to emigrate were $8.9\left(\chi^{2}=11.3, P=0.0008\right)$ and $10.9\left(\chi^{2}=14.4, P=0.0001\right)$ times higher under scenarios 1 and 2, respectively. Furthermore, the odds of mortality significantly decreased by 3.9\% (hazard ratio $=0.96, \chi^{2}=4.8, P=0.03$ ) with each daily increase in Julian hatch date under scenario 2. Julian hatch date did not significantly influence hazard ratios under scenario $1\left(\chi^{2}=2.2, P=0.14\right)$, nor did body mass influence hazard ratios under either scenario $\left(\chi^{2} \leq 0.005, P \geq 0.94\right)$.

\section{Causes of Mortality}

The most frequent cause of mortality across all groups and years was avian depredation, followed by unknown deaths, canals, and crack entrapment under censored scenario 1 (table 20, fig. 35). The relative importance of unknown predators and canals increased under censored scenario 2. Increased death rates by unknown predators under scenario 2 are plausible because the entire chick (including transmitter) can be consumed and signal no longer heard. In fact, the transmitter from one chick missing from the SHP was fortuitously found in a coyote scat $3 \mathrm{~km}$ to the southeast of the SHP 1 week later, with an audible radius of only about $50 \mathrm{~m}$. Furthermore, chicks that could not escape steep sided canals bordering the SHP to the north and south were likely depredated by aquatic predators (for example, largemouth bass, catfish, or large bullfrogs) because faint mortality signals emitting from underwater were heard moving upstream. Death from avian predators notably increased in 2008, which coincided with the new establishment of nesting gull-billed tern (Sterna nilotica) and California gull (Larus californicus) colonies at the SHP. Eleven deaths were associated with these predators, and five chicks hatched at the SHP were actually brought to the gull-billed tern colony (including one chick from Freshwater Marsh approximately $2 \mathrm{~km}$ to the north). Peregrine falcons were known but infrequent avian predators $(n=2)$. Death due to entrapment was most frequent during 2006; chicks emigrating from Ponds 1 and 2 fell into deep (about $0.5 \mathrm{~m}$ ) cracks in the dry beds of Ponds 3 and 4 prior to flooding in fall 2006. Crack-entrapment (off site) became less frequent in subsequent years.

\subsubsection{Ecological Risk Assessment}

The daily dosage of selenium was calculated for stilts using average sediment and Corixidae selenium concentrations at the SHP ponds and reference sites. The exposure values used to calculate the daily dosage from ingestion $\left(D i_{B N S T}\right)$ are provided in table 21 . The daily dosage ranged from 0.30 to 0.44 $\mu \mathrm{g} / \mathrm{g}$ at the SHP as a whole and $0.14-0.26 \mu \mathrm{g} / \mathrm{g}$ at the reference group. The low HQ (1.82) for the SHP ponds exceeded 1.0 but not the high HQ (0.45). For reference sites, the low (0.88) and high HQ (0.22) were less than 1.0. SHP pond specific daily doses (0.31-0.44) and hazard quotients (low HQ: 1.33-1.90, high HQ 0.33-0.47) were similar to those estimated for the entire SHP. Within the reference group, however, low HQs approached or exceeded 1.0 for Salton Sea and Freshwater Marsh sites, whereas high HQs were $<0.28$ at these sites. Conversely, the low HQ at D-Pond/Hazard (0.62) was <1.0. 
Our assessment assumed nominal movements between sites for breeding stilts. Movement of pre-breeding stilts typically decreases rapidly with the onset of nest-initiation (Demers and others, 2008), and egg selenium primarily represents dietary exposure within 2 weeks prior to follicle formation (Latshaw and Osman, 1975; DeVink and others, 2008). Given the spatial scale and juxtaposition of sites within our study area, a greater proportion of selenium exposure in nesting stilts was site specific. However, a lesser yet unknown proportion of selenium exposure may have been derived from areas in close proximity to nesting sites.

\section{Conclusions}

Our discrete measures of water quality, chemistry, and nutrients at SHP Ponds 1, 2, and 3 and reference sites were within acceptable limits for biological colonization, recruitment, and survival characteristic of salt pond systems with variable salinity (for example, Takekawa and others, 2006). Aquatic invertebrates rapidly colonized the SHP, where taxonomic richness and composition followed typical patterns governed largely by salinity gradients. Pond 4 was a notable exception where hypersaline conditions approached or exceeded levels harmful to most aquatic biota and waterborne inorganic contaminants concentrated. These conditions were expected in Pond 4, as this was a terminal pond designed to mimic conditions anticipated in brine sinks that will result as the Salton Sea recedes.

Selenium was the primary contaminant of concern, as concentrations frequently exceeded levels of concern or toxicity thresholds in all sample matrices at several reference and SHP sites, and bioconcentrated from water and to a lesser degree sediments to invertebrates. The low concentrations of selenium detected in all sample media from the D-Pond and Hazard reference sites indicated that the selenium risk was reduced at wetland habitats sustained by direct deliveries of Colorado River water; however, such 'clean' water is not considered a viable option for restoration. Alternatively, the blended water approach used for the SHP successfully diluted the high selenium concentrations detected in the Alamo River. Results from the predictive ecological risk assessment indicated slightly elevated risk of selenium toxicity for stilts nesting at the SHP but patterns of selenium in water, sediment, and invertebrates were relatively similar between the SHP and reference sites. Furthermore, we did not detect any relationship between selenium and embryonic malpositioning or post-hatch survival of stilt chicks, or a high frequency of embryonic deformities associated with selenium toxicity. Therefore, although a selenium risk was indicated at the SHP, it was not manifested by a reduction in the productivity parameters measured in the stilt avian endpoint. Our study demonstrated that the SHP model is a viable alternative for restoration of wetlands at the Salton Sea, but that resource managers will have to consider the potential risk of selenium. 
Widespread exposure to organochlorine pesticides was not evident. Only p,p’ DDE was consistently detected in upper trophic organisms (Corixidae and stilts). Concentrations of $p, p^{\prime}$ DDE in water were either below or $<2$ times the limit of detection, and concentrations in sediment were below levels of concern. These patterns for water and sediment indicated that exposure to $p, p$ ' DDE in Corixidae likely stemmed from its persistence from legacy use in the Imperial Valley and were below potentially harmful levels. Concentrations of $p, p$ ' DDE in stilt eggs may have reflected local as well as distant source exposure as well as longer term exposure due to its lipophillic nature. An unknown proportion of stilts nesting at the Salton Sea may over-winter in Baja California and the eastern coast of the Sea of Cortez (Robinson and others, 1999). Although some evidence suggests a lack of transboundary contaminant exposure between the southwestern United States and Latin America (Mora, 1997), elevated concentrations of $p, p$ ' DDE have been detected in sediments and biota of the Colorado River delta (García-Hernández and others, 2001), and recent exposure to organochlorine contaminants during migration to Mexico has been reported in osprey (Elliott and others, 2008).

Black-necked Stilts rapidly colonized the SHP during the first breeding season post-flood and maintained high numbers thereafter, although nest success was relatively low (about 53\%) during 2006 and 2007 (Anderson 2009). Survival of newly hatched chicks during the rearing life stage prior to fledging is an important measure of avian productivity. Post hatch chick survival was significantly higher at reference sites than at the SHP. Emigration from the SHP had a dramatic positive effect on post-hatch chick survival, whereby chicks that did not emigrate from the SHP were at least 9 times more likely to die than chicks that remained in the SHP. Chicks typically emigrated to adjacent habitats characterized by ample vegetative cover or water salinity less than 20 milliliters per liter. Although the SHP provided suitable habitat for nesting, adequate juxtaposition of low salinity habitats with an element of cryptic cover is a likely key element for maintaining productivity of stilts and similar waterbirds with precocial young. However, our results indicated that the SHP is a relatively dynamic ecosystem. For example, avian predators (that is, gull-billed terns and California gulls) did not occur frequently at the SHP during 2006 and 2007 but substantially contributed to chick mortality during 2008. Mammalian depredation of nests and chicks occurred despite the presence of an electric fence surrounding the SHP in 2007 (Anderson 2009). Movements of chicks hatched at the SHP were markedly lower during 2008 compared to previous years, which was may have been due to the freshening of Morton Bay and Salton Sea adjacent to the SHP, and increased vegetative cover at the southern end of the Freshwater Marsh. Lastly, a high frequency of chicks perished after becoming entrapped in the cracked dry ponds of SHP Ponds 3 and 4 during 2006. This cause of death was ameliorated after all pond cells were flooded in subsequent years, but future drying of the mudflats in the Salton Sea may present additional mortality hazards. 


\section{Project Evaluation and Effectiveness}

This study demonstrated that the design and logistics of the SHP was an ecologically viable solution to offset the anticipated problems of a receding Salton Sea. Although the duration of the study was brief, a fully functional ecological community established at the SHP. However, the long-term sustainability of that community is unknown. The experimental, shallow water saline habitat ponds were sufficient to support and sustain colonization and recruitment of invertebrates and birds as well as avian breeding and nesting at least in the short-term. Most biological and physical parameters measured were within acceptable ranges for sustaining viable avian centric communities based on our knowledge of the function of salt ponds. Although this study did not evaluate logistical or mechanical requirements necessary to sustain the ponds, observed problems of water delivery and flow into and between ponds undoubtedly contributed to within seasonal variation in physical and biological parameters measured at the ponds. However, these variations were not extraordinary or disruptive of aquatic biological cycles within the SHP during the course of the study.

\section{Suggestions for Future Study}

The duration of this study (chronologically 2.5 years but effectively only several months of total observations during this period) was insufficient to predict long-term benefits or problems that may be associated with ecosystem creation such as the SHP. For this reason, we recommend continued monitoring of ecological communities within the SHP, and also specific contaminants, that is, selenium and DDE and also possibly boron that may affect birds or their eggs and prey. Concurrently, we suggest expanding to a multi-guild approach to include higher trophic level avian consumers that include obligate piscivorous and omnivores. We suggest that it is necessary to identify spatially explicit sources of contaminant exposure in these endpoint consumers by study of stable isotopes $\left({ }^{34} \mathrm{~S},{ }^{15} \mathrm{~N},{ }^{13} \mathrm{C}\right)$ and telemetric monitoring of both local and long distance foraging and site use behavior of pre-breeding in birds. Importantly, the potential impacts of nest predation on avian productivity as a function of habitat composition and juxtaposition, nest density, and predator movement patterns needs to be determined. This includes the relationship between avian predators and structural within-pond cover on food web dynamics inclusive of fish, key invertebrates, and chicks at the SHP as well as the potential impacts of mammalian predators on all birds that utilize re-created sites, such as the SHP.

\section{Acknowledgments}

Financial support for this study was provided through the Proposition 50 Agricultural Water Quality Grant Program awarded by the California State Water Resources Control Board with matching funds from the Bureau of Reclamation (M. Walker). We thank the U.S. Geological Survey (USGS) Salton Sea Science Office for operational and scientific support and oversight (D. Barnum and L. Case). C. Schoneman, project leader of the U.S. Fish and Wildlife Service's Sonny Bono National Wildlife Refuge, provided invaluable logistical support. We thank USGS biologist T. Anderson and technicians/volunteers S. Beyer, E. Caceres-Ricca, H. Hanson, M. Harper, C. Massing, J. Mellinger, M. Miles, E. Morgan, K. Ramey, A. Story, W. Thornton, and S. Waters for their tireless work in the field and laboratory. B. Lasorsa (BMSL), C. Lusk (MSCL), D. Holstage (ANR), and T. Hammell (UCD Limnology Lab) provided expertise for analytical chemistry. C. Marn (U.S. Fish and Wildlife Service), J. Takekawa (USGS), J. Ackerman (USGS), and D. Tsao (USGS) provided valuable advice on chick tagging and radio-tracking. 


\section{References Cited}

Allison, P.D., 1995, Survival analysis using the SAS system: a practical guide: SAS Institute Inc., Cary, NC.

Anderson, T.A., 2009, Avian use and selenium risks evaluated at constructed saline habitat complex at the Salton Sea, California: M.S. Thesis, San Diego State University.

Blus L.J., 1996, DDT, DDD, and DDE in birds, in Beyer, W.N., Heinz, G.H., and Redmon-Norwood, A.W. (eds.), Environmental Contaminants in Wildlife: Interpreting Tissue Concentrations: SETAC Special Publication Series, CRC Press, Inc., Boca Raton, p. 49-71.

California Department of Water Resources, 2007, Final Programmatic Environmental Impact Report: Accessed October 15, 2009, at http://www.saltonsea.water.ca.gov/PEIR/

Demers, S.A., Colwell, M.A., Takekawa, J.Y., and Ackerman, J.T., 2008, Breeding stage influences space use of female American Avocets in San Francisco Bay, California: Waterbirds, v. 31, no. 3, p. 365-371.

DeVink, J.M.A., Clark, R.G., Slattery, S.M., and Scheuhammer, T.M., 2008, Effects of dietary selenium on reproduction and body mass of captive lesser scaup: Environmental Toxicology and Chemistry: v. 27, no. 2, p. 471-477.

Elliott, J.E., Morrissey, C.A., Henny, C.J., Inzunza, E.R., and Shaw, P., 2007, Satellite telemetry and prey sampling reveal contaminant sources to Pacific Northwest Ospreys: Ecological Applications, v. 17, no. 4, p. 1223-1233.

Evers, D.C., Taylor, K.M., Major, A., Taylor, R.J., Poppenga, R.H., and Scheuhammer, A.M., 2003, Common loon eggs as indicators of methylmercury availability in North America: Ecotoxicology, v. 12, no. 1-4, p. 69-81.

Fairbrother, A., Brix, K.V., DeForest, D.K., and Adams, W.J., 2000, Egg selenium thresholds for birds: A response to J. Skorupa's critique of Fairbrother et al., 1999: Human and Ecological Risk Assessment, v. 6, no. 1, p. 203-212.

García-Hernández, J., King, K.A., Velasco, A.L., Shumilin, E., Mora, M.A., and Glenn, E.P., 2001, Selenium, selected inorganic elements, and organochlorine pesticides in bottom material and biota from the Colorado River delta: Journal of Arid Environments, v. 49, no. 1, p.:65-89.

Griffith, B., and Youtie, B.A., 1988, Two devices for estimating foliage density and deer hiding cover: Wildlife Society Bulletin, v. 16, no. 2, p. 206-210.

Hamilton, R.B., 1975, Comparative behavior of the American Avocet and the Black-necked Stilt (Recurvirostridae): Ornithological Monograph, v. 17, p. 1-98.

Hamilton, S.J., 2004, Review of selenium toxicity in the aquatic food chain: Science of the Total Environment, v. 326, no. 1-3, p. 1-31.

Hannam, K.M., Oring, L.W., and Herzog, M.P., 2003, Impacts of salinity on growth and behavior of American avocet chicks: Waterbirds, v. 26, no. 1., p.119-125.

Heinz, G.H., Hoffman, D.J., and Gold, L.G., 1989, Impaired reproduction of mallards fed an organic form of selenium: Journal of Wildlife Management, v. 53, no. 2, p. 418-428.

Henny, C.J., Anderson, T.W., Crayon, J.J., 2008, Organochlorine pesticides, polychlorinated biphenyls, metals, and trace elements in waterbird eggs, Salton Sea, California, 2004: Hydrobiologia. v. 604, p. 137-149.

Henny, C.J., and Herron, G.B., 1989, DDE, selenium, mercury, and white-faced ibis reproduction at Carson Lake, Nevada: Journal of Wildlife Management, v. 53, no. 4, p. 1032-1045. 
Hooge, P.N., and Eichenlaub, B., 1997, Animal movement extension to Arcview: version 1.1. Alaska Biological Science Center, U.S. Geological Survey, Anchorage, Alaska.

Hoyt, D.F., 1979, Practical methods of estimating volume and fresh weight of bird eggs: The Auk, v. 96, no. 1, p. 73-77.

Hui, C.A., and Beyer, W.N., 1998, Sediment ingestion of two sympatric shorebird species: The Science of the Total Environment, v. 224, no. 1-3, p. 227-233.

Hutt, F.B., 1929, Studies in embryonic mortality in the fowl. I. The frequencies of various malpositions of the chick embryo and their significance: Proceedings of the Royal Society of Edinburgh, v. 49, p. 118-131.

Kruskal, J.B., 1964, Nonmetric multidimensional scaling: a numerical method: Psychometrika, v. 29, no. 2, p. 115-129.

Lawless, J.F., 2003, Statistical Models and Methods for Lifetime Data, $2^{\text {nd }}$ edition: Wiley and Sons, 580 p.

Latshaw, J.D., and Osman, M., 1975, Distribution of selenium in egg white and yolk after feeding natural and synthetic selenium compounds: Poultry Science, v. 54, p. 1244-1252.

Long, E.R., MacDonald, D.D., Smith, S.L., and Calder, F.D., 1995, Incidence of adverse biological effects within ranges of chemical concentrations in marine and estuarine sediments: Environmental Management, v. 19, no. 1, p. 81-97.

McCune, B., and Grace, J.B., 2002, Analysis of Ecological Communities: MJM Software, Gleneden Beach, OR, 300 p.

McCune, B., and Mefford, M.J., 2006, Multivariate analysis of ecological data: PC-ORD, Version 5.0. MJM Software, Gleneden Beach, OR.

Menke, A.S., 1979, Semiaquatic and aquatic Hemiptera of California: Bulletin of the California Insect Survey, v. 21, University of California Press, Berkeley, CA.

Miles, A.K., and Tome, M.W., 1997, Spatial and temporal heterogeneity in metallic elements in industrialized aquatic bird habitat: Environmental Pollution, v. 95, no. 1, p. 75-84.

Mineau, P., Collins B.T., Baril, A., 1996, On the use of scaling factors to improve interspecies extrapolation of acute toxicity in birds: Regulatory Toxicology and Pharmacology, v. 24, no. 1. p. 2429.

Mora, M.A., 1997, Transboundary pollution: Persistent organochlorine pesticides in migrant birds of the southwestern United States and Mexico: Environmental Toxicology and Chemistry, v. 16, no. 1, p. 311.

Ohlendorf H.M., 1998, Selenium, in Fairbrother, A., Locke, L.N., and Hoff, G.L. (eds.), Noninfectious Diseases of Wildlife: Iowa State University Press, Ames, IA. p. 128 - 140.

Ohlendorf, H.M., 2002, The birds of Kesterson Reservoir: a historical perspective: Aquatic Toxicology, v. 57 , p. $1-10$.

Ohlendorf, H.M., 2003, Ecotoxicology of selenium, in Cairns, J. (ed.), Handbook of Ecotoxicology, 2nd ed. Lewis Publishers, Boca Raton, FL, p. 465-500.

Pollack, K.H., Winterstein, S.R., Bunck, C.M., and Curtis, P.D., 1989, Survival analysis in telemetry studies: the staggered entry design: Journal of Wildlife Management, v. 53, p. 7-15.

Peng, Y., Hou, H., Wang, S., Cui, Y., and Zhiguo, Y., 2008, Nitrogen and phosphorus removal in pilotscale anaerobic-anoxic oxidation ditch system: Journal of Environmental Sciences-China, v. 20, no. 4, p. 398-403.

Riedel, R., Schlenk, D., Frank, D., and Costa-Pierce, B., 2002, Analyses of organic and inorganic contaminants in Salton Sea fish: Marine Pollution Bulletin, v. 44, no. 5, p. 403-411. 
Rigney, M., 2001. Black-necked Stilt (Himantopus mexicanus). California Wildlife Habitat Relationships System No. B538. Accessed October 15, 2009 at, http://www.dfg.ca.gov/biogeodata/cwhr/cawildlife.aspx/

Robinson, J.A., and Oring, L.W., 1996, Long-distance movements by American Avocets and BlackNecked Stilts: Journal of Field Ornithology, v. 67, no. 2, p. 307-320.

Robinson, J.A., Reed, J.M., Skorupa, J.P., and Oring, .LW., 1999, Black-necked Stilt (Himantopus mexicanus), The Birds of North America Online (A. Poole, Ed.). Ithaca: Cornell Lab of Ornithology; Retrieved from the Birds of North America Online: http://bna.birds.cornell.edu/bna/species/449/

Skorupa, J.P., 1998, Selenium poisoning of fish and wildlife in nature: lessons from twelve real-world examples, in Frankenberger, W.T., Jr., and Engberg, R.A. (eds.), Environmental Chemistry of Selenium: New York, Marcel Dekker, p. 315-354.

Shuford, W.D., Warnock, N., Molina, K.C., and Sturm, K., 2002, The Salton Sea as critical habitat to migratory and resident waterbirds: Hydrobiologia, v. 473, no. 1-3, p. 255-274.

Smith, G.J., and Anders, V.P., 1989, Toxic effects of boron on mallard reproduction: Environmental Toxicology and Chemistry: v. 8, no. 10, p. 943-950.

Takekawa, J.Y., Miles A.K., Schoellhamer D.H., Athearn N.D., Saiki M.K., Duffy W.D., Kleinschmidt S., Shellenbarger G.G., and Jannusch, C.A., 2006, Trophic structure and avian communities across a salinity gradient in evaporation ponds of the San Francisco Bay estuary: Hydrobiologia, v. 567, p. 307-327.

Thompson, B., and Lowe, S., 2004, Assessment of macrobethos response to sediment contamination in the San Francisco Estuary, California, USA: Environmental Toxicology and Chemistry v. 23, no. 9, p. 2178-2187.

U.S. Department of Interior, 1998, Guidelines for the interpretation of the biological effects of selected constituents in biota, water, and sediment: National Irrigation Water Quality Program Information Report No. 3, Denver, CO.

U.S. Environmental Protection Agency, Region 9, 2009, Biological Technical Assistance Group (BTAG) Recommended Toxicity Reference Values for Birds (Revision Date 02/24/09):Accessed October 16, 2009, at www.dtsc.ca.gov/AssessingRisk/upload/Eco_Btag-mammal-bird-TRV-table.pdf

U.S. Environmental Protection Agency, 1987, Ambient water quality criteria for selenium. Publication EPA 440/5-87-0006: U.S. Environmental Protection Agency, Washington, DC.

Westerskov, K., 1950, Methods for determining the age of game bird eggs: Journal of Wildlife Management, v.14, no. 1, p. 56-67.

Wilson, H.R., Neuman, S.L., Eldred, A.R., and Mather, F.B., 2003, Embryonic malpositions in broiler chickens and bobwhite quail: Journal of Applied Poultry Research, v. 12, no. 1, p. 14-23.

Zar, J.H., 1996, Biostatistical analysis, Third edition: Prentice Hall, Upper Saddle River, NJ, 662 p. 


\section{Figures}

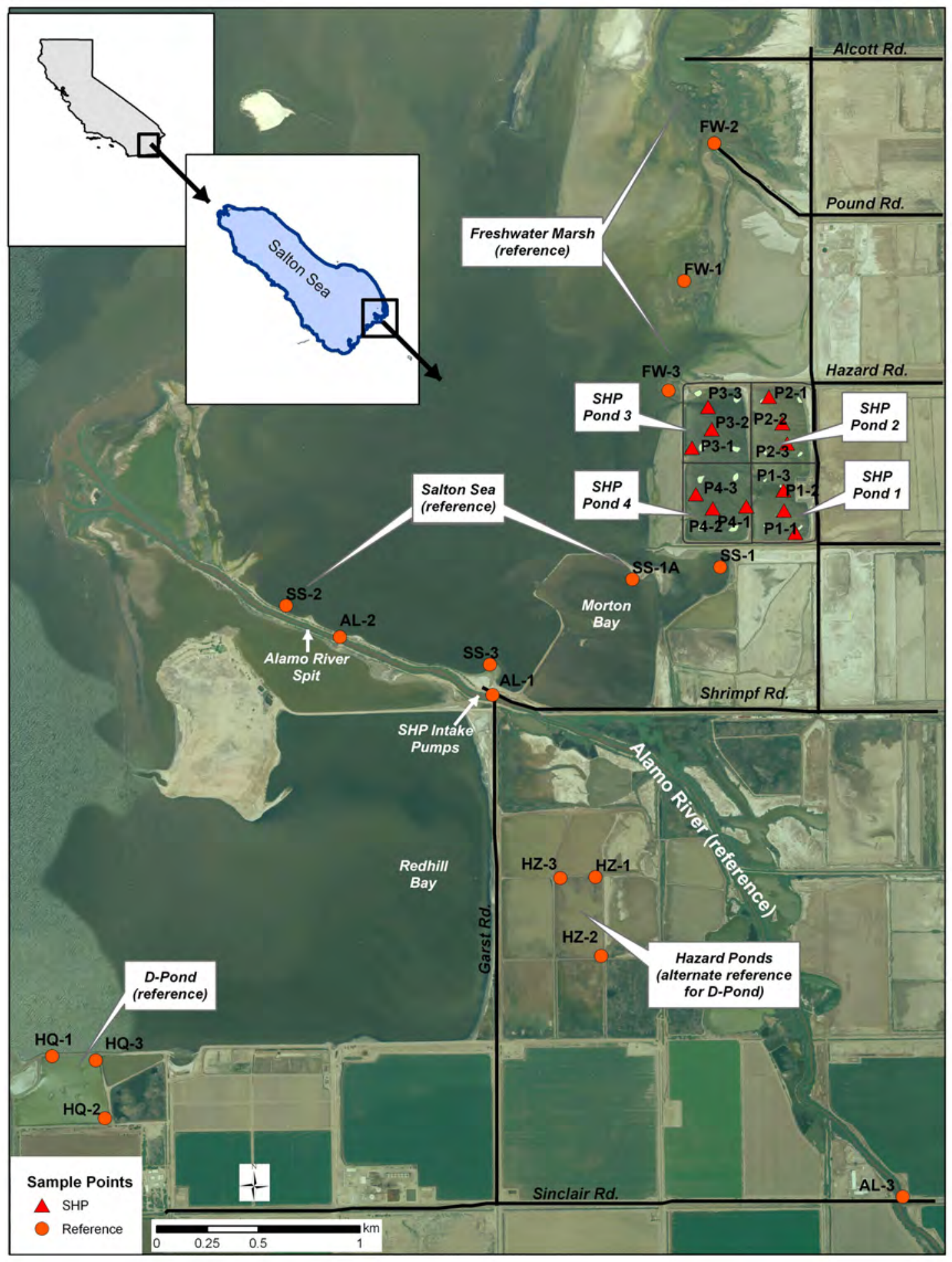

Figure 1. Sampling points, Ecosystem Monitoring Project, Salton Sea, California, 2006-08. SHP, saline habitat ponds. 


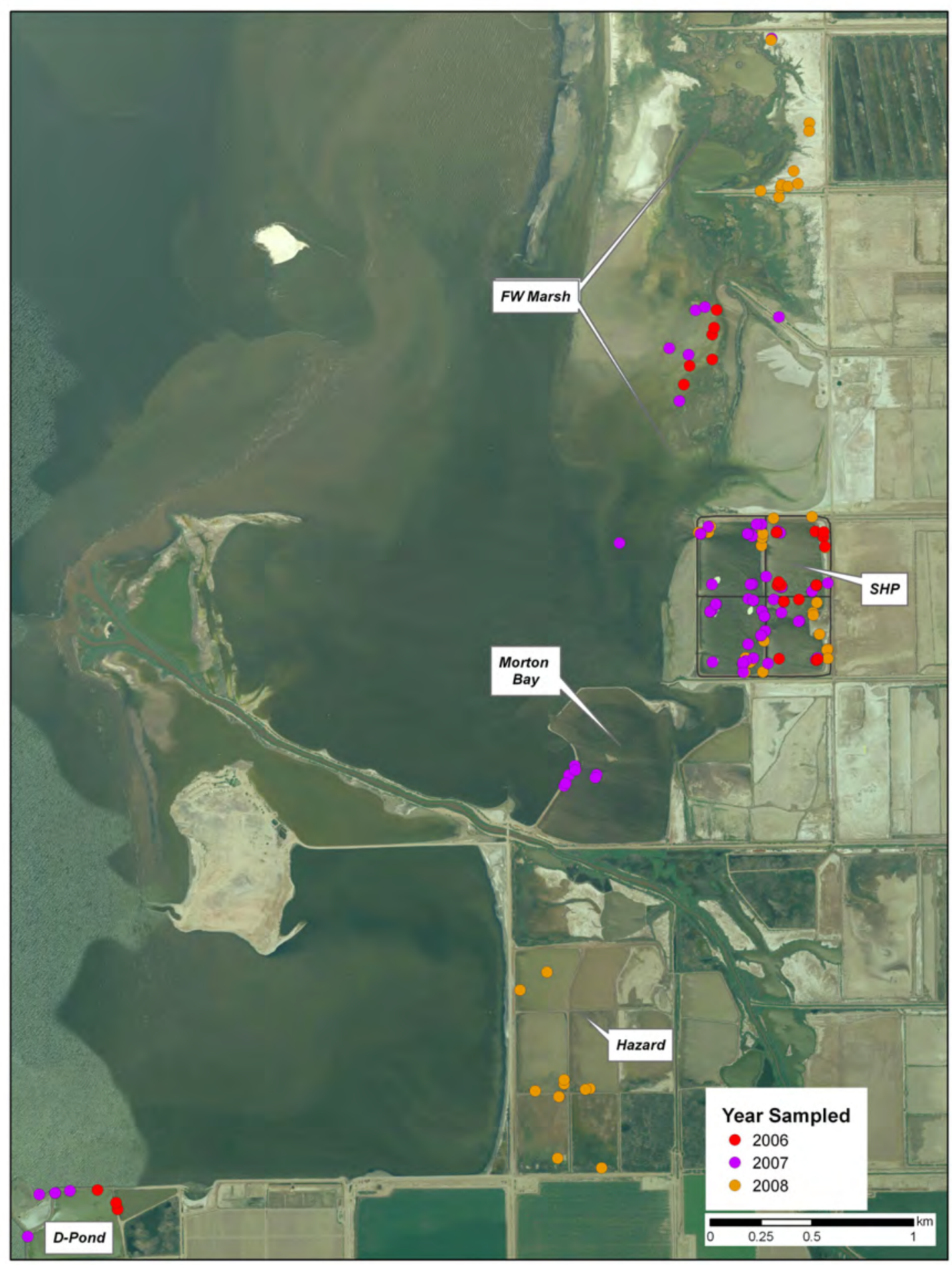

Figure 2. Black-necked Stilt egg collection locations, 2006, 2007, 2008, Ecosystem Monitoring Project, Salton Sea, California. SHP, saline habitat ponds; FW Marsh, Freshwater Marsh. 


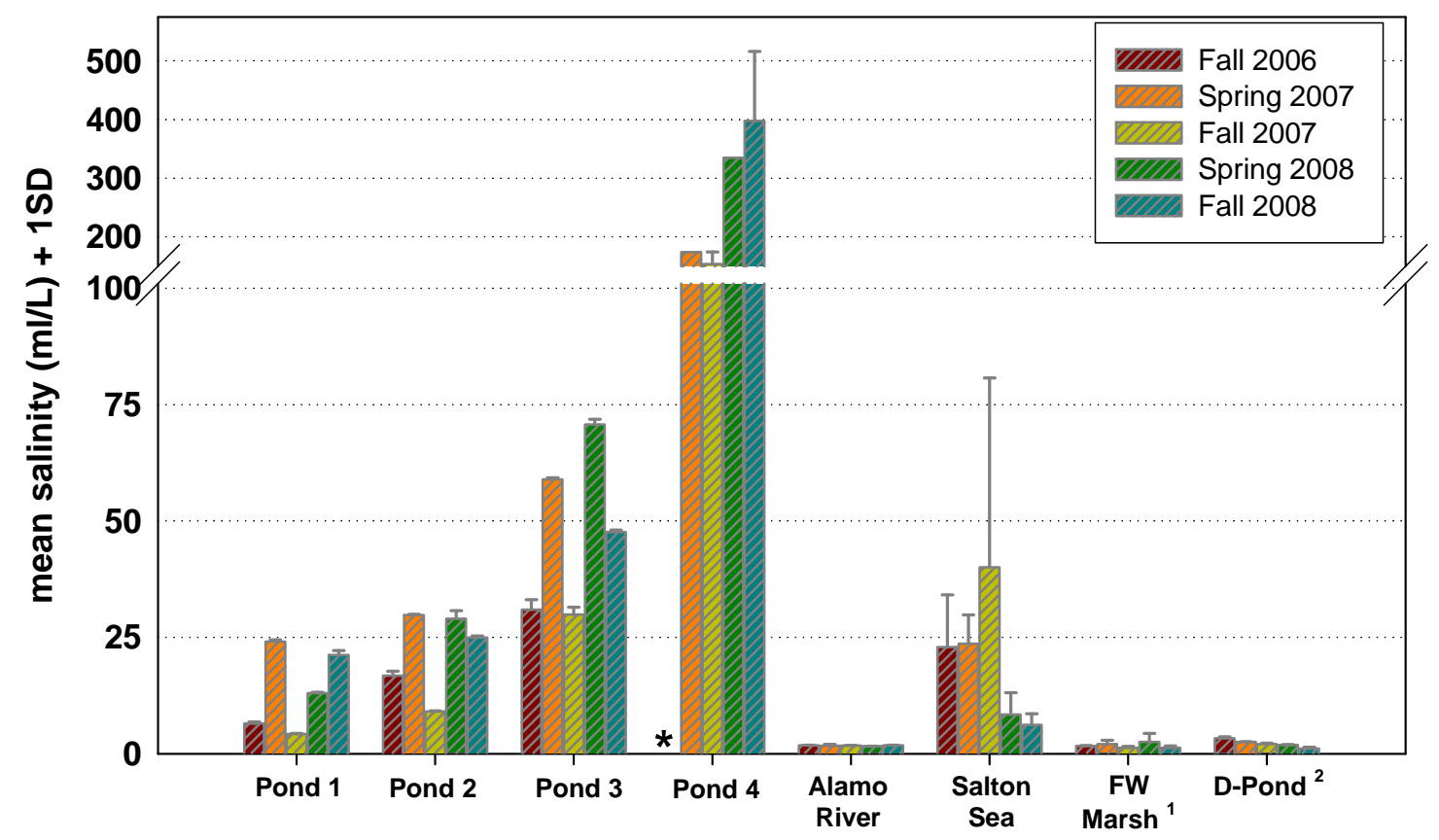

* Pond 4 salinity exceeded the instrument capability at that time.

${ }^{1} \mathrm{FW}$ Marsh = Freshwater Marsh.

${ }^{2}$ Hazard Pond sampled due to lack of water in D-pond during fall 2003

Figure 3. Average ( +1 standard deviation) for salinity concentrations in water samples collected from the saline habitat ponds (1-4) and reference sites ${ }^{1}$, Ecosystem Monitoring Project, Salton Sea, California, fall 2006-fall 2008. 


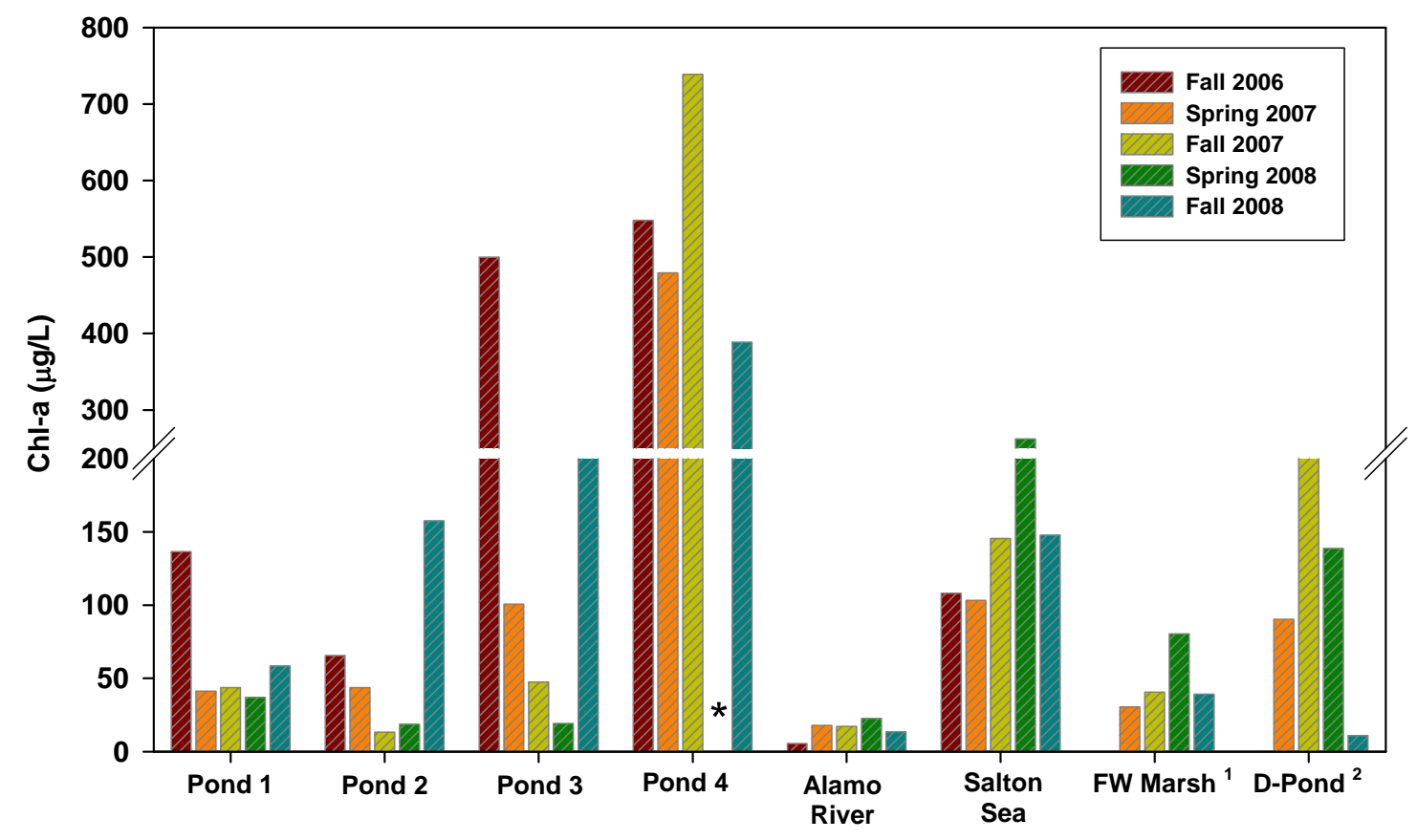

* Pond 4 salinity exceeded the instrument capability at that time.

${ }^{1}$ FW Marsh $=$ Freshwater Marsh.

${ }^{2}$ Hazard Pond sampled due to lack of water in D-pond during fall 2008.

Figure 4. Average chlorophyll-a concentrations in surface-water samples collected from the saline habitat ponds (1 - 4) and reference sites, Ecosystem Monitoring Project, Salton Sea, California, fall 2006-fall 2008. 

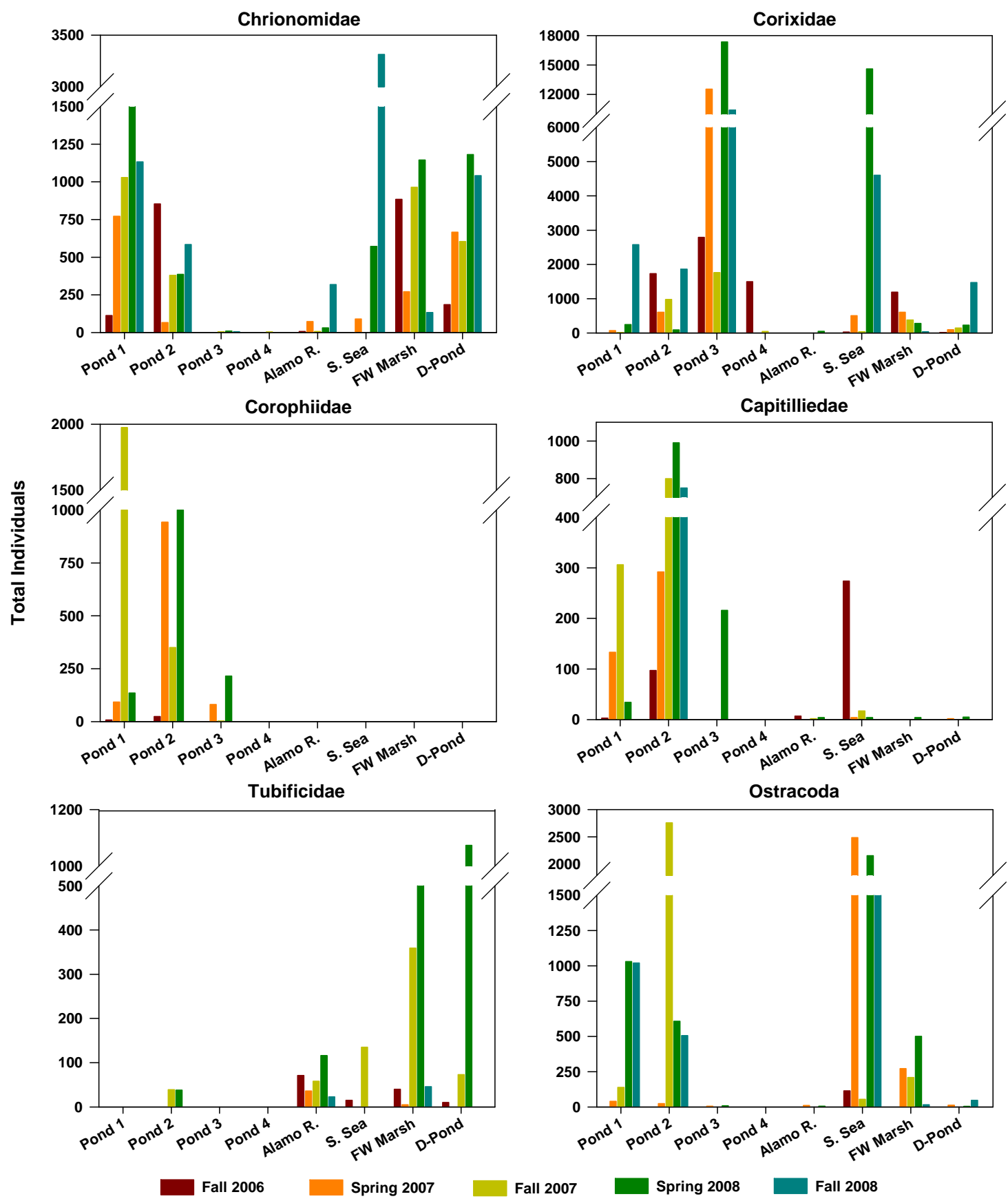

${ }^{1}$ FW Marsh = Freshwater Marsh; Hazard Pond sampled due to lack of water in D-pond during fall 2008.

Figure 5. Abundance of macro invertebrate taxa most frequently encountered at the saline habitat ponds (1-4) and reference sites ${ }^{1}$, Ecosystem Monitoring Project, Salton Sea, California, fall 2006fall 2008. 


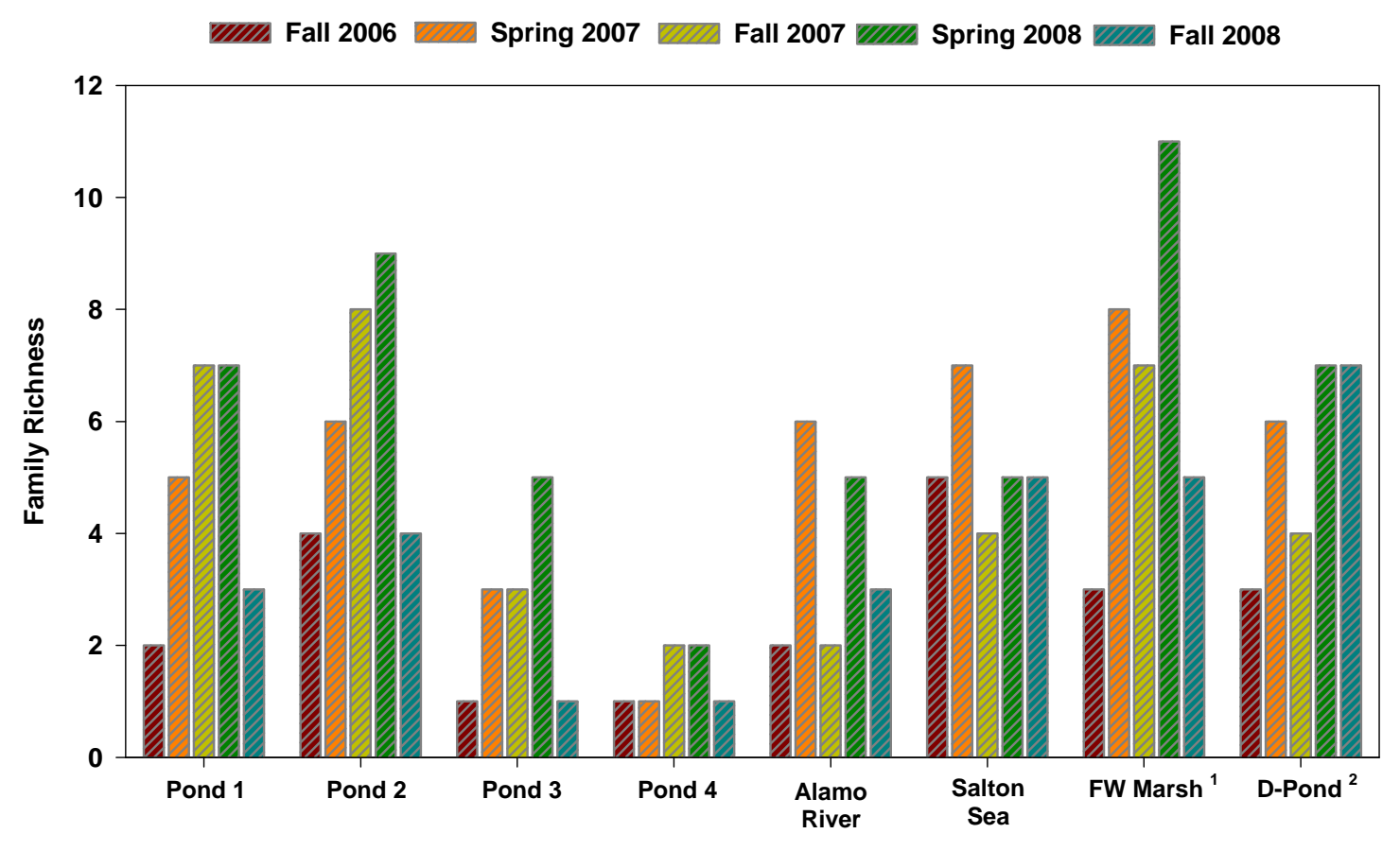

${ }^{1}$ FW Marsh $=$ Fresh Water Marsh.

${ }^{2}$ Hazard Pond sampled due to lack of water in D-pond during fall 2008

Figure 6. Taxonomic family richness for macro invertebrates sampled at the saline habitat ponds $(1-4)$ and reference sites, Ecosystem Monitoring Project, Salton Sea, California, fall 2006-fall 2008. Families include those with equal to or greater than 10 individuals enumerated at any site or time. 


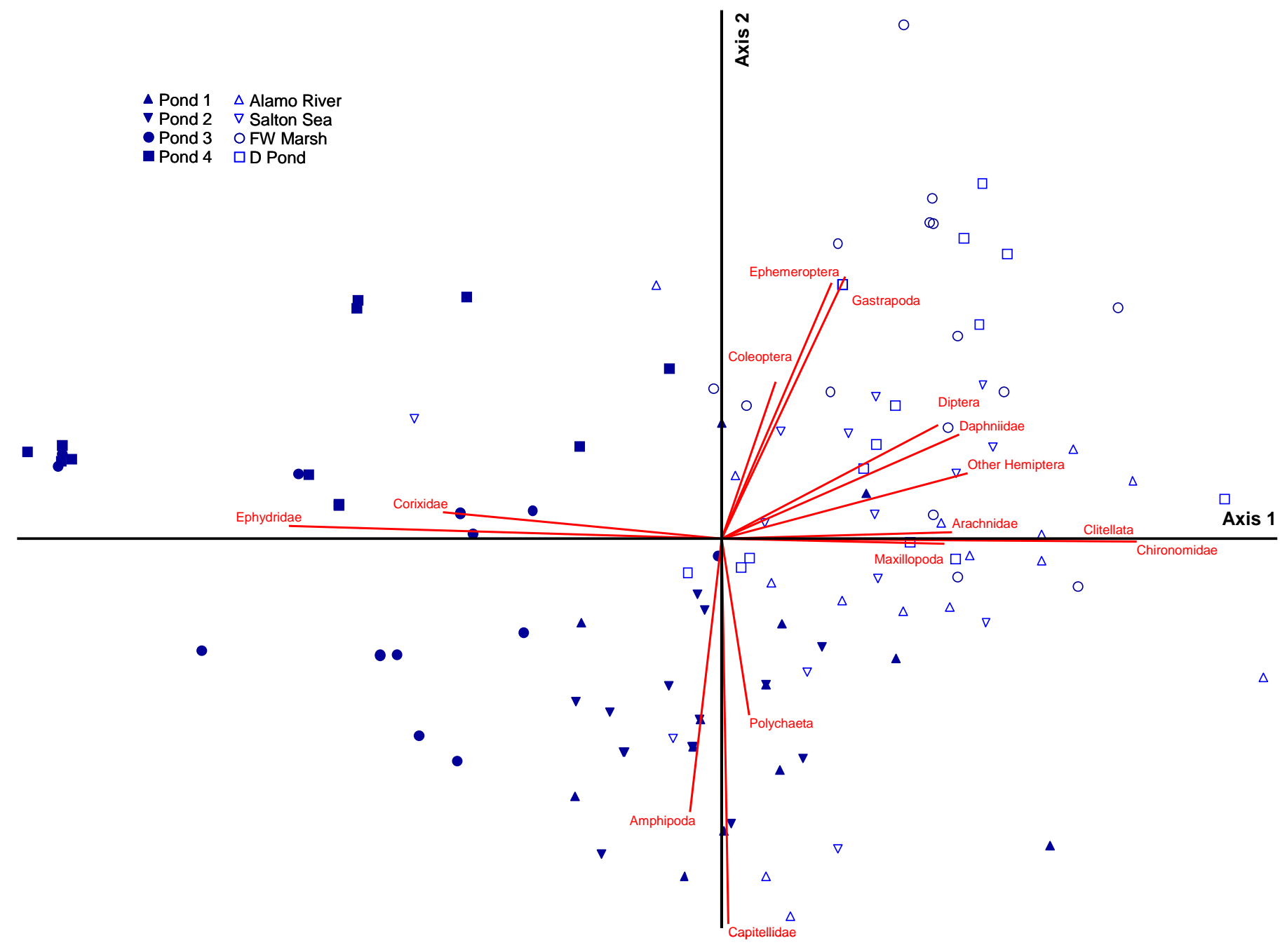

${ }^{1}$ FW Marsh = Freshwater Marsh, Hazard Pond sampled due to lack of water in D-pond during fall 2008.

Figure 7. Non-metric multidimensional scaling ordination of macro invertebrate community structure at the saline habitat ponds (1-4, closed symbols) and reference sites (open symbols) ${ }^{1}$, Ecosystem Monitoring Project, Salton Sea, California, fall 2006-fall 2008. Vectors (red lines) represent strength $\left(R^{2} \geq 0.30\right)$ and direction of species' loading in the ordination space. 


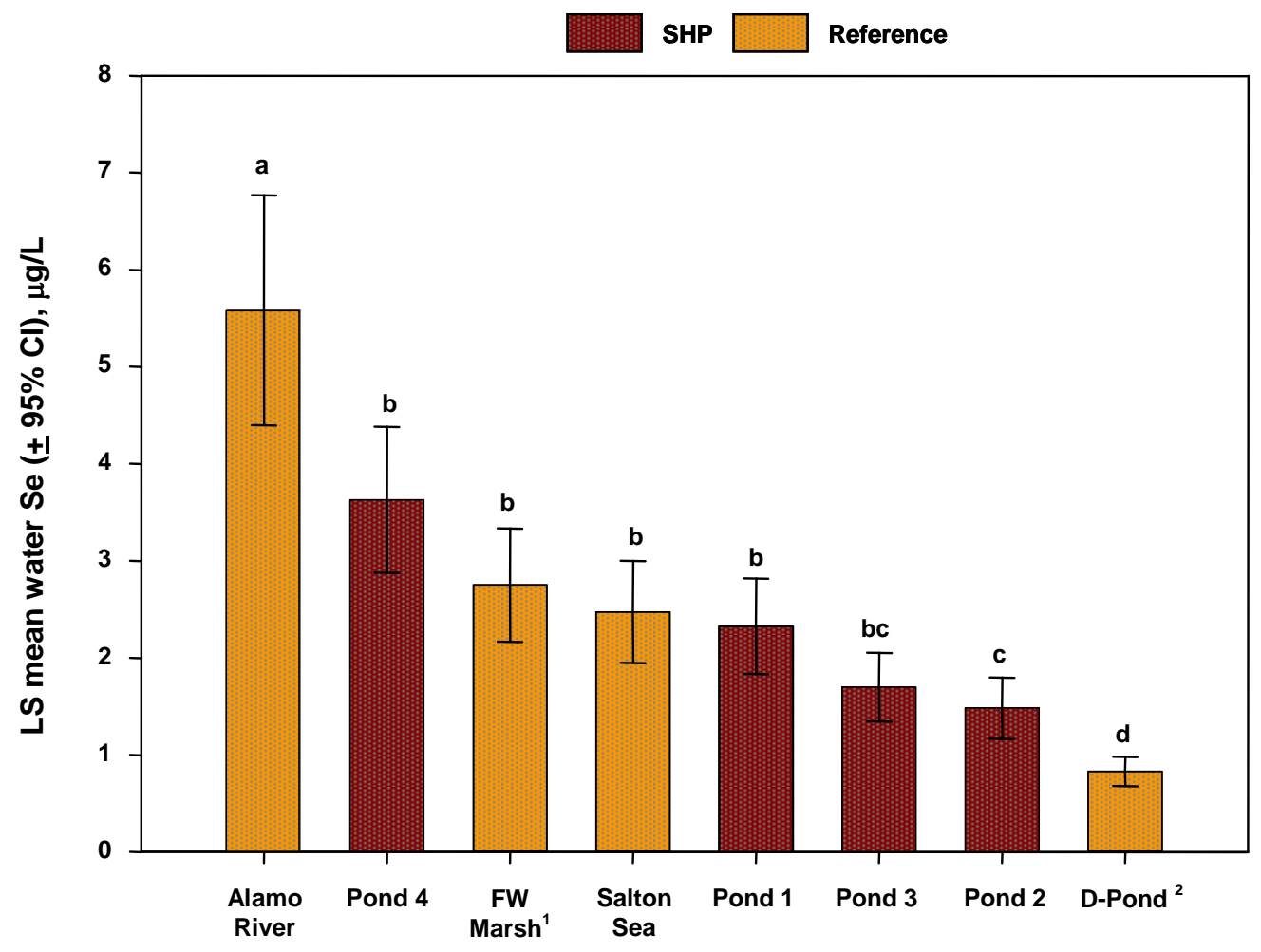

${ }^{1}$ FW Marsh $=$ Freshwater Marsh.

${ }^{2}$ Hazard Pond sampled due to lack of water in D-pond during fall 2008.

Figure 8. Least-squares means (and 95-percent confidence intervals) for selenium concentrations in surface-water samples collected from the saline habitat ponds (1-4, red bars) and reference sites (orange bars), Ecosystem Monitoring Project, Salton Sea, California, spring 2007-fall 2008. Means are ordered from high to low; means sharing the same letter do not differ significantly. 


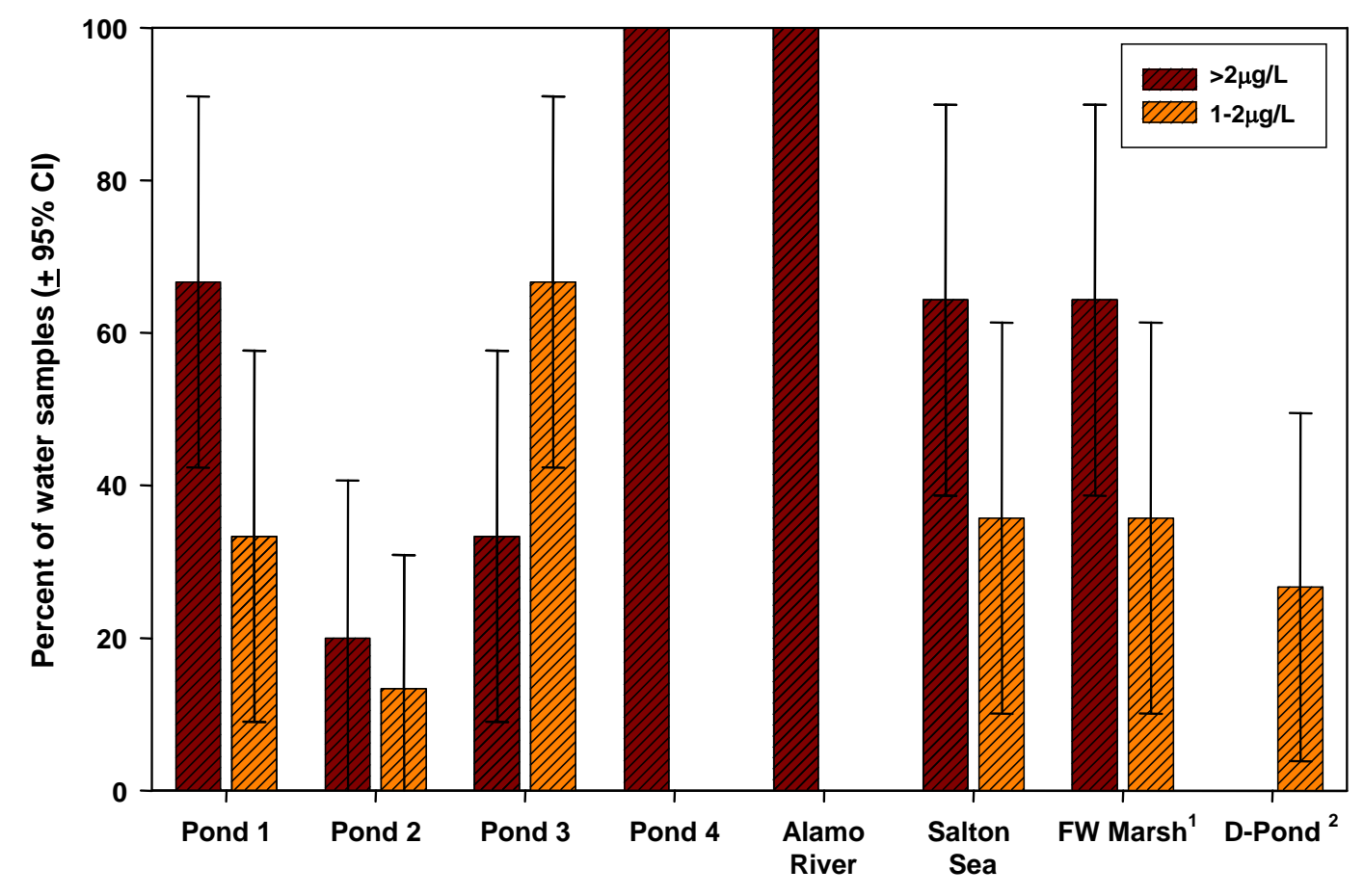

${ }^{1}$ FW Marsh $=$ Freshwater Marsh.

${ }^{2}$ Hazard Pond sampled due to lack of water in D-pond during fall 2008.

Figure 9. Average percentages (and 95-percent confidence intervals) for water samples collected from the saline habitat ponds (1-4) and reference sites exceeding selenium toxicity threshold (red bars) and background concentrations (orange bars), Ecosystem Monitoring Project, Salton Sea, California, spring 2007-fall 2008. 


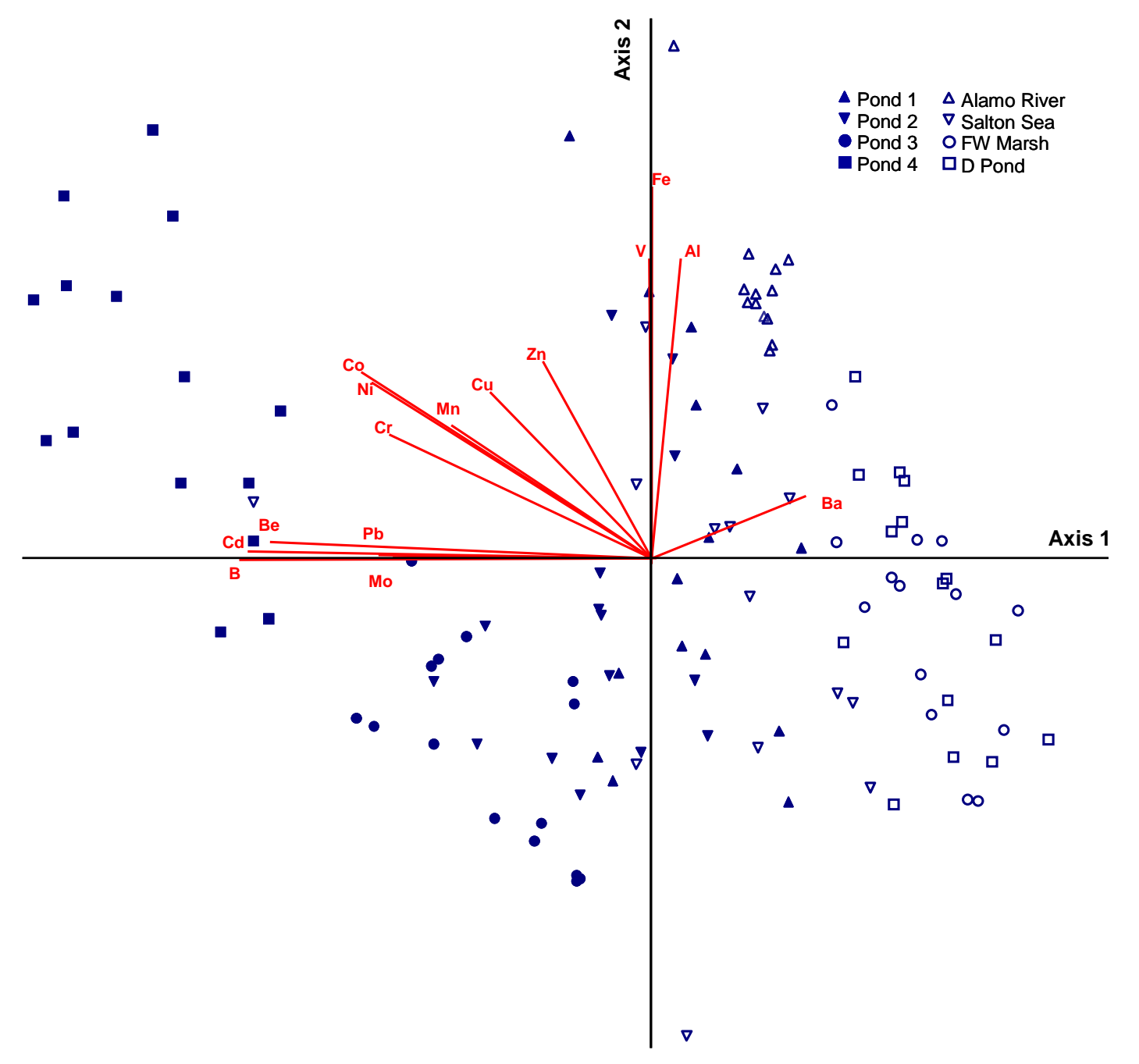

${ }^{1}$ FW Marsh = Freshwater Marsh, Hazard Pond sampled due to lack of water in D-pond during fall 2008.

Figure 10. Principal components analysis ordination of elemental concentrations in surface water at the saline habitat ponds (1-4, closed symbols) and reference sites ${ }^{1}$ (open symbols), Ecosystem Monitoring Project, Salton Sea, California, fall 2006-fall 2008. Vectors (red lines) represent strength $\left(R^{2} \geq 0.30\right)$ and direction of elemental loadings in the ordination space. 


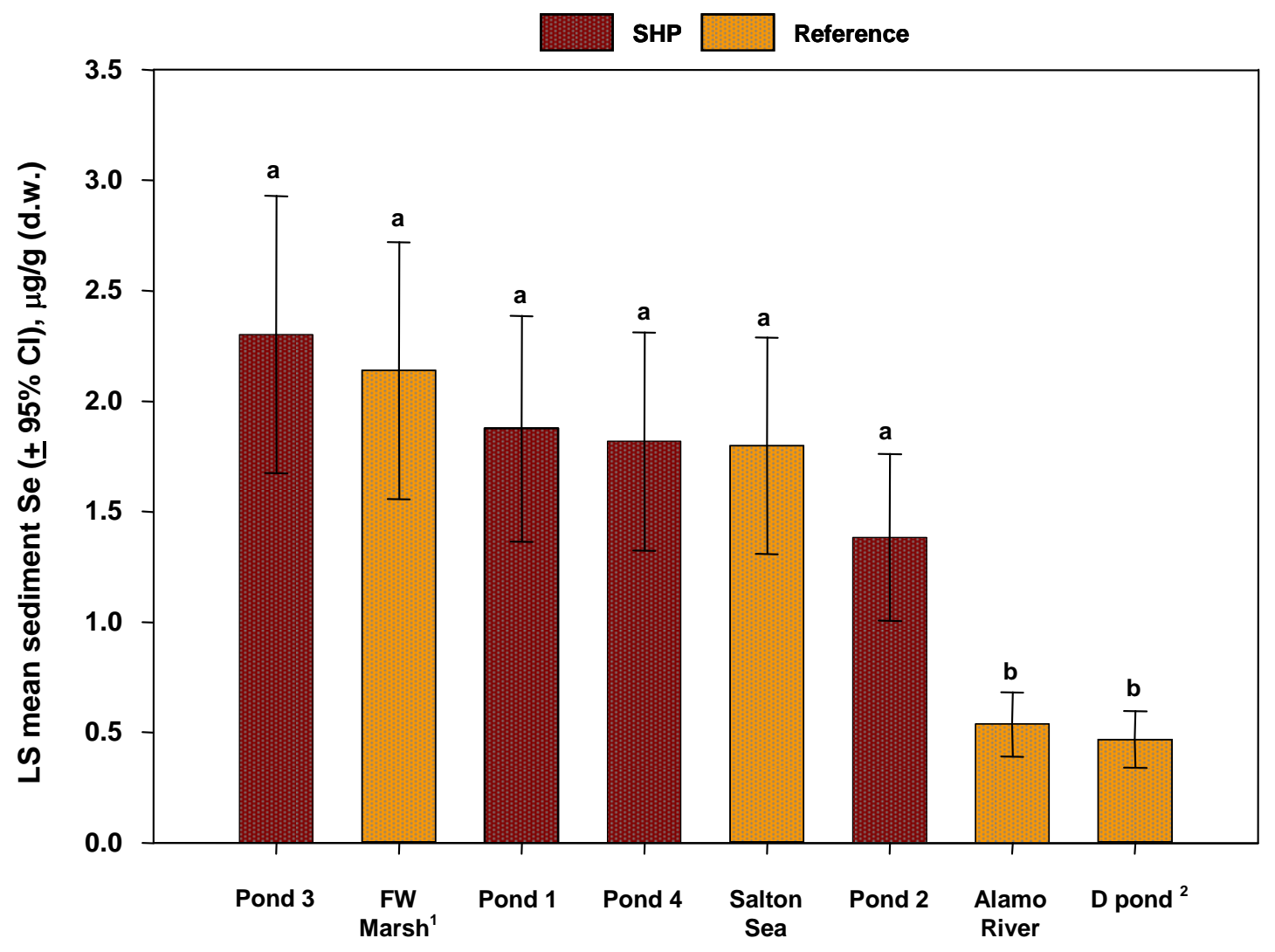

${ }^{1}$ FW Marsh $=$ Freshwater Marsh.

${ }^{2}$ Hazard Pond sampled due to lack of water in D-pond during fall 2008.

Figure 11. Least-squares means (and 95-percent confidence intervals) for selenium concentrations in sediment samples collected from the saline habitat ponds and reference sites, Ecosystem Monitoring Project, Salton Sea, California, fall 2006-fall 2008. Means are ordered from high to low; means sharing the same letter do not differ significantly. 


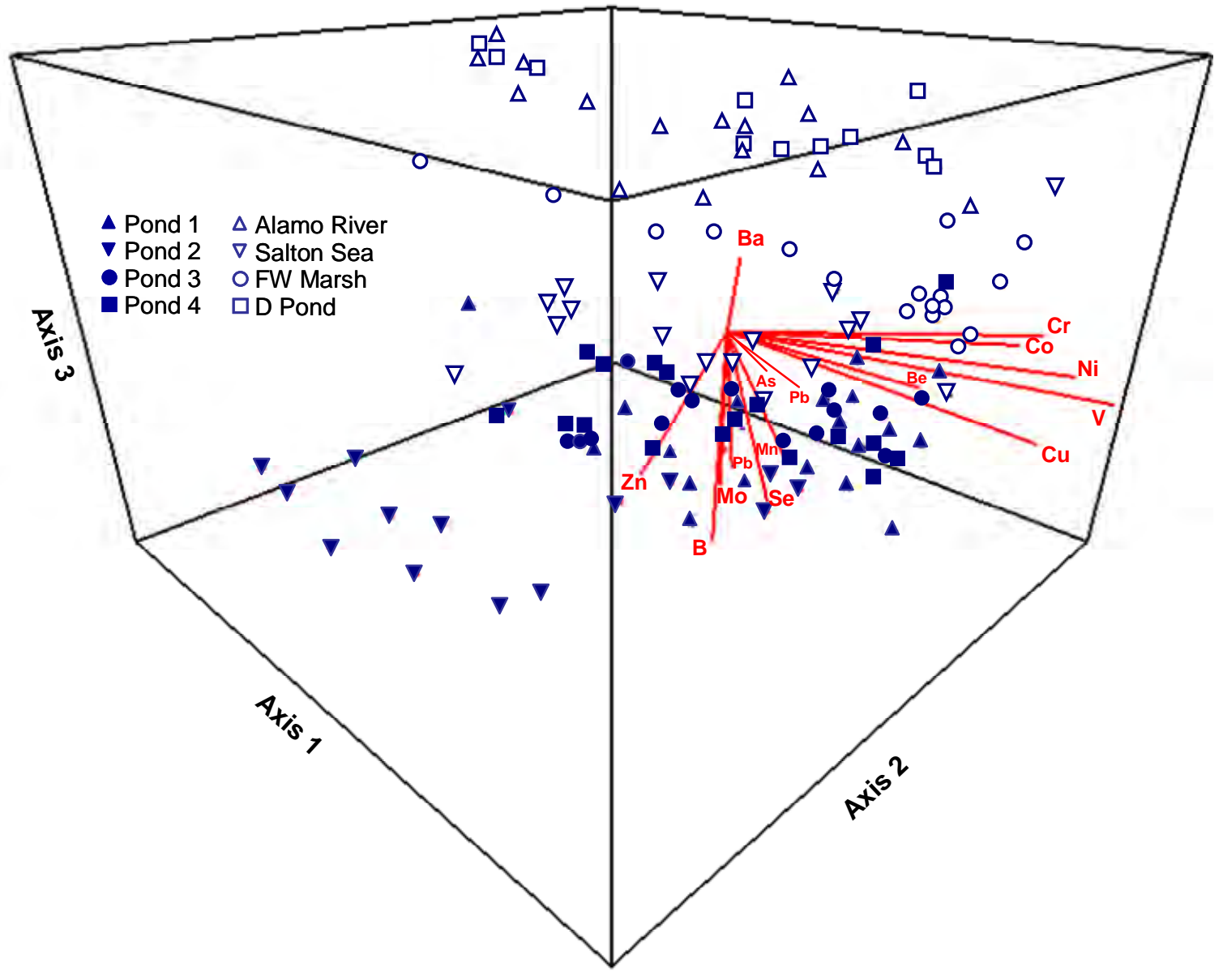

${ }^{1}$ FW Marsh = Freshwater Marsh, Hazard Pond sampled due to lack of water in D-pond during fall 2008.

Figure 12. Three dimensional principal components analyses ordination of elemental concentrations in sediments at the saline habitat ponds (1-4) and reference sites ${ }^{1}$, Ecosystem Monitoring Project, Salton Sea, California, fall 2006-fall 2008. Vectors (red lines) represent strength $\left(R^{2} \geq 0.30\right)$ and direction of elemental loadings in the ordination space. 


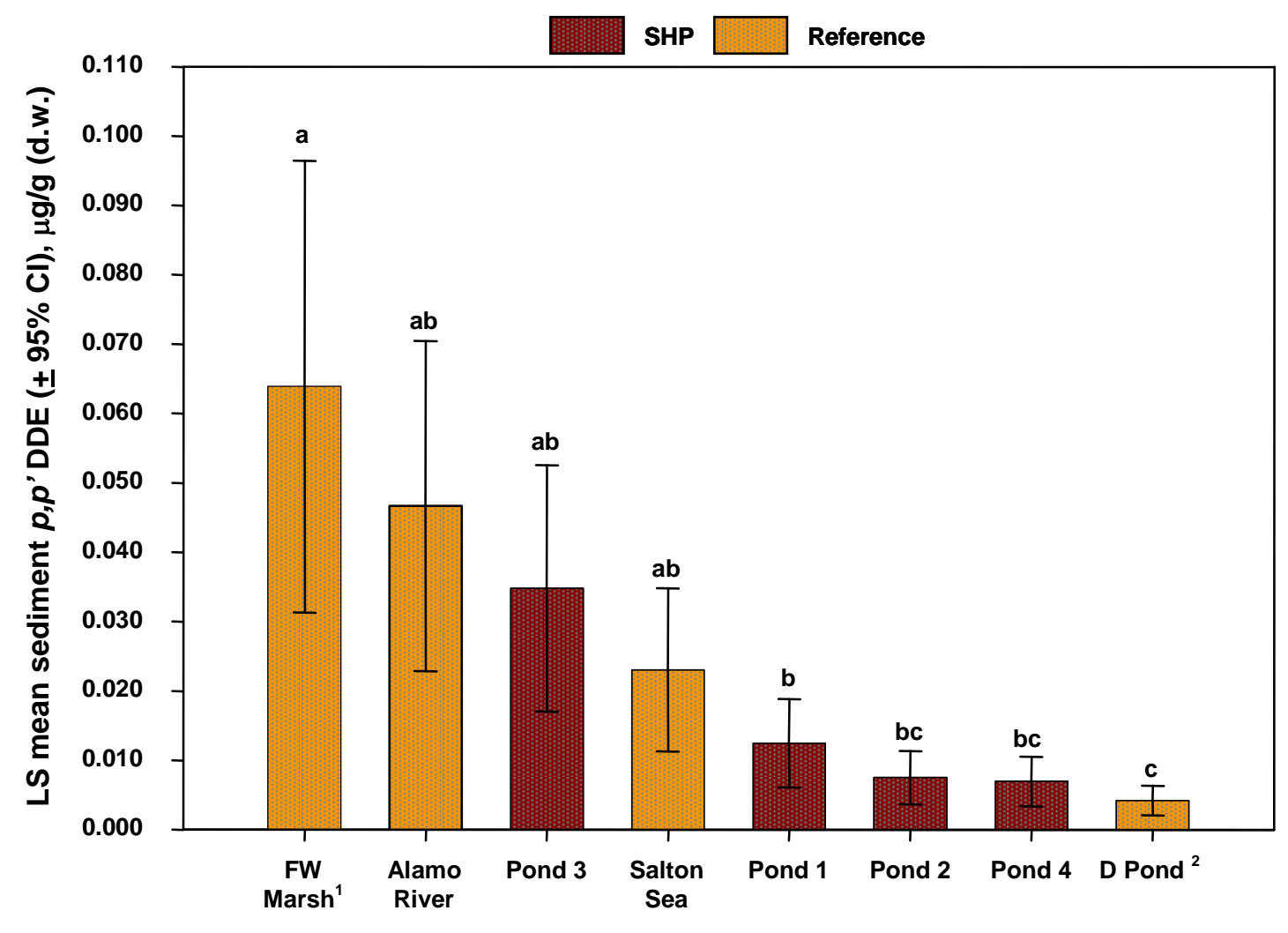

${ }^{1} \mathrm{FW}$ Marsh = Freshwater Marsh.

${ }^{2}$ Hazard Pond sampled due to lack of water in D-pond during fall 2008

Figure 13. Least-squares means (and 95-percent confidence intervals) for $p, p^{\prime}$ DDE concentrations in sediment samples collected from the saline habitat ponds (1-4, red bars) and reference sites (orange bars), Ecosystem Monitoring Project, Salton Sea, California, fall 2006-fall 2008. Means are ordered from high to low; means sharing the same letter do not differ significantly. 


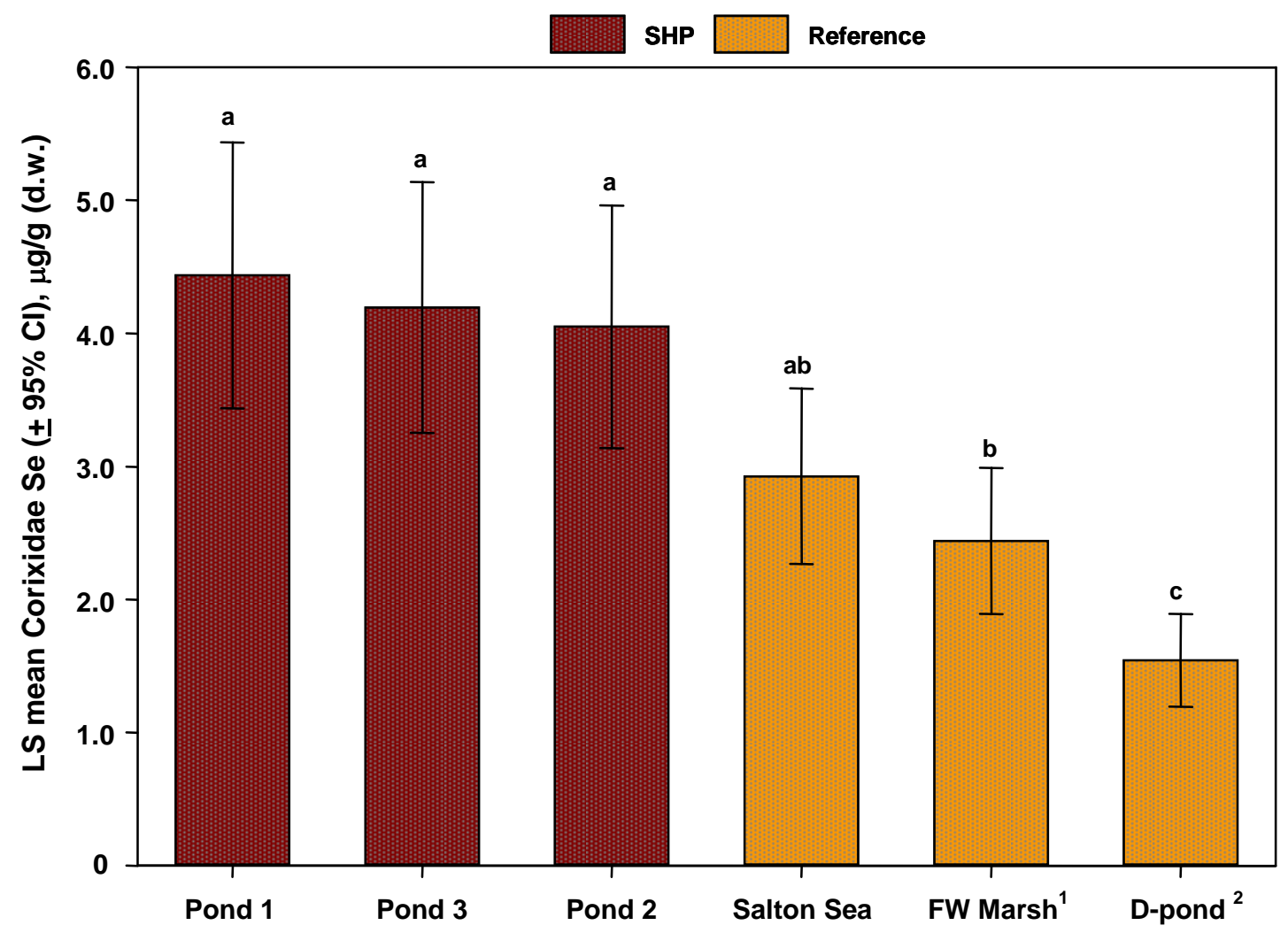

${ }^{1}$ FW Marsh $=$ Freshwater Marsh.

${ }^{2}$ Hazard Pond sampled due to lack of water in D-pond during fall 2008.

Figure 14. Least-squares means (and 95-percent confidence intervals) for selenium concentrations in Corixidae samples collected from the saline habitat ponds (1-4, red bars) and reference sites (orange bars), Ecosystem Monitoring Project, Salton Sea, California, fall 2006-all 2008. Means are ordered from high to low; means sharing the same letter do not significantly differ. Pond 4 was omitted because it only contained Corixidae samples in fall 2006. 


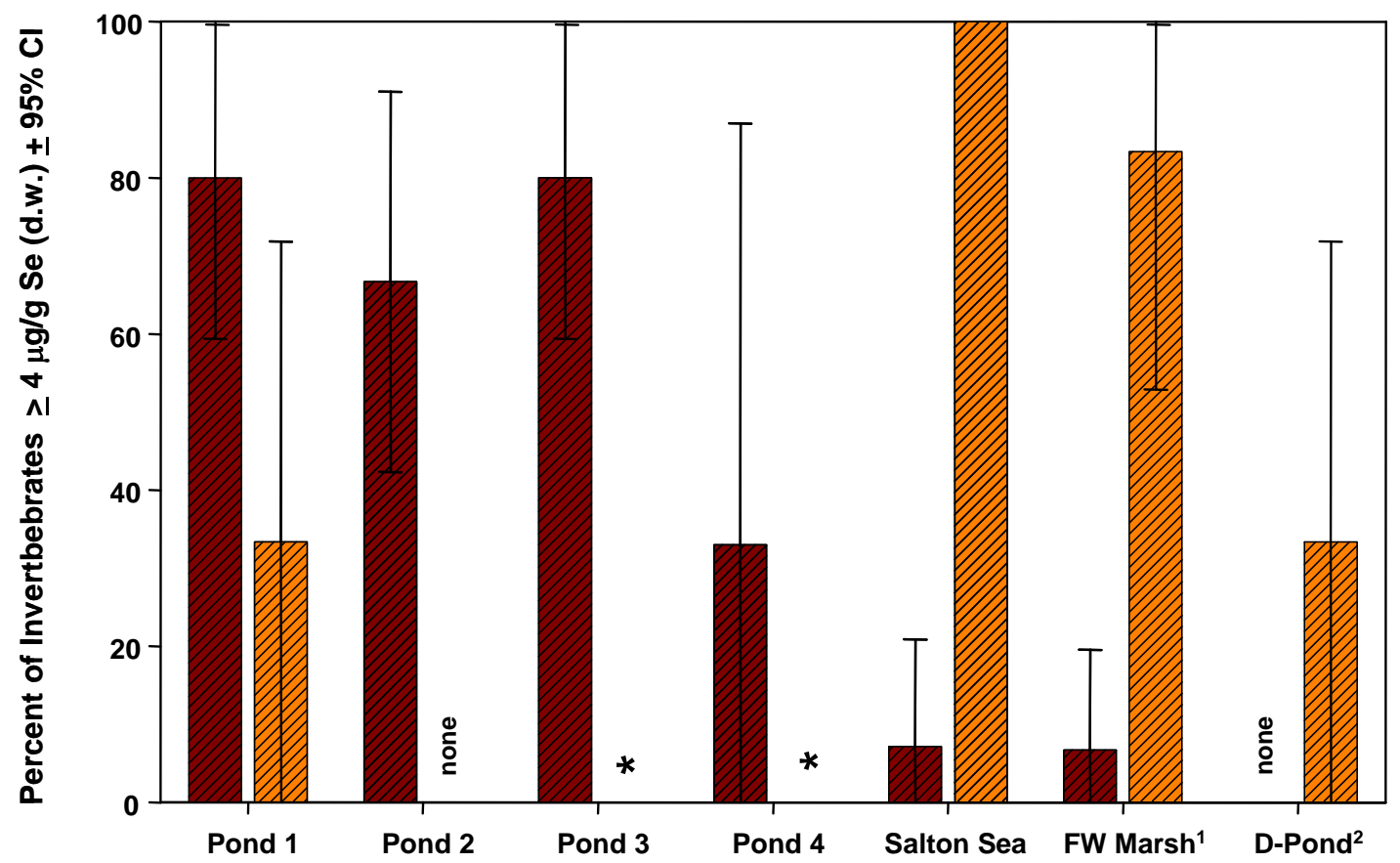

${ }^{1} \mathrm{FW}$ Marsh = Freshwater Marsh.

${ }^{2}$ Hazard Pond sampled due to lack of water in D-pond during fall 2008.

Figure 15. Average percentages (and 95-percent confidence intervals) for Corixidae (red bars) and Chironomidae (orange bars) samples collected from the saline habitat ponds (1-4) and reference sites exceeding selenium toxicity threshold concentrations, Ecosystem Monitoring Project, Salton Sea, California, fall 2006-fall 2008. Asterisks indicate taxa were not present, 'none' indicates no samples exceeded the toxicity threshold. Pond 4 was omitted because it only contained Corixidae samples in fall 2006. 
- SHP O REF
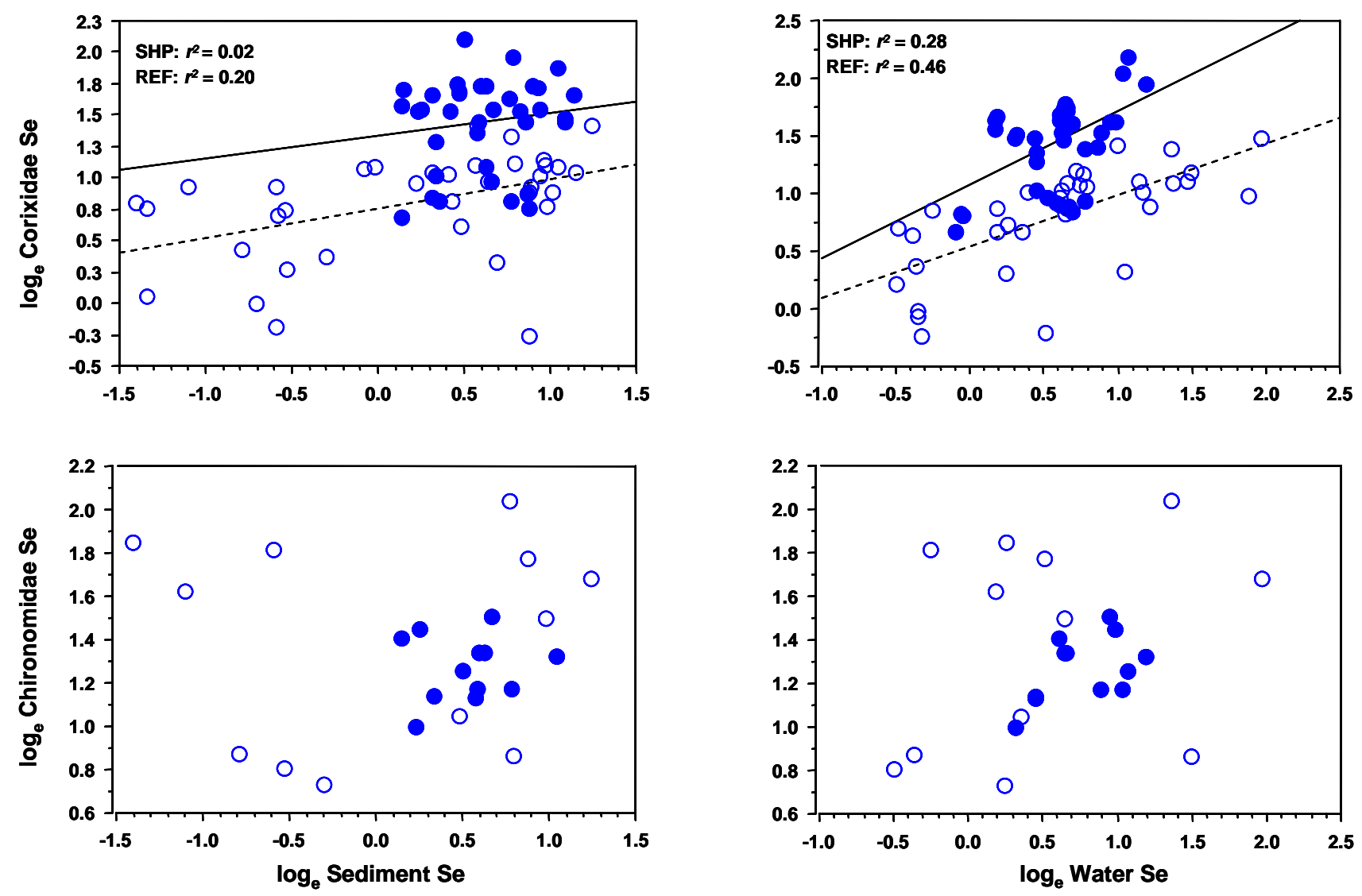

${ }^{1}$ FW Marsh = Freshwater Marsh, Hazard Pond sampled due to lack of water in D-pond during fall 2008.

Figure 16. Relationships between natural log transformed selenium concentrations ( $\mu \mathrm{g} / \mathrm{g}, \mathrm{d} w)$ in Corixidae and Chironomidae ( $y$-axis), and water and sediment (x-axis) samples from the saline habitat ponds (SHP, closed symbols) and reference sites (REF, open symbols) ${ }^{1}$, Ecosystem Monitoring Project, Salton Sea, California, spring 2008-fall 2008. Concentrations are adjusted for modeled random effects of site and sampling point. Regression lines are only plotted for significant $(P<0.05)$ relationships. 


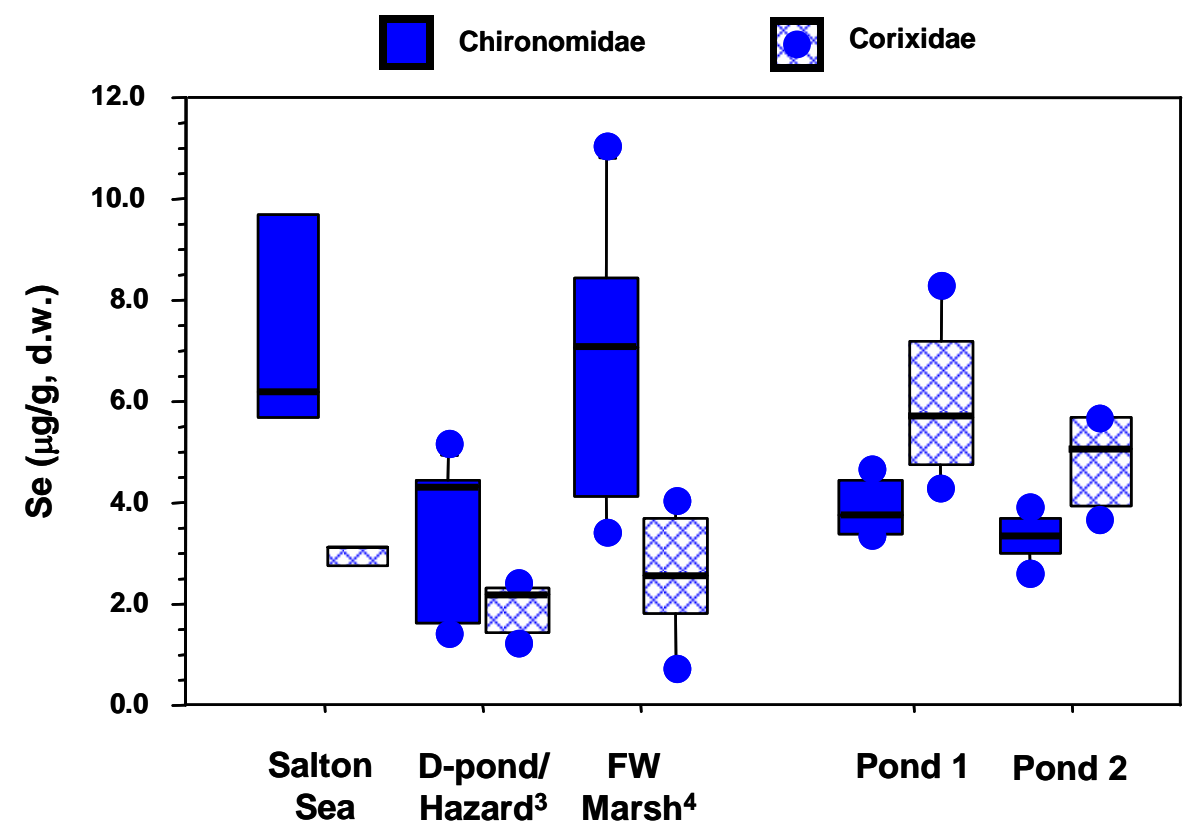

${ }^{1}$ Bold lines within boxes represent median concentration; boxes represent concentrations at the $25^{\text {th }}$ (lower bound) and 75\% (upper bound) percentiles; dots extending from lines below and above boxes represent concentrations at the $10^{\text {th }}$ and $90^{\text {th }}$ percentiles, respectively.

${ }^{2}$ Chironomidae were only present in the Salton Sea during fall 2008, only concentrations from fall 2008 are shown for both taxa at this site. Only the $25^{\text {th }}$ and $75^{\text {th }}$ percentiles (box ends) are displayed because $n=3$ per taxa.

${ }^{3}$ Samples from both taxa in D-Pond and Hazard Pond collected during spring 2008-fall 2008.

${ }^{4}$ FW Marsh $=$ Freshwater Marsh.

Figure 17. Box plots ${ }^{1}$ for selenium concentrations in Corixidae and Chironomidae samples from the saline habitat ponds and reference sites, Ecosystem Monitoring Project, Salton Sea, California, spring 2008-fall 2008. 


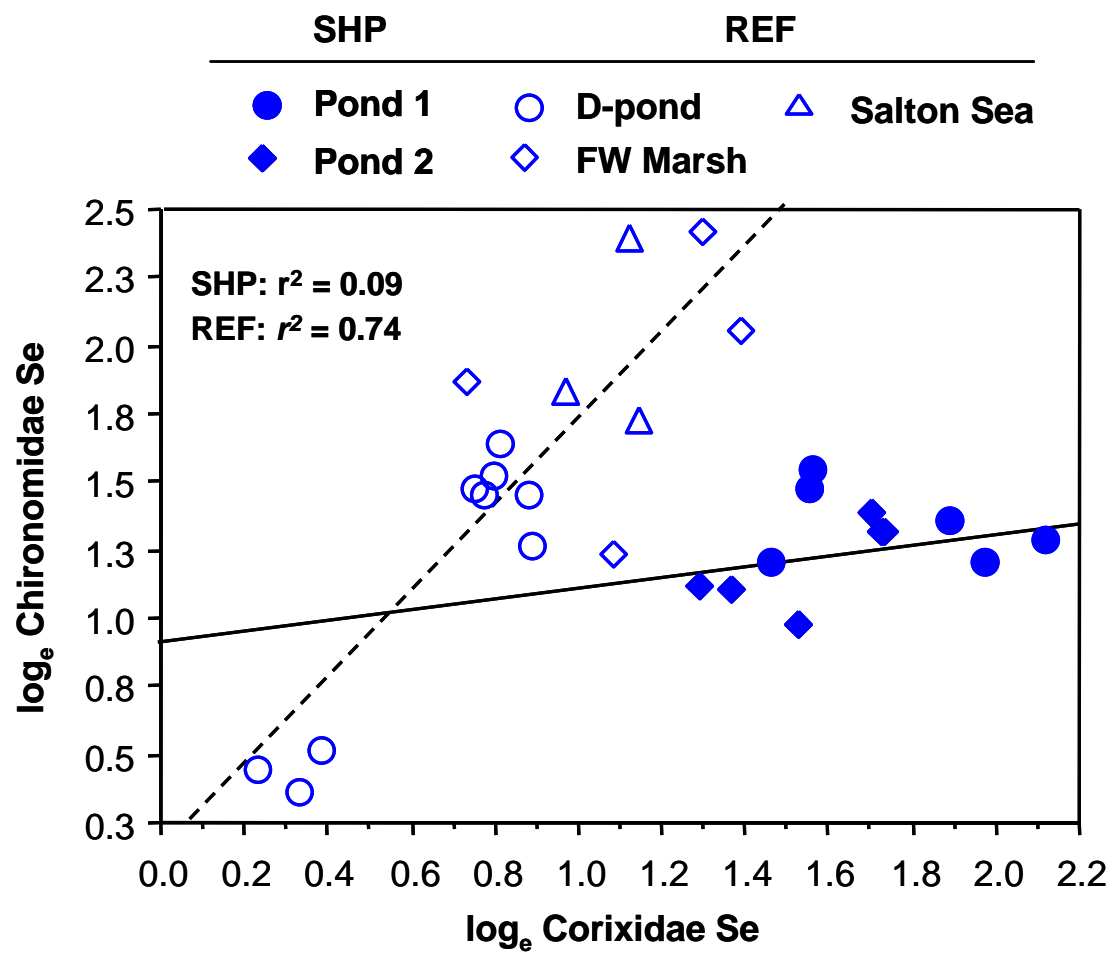

${ }^{1}$ FW Marsh = Freshwater Marsh, Hazard Pond sampled due to lack of water in D-pond during fall 2008.

Figure 18. Relationships between natural log transformed selenium concentrations $(\mu \mathrm{g} / \mathrm{g}, \mathrm{dw})$ in Corixidae and Chironomidae samples from the saline habitat ponds 1 and 2 (SHP, closed symbols) and reference sites (REF, open symbols) ${ }^{1}$, Ecosystem Monitoring Project, Salton Sea, California, spring 2008-fall 2008. 


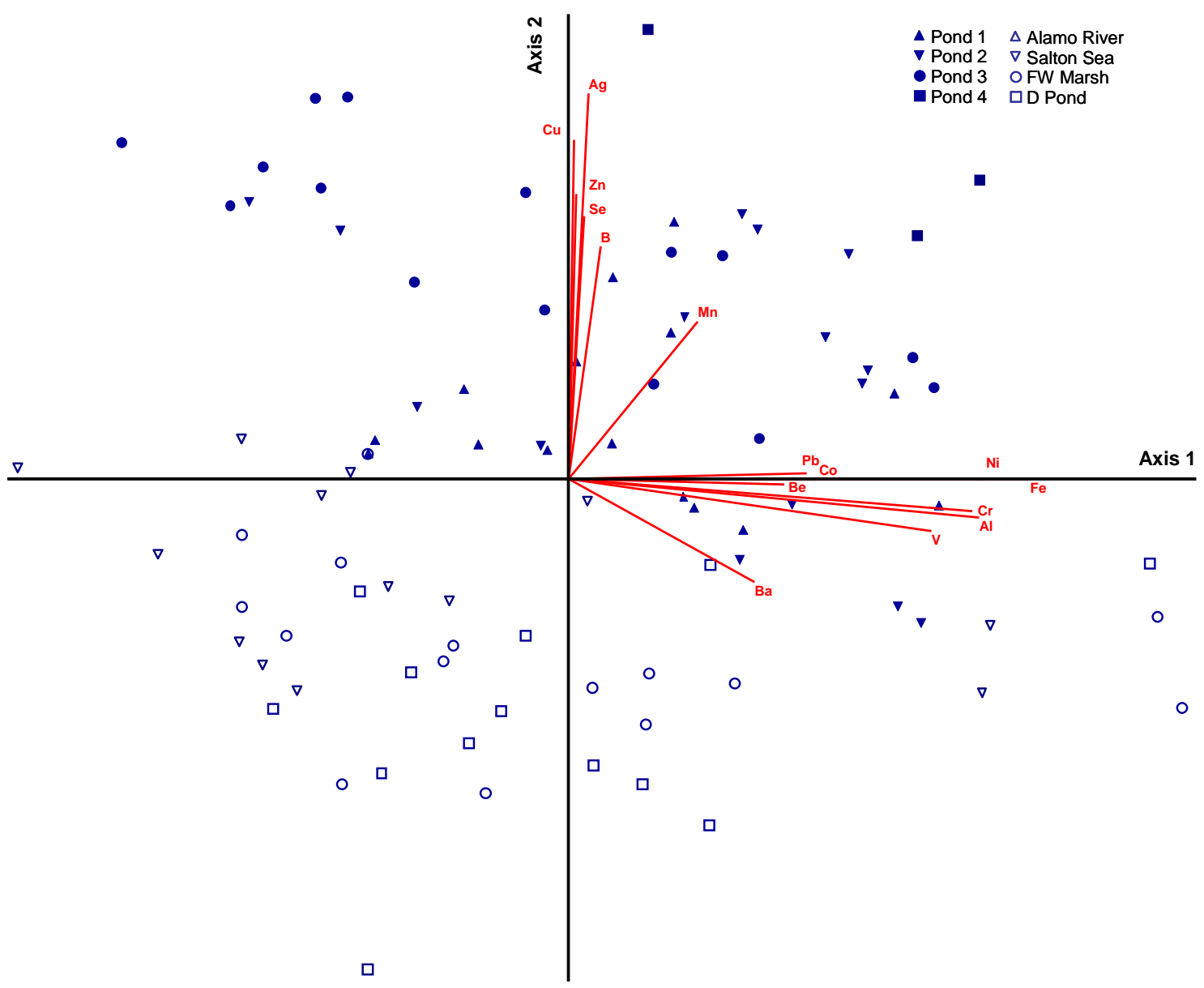

${ }^{1}$ FW Marsh = Freshwater Marsh, Hazard Pond sampled due to lack of water in D-pond during fall 2008.

Figure 19. Principal component analysis ordination of elemental concentrations in Corixidae at the saline habitat ponds (1-4, closed symbols) and reference sites (open symbols) ${ }^{1}$, Ecosystem Monitoring Project, Salton Sea, California, fall 2006-fall 2008. Vectors (red lines) represent strength $\left(R^{2} \geq 0.30\right)$ and direction of elemental loadings in the ordination space. 


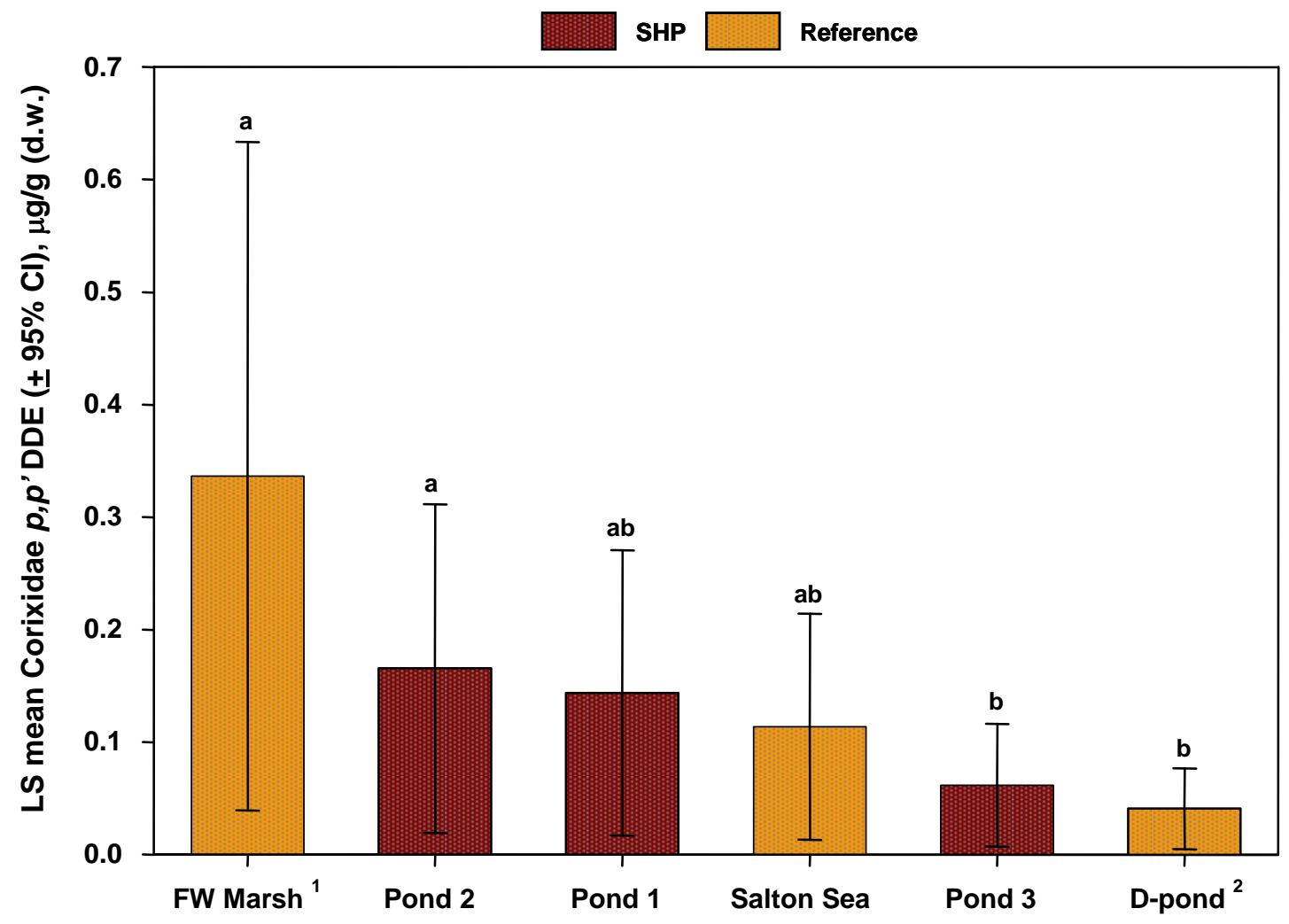

${ }^{1} \mathrm{FW}$ Marsh $=$ Freshwater Marsh.

${ }^{2}$ Hazard Pond sampled due to lack of water in D-pond during fall 2008.

Figure 20. Least-squares means (and 95-percent confidence intervals) for $p, p^{\prime} \mathrm{DDE}$ concentrations in Corixidae samples collected from the saline habitat ponds (1-3, red bars) and reference sites (orange bars), Ecosystem Monitoring Project, Salton Sea, California, fall 2006-fall 2008. Means are ordered from high to low; means sharing the same letter do not differ significantly. 

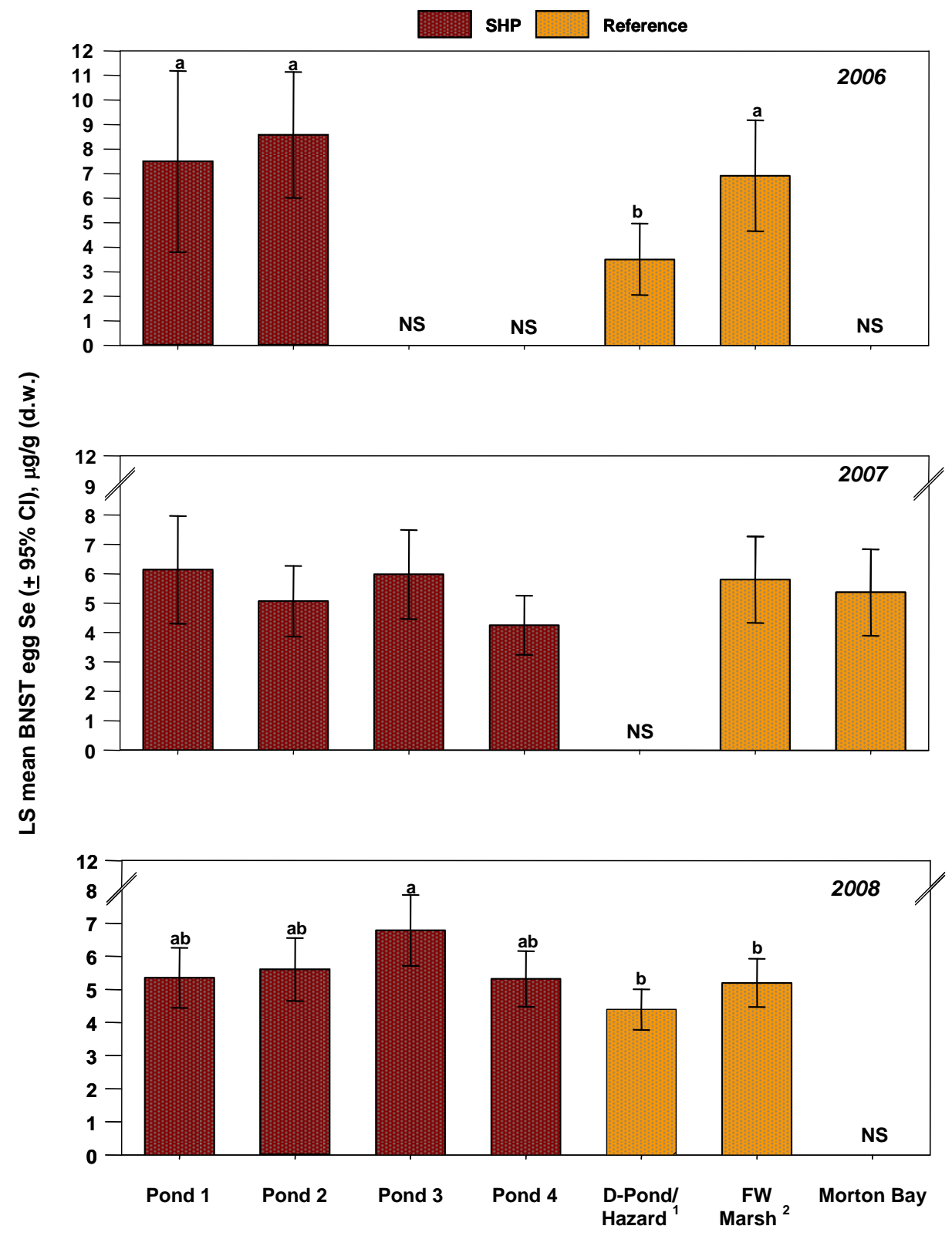

${ }^{1}$ D-Pond sampled during 2006, Hazard sampled during 2008.

${ }^{2}$ FW Marsh $=$ Freshwater Marsh.

Figure 21. Least-squares means (and 95-percent confidence intervals) for selenium concentrations in fresh Black-necked Stilt eggs collected from the saline habitat ponds (1-4, red bars) and reference sites (orange bars) for the Ecosystem Monitoring Project, Salton Sea, California, 2006 (A), 2007 (B), 2008 (C). Means sharing the same letter or means with no letters do not significantly differ. NS denotes 'none sampled'. 


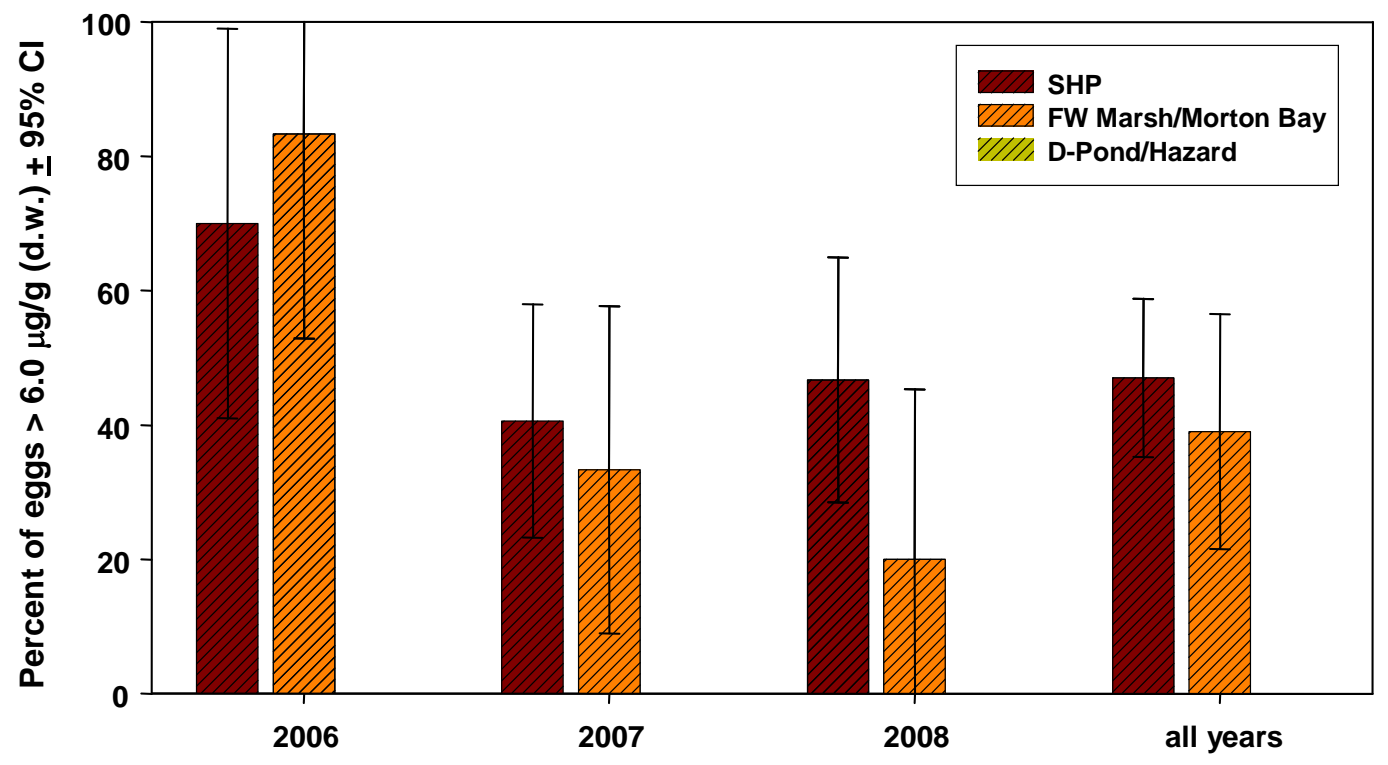

Figure 22. Average percentages (95-percent confidence intervals) of fresh Black-necked Stilt eggs collected from the saline habitat ponds (SHP) and reference sites (Freshwater Marsh/Morton Bay and D-Pond/Hazard) with selenium concentrations exceeding a toxicity threshold of $6.0 \mu \mathrm{g} / \mathrm{g}$ (dry weight), Ecosystem Monitoring Project, Salton Sea, California, 2006-08. No egg sampled from D-Pond or Hazard ponds exceeded the toxicity threshold. FW Marsh = Fresh Water Marsh. 


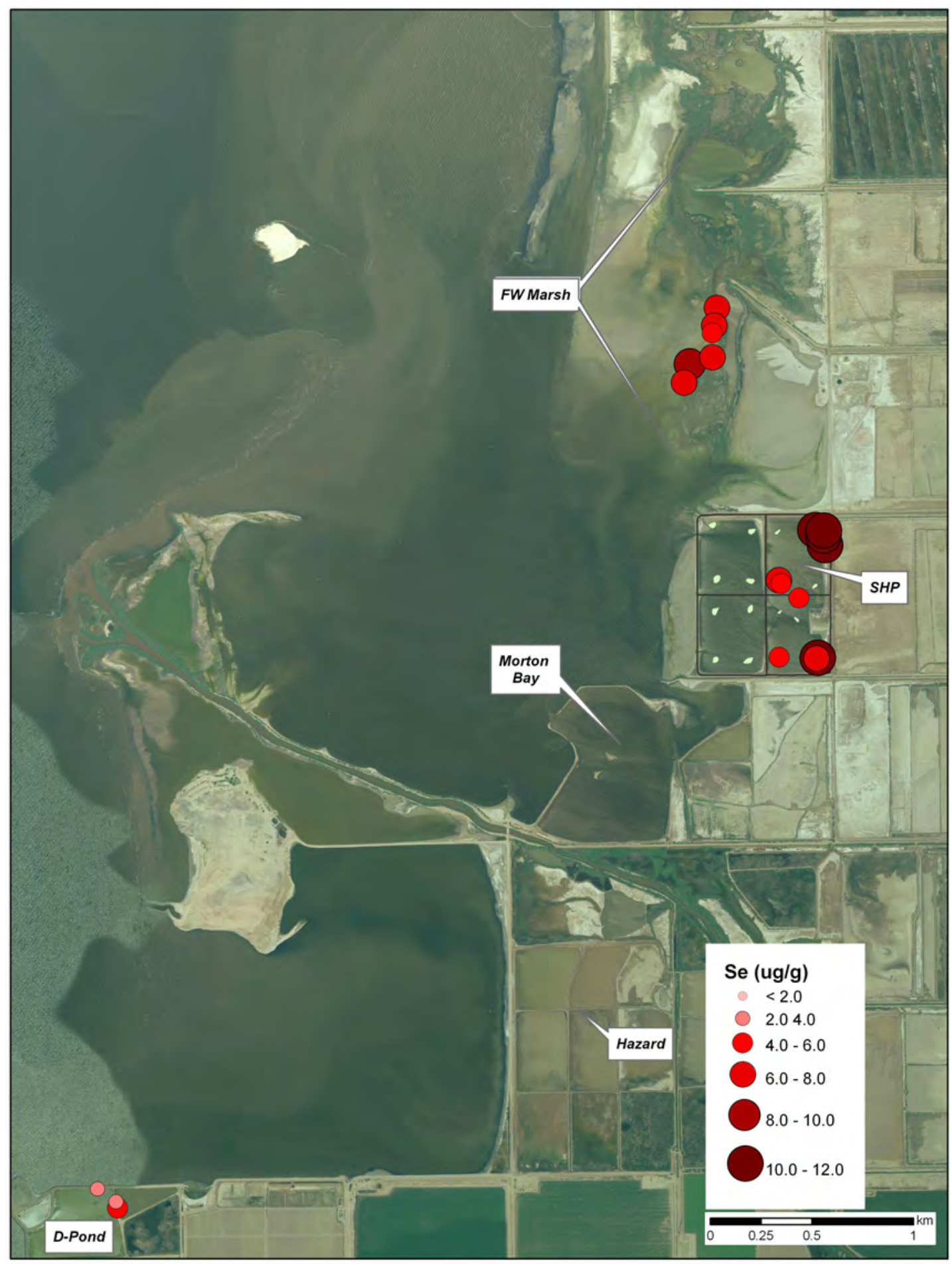

Figure 23A. Spatially explicit selenium concentrations ( $\mu \mathrm{g} / \mathrm{g}$, dry weight) in fresh Black-necked Stilt eggs collected during the 2006 nesting season, Ecosystem Monitoring Project, Salton Sea, California. SHP, saline habitat ponds; FW Marsh, Freshwater Marsh. 


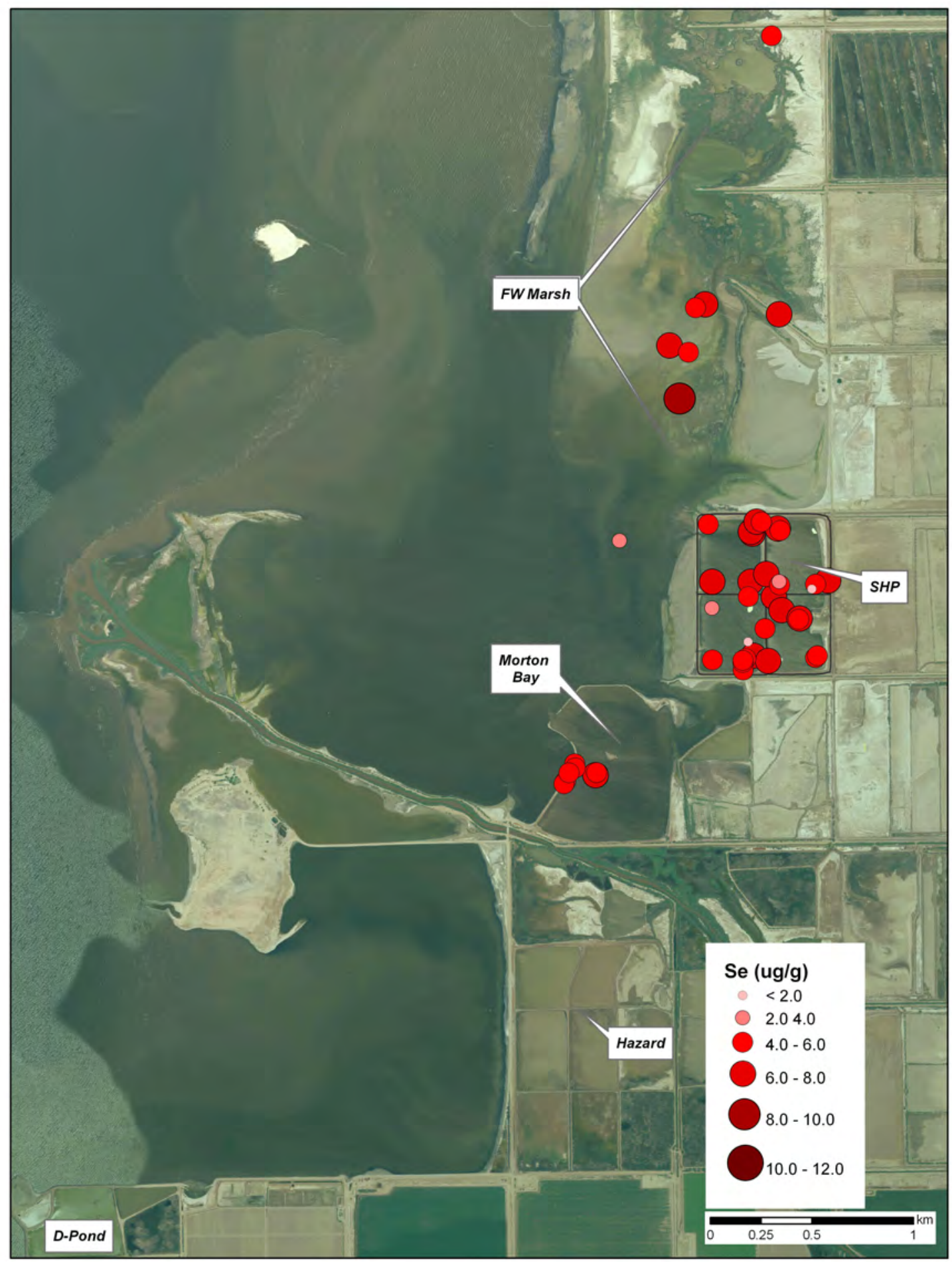

Figure 23B. Spatially explicit selenium concentrations ( $\mu \mathrm{g} / \mathrm{g}$, dry weight) in fresh Black-necked Stilt eggs collected during the 2007 nesting season, Ecosystem Monitoring Project, Salton Sea, California. SHP, saline habitat ponds; FW Marsh, Freshwater Marsh. 


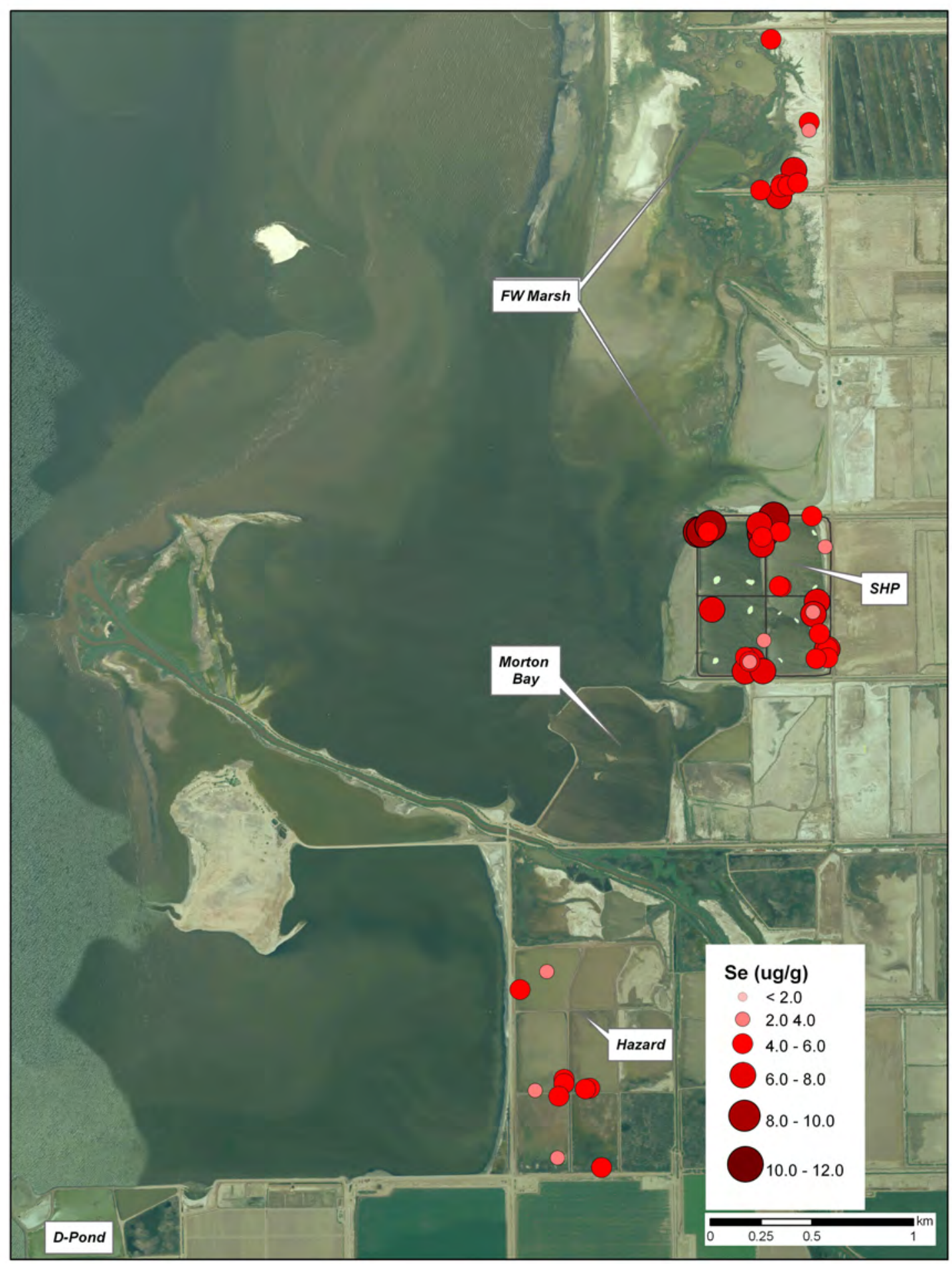

Figure 23C. Spatially explicit selenium concentrations ( $\mu \mathrm{g} / \mathrm{g}$, dry weight) in fresh black-necked stilt eggs collected during the 2008 nesting season, Ecosystem Monitoring Project, Salton Sea, California. SHP $=$ Saline Habitat Ponds, FW Marsh $=$ Freshwater Marsh . 


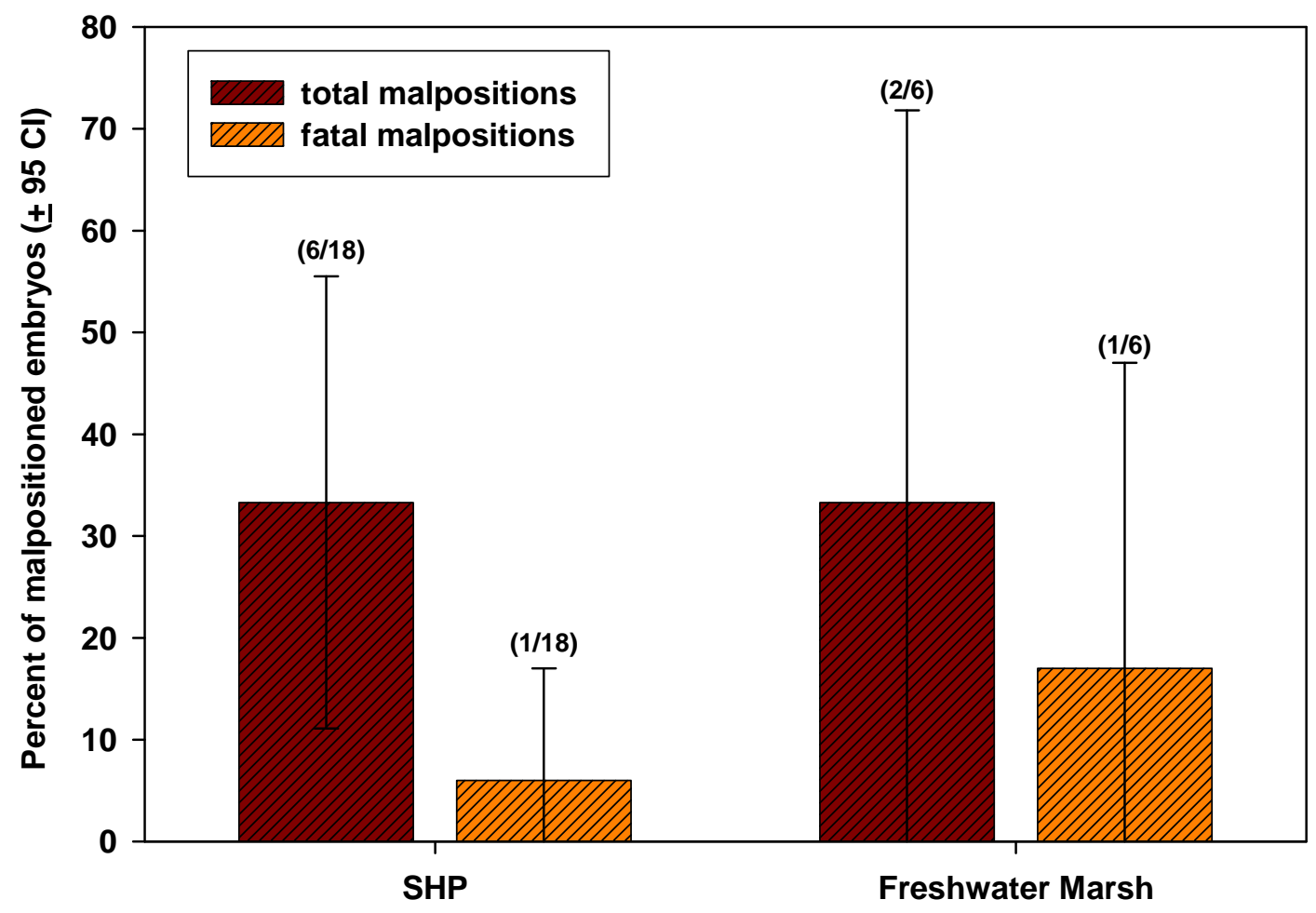

Figure 24. Average percentages (and 95\% confidence intervals) of fresh black-necked stilt eggs collected from the saline habitat ponds (SHP) and reference sites (Freshwater Marsh) containing an embryo malposition (red bars) or a fatal embryo malposition (orange bars), Ecosystem Monitoring Project, Salton Sea, CA, 2006-08. Numbers in parentheses above bars indicate number of eggs containing a malpositioned embryo divided by the total number of eggs containing an embryo greater than or equal to 18 days old. 


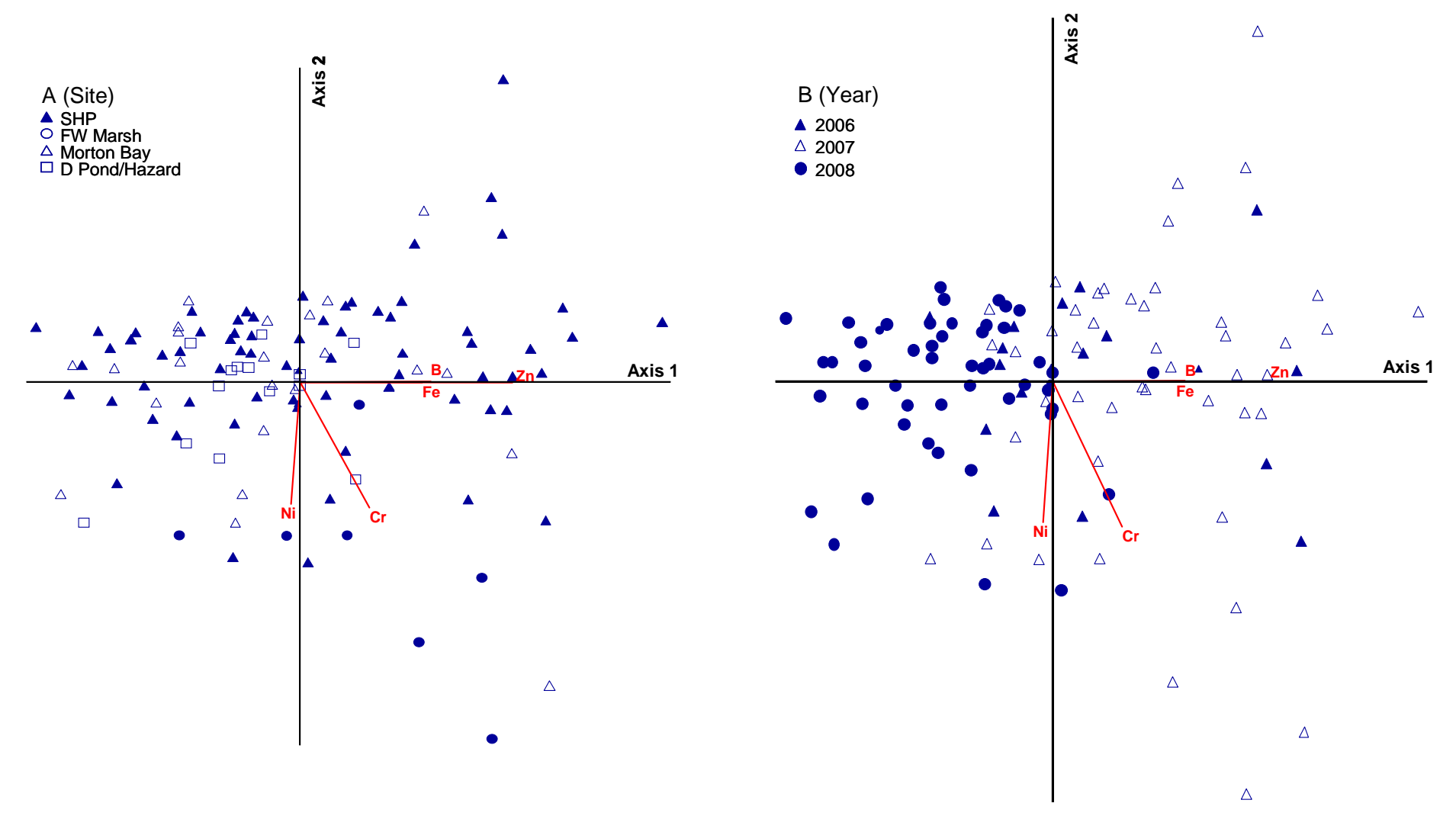

Figure 25. Principal component analysis ordination of elemental concentrations ( $\mu \mathrm{g} / \mathrm{g}$, dry weight) in fresh Black-necked Stilt eggs collected at the saline habitat ponds (SHP) and reference sites by site (A) and year (B), Ecosystem Monitoring Project, Salton Sea, California, 2006-08. Vectors (red lines) represent strength $\left(R^{2} \geq 0.30\right)$ and direction of elemental loadings in the ordination space. FWMarsh, Freshwater Marsh. 


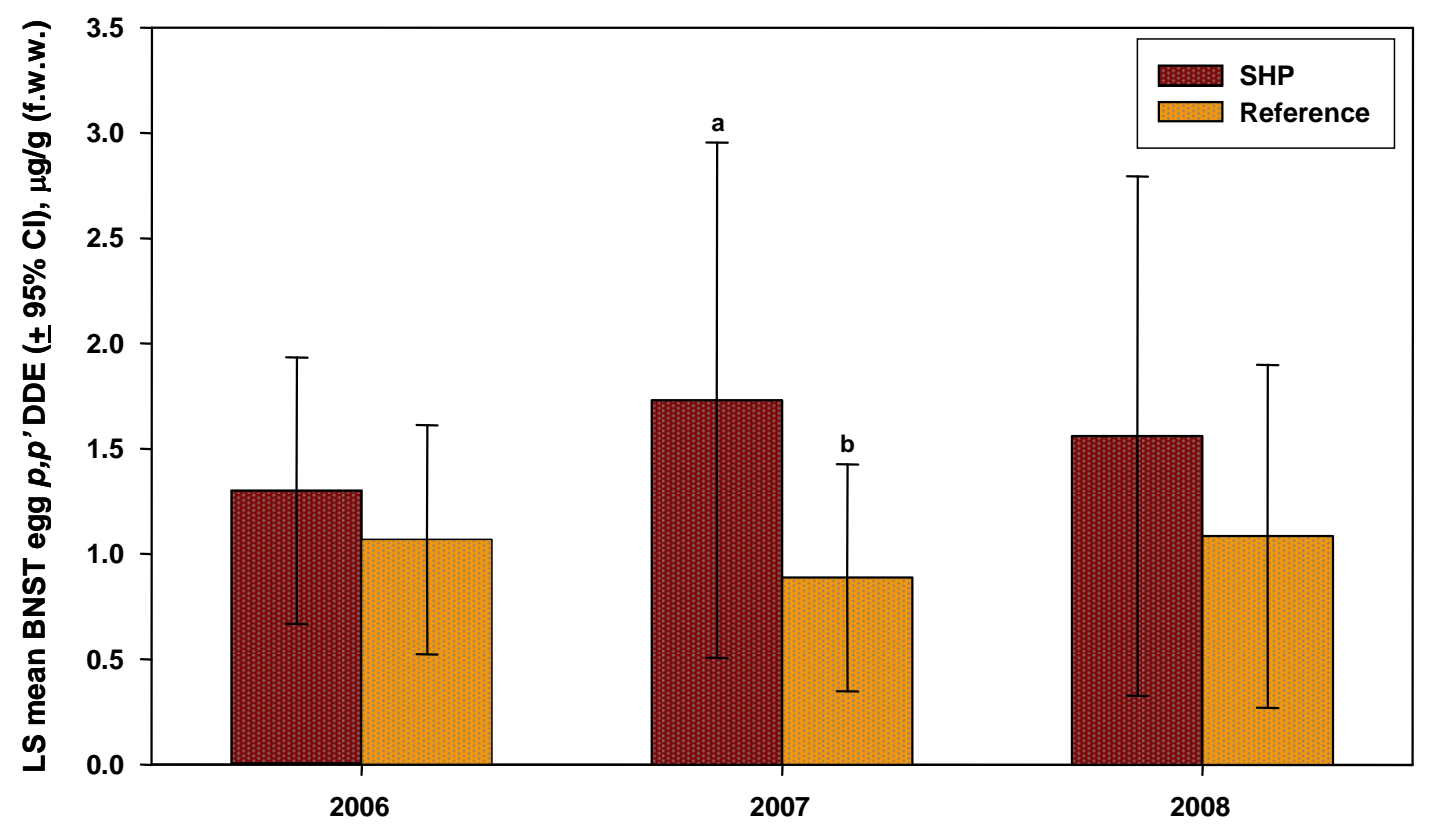

Figure 26. Least-squares means (and 95-percent confidence intervals) for $p, p^{\prime} \mathrm{DDE}$ concentrations in fresh Black-necked Stilt eggs collected from the saline habitat ponds (SHP, red bars) and reference sites (orange bars), Ecosystem Monitoring Project, Salton Sea, California, 2006-08. Means sharing the same letter or means with no letters do not differ significantly. 


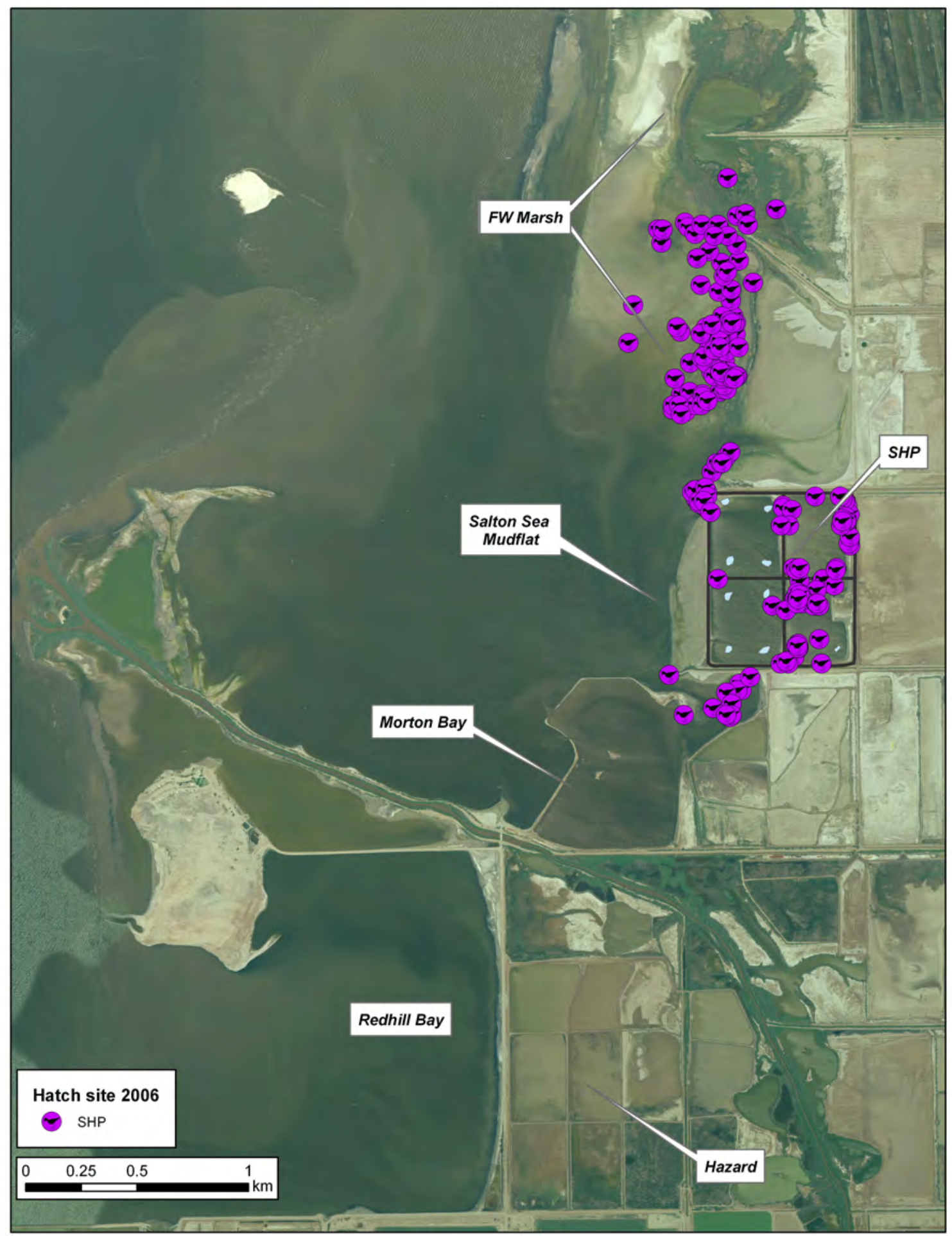

Figure 27A. Locations for radio-marked Black-necked Stilt chicks hatched at the saline habitat ponds (SHP) detected alive during the 2006 nesting season, Ecosystem Monitoring Project, Salton Sea, California. FW Marsh, Freshwater Marsh. 


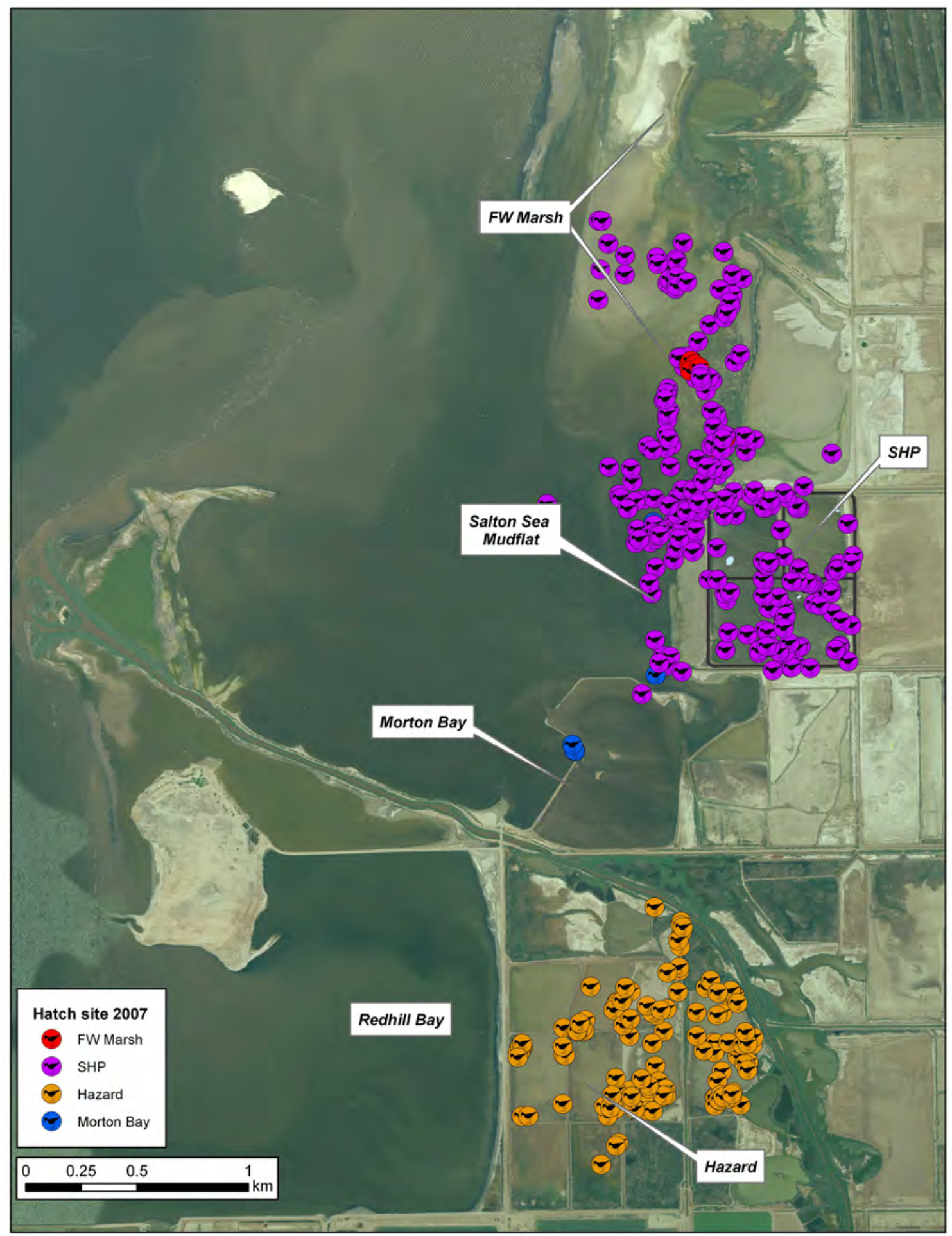

Figure 27B. Locations for radio-marked Black-necked Stilt chicks detected alive during the 2007 nesting season, Ecosystem Monitoring Project, Salton Sea, California. Locations for chicks hatched at different sites are color coded. SHP, saline habitat ponds; FW Marsh, Freshwater Marsh. 


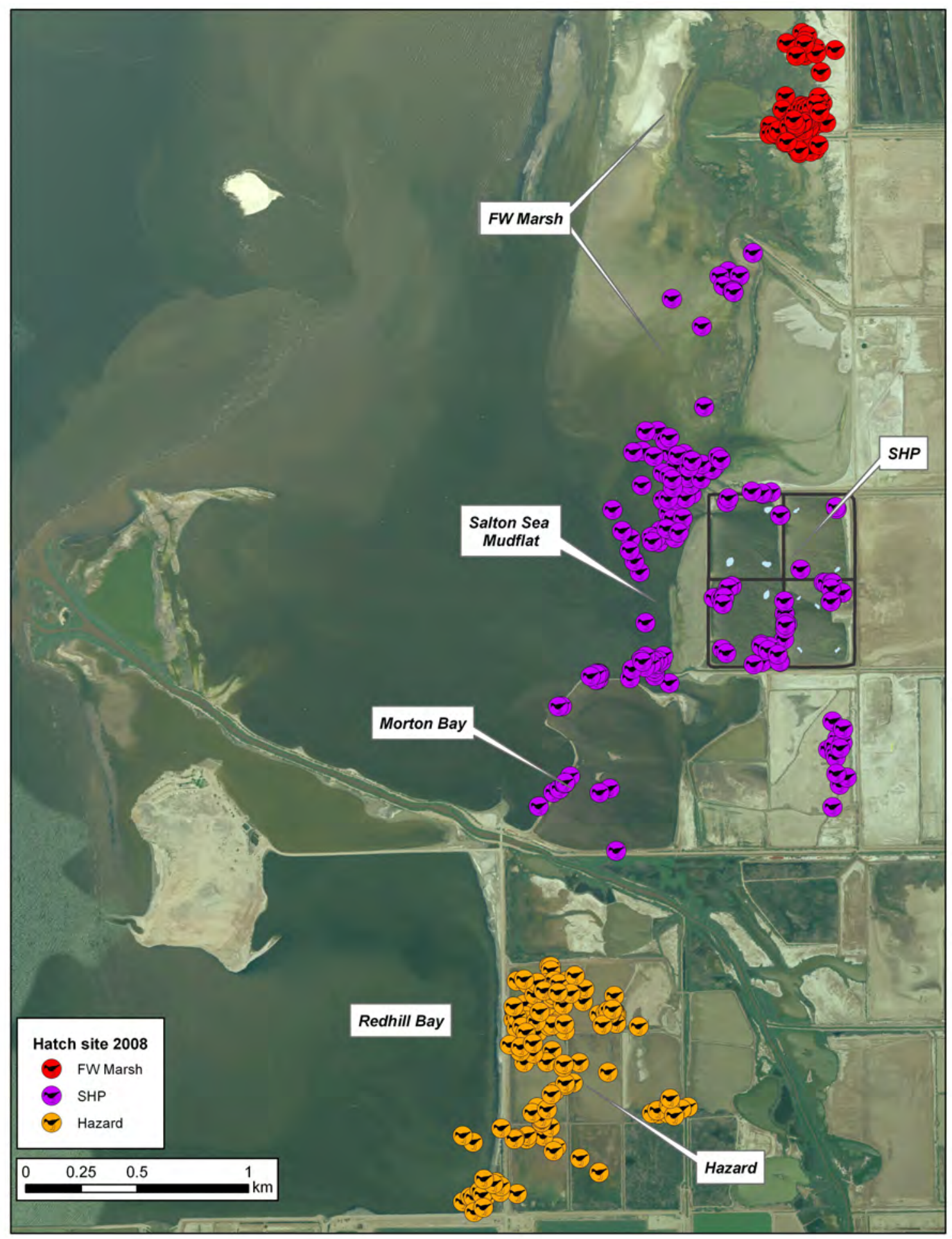

Figure 27C. Locations for radio-marked black-necked stilt chicks detected alive during the 2008 nesting season, Ecosystem Monitoring Project, Salton Sea, California. Locations for chicks hatched at different sites are color coded. SHP, saline habitat ponds; FW Marsh, Freshwater Marsh. 


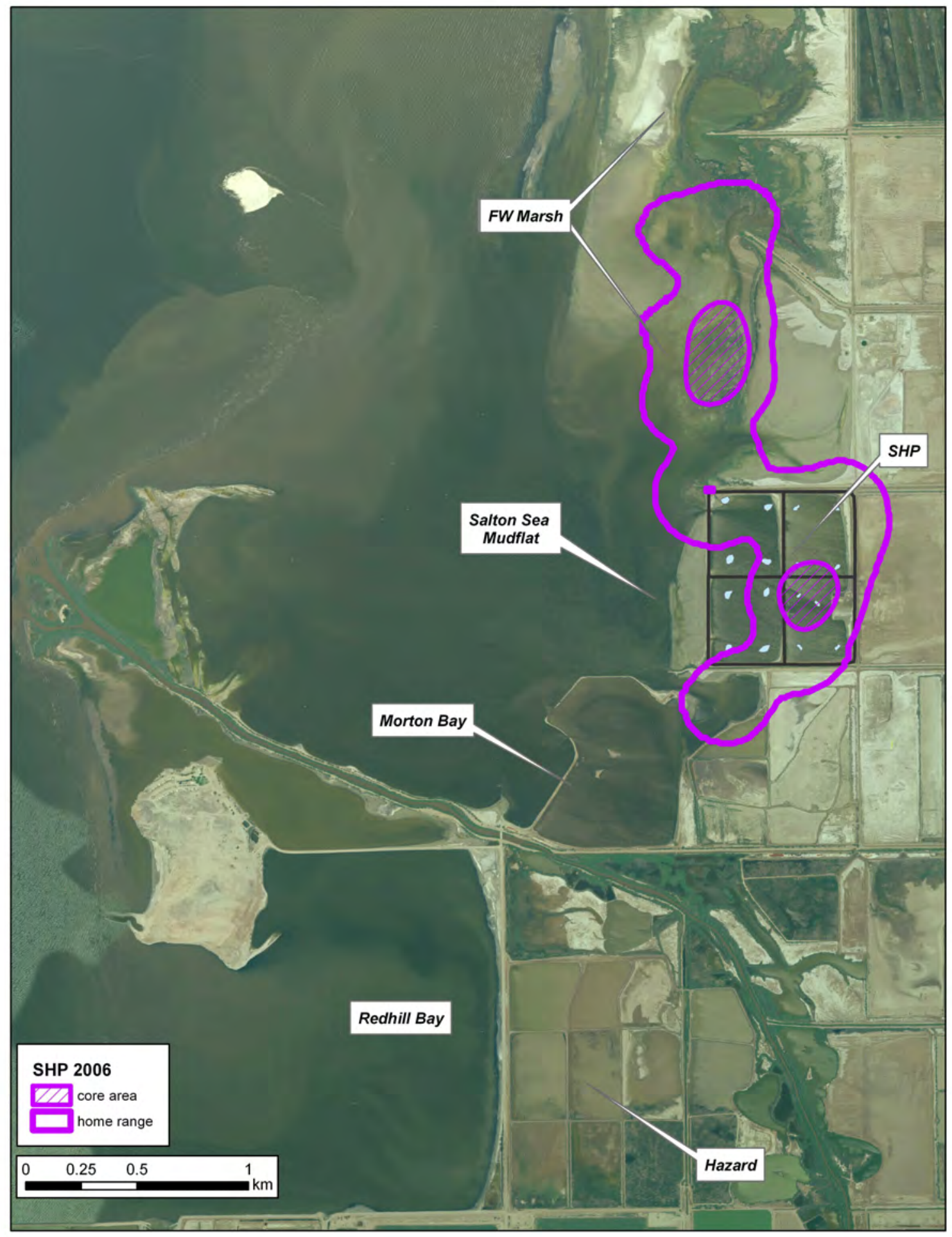

Figure 28A. Estimated 95\% (home range) and 50\% (core area) utilization distributions for populations of radio-marked Black-necked Stilt chicks during the 2006 nesting season, Ecosystem Monitoring Project, Salton Sea, California. SHP, saline habitat ponds; FW Marsh, Freshwater Marsh. 


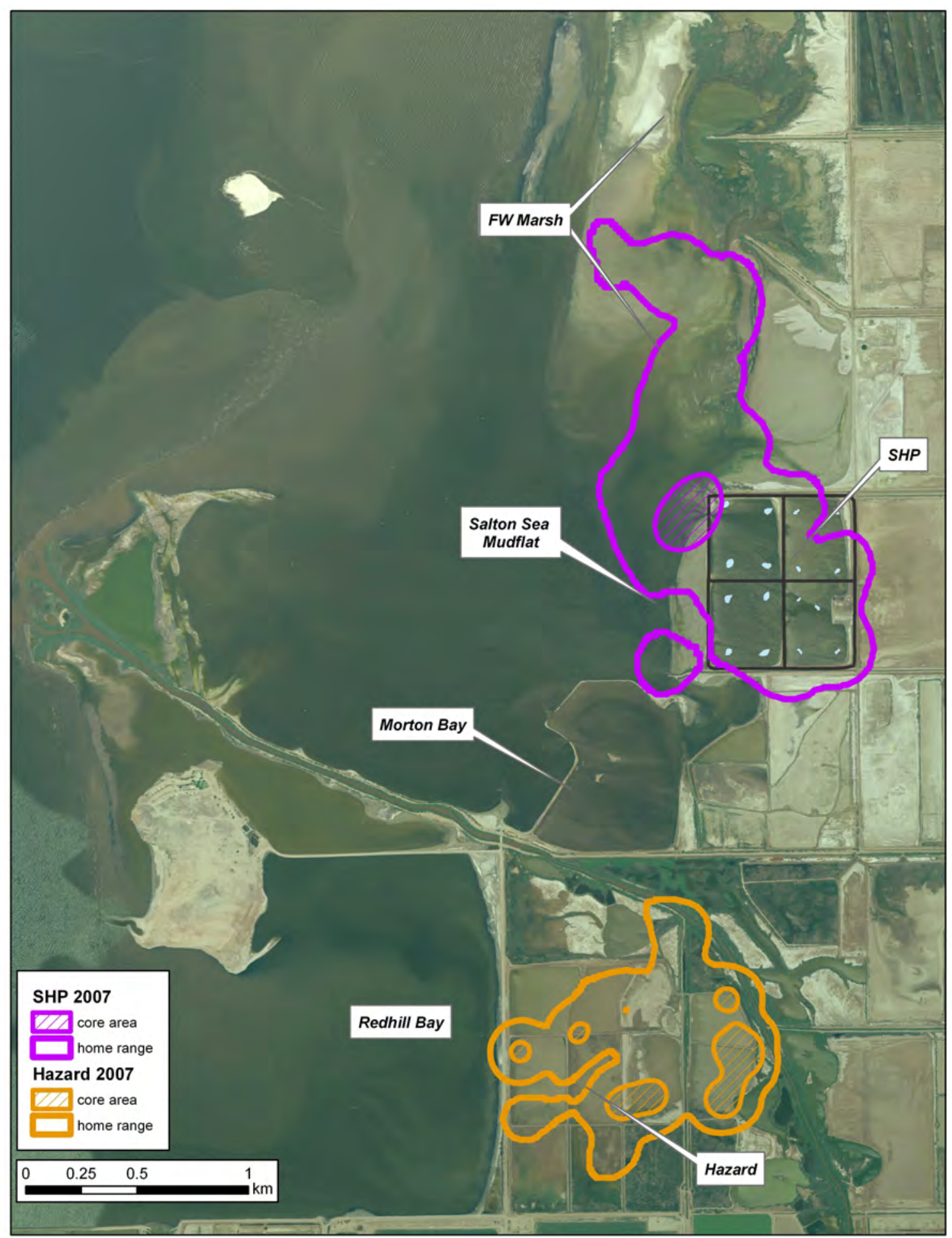

Figure 28B. Estimated 95\% (home range) and 50\% (core area) utilization distributions for populations of radio-marked Black-necked Stilt chicks during the 2007 nesting season, Ecosystem Monitoring Project, Salton Sea, California. SHP, saline habitat ponds; FW Marsh, Freshwater Marsh. 


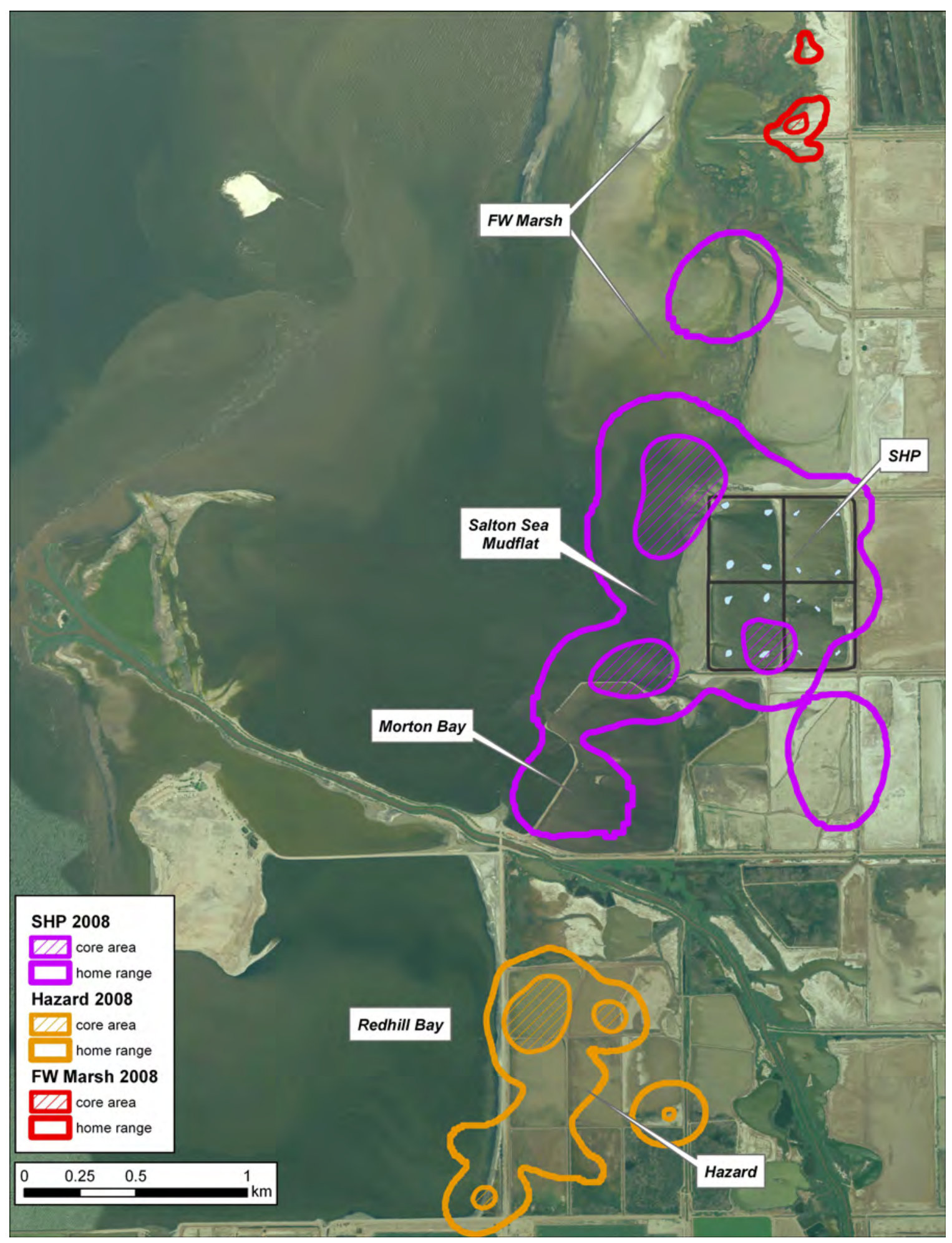

Figure 28C. Estimated 95\% (home range) and 50\% (core area) utilization distributions for populations of radio-marked Black-necked Stilt chicks during the 2008 nesting season, Ecosystem Monitoring Project, Salton Sea, California. SHP, saline habitat ponds; FW Marsh, Freshwater Marsh. 

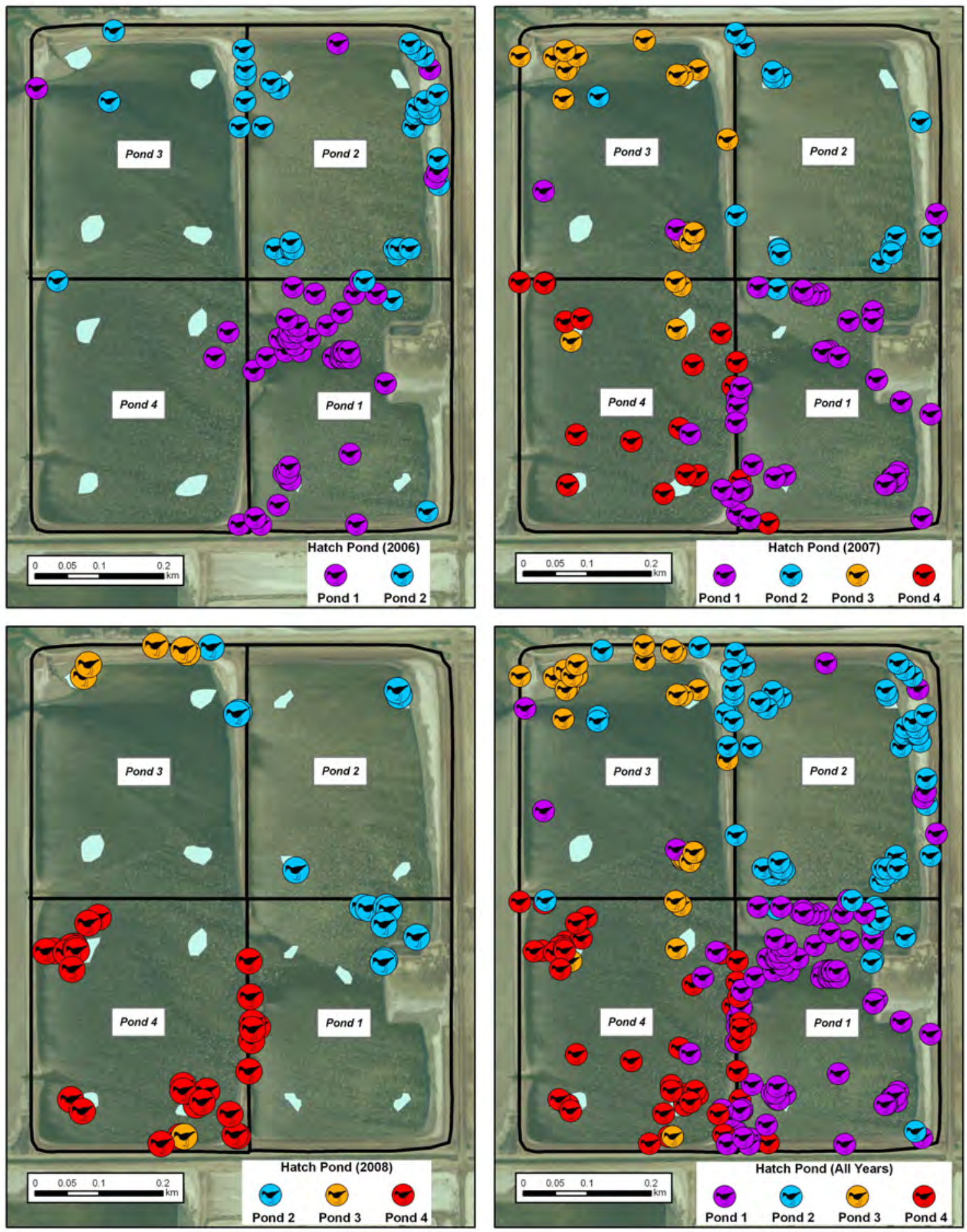

Figure 29. Inter-pond movements for radio-marked black-necked stilt chicks hatched at the saline habitat ponds (SHP) during the 2006-08 nesting seasons, Ecosystem Monitoring Project, Salton Sea, California. Locations for chicks hatched within particular SHP ponds are color coded. 


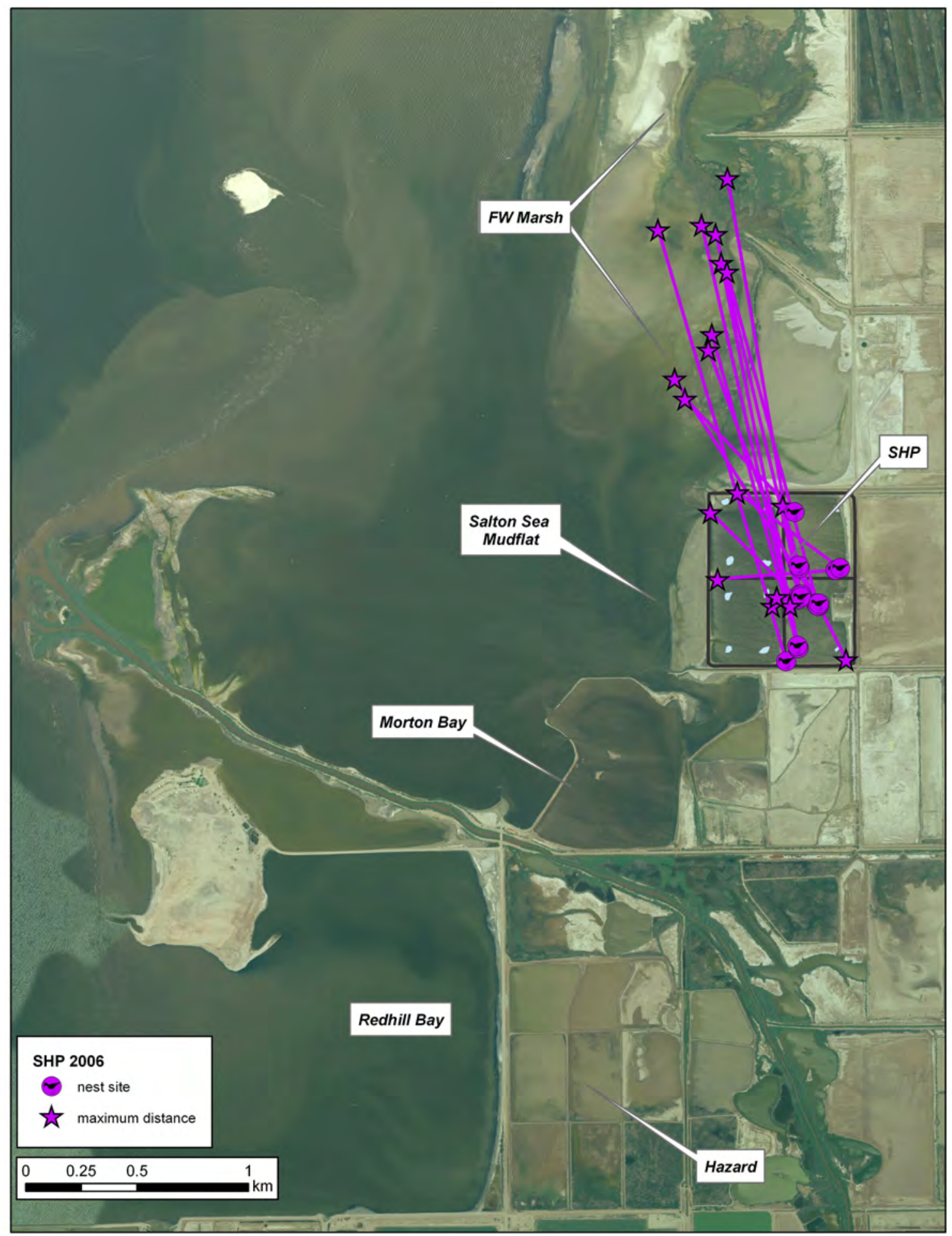

Figure 30A. Maximum distance and direction traveled from nest sites for Black-necked Stilt chicks radio-marked during the 2006 nesting season, Ecosystem Monitoring Project, Salton Sea, California. SHP, saline habitat ponds; FW Marsh, Freshwater Marsh. 


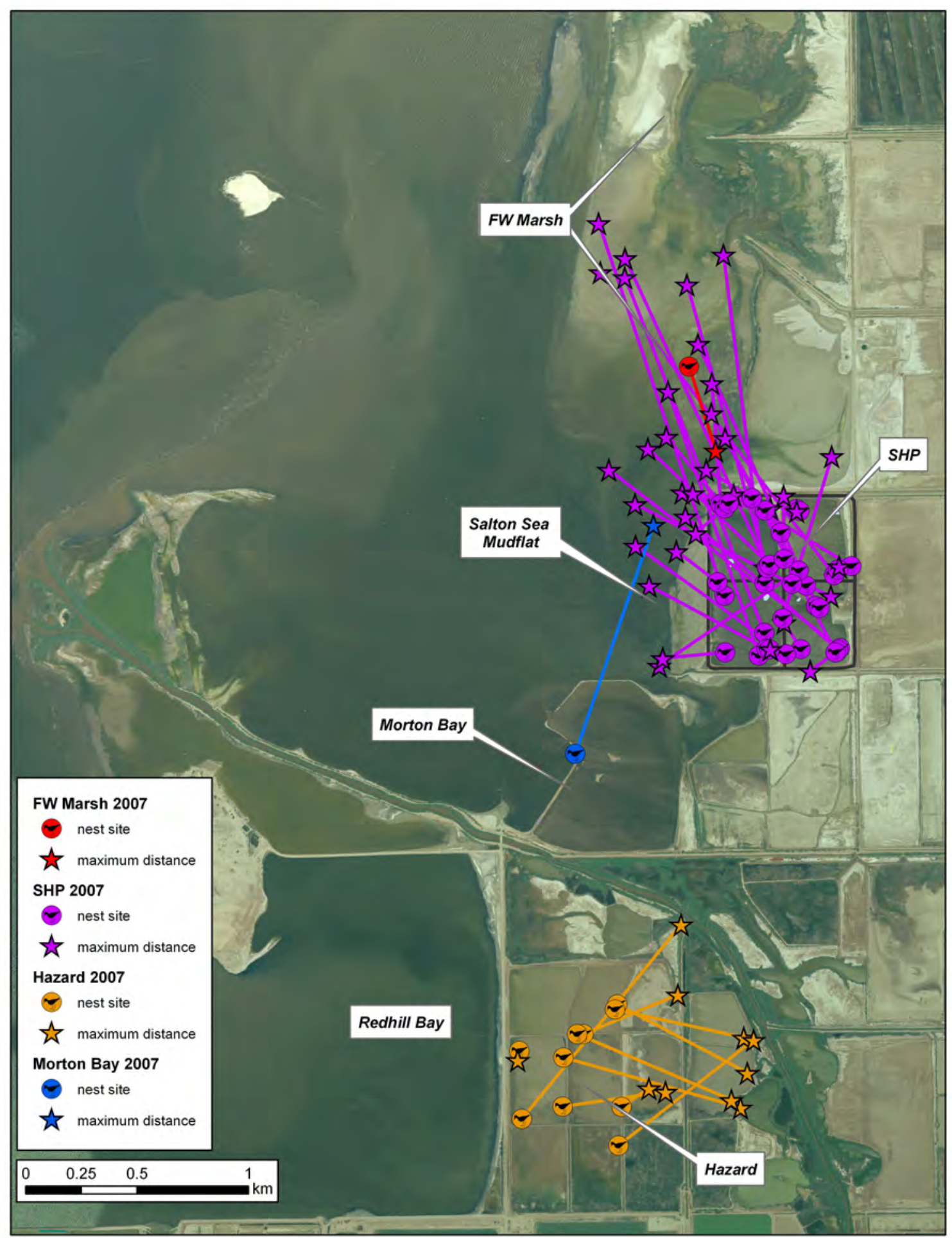

Figure 30B. Maximum distance and direction traveled from nest sites for Black-necked Stilt chicks radio-marked during the 2007 nesting season, Ecosystem Monitoring Project, Salton Sea, California. SHP, saline habitat ponds; FW Marsh, Freshwater Marsh. 


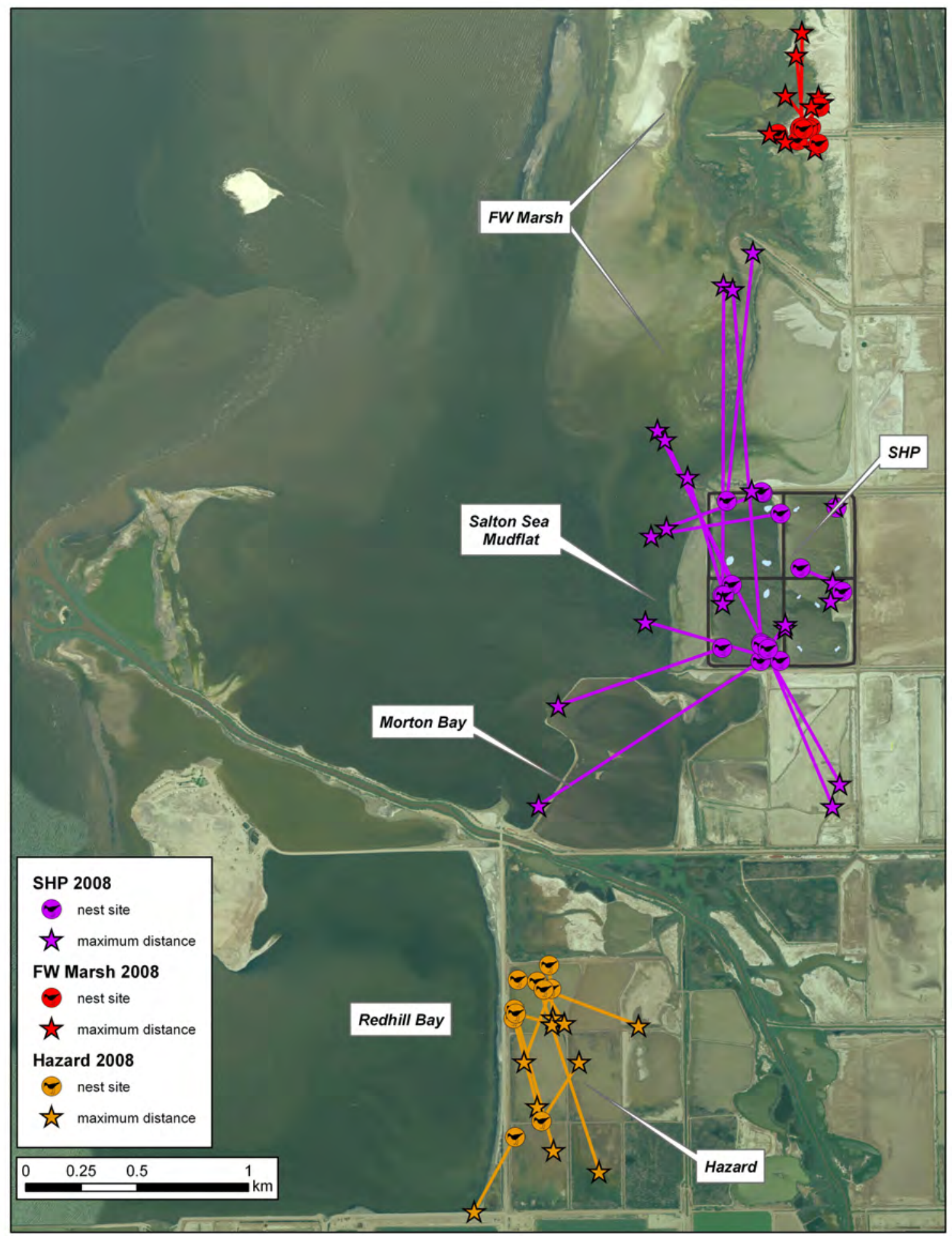

Figure 30C. Maximum distance and direction traveled from nest sites for Black-necked Stilt chicks radio-marked during the 2008 nesting season, Ecosystem Monitoring Project, Salton Sea, California. SHP, saline habitat ponds; FW Marsh, Freshwater Marsh. 

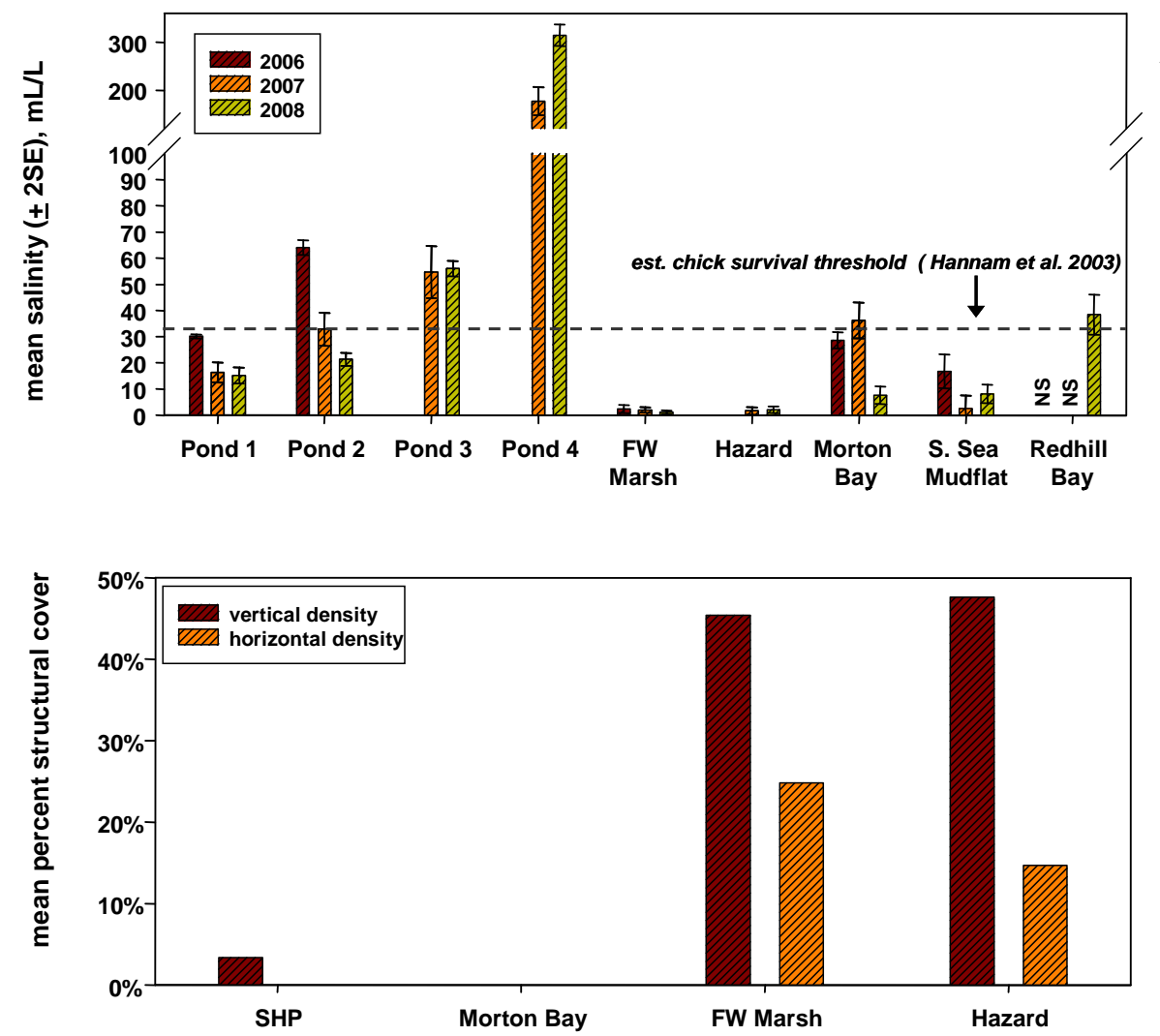

B

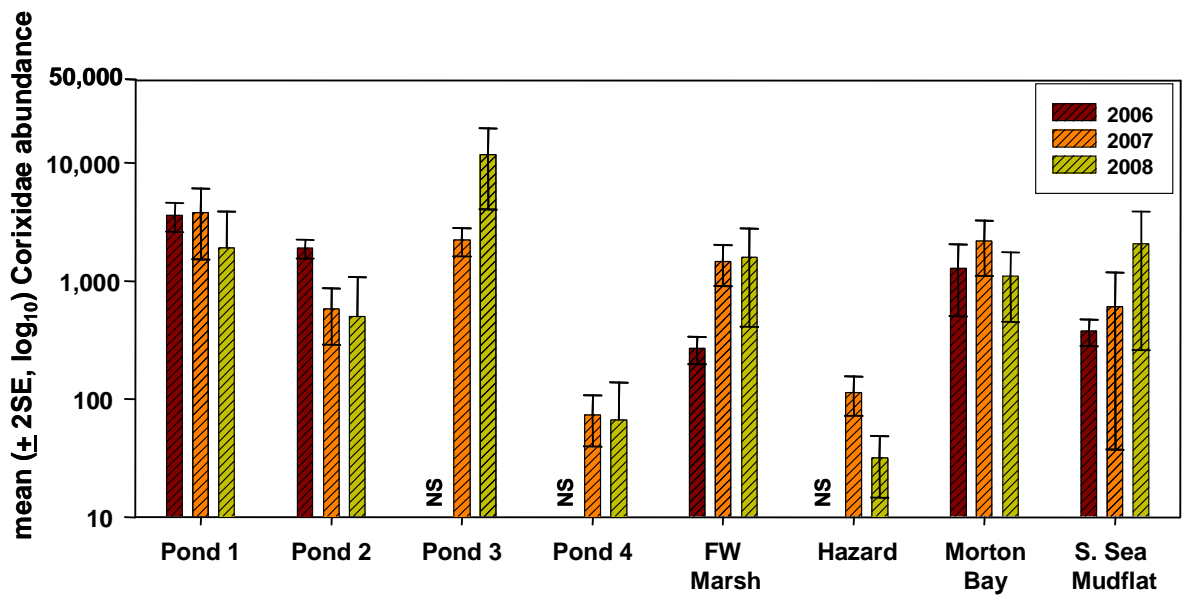

${ }^{1}$ Enumeration of Corixidae abundance from 2008 is ongoing at the time of this report

Figure 31. Measurements for water salinity (A), structural cover (B), and prey (Corixidae) abundance $^{1}(C)$ in habitats occupied by radio-marked black-necked stilt chicks during the 2006 , 2007, or 2008 nesting seasons, Ecosystem Monitoring Project, Salton Sea, California. Structural cover was only measured during 2008, prey abundance is reported for 2006-07. SHP, saline habitat ponds; FW Marsh, Freshwater Marsh. 


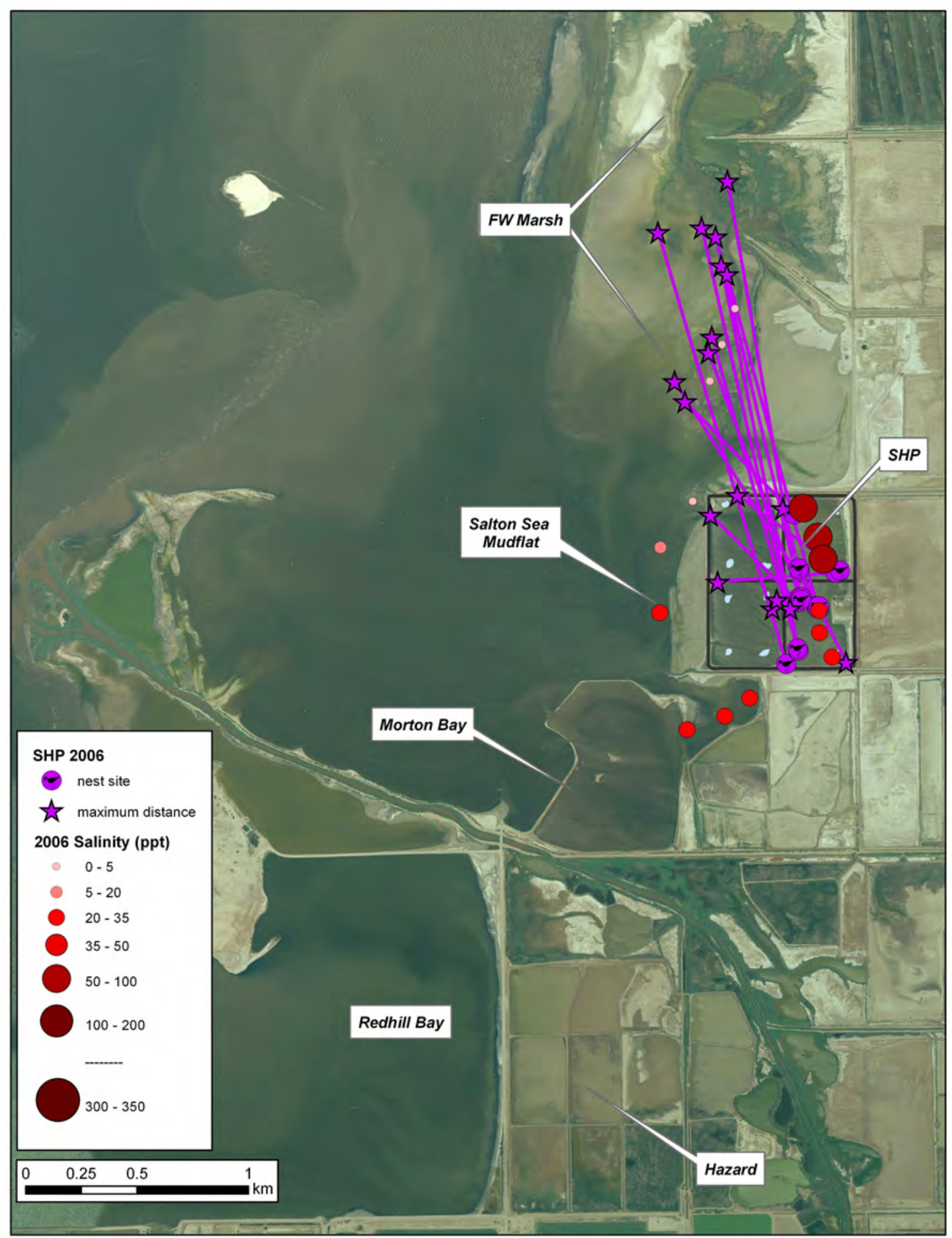

Figure 32A. Maximum distance and direction traveled from nest sites for Black-necked Stilt chicks radio-marked during the 2006 nesting season relative to average water salinity, Ecosystem Monitoring Project, Salton Sea, California. SHP, saline habitat ponds; FW Marsh, Freshwater Marsh. 


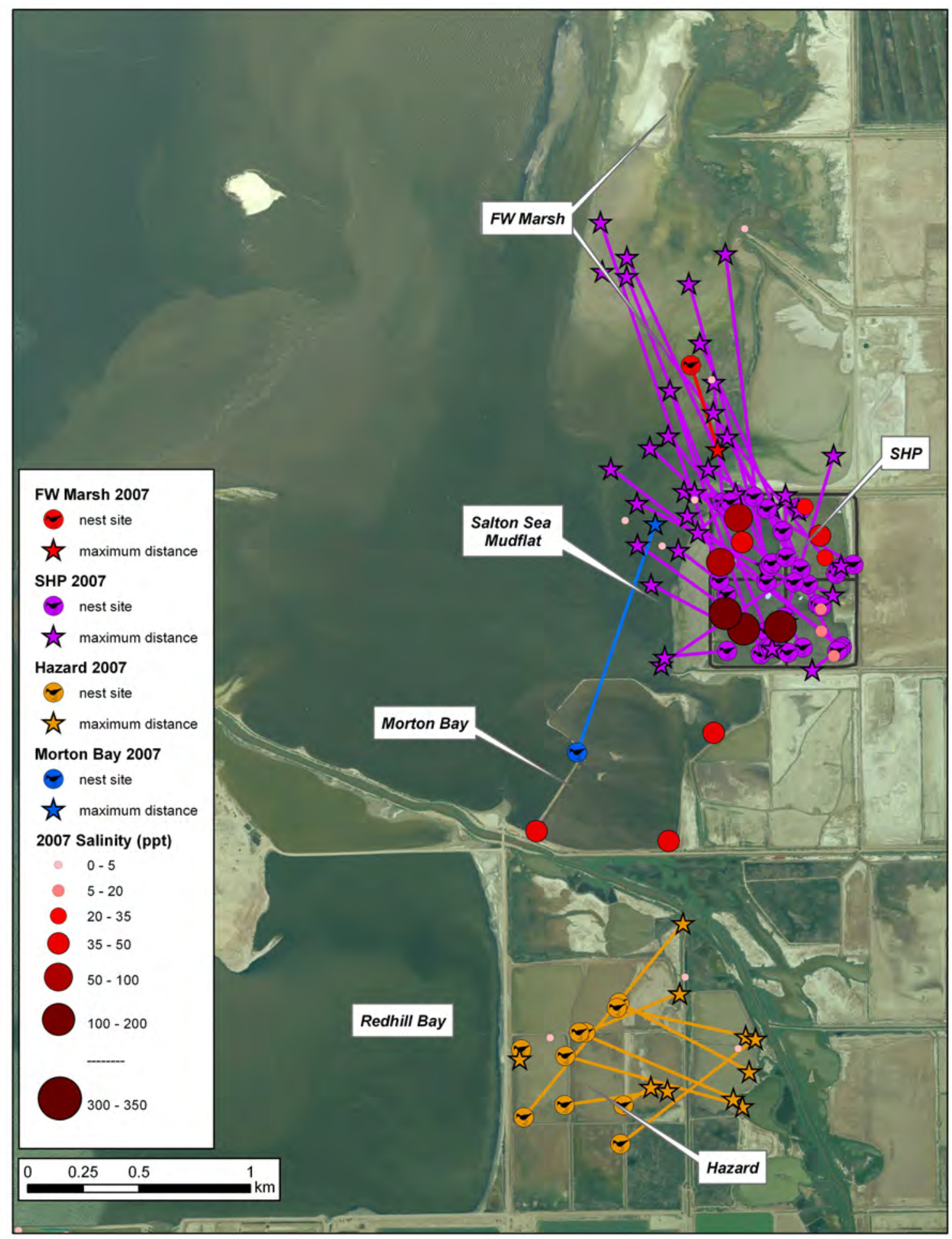

Figure 32B. Maximum distance and direction traveled from nest sites for Black-necked Stilt chicks radio-marked during the 2007 nesting season relative to average water salinity, Ecosystem Monitoring Project, Salton Sea, California. SHP, saline habitat ponds; FW Marsh, Freshwater Marsh. 


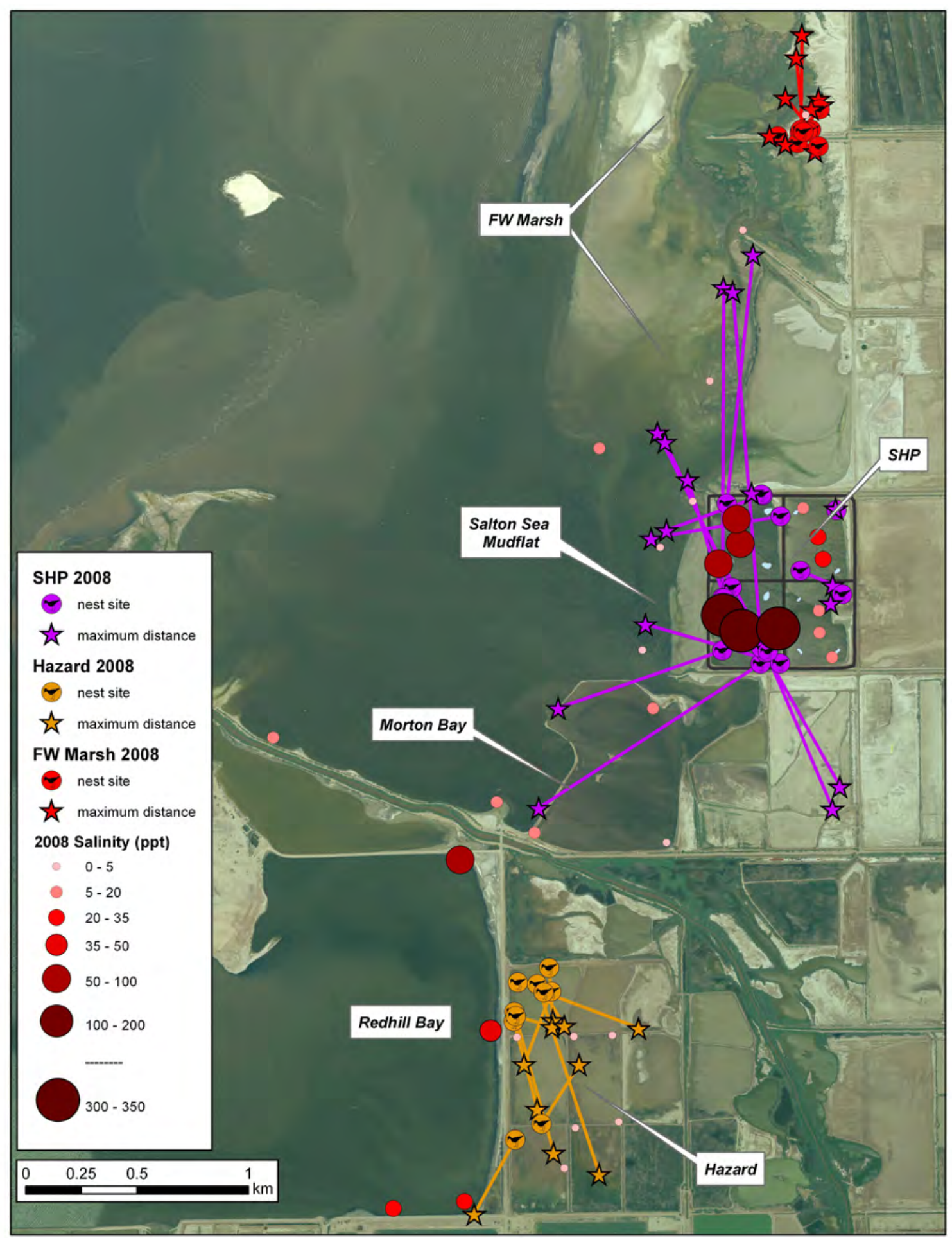

Figure 32C. Maximum distance and direction traveled from nest sites for Black-necked Stilt chicks radio-marked during the 2008 nesting season relative to average water salinity, Ecosystem Monitoring Project, Salton Sea, California. SHP, saline habitat ponds; FW Marsh, Freshwater Marsh. 


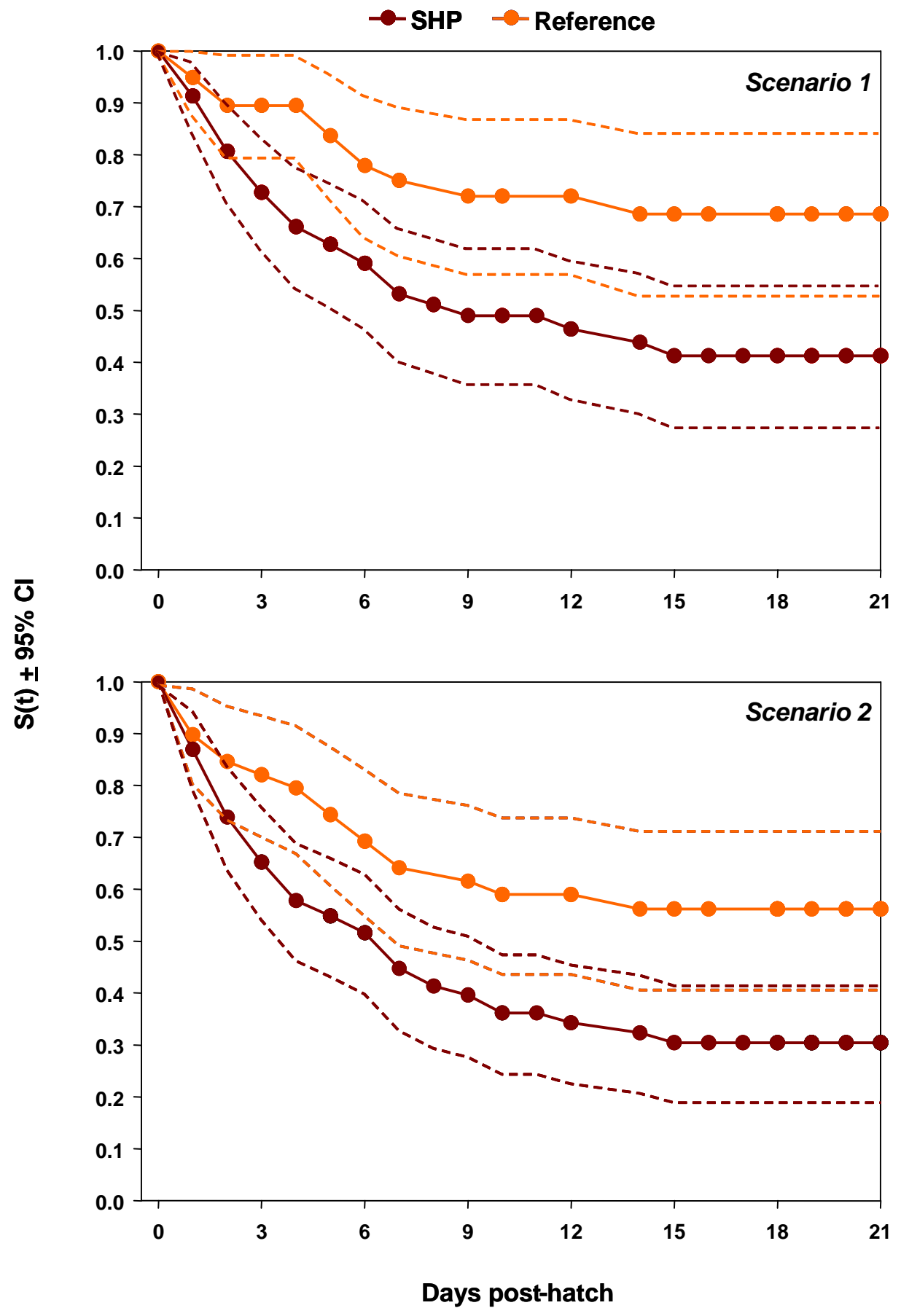

Figure 33. Kaplan Meier survivorship functions ( $\mathrm{S}(\mathrm{t})$, solid lines) and $95 \%$ confidence intervals (dotted lines) to 21 days post-hatch for Black-necked Stilt chicks hatched at the saline habitat ponds (SHP) and reference sites during the 2007-08 breeding seasons, Ecosystem Monitoring Project, Salton Sea, California. Circles represent a mortality or censoring event. See text methods section 4.2.2.2-survival estimation for definitions of scenarios and survival rate estimation. 


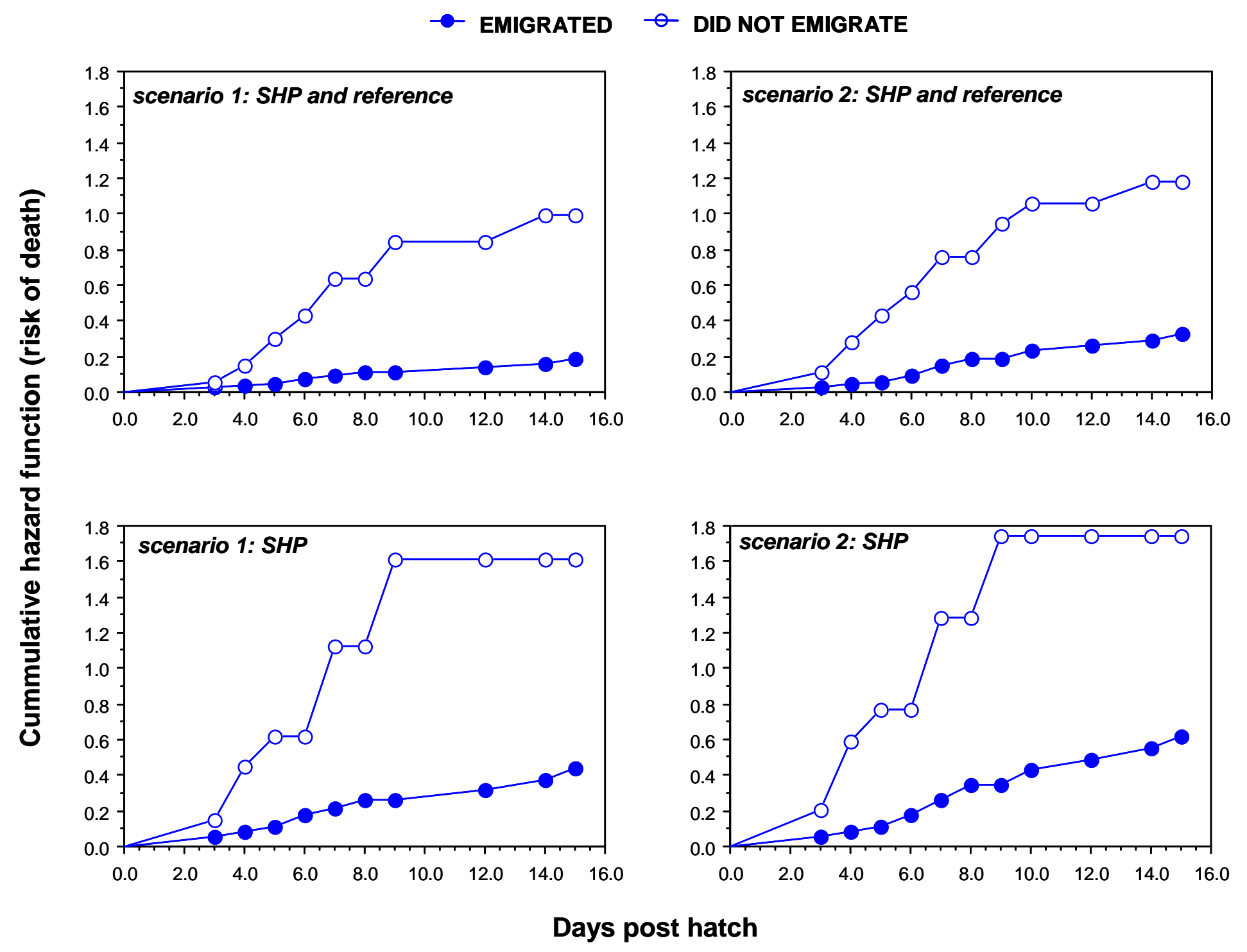

Figure 34. Effect of emigration from hatch site on hazard functions for Black-necked Stilt chicks hatched at the saline habitat ponds (SHP) and reference sites during the 2007-08 breeding seasons, Ecosystem Monitoring Project, Salton Sea, California. Circles represent a mortality or censoring event, only chicks capable of emigrating ( $\geq 3$ days post-hatch) are in included in the analysis; see text methods section 4.2.2.2 - survival estimation for definitions of scenarios and survival rate estimation. 


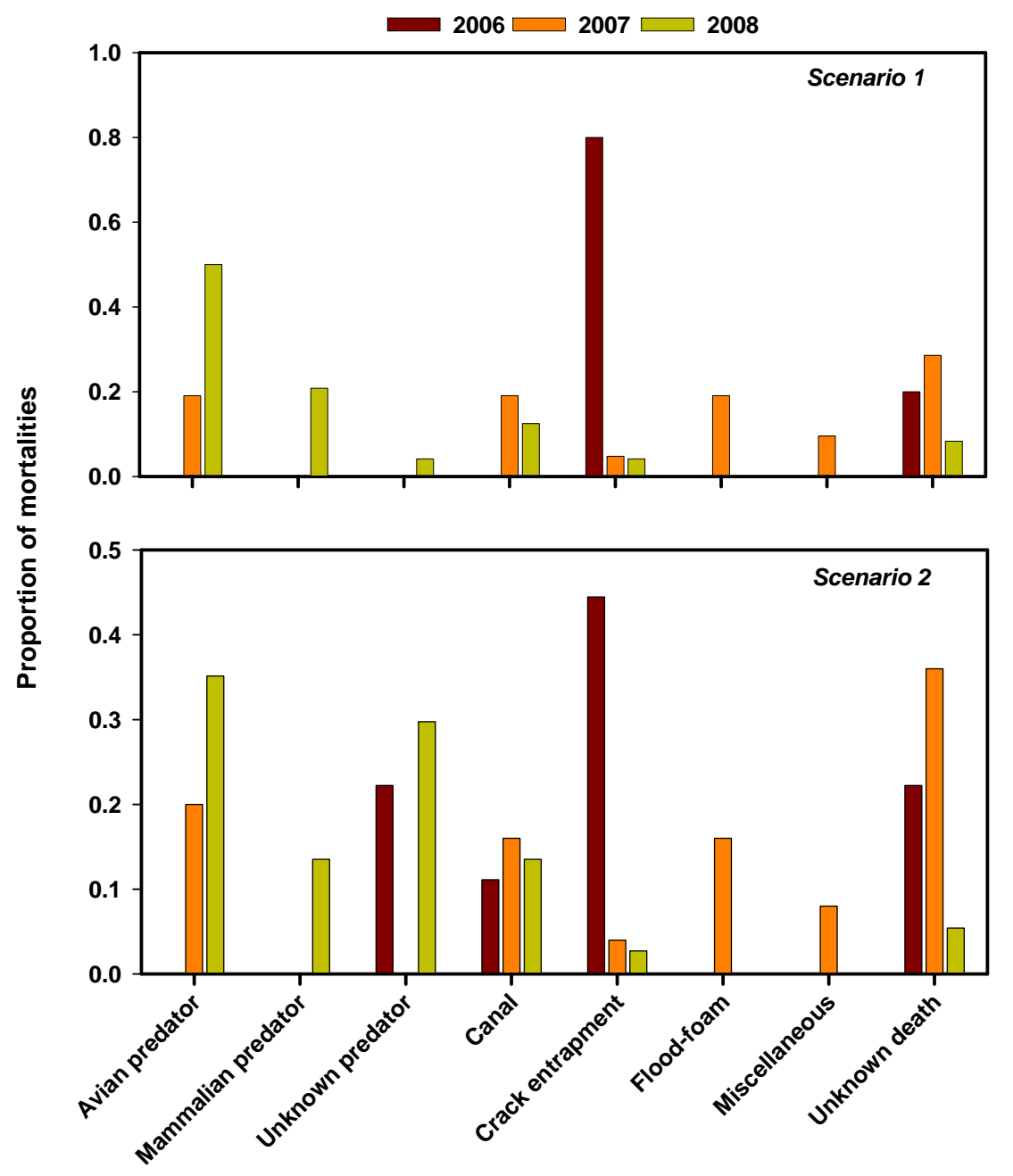

Figure 35. Relative frequencies for probable causes of mortality for all radio-marked post hatch Black-necked Stilt chicks, Ecosystem Monitoring Project, Salton Sea, California, 2006-08. Note $y$ axis varies according to scenario, see text methods section 4.2.2.2 - survival estimation for definitions of scenarios. 
This page left intentionally blank. 


\section{Tables}

Table 1. Geographical coordinates (decimal degrees, NAD83) for fixed water, sediment, and invertebrate sampling points, Ecosystem Monitoring Project, Salton Sea, California, 2006-08.

[SHP, saline habitat ponds. NAD83, North American Datum of 1983]

\begin{tabular}{|c|c|c|c|c|c|}
\hline Group & Site & Water source & Point & $\begin{array}{l}\text { Latitude } \\
\text { (N) }\end{array}$ & $\begin{array}{l}\text { Longitude } \\
\text { (W) }\end{array}$ \\
\hline \multirow[t]{12}{*}{ SHP } & Pond 1 & Salton Sea and Alamo River & P1-1 & 33.206348 & 115.581044 \\
\hline & & & P1-2 & 33.207346 & 115.581629 \\
\hline & & & P1-3 & 33.208249 & 115.581647 \\
\hline & Pond 2 & Pond 1 & P2-1 & 33.212405 & 115.582341 \\
\hline & & & P2-2 & 33.211225 & 115.581641 \\
\hline & & & $\mathrm{P} 2-3$ & 33.21032 & 115.58142 \\
\hline & Pond 3 & Pond 2 & P3-1 & 33.210197 & 115.586443 \\
\hline & & & P3-2 & 33.210997 & 115.58539 \\
\hline & & & P3-3 & 33.211991 & 115.585556 \\
\hline & Pond 4 & Pond 2 & P4-1 & 33.207549 & 115.58361 \\
\hline & & & P4-2 & 33.207479 & 115.585382 \\
\hline & & & P4-3 & 33.208121 & 115.586262 \\
\hline \multirow[t]{16}{*}{ Reference } & Alamo River & Agricultural runoff & AL-1 & 33.199315 & 115.597153 \\
\hline & & & AL-2 & 33.201985 & 115.605167 \\
\hline & & & AL-3 & 33.176778 & 115.575858 \\
\hline & Salton Sea & Salton Sea and Alamo River & SS-1 & 33.20486 & 115.585038 \\
\hline & & & SS- $1 A^{1}$ & 33.204369 & 115.589696 \\
\hline & & & SS-2 & 33.203405 & 115.607987 \\
\hline & & & SS-3 & 33.200669 & 115.597271 \\
\hline & $\begin{array}{l}\text { Freshwater } \\
\text { Marsh }\end{array}$ & Aoricultural runoff & FW-1 & 33217596 & 115586743 \\
\hline & & & FW-2 & 33.223692 & 115.585057 \\
\hline & & & FW-3 & 33.212736 & 115.587647 \\
\hline & D-pond & Colorado River & HQ-1 & 33.183524 & 115.620658 \\
\hline & & & HQ-2 & 33.18074 & 115.617913 \\
\hline & & & HQ-3 & 33.183314 & 115.618345 \\
\hline & Hazard $^{2}$ & Colorado River & HZ-1 & 33.191165 & 115.591855 \\
\hline & & & HZ-2 & 33.187663 & 115.5916 \\
\hline & & & HZ-3 & 33.191141 & 115.593711 \\
\hline
\end{tabular}

${ }^{1}$ SS-1 point moved due to consistent lack of water after fall 2006.

${ }^{2}$ Site added during spring 2008 due to draining of D-Pond in fall 2008. 
Table 2. Arithmetic mean values for water-quality measurements from surface-water samples collected from saline habitat ponds (SHP) and reference sites, Ecosystem Monitoring Project, Salton Sea, California, fall 2006-fall 2008.

[ $\mathrm{n}=3$ for all sites and sampling periods, except for Salton Sea reference samples in fall 2006 where $\mathrm{n}=2 \mathrm{~cm}$, centimeters; $\mathrm{mL} / \mathrm{L}$, milliliters per liter; $\mathrm{mS} / \mathrm{cm}$, millisiemens per centimeter; \%, percent; $\mathrm{mV}$, millivolts;

${ }^{\circ} \mathrm{C}$, degrees Celsius]

\begin{tabular}{|c|c|c|c|c|c|c|c|}
\hline \multirow[b]{2}{*}{ Measurement } & \multirow[b]{2}{*}{ Group } & \multirow[b]{2}{*}{ Site } & \multicolumn{5}{|c|}{ Sampling period } \\
\hline & & & Fall 2006 & Spring 2007 & Fall 2007 & Spring 2008 & Fall 2008 \\
\hline \multirow[t]{8}{*}{ Salinity (mL/L) } & SHP & Pond 1 & 6.5 & 24.1 & 4.2 & 13.0 & 21.2 \\
\hline & & Pond 2 & 16.8 & 29.8 & 9.1 & 29.0 & 24.9 \\
\hline & & Pond 3 & 30.9 & 58.9 & 29.9 & 70.7 & 47.6 \\
\hline & & Pond 4 & $\left({ }^{1}\right)$ & 174.0 & 153.3 & 335.0 & 398.0 \\
\hline & Reference & Salton Sea & 22.9 & 23.6 & 40.0 & 8.4 & 6.2 \\
\hline & & Alamo River & 1.8 & 1.7 & 1.8 & 1.6 & 1.8 \\
\hline & & Freshwater Marsh & 1.6 & 2.1 & 1.3 & 2.6 & 1.3 \\
\hline & & D-pond ${ }^{2}$ & 3.3 & 2.6 & 2.1 & 1.9 & 1.1 \\
\hline \multirow{8}{*}{$\begin{array}{l}\text { Conductivity } \\
(\mathrm{mS} / \mathrm{cm})\end{array}$} & SHP & Pond 1 & 11.8 & 37.9 & 7.6 & 21.8 & 33.7 \\
\hline & & Pond 2 & 27.3 & 45.9 & 15.6 & 35.2 & 39.1 \\
\hline & & Pond 3 & 47.4 & 85.0 & 45.6 & 82.5 & 69.7 \\
\hline & & Pond 4 & $\left({ }^{1}\right)$ & $\left({ }^{1}\right)$ & $\left({ }^{1}\right)$ & $\left({ }^{1}\right)$ & $\left({ }^{1}\right)$ \\
\hline & Reference & Salton Sea & 35.9 & 37.0 & 51.7 & 14.3 & 10.8 \\
\hline & & Alamo River & 3.3 & 3.2 & 3.3 & 3.0 & 3.3 \\
\hline & & Freshwater Marsh & 3.0 & 3.8 & 2.4 & 4.4 & 2.4 \\
\hline & & D-pond & 6.0 & 4.7 & 3.8 & 3.5 & 2.1 \\
\hline \multirow[t]{8}{*}{$\mathrm{pH}$ (units) } & SHP & Pond 1 & 8.32 & 7.52 & 7.91 & 7.53 & 8.32 \\
\hline & & Pond 2 & 8.38 & 7.79 & 8.23 & 7.43 & 8.61 \\
\hline & & Pond 3 & 8.96 & 8.39 & 8.37 & 7.99 & 8.85 \\
\hline & & Pond 4 & 8.1 & 7.57 & 7.82 & 7.45 & 7.71 \\
\hline & Reference & Salton Sea & 8.48 & 8.43 & 8.71 & 8.25 & 8.55 \\
\hline & & Alamo River & 7.87 & 7.83 & 7.66 & 7.21 & 7.61 \\
\hline & & Freshwater Marsh & 8.27 & 8.07 & 8.22 & 7.33 & 7.14 \\
\hline & & D-pond & 8.66 & 8.6 & 8.53 & 7.5 & 7.02 \\
\hline \multirow[t]{8}{*}{ Depth (cm) } & SHP & Pond 1 & 37.7 & 38.7 & 32.0 & 28.3 & 34.3 \\
\hline & & Pond 2 & 23.0 & 20.0 & 12.3 & 15.7 & 22.7 \\
\hline & & Pond 3 & 21.3 & 35.0 & 22.0 & 23.3 & 21.7 \\
\hline & & Pond 4 & 29.0 & 11.3 & 15.0 & 15.0 & 20.7 \\
\hline & Reference & Salton Sea & 13.5 & 29 & 6.67 & 9.67 & 14.33 \\
\hline & & Alamo River & 70.0 & 39.7 & 35.0 & 26.0 & 21.7 \\
\hline & & Freshwater Marsh & 9.7 & 12.0 & 23.3 & 20.0 & 25.3 \\
\hline & & D-pond & 24.7 & 21.3 & 27.3 & 20.7 & 25.3 \\
\hline
\end{tabular}


Table 2. Arithmetic mean values for water-quality measurements from surface-water samples collected from saline habitat ponds (SHP) and reference sites, Ecosystem Monitoring Project, Salton Sea, California, fall 2006-fall 2008.-Continued.

[ $\mathrm{n}=3$ for all sites and sampling periods, except for Salton Sea reference samples in fall 2006 where $\mathrm{n}=2 \mathrm{~cm}$, centimeters; $\mathrm{mL} / \mathrm{L}$, milliliters per liter; $\mathrm{mS} / \mathrm{cm}$, millisiemens per centimeter; \%, percent; $\mathrm{mV}$, millivolts;

${ }^{\circ} \mathrm{C}$, degrees Celsius]

\begin{tabular}{|c|c|c|c|c|c|c|c|}
\hline \multirow[b]{2}{*}{ Measurement } & \multirow[b]{2}{*}{ Group } & \multirow[b]{2}{*}{ Site } & \multicolumn{5}{|c|}{ Sampling period } \\
\hline & & & $\begin{array}{c}\text { Fall } \\
2006 \\
\end{array}$ & $\begin{array}{c}\text { Spring } \\
2007\end{array}$ & $\begin{array}{l}\text { Fall } \\
2007\end{array}$ & $\begin{array}{c}\text { Spring } \\
2008\end{array}$ & $\begin{array}{l}\text { Fall } \\
2008\end{array}$ \\
\hline \multirow[t]{8}{*}{ DO (\%) } & \multirow[t]{4}{*}{ SHP } & Pond 1 & 76.0 & 44.1 & 92.7 & 88.1 & 107.6 \\
\hline & & Pond 2 & 60.3 & 91.9 & 105.5 & 93.2 & 166.5 \\
\hline & & Pond 3 & 139.1 & 124.3 & 76.4 & 119.5 & 71.6 \\
\hline & & Pond 4 & 135.4 & 140.6 & 222.7 & 372.0 & 98.4 \\
\hline & \multirow[t]{4}{*}{ Reference } & Salton Sea & 75.1 & 127.3 & 119.0 & 199.8 & 149.4 \\
\hline & & Alamo River & 79.7 & 48.0 & 84.8 & 84.5 & 92.6 \\
\hline & & Freshwater Marsh & 115.9 & 108.7 & 162.4 & 157.5 & 78.4 \\
\hline & & D-pond & 58.3 & 95.1 & 76.7 & 89.2 & 52.8 \\
\hline \multirow[t]{8}{*}{ ORP (mV) } & \multirow[t]{4}{*}{ SHP } & Pond 1 & 281 & 490 & 424 & 282 & 374 \\
\hline & & Pond 2 & 368 & 472 & 313 & 361 & 370 \\
\hline & & Pond 3 & 293 & 418 & 260 & 264 & 284 \\
\hline & & Pond 4 & 167 & 465 & 343 & 328 & 321 \\
\hline & \multirow[t]{4}{*}{ Reference } & Salton Sea & 19 & 178 & 347 & 223 & 346 \\
\hline & & Alamo River & 273 & 334 & 530 & 309 & 385 \\
\hline & & Freshwater Marsh & 271 & 372 & 274 & 475 & 500 \\
\hline & & D-pond & 280 & 267 & 422 & 457 & 481 \\
\hline \multirow{8}{*}{$\begin{array}{l}\text { Temperature } \\
\left({ }^{\circ} \mathrm{C}\right)\end{array}$} & \multirow[t]{4}{*}{ SHP } & Pond 1 & 21.6 & 20.1 & 23.6 & 20.8 & 25.2 \\
\hline & & Pond 2 & 19.4 & 21.8 & 24.8 & 14.8 & 25.3 \\
\hline & & Pond 3 & 23.0 & 24.3 & 17.8 & 18.9 & 19.3 \\
\hline & & Pond 4 & 20.5 & 26.4 & 22.5 & 24.8 & 24.0 \\
\hline & \multirow[t]{4}{*}{ Reference } & Salton Sea & 27.5 & 32.2 & 20.9 & 30.8 & 28.6 \\
\hline & & Alamo River & 22.6 & 22.2 & 20.9 & 20.9 & 21.5 \\
\hline & & Freshwater Marsh & 27.1 & 22.5 & 25.0 & 21.9 & 18.8 \\
\hline & & D-pond & 21.1 & 27.9 & 19.0 & 19.4 & 17.0 \\
\hline
\end{tabular}

${ }^{1}$ Value exceeded measuring device capacity (salinity $=70 \mathrm{~mL} / \mathrm{L}$, conductivity $=100 \mathrm{mS} / \mathrm{cm}$ ).

${ }^{2}$ D-pond was dry in fall 2008, thus Salton Sea National Wildlife Refuge Hazard Pond sampled in its place. 
Table 3. Arithmetic mean values for water nutrient measurements from surface water samples collected from saline habitat ponds (SHP) and reference sites, Ecosystem Monitoring Project, Salton Sea, California, fall 2006-fall 2008.

[ $\mathrm{n}=3$ for all sites and sampling periods, except for all fall 2006 sites where $\mathrm{n}=2$. ND, all concentrations below limit of detection (nitrate $=0.05-0.10 \mathrm{mg} / \mathrm{L}$, phosphorous $=0.2-2.0 \mathrm{mg} / \mathrm{L}$; varied according to salinity). NQ, analyte not quantified. $\mathrm{mg} / \mathrm{L}$, milligrams per liter]

\begin{tabular}{|c|c|c|c|c|c|c|c|}
\hline \multirow[b]{2}{*}{ Analyte } & \multirow[b]{2}{*}{ Group } & \multirow[b]{2}{*}{ Site } & \multicolumn{5}{|c|}{ Sampling period } \\
\hline & & & $\begin{array}{l}\text { Fall } \\
2006\end{array}$ & $\begin{array}{c}\text { Spring } \\
2007\end{array}$ & $\begin{array}{l}\text { Fall } \\
2007\end{array}$ & $\begin{array}{c}\text { Spring } \\
2008\end{array}$ & $\begin{array}{l}\text { Fall } \\
2008\end{array}$ \\
\hline \multirow{8}{*}{$\begin{array}{l}\text { Ammonium } \\
\text { (mg/L) }\end{array}$} & \multirow[t]{4}{*}{ SHP } & Pond 1 & 0.40 & 0.89 & 0.21 & 0.44 & 1.16 \\
\hline & & Pond 2 & 0.26 & 0.24 & 0.19 & 0.30 & 0.15 \\
\hline & & Pond 3 & 0.60 & 0.09 & 0.27 & 0.42 & 0.25 \\
\hline & & Pond 4 & 6.23 & 1.58 & 0.57 & 0.55 & 0.51 \\
\hline & \multirow[t]{4}{*}{ Reference } & Alamo River & 0.45 & 0.86 & 0.33 & 1.56 & 0.26 \\
\hline & & Salton Sea & 14.63 & 0.70 & 2.19 & 1.59 & 0.93 \\
\hline & & Freshwater Marsh & 0.19 & 0.34 & 0.05 & 0.04 & 0.14 \\
\hline & & D-pond ${ }^{1}$ & 0.24 & 0.85 & 0.13 & 0.87 & 0.12 \\
\hline \multirow[t]{8}{*}{$\begin{array}{l}\text { Nitrate } \\
\text { (mg/L) }\end{array}$} & \multirow[t]{4}{*}{ SHP } & Pond 1 & 0.98 & 0.05 & 0.31 & 0.48 & 0.10 \\
\hline & & Pond 2 & ND & 0.04 & 0.11 & 0.19 & ND \\
\hline & & Pond 3 & ND & ND & ND & 0.18 & ND \\
\hline & & Pond 4 & 0.03 & ND & ND & 0.28 & ND \\
\hline & \multirow[t]{4}{*}{ Reference } & Alamo River & 5.87 & 6.88 & 6.14 & 4.20 & 6.45 \\
\hline & & Salton Sea & 0.07 & 0.08 & ND & 0.30 & 0.57 \\
\hline & & Freshwater Marsh & 0.16 & 3.55 & 0.17 & 0.39 & 0.37 \\
\hline & & D-pond & ND & 0.04 & ND & 0.07 & ND \\
\hline \multirow{8}{*}{$\begin{array}{l}\text { Phosphorous } \\
(\mathrm{mg} / \mathrm{L})^{2}\end{array}$} & \multirow[t]{4}{*}{ SHP } & Pond 1 & 0.13 & 0.13 & ND & 0.07 & 0.23 \\
\hline & & Pond 2 & 0.17 & 0.20 & ND & ND & 0.12 \\
\hline & & Pond 3 & 0.43 & 0.20 & ND & 0.13 & 0.20 \\
\hline & & Pond 4 & 1.33 & 2.40 & ND & 3.20 & 2.07 \\
\hline & \multirow[t]{4}{*}{ Reference } & Alamo River & 0.50 & 0.40 & 0.50 & 0.43 & 0.27 \\
\hline & & Salton Sea & 1.03 & 0.23 & 0.83 & 0.07 & 0.33 \\
\hline & & Freshwater Marsh & 0.08 & 0.35 & ND & 0.15 & 0.07 \\
\hline & & D-pond & 0.10 & ND & ND & ND & ND \\
\hline \multirow{8}{*}{$\begin{array}{l}\text { Total } \\
\text { dissolved } \\
\text { solids } \\
(\mathrm{mg} / \mathrm{L})\end{array}$} & \multirow[t]{4}{*}{ SHP } & Pond 1 & NQ & 23,757 & 3,040 & 12,477 & 23,410 \\
\hline & & Pond 2 & NQ & 28,837 & 10,757 & 23,937 & 28,673 \\
\hline & & Pond 3 & NQ & 58,587 & 33,300 & 63,133 & 54,843 \\
\hline & & Pond 4 & NQ & 181,223 & 170,730 & 304,007 & 266,970 \\
\hline & \multirow[t]{4}{*}{ Reference } & Alamo River & NQ & 1,953 & 2,147 & 1,817 & 2,253 \\
\hline & & Salton Sea & NQ & 24,007 & 45,147 & 8,900 & 7,167 \\
\hline & & Freshwater Marsh & NQ & 2,000 & 1,640 & 2,307 & 1,513 \\
\hline & & D-pond & NQ & 2,460 & 2,343 & 2,143 & 1,293 \\
\hline
\end{tabular}

${ }^{1}$ D-pond was dry in fall 2008, thus Salton Sea National Wildlife Refuge Hazard Pond sampled in its place. ${ }^{2}$ Quantified as total P in unfiltered sample in fall 2006, quantified as soluble P by ICP in all other sampling periods. 
Table 4. Arithmetic mean values for sediment salinity measurements from sediment samples collected from saline habitat ponds (SHP) and reference sites, Ecosystem Monitoring Project, Salton Sea, California, spring 2006-fall 2008.

[ $\mathrm{n}=3$ for all sites and sampling periods, except for spring 2006 Freshwater Marsh $(\mathrm{n}=2)$, Alamo River $(\mathrm{n}=1)$ and D-pond $(n=1)$. ND, all concentrations below limit of detection. meq/L, milliequivalents per liter; $\mathrm{dS} / \mathrm{m}$, deciSiemens per meter]

\begin{tabular}{|c|c|c|c|c|c|c|c|c|}
\hline \multirow[b]{2}{*}{ Analyte } & \multirow[b]{2}{*}{ Group } & \multirow[b]{2}{*}{ Site } & \multicolumn{6}{|c|}{ Sampling period } \\
\hline & & & $\begin{array}{c}\text { Spring } \\
2006\end{array}$ & $\begin{array}{c}\text { Fall } \\
2006\end{array}$ & $\begin{array}{c}\text { Spring } \\
2007\end{array}$ & $\begin{array}{c}\text { Fall } \\
2007\end{array}$ & $\begin{array}{c}\text { Spring } \\
2008\end{array}$ & Fall 2008 \\
\hline \multirow[t]{8}{*}{$\mathrm{pH}$} & SHP & Pond 1 & 7.8 & 8.0 & 8.0 & 7.9 & 7.9 & 8.0 \\
\hline & & Pond 2 & 7.4 & 8.1 & 8.1 & 8.1 & 8.1 & 8.1 \\
\hline & & Pond 3 & 7.8 & 8.0 & 8.1 & 8.2 & 8.1 & 8.1 \\
\hline & & Pond 4 & 8.1 & 8.2 & 8.2 & 7.9 & 7.7 & 7.3 \\
\hline & Reference & Alamo River & 7.9 & 7.9 & 8.1 & 8.0 & 8.0 & 7.8 \\
\hline & & Salton Sea & 8.2 & 8.3 & 8.3 & 8.1 & 8.0 & 7.9 \\
\hline & & Freshwater Marsh & 7.8 & 7.8 & 8.0 & 7.8 & 7.5 & 7.5 \\
\hline & & D-pond ${ }^{1}$ & 8.1 & 8.0 & 8.0 & 8.0 & 7.9 & 7.9 \\
\hline \multirow{8}{*}{$\begin{array}{l}\text { Carbonate } \\
\left(\mathrm{CO}_{3} \text {, }\right. \\
\mathrm{meq} / \mathrm{L})\end{array}$} & SHP & Pond 1 & 0.5 & ND & ND & ND & ND & ND \\
\hline & & Pond 2 & 0.6 & ND & ND & ND & ND & ND \\
\hline & & Pond 3 & 0.1 & ND & $\mathrm{ND}$ & 0.1 & 0.2 & 0.4 \\
\hline & & Pond 4 & ND & 0.3 & 0.4 & 0.7 & ND & 2.7 \\
\hline & Reference & Alamo River & ND & ND & ND & ND & 0.4 & ND \\
\hline & & Salton Sea & 0.4 & 0.4 & ND & ND & 0.2 & ND \\
\hline & & Freshwater Marsh & ND & ND & $\mathrm{ND}$ & ND & $\mathrm{ND}$ & ND \\
\hline & & D-pond & ND & ND & $\mathrm{ND}$ & ND & ND & ND \\
\hline \multirow{8}{*}{$\begin{array}{l}\text { Bicarbonate } \\
\left(\mathrm{HCO}_{3},\right. \\
\mathrm{meq} / \mathrm{L})\end{array}$} & SHP & Pond 1 & 1.8 & 3.5 & 2.6 & 5.9 & 4.4 & 2.8 \\
\hline & & Pond 2 & 1.5 & 2.7 & 2.1 & 4.2 & 4.2 & 2.6 \\
\hline & & Pond 3 & 1.7 & 4.5 & 1.8 & 3.8 & 3.7 & 3.5 \\
\hline & & Pond 4 & 1.7 & 4.4 & 1.9 & 4.4 & 4.7 & 2.0 \\
\hline & Reference & Alamo River & 3.0 & 4.0 & 2.5 & 3.9 & 4.8 & 2.7 \\
\hline & & Salton Sea & 4.5 & 5.6 & 3.6 & 5.5 & 4.9 & 4.0 \\
\hline & & Freshwater Marsh & 2.5 & 4.6 & 3.0 & 5.5 & 5.5 & 3.5 \\
\hline & & D-pond & 2.3 & 3.6 & 3.0 & 4.5 & 5.5 & 2.4 \\
\hline \multirow{8}{*}{$\begin{array}{l}\text { Estimated } \\
\text { soluble salts } \\
\text { (EC, dS/m) }\end{array}$} & SHP & Pond 1 & 262.2 & 19.5 & 34.5 & 12.2 & 28.1 & 39.7 \\
\hline & & Pond 2 & 390.8 & 49.2 & 41.9 & 28.8 & 41.7 & 46.9 \\
\hline & & Pond 3 & 182.9 & 58.7 & 76.2 & 94.5 & 109.7 & 101.7 \\
\hline & & Pond 4 & 165.7 & 105.5 & 156.9 & 274.3 & 320.9 & 442.4 \\
\hline & Reference & Alamo River & 6.9 & 4.1 & 5.2 & 4.4 & 6.2 & 5.5 \\
\hline & & Salton Sea & 57.2 & 149.4 & 39.0 & 80.3 & 38.0 & 22.9 \\
\hline & & Freshwater Marsh & 11.0 & 7.7 & 7.6 & 6.7 & 8.8 & 10.6 \\
\hline & & D-pond & 29.8 & 9.9 & 7.0 & 8.8 & 6.5 & 9.9 \\
\hline
\end{tabular}


Table 4. Arithmetic mean values for sediment salinity measurements from sediment samples collected from saline habitat ponds (SHP) and reference sites, Ecosystem Monitoring Project, Salton Sea, California, spring 2006-fall 2008.-Continued

[ $\mathrm{n}=3$ for all sites and sampling periods, except for spring 2006 Freshwater Marsh $(\mathrm{n}=2)$, Alamo River $(\mathrm{n}=1)$ and D-pond $(n=1)$. ND, all concentrations below limit of detection. meq/L, milliequivalents per liter; $\mathrm{dS} / \mathrm{m}$, deciSiemens per meter]

\begin{tabular}{|c|c|c|c|c|c|c|c|c|}
\hline \multirow[b]{2}{*}{ Analyte } & \multirow[b]{2}{*}{ Group } & \multirow[b]{2}{*}{ Site } & \multicolumn{6}{|c|}{ Sampling period } \\
\hline & & & $\begin{array}{c}\text { Spring } \\
2006\end{array}$ & $\begin{array}{l}\text { Fall } \\
2006\end{array}$ & $\begin{array}{l}\text { Spring } \\
2007\end{array}$ & $\begin{array}{l}\text { Fall } \\
2007\end{array}$ & $\begin{array}{c}\text { Spring } \\
2008\end{array}$ & $\begin{array}{l}\text { Fall } \\
2008\end{array}$ \\
\hline \multirow{8}{*}{$\begin{array}{l}\text { Calcium } \\
\text { (Ca, meq/L) }\end{array}$} & \multirow[t]{4}{*}{ SHP } & Pond 1 & 93.9 & 37.0 & 39.0 & 27.2 & 36.7 & 44.0 \\
\hline & & Pond 2 & 152.4 & 49.7 & 44.3 & 36.9 & 39.8 & 42.0 \\
\hline & & Pond 3 & 109.8 & 49.5 & 54.1 & 41.2 & 44.1 & 42.0 \\
\hline & & Pond 4 & 61.6 & 61.2 & 59.8 & 23.0 & 24.5 & 16.2 \\
\hline & \multirow[t]{4}{*}{ Reference } & Alamo River & 20.1 & 13.4 & 13.7 & 14.2 & 19.1 & 18.4 \\
\hline & & Salton Sea & 39.2 & 39.0 & 37.2 & 32.2 & 30.2 & 29.3 \\
\hline & & Freshwater Marsh & 28.3 & 22.3 & 19.3 & 20.4 & 24.7 & 25.8 \\
\hline & & D-pond & 37.1 & 20.3 & 15.8 & 16.6 & 12.8 & 26.5 \\
\hline \multirow{8}{*}{$\begin{array}{l}\text { Chloride } \\
\text { (Cl, meq/L) }\end{array}$} & \multirow[t]{4}{*}{ SHP } & Pond 1 & $2,094.2$ & 128.1 & 280.6 & 68.1 & 214.5 & 342.3 \\
\hline & & Pond 2 & $3,346.5$ & 358.6 & 346.5 & 234.1 & 324.6 & 408.8 \\
\hline & & Pond 3 & $1,557.6$ & 440.9 & $1,318.7$ & 848.5 & 996.4 & 927.6 \\
\hline & & Pond 4 & $1,306.4$ & 869.7 & 2,934.0 & $2,739.0$ & $3,018.4$ & $4,554.5$ \\
\hline & \multirow[t]{4}{*}{ Reference } & Alamo River & 27.6 & 16.2 & 30.6 & 21.0 & 29.8 & 27.2 \\
\hline & & Salton Sea & 836.3 & $1,135.6$ & 330.9 & 756.1 & 298.3 & 161.7 \\
\hline & & Freshwater Marsh & 57.9 & 27.9 & 37.5 & 30.7 & 41.9 & 57.3 \\
\hline & & D-pond & 214.6 & 100.8 & 36.7 & 52.8 & 33.9 & 69.1 \\
\hline \multirow{8}{*}{$\begin{array}{l}\text { Magnesium } \\
\text { (Mg, meq/L) }\end{array}$} & \multirow[t]{4}{*}{ SHP } & Pond 1 & 536.3 & 44.9 & 53.8 & 34.1 & 53.6 & 75.9 \\
\hline & & Pond 2 & 800.6 & 90.1 & 62.3 & 60.0 & 71.3 & 77.7 \\
\hline & & Pond 3 & 356.0 & 101.9 & 117.2 & 161.8 & 187.2 & 170.1 \\
\hline & & Pond 4 & 304.3 & 224.0 & 256.6 & 510.2 & 547.0 & 857.3 \\
\hline & \multirow[t]{4}{*}{ Reference } & Alamo River & 15.7 & 10.4 & 12.3 & 11.9 & 19.8 & 14.7 \\
\hline & & Salton Sea & 175.1 & 232.8 & 70.2 & 141.5 & 67.8 & 53.5 \\
\hline & & Freshwater Marsh & 34.2 & 27.5 & 21.0 & 24.5 & 31.4 & 35.1 \\
\hline & & D-pond & 74.5 & 34.6 & 18.9 & 25.8 & 17.8 & 26.3 \\
\hline \multirow{8}{*}{$\begin{array}{l}\text { Sodium } \\
\text { (Na, meq/L) }\end{array}$} & \multirow{4}{*}{ SHP } & Pond 1 & $1,899.6$ & 146.2 & 296.0 & 124.9 & 225.1 & 301.0 \\
\hline & & Pond 2 & $2,826.0$ & 372.8 & 342.1 & 249.9 & 328.7 & 380.0 \\
\hline & & Pond 3 & $1,353.8$ & 452.2 & 611.5 & 898.9 & $1,019.2$ & 894.6 \\
\hline & & Pond 4 & $1,328.2$ & 800.3 & $1,325.3$ & $2,837.4$ & $3,153.0$ & $3,914.3$ \\
\hline & \multirow[t]{4}{*}{ Reference } & Alamo River & 36.6 & 21.1 & 30.6 & 22.9 & 35.3 & 29.2 \\
\hline & & Salton Sea & 964.7 & $1,311.9$ & 370.1 & 781.8 & 321.2 & 181.9 \\
\hline & & Freshwater Marsh & 70.5 & 39.7 & 44.4 & 38.1 & 51.6 & 60.3 \\
\hline & & D-pond & 250.0 & 58.3 & 44.7 & 62.0 & 42.0 & 58.8 \\
\hline
\end{tabular}

\footnotetext{
${ }^{1}$ D-pond was dry in fall 2008, Salton Sea National Wildlife Refuge Hazard Pond sampled in its place.
} 
Table 5. Arithmetic mean values for sediment composition measurements from sediment samples collected from saline habitat ponds (SHP) and reference sites, Ecosystem Monitoring Project, Salton Sea, California, spring 2006-fall 2008.

[ $\mathrm{n}=3$ for all sites and sampling periods, except for spring 2006 Freshwater Marsh $(\mathrm{n}=2)$, Alamo River $(\mathrm{n}=1)$ and D-pond $(\mathrm{n}=1)$. NQ, analyte not quantified. \%, percent]

\begin{tabular}{|c|c|c|c|c|c|c|c|c|}
\hline \multirow[b]{2}{*}{ Analyte } & \multirow[b]{2}{*}{ Group } & \multirow[b]{2}{*}{ Site } & \multicolumn{6}{|c|}{ Sampling period } \\
\hline & & & $\begin{array}{c}\text { Spring } \\
2006 \\
\end{array}$ & Fall 2006 & $\begin{array}{c}\text { Spring } \\
2007 \\
\end{array}$ & Fall 2007 & $\begin{array}{c}\text { Spring } \\
2008 \\
\end{array}$ & $\begin{array}{l}\text { Fall } \\
2008 \\
\end{array}$ \\
\hline \multirow{8}{*}{$\begin{array}{l}\text { Organic } \\
\text { carbon (\%) }\end{array}$} & \multirow[t]{4}{*}{ SHP } & Pond 1 & 1.0 & 1.2 & 1.2 & 1.2 & 0.9 & 0.9 \\
\hline & & Pond 2 & 0.7 & 0.4 & 0.5 & 0.6 & 0.5 & 0.7 \\
\hline & & Pond 3 & 1.8 & 2.0 & 2.0 & 1.7 & 1.7 & 1.6 \\
\hline & & Pond 4 & 1.8 & 1.3 & 1.5 & 1.5 & 1.5 & 1.4 \\
\hline & \multirow[t]{4}{*}{ Reference } & Alamo River & 0.6 & 0.5 & 0.5 & 0.5 & 0.4 & 0.5 \\
\hline & & Salton Sea & 1.7 & 1.5 & 1.9 & 1.2 & 1.6 & 1.2 \\
\hline & & Freshwater Marsh & 1.5 & 1.6 & 1.5 & 1.6 & 1.6 & 1.7 \\
\hline & & D-pond ${ }^{1}$ & 0.3 & 1.0 & 0.6 & 0.8 & 1.0 & 0.6 \\
\hline \multirow{8}{*}{$\begin{array}{l}\text { Organic } \\
\text { matter (\%) }\end{array}$} & \multirow[t]{4}{*}{ SHP } & Pond 1 & 1.8 & 2.1 & 2.0 & 2.0 & 1.5 & 1.5 \\
\hline & & Pond 2 & 1.2 & 0.8 & 0.9 & 1.1 & 0.9 & 1.2 \\
\hline & & Pond 3 & 3.0 & 3.5 & 3.4 & 2.9 & 2.9 & 2.8 \\
\hline & & Pond 4 & 3.1 & 2.3 & 2.6 & 2.7 & 2.6 & 2.3 \\
\hline & \multirow[t]{4}{*}{ Reference } & Alamo River & 1.0 & 0.9 & 0.9 & 0.8 & 0.7 & 0.9 \\
\hline & & Salton Sea & 2.9 & 2.6 & 3.2 & 2.1 & 2.8 & 2.0 \\
\hline & & Freshwater Marsh & 2.5 & 2.7 & 2.5 & 2.7 & 2.8 & 3.0 \\
\hline & & D-pond & 0.5 & 1.6 & 1.1 & 1.5 & 1.6 & 1.1 \\
\hline \multirow[t]{8}{*}{ Sand (\%) } & \multirow[t]{4}{*}{ SHP } & Pond 1 & 27.3 & 12.7 & 22.3 & 20.0 & NQ & 33.3 \\
\hline & & Pond 2 & 42.3 & 40.7 & 39.0 & 38.7 & NQ & 32.7 \\
\hline & & Pond 3 & 18.0 & 11.0 & 12.3 & 22.3 & NQ & 25.7 \\
\hline & & Pond 4 & 13.0 & 16.3 & 17.0 & 23.7 & NQ & 19.3 \\
\hline & \multirow[t]{4}{*}{ Reference } & Alamo River & 48.0 & 32.7 & 36.7 & 25.3 & NQ & 47.7 \\
\hline & & Salton Sea & 25.7 & 20.0 & 22.7 & 32.7 & NQ & 43.3 \\
\hline & & Freshwater Marsh & 11.5 & 18.3 & 23.7 & 24.3 & NQ & 22.7 \\
\hline & & D-pond & 70.0 & 11.3 & 37.7 & 21.7 & NQ & 9.3 \\
\hline \multirow[t]{8}{*}{ Silt (\%) } & \multirow[t]{4}{*}{ SHP } & Pond 1 & 51.0 & 46.7 & 40.0 & 40.7 & NQ & 32.3 \\
\hline & & Pond 2 & 44.7 & 53.7 & 38.7 & 45.0 & NQ & 53.0 \\
\hline & & Pond 3 & 61.7 & 54.7 & 53.3 & 64.0 & NQ & 57.0 \\
\hline & & Pond 4 & 51.0 & 51.3 & 62.3 & 58.3 & NQ & 47.3 \\
\hline & \multirow[t]{4}{*}{ Reference } & Alamo River & 30.0 & 41.0 & 36.7 & 47.7 & NQ & 30.7 \\
\hline & & Salton Sea & 40.3 & 50.3 & 40.7 & 35.7 & NQ & 30.7 \\
\hline & & Freshwater Marsh & 50.0 & 50.7 & 45.0 & 44.7 & NQ & 42.3 \\
\hline & & D-pond & 19.0 & 58.7 & 39.7 & 51.0 & NQ & 43.0 \\
\hline \multirow[t]{8}{*}{ Clay (\%) } & \multirow[t]{4}{*}{ SHP } & Pond 1 & 21.7 & 40.7 & 37.7 & 39.3 & NQ & 34.3 \\
\hline & & Pond 2 & 13.0 & 5.7 & 22.3 & 16.3 & NQ & 14.3 \\
\hline & & Pond 3 & 20.3 & 34.3 & 34.3 & 13.7 & NQ & 17.3 \\
\hline & & Pond 4 & 36.0 & 32.3 & 20.7 & 18.0 & NQ & 33.3 \\
\hline & \multirow[t]{4}{*}{ Reference } & Alamo River & 22.0 & 26.3 & 26.7 & 27.0 & NQ & 21.7 \\
\hline & & Salton Sea & 34.0 & 29.7 & 36.7 & 31.7 & NQ & 26.0 \\
\hline & & Freshwater Marsh & 38.5 & 31.0 & 31.3 & 31.0 & NQ & 35.0 \\
\hline & & D-pond & 11.0 & 30.0 & 22.7 & 27.3 & NQ & 47.7 \\
\hline
\end{tabular}

${ }^{1}$ D-pond was dry in fall 2008, thus Salton Sea National Wildlife Refuge Hazard Pond sampled in its place. 
Table 6. Percent relative abundance of macroinvertebrates collected from saline habitat ponds (SHP) and references sites, Ecosystem Monitoring Project, Salton Sea, California, fall 2006-fall 2008.

[Totals represent 9 Ekman benthic grab and 3 D-ring sweep samples at each site, enumerated to the nearest taxonomic class, order, and/or family. Relative abundance for taxa with less than 10 individuals at any sampling period and site are not listed. Pond 4, hypersaline intolerant taxa (that is, non-Ephydridae) encountered in Pond 4 after fall 2006 typically were dead at time of collection. Wind and/or water flow through the SHP was the probable reason for their occurrence in Pond 4. --, sites with no invertebrates]

\begin{tabular}{|c|c|c|c|c|c|c|c|c|c|c|}
\hline \multirow[b]{3}{*}{ Class } & \multirow[b]{3}{*}{ Order } & \multirow[b]{3}{*}{ Family } & \multicolumn{8}{|c|}{ Fall 2006} \\
\hline & & & \multicolumn{4}{|c|}{ SHP } & \multicolumn{4}{|c|}{ Reference } \\
\hline & & & Pond 1 & Pond 2 & Pond 3 & Pond $4^{2}$ & $\begin{array}{l}\text { Alamo } \\
\text { River }\end{array}$ & $\begin{array}{c}\text { Salton } \\
\text { Sea }\end{array}$ & $\begin{array}{c}\text { Freshwater } \\
\text { Marsh }\end{array}$ & D-pond \\
\hline \multirow[t]{2}{*}{ Polychaeta } & Capitellida & Capitellidae & 1.3 & 3.6 & -- & -- & 7.0 & 57.0 & -- & -- \\
\hline & Aciculata & Nereidae & 0.4 & 0.0 & -- & -- & 5.0 & -- & -- & -- \\
\hline \multirow[t]{11}{*}{ Insecta } & Ephemeroptera & Baetidae & -- & -- & -- & -- & -- & -- & -- & -- \\
\hline & Diptera & Ceratopogonidae & -- & -- & -- & -- & -- & -- & -- & -- \\
\hline & & Chironomidae & 47.3 & 31.5 & -- & -- & 7.0 & -- & 41.4 & 85.6 \\
\hline & & Ephydridae & -- & -- & 0.1 & 0.5 & -- & -- & -- & -- \\
\hline & & Other Diptera & 0.4 & -- & -- & 0.1 & -- & 10.0 & 0.0 & 1.9 \\
\hline & Hemiptera & Corixidae & -- & 63.9 & 99.9 & 99.3 & 10.0 & 6.2 & 56.0 & 7.4 \\
\hline & & Notonectidae & -- & -- & -- & -- & -- & -- & -- & -- \\
\hline & & Aphididae & -- & -- & -- & -- & -- & -- & -- & -- \\
\hline & & Other Hemiptera & -- & -- & -- & -- & -- & -- & -- & -- \\
\hline & Coleoptera & Dytiscidae & -- & -- & -- & -- & -- & -- & -- & -- \\
\hline & & Hydrophilidae & -- & -- & -- & -- & -- & -- & -- & -- \\
\hline \multirow[t]{3}{*}{ Clitellata } & Haplotaxida & Naididae & -- & -- & -- & -- & -- & -- & -- & -- \\
\hline & & Tubificidae & -- & -- & -- & -- & 71.0 & 3.1 & 1.9 & 4.6 \\
\hline & & Other Oligocheata ${ }^{1}$ & -- & -- & -- & -- & -- & -- & -- & -- \\
\hline \multirow[t]{2}{*}{ Malacostraca } & Amphipoda & Corophiidae & 3.3 & 0.9 & -- & -- & -- & -- & -- & -- \\
\hline & & Gammaridae & -- & -- & -- & -- & -- & -- & -- & 0.5 \\
\hline \multirow[t]{2}{*}{ Ostracoda } & Podocopa & Cytherideidae & 1.3 & 0.1 & -- & 0.1 & -- & 23.7 & 0.05 & -- \\
\hline & Ostracoda & Other Ostracoda & -- & -- & -- & -- & -- & -- & -- & -- \\
\hline Branchiopoda & Cladocera & Daphniidae & -- & -- & -- & -- & -- & -- & -- & -- \\
\hline Maxillopoda & Copepoda & Other Copepoda & -- & -- & -- & -- & -- & -- & -- & -- \\
\hline Nematoda $^{1}$ & Nematoda & Other Nematoda & 46.0 & -- & -- & -- & -- & -- & 0.2 & -- \\
\hline \multirow[t]{2}{*}{ Gastropoda } & Basommatophora & Physidae & -- & -- & -- & -- & -- & -- & -- & -- \\
\hline & & Other Gastropoda & -- & -- & -- & -- & -- & -- & 0.4 & -- \\
\hline
\end{tabular}


Table 6. Percent relative abundance of macro invertebrates collected from saline habitat ponds (SHP) and references sites, Ecosystem Monitoring Project, Salton Sea, California, fall 2006-fall 2008.-Continued.

[Totals represent 9 Ekman benthic grab and 3 D-ring sweep samples at each site, enumerated to the nearest taxonomic class, order, and/or family. Relative abundance for taxa with less than 10 individuals at any sampling period and site are not listed. Pond 4, hypersaline intolerant taxa (that is, non-Ephydridae) encountered in Pond 4 after fall 2006 typically were dead at time of collection. Wind and/or water flow through the SHP was the probable reason for their occurrence in Pond 4. --, sites with no invertebrates]

\begin{tabular}{|c|c|c|c|c|c|c|c|c|c|c|}
\hline \multirow[b]{3}{*}{ Class } & \multirow[b]{3}{*}{ Order } & \multirow[b]{3}{*}{ Family } & \multicolumn{8}{|c|}{ Spring 2007} \\
\hline & & & \multicolumn{4}{|c|}{ SHP } & \multicolumn{4}{|c|}{ Reference } \\
\hline & & & Pond 1 & Pond 2 & Pond 3 & Pond 4 & $\begin{array}{c}\text { Alamo } \\
\text { River }\end{array}$ & $\begin{array}{c}\text { Salton } \\
\text { Sea }\end{array}$ & $\begin{array}{c}\text { Freshmater } \\
\text { Marsh }\end{array}$ & D-pond \\
\hline \multirow[t]{2}{*}{ Polychaeta } & Capitellida & Capitellidae & 11.9 & 14.3 & -- & -- & 0.3 & 0.1 & -- & 0.01 \\
\hline & Aciculata & Nereidae & -- & -- & -- & -- & 0.3 & 0.5 & -- & -- \\
\hline \multirow[t]{10}{*}{ Insecta } & Ephemeroptera & Baetidae & -- & -- & -- & -- & -- & -- & -- & -- \\
\hline & Diptera & Ceratopogonidae & -- & -- & -- & -- & -- & -- & 0.2 & -- \\
\hline & & Chironomidae & 69.2 & 3.2 & -- & 1.1 & 23.5 & 2.7 & 14.4 & 2.9 \\
\hline & & Ephydridae & 0.1 & -- & 0.1 & 92.0 & -- & -- & -- & -- \\
\hline & & Other Diptera & 0.2 & -- & -- & 1.1 & 6.5 & 0.7 & 1.4 & 0.02 \\
\hline & Hemiptera & Corixidae & 6.5 & 29.8 & 99.1 & 4.0 & 0.7 & 15.4 & 32.4 & 0.4 \\
\hline & & Notonectidae & -- & -- & -- & -- & -- & -- & -- & -- \\
\hline & & Aphididae & -- & -- & -- & -- & -- & -- & -- & -- \\
\hline & & Other Hemiptera & -- & -- & -- & -- & 0.3 & 0.03 & -- & -- \\
\hline & Coleoptera & Dytiscidae & -- & -- & -- & -- & -- & -- & 0.05 & -- \\
\hline \multirow[t]{3}{*}{ Clitellata } & Haplotaxida & Naididae & -- & -- & -- & -- & -- & -- & -- & -- \\
\hline & & Tubificidae & -- & -- & -- & -- & 11.8 & -- & 0.3 & -- \\
\hline & & Other Oligocheata $^{1}$ & -- & -- & -- & -- & 16.7 & -- & 3.1 & 1.5 \\
\hline \multirow[t]{2}{*}{ Malacostraca } & Amphipoda & Corophiidae & 8.3 & 46.3 & 0.6 & -- & -- & -- & -- & -- \\
\hline & & Gammaridae & -- & -- & -- & -- & -- & -- & 0.05 & 0.03 \\
\hline \multirow[t]{2}{*}{ Ostracoda } & Podocopa & Cytherideidae & 3.6 & 1.2 & 0.0 & 1.7 & 3.3 & 75.8 & 14.4 & 0.1 \\
\hline & Ostracoda & Other Ostracoda & -- & -- & -- & -- & -- & -- & -- & -- \\
\hline Branchiopoda & Cladocera & Daphniidae & -- & -- & -- & -- & 2.3 & 1.5 & 27.6 & 94.8 \\
\hline Maxillopoda & Copepoda & Other Copepoda & -- & -- & -- & -- & 32.7 & 3.0 & 2.9 & 0.02 \\
\hline Nematoda $^{1}$ & Nematoda & Other Nematoda & 0.3 & 5.2 & 0.04 & -- & 1.6 & 0.2 & 3.2 & 0.2 \\
\hline \multirow[t]{2}{*}{ Gastropoda } & Basommatophora & Physidae & -- & -- & -- & -- & -- & -- & -- & -- \\
\hline & & Other Gastropoda & -- & -- & -- & -- & -- & -- & -- & 0.01 \\
\hline
\end{tabular}


Table 6. Percent relative abundance of macro invertebrates collected from saline habitat ponds (SHP) and references sites, Ecosystem Monitoring Project, Salton Sea, California, fall 2006-fall 2008.-Continued.

[Totals represent 9 Ekman benthic grab and 3 D-ring sweep samples at each site, enumerated to the nearest taxonomic class, order, and/or family. Relative abundance for taxa with less than 10 individuals at any sampling period and site are not listed. Pond 4, hypersaline intolerant taxa (that is, non-Ephydridae) encountered in Pond 4 after fall 2006 typically were dead at time of collection. Wind and/or water flow through the SHP was the probable reason for their occurrence in Pond 4. --, sites with no invertebrates]

\begin{tabular}{|c|c|c|c|c|c|c|c|c|c|c|}
\hline \multirow[b]{3}{*}{ Class } & \multirow[b]{3}{*}{ Order } & \multirow[b]{3}{*}{ Family } & \multicolumn{8}{|c|}{ Fall 2007} \\
\hline & & & \multicolumn{4}{|c|}{ SHP } & \multicolumn{4}{|c|}{ Reference } \\
\hline & & & Pond 1 & Pond 2 & Pond 3 & Pond 4 & $\begin{array}{l}\text { Alamo } \\
\text { River }\end{array}$ & $\begin{array}{c}\text { Salton } \\
\text { Sea }\end{array}$ & $\begin{array}{c}\text { Freshmater } \\
\text { Marsh }\end{array}$ & D-pond \\
\hline \multirow[t]{2}{*}{ Polychaeta } & Capitellida & Capitellidae & 8.6 & 13.5 & 0.1 & -- & 2.2 & 6.9 & -- & -- \\
\hline & Aciculata & Nereidae & -- & -- & -- & -- & 15.6 & -- & -- & -- \\
\hline \multirow[t]{11}{*}{ Insecta } & Ephemeroptera & Baetidae & -- & -- & -- & -- & -- & -- & -- & -- \\
\hline & Diptera & Ceratopogonidae & -- & -- & -- & -- & -- & -- & -- & -- \\
\hline & & Chironomidae & 28.8 & 6.4 & 0.3 & 0.9 & 7.8 & 0.4 & 48.7 & 69.0 \\
\hline & & Ephydridae & -- & 1.3 & 7.3 & 88.3 & 3.3 & 0.8 & 0.5 & -- \\
\hline & & Other Diptera & -- & -- & -- & -- & -- & -- & -- & -- \\
\hline & Hemiptera & Corixidae & 0.4 & 16.4 & 91.6 & 10.1 & 4.4 & 13.4 & 19.2 & 16.5 \\
\hline & & Notonectidae & -- & -- & -- & -- & -- & -- & -- & -- \\
\hline & & Aphididae & -- & -- & -- & -- & -- & -- & -- & -- \\
\hline & & Other Hemiptera & -- & -- & -- & -- & -- & -- & -- & -- \\
\hline & Coleoptera & Dytiscidae & -- & -- & -- & -- & -- & -- & -- & -- \\
\hline & & Hydrophilidae & 0.0 & -- & 0.2 & -- & 2.2 & -- & 0.1 & -- \\
\hline \multirow[t]{3}{*}{ Clitellata } & Haplotaxida & Naididae & -- & -- & -- & -- & -- & -- & -- & -- \\
\hline & & $\begin{array}{l}\text { Tubificidae } \\
\text { Other }\end{array}$ & 0.0 & 0.7 & -- & -- & 64.4 & 54.7 & 18.1 & 8.3 \\
\hline & & Oligocheata $^{1}$ & -- & -- & -- & -- & -- & 2.0 & 1.9 & -- \\
\hline \multirow[t]{2}{*}{ Malacostraca } & Amphipoda & Corophiidae & 55.3 & 5.9 & 0.2 & -- & -- & -- & -- & -- \\
\hline & & Gammaridae & -- & 0.03 & -- & -- & -- & -- & -- & -- \\
\hline \multirow[t]{2}{*}{ Ostracoda } & Podocopa & Cytherideidae & 3.9 & 46.4 & -- & 0.7 & -- & 21.9 & 10.2 & -- \\
\hline & Ostracoda & Other Ostracoda & -- & -- & -- & -- & -- & -- & -- & -- \\
\hline Branchiopoda & Cladocera & Daphniidae & -- & -- & -- & -- & -- & -- & -- & -- \\
\hline Maxillopoda & Copepoda & Other Copepoda & 1.4 & 9.4 & 0.5 & -- & -- & -- & -- & 5.7 \\
\hline Nematoda $^{1}$ & Nematoda & Other Nematoda & 1.5 & -- & -- & -- & -- & -- & 0.8 & -- \\
\hline \multirow[t]{2}{*}{ Gastropoda } & Basommatophora & Physidae & -- & -- & -- & -- & -- & -- & 0.6 & 0.5 \\
\hline & & Other Gastropoda & -- & -- & -- & -- & -- & -- & -- & -- \\
\hline
\end{tabular}


Table 6. Percent relative abundance of macro invertebrates collected from saline habitat ponds (SHP) and references sites, Ecosystem Monitoring Project, Salton Sea, California, fall 2006-fall 2008.-Continued.

[Totals represent 9 Ekman benthic grab and 3 D-ring sweep samples at each site, enumerated to the nearest taxonomic class, order, and/or family. Relative abundance for taxa with less than 10 individuals at any sampling period and site are not listed. Pond 4, hypersaline intolerant taxa (that is, non-Ephydridae) encountered in Pond 4 after fall 2006 typically were dead at time of collection. Wind and/or water flow through the SHP was the probable reason for their occurrence in Pond 4. --, sites with no invertebrates]

\begin{tabular}{|c|c|c|c|c|c|c|c|c|c|c|c|}
\hline \multirow[b]{3}{*}{ Class } & \multirow[b]{3}{*}{ Order } & \multirow[b]{3}{*}{ Family } & \multicolumn{9}{|c|}{ Spring 2008} \\
\hline & & & \multicolumn{4}{|c|}{ SHP } & \multicolumn{5}{|c|}{ Reference } \\
\hline & & & Pond 1 & Pond 2 & Pond 3 & Pond 4 & $\begin{array}{l}\text { Alamo } \\
\text { River }\end{array}$ & $\begin{array}{c}\text { Salton } \\
\text { Sea }\end{array}$ & $\begin{array}{c}\text { Freshwater } \\
\text { Marsh }\end{array}$ & D-pond & Hazard \\
\hline \multirow[t]{2}{*}{ Polychaeta } & Capitellida & Capitellidae & 0.9 & 30.3 & 1.2 & -- & 1.6 & 0.02 & 0.1 & -- & 0.2 \\
\hline & Aciculata & Nereidae & -- & -- & -- & -- & 0.8 & -- & -- & -- & -- \\
\hline \multirow[t]{11}{*}{ Insecta } & Ephemeroptera & Baetidae & -- & -- & -- & -- & -- & -- & -- & -- & -- \\
\hline & Diptera & Ceratopogonidae & -- & -- & -- & -- & -- & -- & 0.3 & 0.03 & -- \\
\hline & & Chironomidae & 45.0 & 11.8 & 0.1 & 0.0 & 12.4 & 3.0 & 34.6 & 30.4 & 37.1 \\
\hline & & Ephydridae & -- & -- & 0.1 & 68.9 & -- & 0.05 & 0.03 & -- & 0.03 \\
\hline & & Other Diptera & -- & -- & 0.0 & 1.6 & 1.6 & -- & 0.1 & 0.0 & 0.03 \\
\hline & Hemiptera & Corixidae & 6.6 & 2.8 & 97.4 & 21.3 & 18.9 & 77.2 & 8.5 & 5.9 & 18.5 \\
\hline & & Notonectidae & -- & -- & -- & -- & -- & -- & 0.03 & -- & 0.03 \\
\hline & & Aphididae & -- & 0.03 & -- & -- & 1.2 & 0.03 & 1.2 & 0.03 & -- \\
\hline & & Other Hemiptera & -- & -- & -- & -- & -- & -- & 0.5 & -- & -- \\
\hline & Coleoptera & Dytiscidae & -- & -- & -- & -- & -- & -- & -- & -- & -- \\
\hline & & Hydrophilidae & -- & -- & -- & -- & -- & -- & -- & -- & 0.1 \\
\hline \multirow[t]{3}{*}{ Clitellata } & Haplotaxida & Naididae & -- & -- & -- & -- & 0.8 & -- & 0.1 & 0.0 & 0.7 \\
\hline & & Tubificidae & 0.03 & 1.2 & -- & -- & 46.6 & -- & 21.4 & 27.6 & 1.6 \\
\hline & & Other Oligocheata ${ }^{1}$ & 0.1 & 0.6 & -- & -- & 1.2 & -- & 0.6 & -- & 2.0 \\
\hline \multirow[t]{2}{*}{ Malacostraca } & Amphipoda & Corophiidae & 3.6 & 31.4 & 1.2 & -- & -- & -- & 0.03 & -- & -- \\
\hline & & Gammaridae & -- & -- & -- & -- & -- & -- & -- & 0.4 & -- \\
\hline \multirow[t]{2}{*}{ Ostracoda } & Podocopa & Cytherideidae & 14.2 & 18.6 & 0.04 & -- & 2.0 & 11.4 & 0.03 & 0.1 & 2.1 \\
\hline & Ostracoda & Other Ostracoda & 13.4 & -- & -- & -- & -- & -- & 15.1 & -- & 0.2 \\
\hline Branchiopoda & Cladocera & Daphniidae & -- & -- & 0.03 & 8.2 & 6.4 & 2.9 & 15.3 & 32.7 & 18.7 \\
\hline Maxillopoda & Copepoda & Other Copepoda & 16.1 & 3.1 & -- & -- & 6.0 & 5.3 & 1.7 & 1.3 & 17.6 \\
\hline Nematoda $^{1}$ & Nematoda & Other Nematoda & -- & 0.3 & -- & -- & 0.4 & -- & 0.2 & 1.4 & 0.5 \\
\hline
\end{tabular}


Table 6. Percent relative abundance of macro invertebrates collected from saline habitat ponds (SHP) and references sites, Ecosystem Monitoring Project, Salton Sea, California, fall 2006-fall 2008.-Continued.

[Totals represent 9 Ekman benthic grab and 3 D-ring sweep samples at each site, enumerated to the nearest taxonomic class, order, and/or family. Relative abundance for taxa with less than 10 individuals at any sampling period and site are not listed. Pond 4, hypersaline intolerant taxa (that is, non-Ephydridae) encountered in Pond 4 after fall 2006 typically were dead at time of collection. Wind and/or water flow through the SHP was the probable reason for their occurrence in Pond 4. --, sites with no invertebrates]

\begin{tabular}{|c|c|c|c|c|c|c|c|c|c|c|}
\hline \multirow[b]{3}{*}{ Class } & \multirow[b]{3}{*}{ Order } & \multirow[b]{3}{*}{ Family } & \multicolumn{8}{|c|}{ Fall 2008} \\
\hline & & & \multicolumn{4}{|c|}{ SHP } & \multicolumn{4}{|c|}{ Reference } \\
\hline & & & Pond 1 & Pond 2 & Pond 3 & Pond 4 & $\begin{array}{l}\text { Alamo } \\
\text { River }\end{array}$ & $\begin{array}{c}\text { Salton } \\
\text { Sea }\end{array}$ & $\begin{array}{c}\text { Freshwater } \\
\text { Marsh }\end{array}$ & Hazard \\
\hline \multirow[t]{2}{*}{ Polychaeta } & Capitellida & Capitellidae & -- & 20.3 & 0.01 & -- & 0.3 & -- & -- & -- \\
\hline & Aciculata & Nereidae & -- & -- & -- & -- & 0.3 & -- & -- & -- \\
\hline \multirow[t]{11}{*}{ Insecta } & Ephemeroptera & Baetidae & -- & -- & -- & -- & -- & -- & -- & 4.7 \\
\hline & Diptera & Ceratopogonidae & -- & -- & -- & -- & -- & -- & 0.4 & -- \\
\hline & & Chironomidae & 23.9 & 15.8 & 0.05 & -- & 85.7 & 34.9 & 52.6 & 23.8 \\
\hline & & Ephydridae & 0.1 & -- & 0.1 & 94.2 & -- & -- & -- & -- \\
\hline & & Other Diptera & 0.02 & -- & -- & -- & 0.5 & 0.03 & -- & 0.05 \\
\hline & Hemiptera & Corixidae & 54.3 & 50.3 & 99.9 & 5.8 & 4.0 & 48.5 & 14.2 & 33.8 \\
\hline & & Notonectidae & -- & -- & -- & -- & -- & 0.5 & -- & 0.02 \\
\hline & & Aphididae & -- & -- & -- & -- & 0.3 & -- & 0.4 & -- \\
\hline & & Other Hemiptera & -- & -- & -- & -- & -- & -- & 1.2 & -- \\
\hline & Coleoptera & Dytiscidae & -- & -- & -- & -- & -- & -- & -- & 0.5 \\
\hline & & Hydrophilidae & 0.02 & 0.03 & -- & -- & -- & 0.03 & -- & 1.5 \\
\hline \multirow[t]{3}{*}{ Clitellata } & Haplotaxida & Naididae & -- & -- & -- & -- & -- & -- & 5.5 & -- \\
\hline & & $\begin{array}{l}\text { Tubificidae } \\
\text { Other }\end{array}$ & -- & -- & -- & -- & 6.2 & -- & 18.2 & -- \\
\hline & & Oligocheata $^{1}$ & -- & -- & -- & -- & -- & -- & 0.4 & -- \\
\hline \multirow[t]{2}{*}{ Malacostraca } & Amphipoda & Corophiidae & -- & -- & -- & -- & -- & -- & -- & -- \\
\hline & & Gammaridae & -- & -- & -- & -- & -- & -- & -- & -- \\
\hline \multirow[t]{2}{*}{ Ostracoda } & Podocopa & Cytherideidae & -- & -- & -- & -- & -- & -- & -- & -- \\
\hline & Ostracoda & Other Ostracoda & 21.5 & 13.7 & -- & -- & -- & 15.9 & 5.9 & 1.1 \\
\hline ranchiopoda & Cladocera & Daphniidae & 0.1 & -- & -- & -- & 1.3 & -- & -- & 34.5 \\
\hline Maxillopoda & Copepoda & Other Copepoda & 0.1 & -- & -- & -- & 1.3 & 0.1 & -- & -- \\
\hline Nematoda $^{1}$ & Nematoda & Other Nematoda & -- & -- & -- & -- & -- & -- & -- & 0.1 \\
\hline \multirow[t]{2}{*}{ Gastropoda } & Basommatophora & Physidae & -- & -- & -- & -- & -- & -- & 1.2 & 0.02 \\
\hline & & Other Gastropoda & -- & -- & -- & -- & -- & -- & -- & -- \\
\hline
\end{tabular}

${ }^{1}$ Phylum. 
Table 7. Percent relative abundance of zooplankton collected by taxonomic class and location, Ecosystem Monitoring Project, Salton Sea, California, fall 2006-fall 2008.

[Reported results are averages for sample sizes greater than one. SHP, saline habitat ponds. 0, less than 1 percent]

\begin{tabular}{|c|c|c|c|c|c|c|c|c|c|}
\hline \multirow[b]{3}{*}{ Class } & \multirow[b]{3}{*}{ Order } & \multicolumn{8}{|c|}{ Fall 2006} \\
\hline & & \multicolumn{4}{|c|}{ SHP } & \multicolumn{4}{|c|}{ Reference } \\
\hline & & Pond 1 & Pond 2 & Pond 3 & Pond 4 & $\begin{array}{l}\text { Alamo } \\
\text { River }\end{array}$ & $\begin{array}{l}\text { Salton } \\
\text { Sea }\end{array}$ & $\begin{array}{c}\text { Freshwater } \\
\text { Marsh }\end{array}$ & D-pond \\
\hline Insecta & Hemiptera & 0 & 5 & 6 & 15 & 0 & 0 & 0 & 0 \\
\hline \multirow[t]{4}{*}{ Copepoda } & Cyclopoida & 59 & 42 & 57 & 55 & 0 & 32 & 0 & 10 \\
\hline & Calanoida & 0 & 0 & 0 & 0 & 0 & 0 & 0 & 8 \\
\hline & Harpacticoida & 2 & 17 & 32 & 13 & 0 & 39 & 0 & 2 \\
\hline & Nauplii & 10 & 18 & 3 & 0 & 0 & 28 & 0 & 0 \\
\hline Oligochaeta & & 0 & 0 & 0 & 0 & 0 & 0 & 0 & 1 \\
\hline Ostracoda & & 0 & 0 & 2 & 8 & 94 & 1 & 100 & 66 \\
\hline Amphipoda & & 0 & 0 & 0 & 0 & 0 & 0 & 0 & 0 \\
\hline Branchiopoda & Cladocera & 0 & 0 & 0 & 0 & 0 & 0 & 0 & 2 \\
\hline Monogononta & Ploima & 27 & 17 & 1 & 5 & 6 & 1 & 0 & 11 \\
\hline Insecta $^{1}$ & larvae & 0 & 0 & 0 & 3 & 0 & 0 & 0 & 0 \\
\hline \multirow[t]{3}{*}{ Nematoda $^{1,2}$} & & 0 & 0 & 0 & 3 & 0 & 0 & 0 & 0 \\
\hline & & \multicolumn{8}{|c|}{ Spring 2007} \\
\hline & & \multicolumn{4}{|c|}{ SHP } & \multicolumn{4}{|c|}{ Reference } \\
\hline Class & Order & Pond 1 & Pond 2 & Pond 3 & Pond 4 & $\begin{array}{c}\text { Alamo } \\
\text { River }\end{array}$ & $\begin{array}{c}\text { Salton } \\
\text { Sea }\end{array}$ & $\begin{array}{c}\text { Freshwater } \\
\text { Marsh }\end{array}$ & D-pond \\
\hline Insecta & Hemiptera & 1 & $\left({ }^{3}\right)$ & 56 & 13 & 0 & 1 & 1 & ()$\left.^{4}\right)$ \\
\hline \multirow{4}{*}{ Copepoda } & Cyclopoida & 5 & $\left({ }^{3}\right)$ & 6 & 0 & 85 & 2 & 12 & $\left(4^{4}\right)$ \\
\hline & Calanoida & 71 & $\left({ }^{3}\right)$ & 0 & 0 & 0 & 7 & 3 & $\left({ }^{4}\right)$ \\
\hline & Harpacticoida & 23 & $\left({ }^{3}\right)$ & 39 & 40 & 0 & 45 & 39 & $\left({ }^{4}\right)$ \\
\hline & Nauplii & 0 & $\left({ }^{3}\right)$ & 0 & 0 & 0 & 1 & 0 & $\left({ }^{4}\right)$ \\
\hline Oligochaeta & & 0 & $\left({ }^{3}\right)$ & 0 & 0 & 6 & 0 & 1 & $\left(4^{4}\right)$ \\
\hline Ostracoda & & 1 & $\left({ }^{3}\right)$ & 0 & 33 & 9 & 6 & 30 & $\left({ }^{4}\right)$ \\
\hline Amphipoda & & 0 & $\left({ }^{3}\right)$ & 0 & 0 & 0 & 0 & 0 & $\left({ }^{4}\right)$ \\
\hline Branchiopoda & Cladocera & 0 & $\left({ }^{3}\right)$ & 0 & 0 & 0 & 0 & 8 & $\left({ }^{4}\right)$ \\
\hline Monogononta & Ploima & 0 & $\left({ }^{3}\right)$ & 0 & 0 & 0 & 36 & 0 & $\left({ }^{4}\right)$ \\
\hline Insecta $^{1}$ & larvae & 0 & $\left({ }^{3}\right)$ & 0 & 13 & 0 & 1 & 0 & $\left({ }^{4}\right)$ \\
\hline Nematoda $^{1,2}$ & & 0 & $\left({ }^{3}\right)$ & 0 & 0 & 0 & 1 & 6 & $\left({ }^{4}\right)$ \\
\hline
\end{tabular}


Table 7. Percent relative abundance of zooplankton collected by taxonomic class and location, Ecosystem Monitoring Project, Salton Sea, California, fall 2006-fall 2008.-Continued

[Reported results are averages for sample sizes greater than one. SHP, saline habitat ponds. 0, less than 1 percent]

\begin{tabular}{|c|c|c|c|c|c|c|c|c|c|}
\hline \multirow[b]{3}{*}{ Class } & \multirow[b]{3}{*}{ Order } & \multicolumn{8}{|c|}{ Fall 2007} \\
\hline & & \multicolumn{4}{|c|}{ SHP } & \multicolumn{4}{|c|}{ Reference } \\
\hline & & Pond 1 & Pond 2 & Pond 3 & Pond 4 & $\begin{array}{c}\text { Alamo } \\
\text { River }\end{array}$ & $\begin{array}{c}\text { Salton } \\
\text { Sea }\end{array}$ & $\begin{array}{c}\text { Freshwater } \\
\text { Marsh }\end{array}$ & D-pond \\
\hline Insecta & Hemiptera & 0 & 1 & 0 & 0 & 0 & 0 & 0 & 0 \\
\hline \multirow[t]{4}{*}{ Copepoda } & Cyclopoida & 6 & 64 & 46 & 0 & 0 & 8 & 42 & 52 \\
\hline & Calanoida & 0 & 0 & 0 & 0 & 0 & 0 & 0 & 0 \\
\hline & Harpacticoida & 7 & 31 & 52 & 50 & 0 & 43 & 1 & 0 \\
\hline & Nauplii & 0 & 0 & 1 & 0 & 0 & 0 & 0 & 0 \\
\hline Oligochaeta & & 2 & 0 & 0 & 0 & 0 & 0 & 0 & 0 \\
\hline Ostracoda & & 82 & 5 & 1 & 0 & 0 & 49 & 53 & 37 \\
\hline Amphipoda & & 0 & 0 & 0 & 0 & 0 & 0 & 0 & 0 \\
\hline Branchiopoda & Cladocera & 0 & 0 & 0 & 0 & 0 & 0 & 2 & 5 \\
\hline Monogononta & Ploima & 0 & 0 & 0 & 0 & 0 & 0 & 2 & 6 \\
\hline Insecta $^{1}$ & larvae & 2 & 0 & 0 & 50 & 0 & 0 & 0 & 0 \\
\hline \multirow[t]{3}{*}{ Nematoda $^{1,2}$} & & 0 & 0 & 0 & 0 & 0 & 0 & 0 & 0 \\
\hline & & \multicolumn{8}{|c|}{ Spring 2008} \\
\hline & & \multicolumn{4}{|c|}{ SHP } & \multicolumn{4}{|c|}{ Reference } \\
\hline Class & Order & Pond 1 & Pond 2 & Pond 3 & Pond 4 & $\begin{array}{c}\text { Alamo } \\
\text { River }\end{array}$ & $\begin{array}{l}\text { Salton } \\
\text { Sea }\end{array}$ & $\begin{array}{c}\text { Freshmater } \\
\text { Marsh }\end{array}$ & D-pond \\
\hline Insecta & Hemiptera & 0 & 0 & 3 & 0 & 0 & 3 & 1 & 0 \\
\hline \multirow[t]{4}{*}{ Copepoda } & Cyclopoida & 78 & 92 & 2 & 0 & 56 & 44 & 34 & 7 \\
\hline & Calanoida & 0 & 0 & 0 & 0 & 0 & 0 & 0 & 0 \\
\hline & Harpacticoida & 3 & 7 & 91 & 0 & 21 & 45 & 16 & 0 \\
\hline & Nauplii & 0 & 0 & 0 & 0 & 0 & 0 & 0 & 0 \\
\hline Oligochaeta & & 0 & 0 & 0 & 0 & 0 & 0 & 3 & 1 \\
\hline Ostracoda & & 18 & 0 & 4 & 0 & 15 & 4 & 21 & 49 \\
\hline Amphipoda & & 0 & 0 & 0 & 0 & 0 & 0 & 0 & 0 \\
\hline Branchiopoda & Cladocera & 0 & 0 & 0 & 0 & 0 & 0 & 9 & 42 \\
\hline Monogononta & Ploima & 0 & 0 & 0 & 0 & 3 & 1 & 1 & 1 \\
\hline Insecta $^{1}$ & larvae & 0 & 0 & 0 & 0 & 5 & 1 & 4 & 0 \\
\hline Nematoda $^{1,2}$ & & 0 & 0 & 0 & 100 & 0 & 2 & 9 & 0 \\
\hline
\end{tabular}


Table 7. Percent relative abundance of zooplankton collected by taxonomic class and location, Ecosystem Monitoring Project, Salton Sea, California, fall 2006-fall 2008.-Continued

[Reported results are averages for sample sizes greater than one. SHP, saline habitat ponds. 0, less than 1 percent]

\begin{tabular}{|c|c|c|c|c|c|c|c|c|c|}
\hline \multirow[b]{3}{*}{ Class } & \multirow[b]{3}{*}{ Order } & \multicolumn{8}{|c|}{ Fall 2008} \\
\hline & & \multicolumn{4}{|c|}{ SHP } & \multicolumn{4}{|c|}{ Reference } \\
\hline & & Pond 1 & Pond 2 & Pond 3 & Pond 4 & $\begin{array}{l}\text { Alamo } \\
\text { River }\end{array}$ & $\begin{array}{c}\text { Salton } \\
\text { Sea }\end{array}$ & $\begin{array}{c}\text { Freshmater } \\
\text { Marsh }\end{array}$ & Hazard \\
\hline Insecta & Hemiptera & 1 & 4 & 44 & 82 & 0 & 3 & 0 & 4 \\
\hline \multirow[t]{4}{*}{ Copepoda } & Cyclopoida & 85 & 81 & 47 & 18 & 67 & 76 & 7 & 20 \\
\hline & Calanoida & 0 & 0 & 0 & 0 & 0 & 2 & 4 & 0 \\
\hline & Harpacticoida & 10 & 4 & 3 & 0 & 0 & 2 & 2 & 0 \\
\hline & Nauplii & 1 & 0 & 0 & 0 & 0 & 0 & 0 & 0 \\
\hline Oligochaeta & & 0 & 0 & 0 & 0 & 0 & 0 & 0 & 0 \\
\hline Ostracoda & & 2 & 12 & 6 & 0 & 0 & 13 & 87 & 0 \\
\hline Amphipoda & & 0 & 0 & 0 & 0 & 0 & 0 & 0 & 0 \\
\hline Branchiopoda & Cladocera & 0 & 0 & 0 & 0 & 0 & 0 & 0 & 76 \\
\hline Monogononta & Ploima & 0 & 0 & 0 & 0 & 33 & 3 & 0 & 0 \\
\hline Insecta $^{1}$ & larvae & 1 & 0 & 0 & 0 & 0 & 1 & 0 & 0 \\
\hline Nematoda ${ }^{1,2}$ & & 0 & 0 & 0 & 0 & 0 & 0 & 0 & 0 \\
\hline
\end{tabular}

${ }^{1}$ Benthic animals that may have been brought into the water column during sampling.

${ }^{2}$ Phylum.

${ }^{3}$ Sample lost in transit.

${ }^{4}$ Insufficient water in pond to sample. 
Table 8. Arithmetic mean values for concentrations of trace elements $(\mu \mathrm{g} / \mathrm{L})$ in water samples collected from saline habitat ponds (SHP) and reference sites, Ecosystem Monitoring Project, Salton Sea, California, fall 2006-fall 2008.

[ $\mathrm{n}=3$ for all sites and sampling periods, except for fall 2006 Alamo River $(\mathrm{n}=1)$, Freshwater Marsh $(\mathrm{n}=2)$, and Salton Sea $(n=2)$. ND, all concentrations below limit of detection (LOD), which are provided in appendix 3. NQ, element not quantified]

\begin{tabular}{|c|c|c|c|c|c|c|c|}
\hline \multirow[b]{2}{*}{ Element } & \multirow[b]{2}{*}{ Group } & \multirow[b]{2}{*}{ Site } & \multicolumn{5}{|c|}{ Sampling period } \\
\hline & & & $\begin{array}{l}\text { Fall } \\
2006\end{array}$ & $\begin{array}{c}\text { Spring } \\
2007\end{array}$ & $\begin{array}{l}\text { Fall } \\
2007\end{array}$ & $\begin{array}{c}\text { Spring } \\
2008\end{array}$ & $\begin{array}{c}\text { Fall } \\
2008\end{array}$ \\
\hline \multirow[t]{8}{*}{ Ag (Silver) } & \multirow[t]{4}{*}{ SHP } & Pond 1 & 1.51 & 1.25 & ND & ND & 1.22 \\
\hline & & Pond 2 & 2.81 & 1.29 & ND & 1.91 & ND \\
\hline & & Pond 3 & 5.05 & 3.53 & ND & 4.82 & ND \\
\hline & & Pond 4 & 12.34 & ND & ND & 17.81 & ND \\
\hline & \multirow[t]{4}{*}{ Reference } & Alamo River & 0.79 & ND & ND & ND & 0.18 \\
\hline & & Salton Sea & 3.02 & ND & ND & ND & ND \\
\hline & & Freshwater Marsh & ND & ND & ND & ND & 0.16 \\
\hline & & D-pond ${ }^{1}$ & 0.92 & ND & ND & 0.16 & ND \\
\hline \multirow[t]{8}{*}{ Al (Aluminum) } & \multirow[t]{4}{*}{ SHP } & Pond 1 & 674 & 5,147 & 2,562 & 1,774 & 464 \\
\hline & & Pond 2 & 373 & 4,538 & 1,187 & 1,597 & 245 \\
\hline & & Pond 3 & 640 & 758 & 308 & 804 & ND \\
\hline & & Pond 4 & 449 & 768 & 3,765 & 3,465 & 571 \\
\hline & \multirow[t]{4}{*}{ Reference } & Alamo River & 4,720 & 4,246 & 6,614 & 4,549 & 4,580 \\
\hline & & Salton Sea & 254 & 2,038 & 1,715 & 2,146 & 1,485 \\
\hline & & Freshwater Marsh & 1,667 & 1,030 & 1,079 & 647 & 2,160 \\
\hline & & D-pond & 729 & 2,186 & 2,448 & 2,748 & 721 \\
\hline \multirow[t]{8}{*}{ As (Arsenic) } & \multirow[t]{4}{*}{ SHP } & Pond 1 & ND & 6.5 & 7.7 & 2.1 & 7.3 \\
\hline & & Pond 2 & ND & 3.1 & 9.2 & 1.0 & 13.3 \\
\hline & & Pond 3 & ND & 6.8 & 28.9 & 2.2 & 7.8 \\
\hline & & Pond 4 & 229.7 & 6.6 & 153.0 & 13.4 & 12.9 \\
\hline & \multirow[t]{4}{*}{ Reference } & Alamo River & ND & 6.1 & 7.0 & 5.7 & 5.7 \\
\hline & & Salton Sea & 57.4 & 3.4 & 55.8 & 3.0 & 3.0 \\
\hline & & Freshwater Marsh & ND & 9.7 & 3.9 & 3.9 & 4.9 \\
\hline & & D-pond & 5.1 & 2.5 & 4.8 & 1.7 & 6.4 \\
\hline \multirow[t]{8}{*}{ B (Boron) } & \multirow[t]{4}{*}{ SHP } & Pond 1 & 2617 & 10,170 & 2,237 & 5,152 & 8,563 \\
\hline & & Pond 2 & 6,947 & 12,664 & 5,081 & 10,152 & 12,367 \\
\hline & & Pond 3 & 15,534 & 53,457 & 18,338 & 34,139 & 24,800 \\
\hline & & Pond 4 & 42,737 & 61,767 & 40,916 & 123,760 & 122,333 \\
\hline & \multirow[t]{4}{*}{ Reference } & Alamo River & 543 & 548 & 626 & 551 & 680 \\
\hline & & Salton Sea & 9,337 & 6,708 & 9,492 & 3,336 & 2,890 \\
\hline & & Freshwater Marsh & 528 & 1,027 & 591 & 1,488 & 894 \\
\hline & & D-pond & 1,206 & 826 & 763 & 725 & 422 \\
\hline \multirow[t]{8}{*}{ Ba (Barium) } & \multirow[t]{4}{*}{ SHP } & Pond 1 & 74.9 & 217.2 & 150.7 & 114.9 & 89.8 \\
\hline & & Pond 2 & 70.7 & 152.6 & 102.7 & 102.9 & 89.9 \\
\hline & & Pond 3 & 90.4 & 46.8 & 71.3 & 52.5 & 104.7 \\
\hline & & Pond 4 & 69.1 & 34.1 & 83.5 & 39.9 & 116.3 \\
\hline & \multirow[t]{4}{*}{ Reference } & Alamo River & 161.5 & 150.0 & 176.3 & 136.7 & 130.3 \\
\hline & & Salton Sea & 100.0 & 124.0 & 127.3 & 115.4 & 101.3 \\
\hline & & Freshwater Marsh & 141.8 & 102.2 & 117.7 & 91.2 & 127.7 \\
\hline & & D-pond & 177.3 & 166.2 & 190.0 & 182.6 & 82.4 \\
\hline
\end{tabular}


Table 8. Arithmetic mean values for concentrations of trace elements $(\mu \mathrm{g} / \mathrm{L})$ in water samples collected from saline habitat ponds (SHP) and reference sites, Ecosystem Monitoring Project, Salton Sea, California, fall 2006-fall 2008.-Continued

[ $\mathrm{n}=3$ for all sites and sampling periods, except for fall 2006 Alamo River $(\mathrm{n}=1)$, Freshwater Marsh $(\mathrm{n}=2)$, and Salton Sea $(n=2)$. ND, all concentrations below limit of detection (LOD), which are provided in appendix 3.

NQ, element not quantified]

\begin{tabular}{|c|c|c|c|c|c|c|c|}
\hline \multirow[b]{2}{*}{ Element } & \multirow[b]{2}{*}{ Group } & \multirow[b]{2}{*}{ Site } & \multicolumn{5}{|c|}{ Sampling period } \\
\hline & & & Fall 2006 & Spring 2007 & Fall 2007 & Spring 2008 & Fall 2008 \\
\hline \multirow[t]{8}{*}{ Be (Beryllium ) } & SHP & Pond 1 & ND & 3.3 & 1.4 & 4.3 & 4.9 \\
\hline & & Pond 2 & ND & 3.7 & 3.5 & 8.8 & 10.1 \\
\hline & & Pond 3 & 2.2 & 10.1 & 7.0 & 19.5 & 21.4 \\
\hline & & Pond 4 & 6.7 & 18.1 & 45.4 & 71.5 & 86.8 \\
\hline & Reference & Alamo River & ND & 0.8 & 1.0 & 1.1 & 1.1 \\
\hline & & Salton Sea & 1.5 & 2.8 & 12.6 & 2.7 & 2.0 \\
\hline & & Freshwater Marsh & ND & 0.7 & 0.6 & 0.8 & 1.0 \\
\hline & & D-pond & ND & 0.8 & 0.8 & 0.9 & 0.8 \\
\hline \multirow[t]{8}{*}{ Cd (Cadmium) } & SHP & Pond 1 & 1.0 & 0.5 & 0.3 & 1.7 & ND \\
\hline & & Pond 2 & 2.3 & 0.6 & 1.4 & 1.3 & 2.3 \\
\hline & & Pond 3 & 2.3 & 2.0 & ND & 3.6 & 3.3 \\
\hline & & Pond 4 & ND & ND & ND & ND & ND \\
\hline & Reference & Alamo River & 0.7 & 0.3 & 0.5 & 0.5 & 0.4 \\
\hline & & Salton Sea & 1.0 & $\mathrm{ND}$ & 3.3 & ND & 0.4 \\
\hline & & Freshwater Marsh & 0.5 & 0.3 & 0.2 & 0.3 & 0.3 \\
\hline & & D-pond & 0.2 & ND & 0.2 & 0.3 & 0.2 \\
\hline \multirow[t]{8}{*}{ Co (Cobalt) } & SHP & Pond 1 & 0.6 & 2.7 & 1.3 & ND & ND \\
\hline & & Pond 2 & 0.9 & ND & 1.0 & ND & ND \\
\hline & & Pond 3 & ND & ND & ND & ND & ND \\
\hline & & Pond 4 & ND & ND & ND & ND & ND \\
\hline & Reference & Alamo River & 2.6 & 1.8 & 3.0 & 2.5 & 2.1 \\
\hline & & Salton Sea & ND & 1.4 & 5.1 & 1.2 & 0.7 \\
\hline & & Freshwater Marsh & 1.1 & 0.7 & 0.6 & 0.6 & 0.9 \\
\hline & & D-pond & 0.7 & 0.6 & 1.4 & 1.4 & 0.5 \\
\hline \multirow[t]{8}{*}{ Cr (Chromium) } & SHP & Pond 1 & 0.6 & 2.6 & 3.6 & 4.6 & 2.5 \\
\hline & & Pond 2 & ND & 1.4 & 5.7 & 7.1 & 3.9 \\
\hline & & Pond 3 & 3.4 & ND & 6.8 & 14.4 & 6.9 \\
\hline & & Pond 4 & 8.5 & ND & 48.5 & 58.3 & 30.4 \\
\hline & Reference & Alamo River & 4.6 & 3.8 & 6.8 & 4.7 & 4.5 \\
\hline & & Salton Sea & 1.8 & 0.8 & 15.7 & 3.3 & 2.0 \\
\hline & & Freshwater Marsh & 1.5 & 0.5 & 1.7 & 1.2 & 2.4 \\
\hline & & D-pond & 0.7 & 1.6 & 2.8 & 2.9 & 0.8 \\
\hline \multirow[t]{8}{*}{$\mathrm{Cu}$ (Copper) } & SHP & Pond 1 & 2.2 & 16.4 & 7.3 & 1.3 & 8.1 \\
\hline & & Pond 2 & ND & 12.7 & ND & ND & 10.2 \\
\hline & & Pond 3 & ND & 25.8 & ND & ND & 14.9 \\
\hline & & Pond 4 & ND & 23.8 & 13.7 & ND & ND \\
\hline & Reference & Alamo River & 8.2 & 8.5 & 10.8 & 13.6 & 8.4 \\
\hline & & Salton Sea & ND & 5.4 & 5.8 & 3.7 & 4.3 \\
\hline & & Freshwater Marsh & 0.5 & 0.9 & 0.3 & 3.8 & 4.3 \\
\hline & & D-pond & ND & 2.6 & 2.2 & 5.7 & 2.9 \\
\hline
\end{tabular}


Table 8. Arithmetic mean values for concentrations of trace elements $(\mu \mathrm{g} / \mathrm{L})$ in water samples collected from saline habitat ponds (SHP) and reference sites, Ecosystem Monitoring Project, Salton Sea, California, fall 2006-fall 2008.-Continued

[ $\mathrm{n}=3$ for all sites and sampling periods, except for fall 2006 Alamo River $(\mathrm{n}=1)$, Freshwater Marsh $(\mathrm{n}=2)$, and Salton Sea $(n=2)$. ND, all concentrations below limit of detection (LOD), which are provided in appendix 3.

$\mathrm{NQ}$, element not quantified]

\begin{tabular}{|c|c|c|c|c|c|c|c|}
\hline \multirow[b]{2}{*}{ Element } & \multirow[b]{2}{*}{ Group } & \multirow[b]{2}{*}{ Site } & \multicolumn{5}{|c|}{ Sampling period } \\
\hline & & & Fall 2006 & Spring 2007 & Fall 2007 & Spring 2008 & Fall 2008 \\
\hline \multirow[t]{8}{*}{ Fe (Iron) } & SHP & Pond 1 & 752 & 8,653 & 3,425 & 1,665 & 788 \\
\hline & & Pond 2 & 540 & 6,138 & 1,664 & 1,314 & 844 \\
\hline & & Pond 3 & 957 & 3,353 & 242 & 521 & 1,492 \\
\hline & & Pond 4 & 1,758 & 5,091 & 6,150 & 4,040 & 1,156 \\
\hline & Reference & Alamo River & 5,121 & 5,227 & 6,952 & 4,630 & 4,467 \\
\hline & & Salton Sea & 331 & 2,499 & 1,741 & 2,242 & 1,327 \\
\hline & & Freshwater Marsh & 1,750 & 1,447 & 1,110 & 803 & 2,620 \\
\hline & & D-pond & 669 & 2,367 & 2,530 & 2,725 & 669 \\
\hline \multirow[t]{8}{*}{ Hg (Mercury) } & SHP & Pond 1 & 0.00 & NQ & NQ & NQ & NQ \\
\hline & & Pond 2 & 0.00 & NQ & NQ & NQ & NQ \\
\hline & & Pond 3 & 0.01 & NQ & NQ & NQ & NQ \\
\hline & & Pond 4 & 0.02 & NQ & NQ & NQ & NQ \\
\hline & Reference & Alamo River & 0.01 & NQ & NQ & NQ & NQ \\
\hline & & Salton Sea & 0.01 & NQ & NQ & NQ & NQ \\
\hline & & Freshwater Marsh & 0.00 & NQ & NQ & NQ & NQ \\
\hline & & D-pond & 0.00 & NQ & NQ & NQ & NQ \\
\hline \multirow[t]{8}{*}{ Mn (Manganese) } & SHP & Pond 1 & 77 & 714 & 245 & 115 & 295 \\
\hline & & Pond 2 & 173 & 493 & 275 & 113 & 728 \\
\hline & & Pond 3 & 189 & 473 & 76 & 9 & 591 \\
\hline & & Pond 4 & 805 & 123 & 1,450 & 1,250 & 2,006 \\
\hline & Reference & Alamo River & 205 & 226 & 233 & 217 & 178 \\
\hline & & Salton Sea & 42 & 179 & 141 & 116 & 122 \\
\hline & & Freshwater Marsh & 52 & 94 & 41 & 72 & 102 \\
\hline & & D-pond & 29 & 86 & 91 & 99 & 91 \\
\hline \multirow[t]{8}{*}{ Mo (Molybdenum) } & SHP & Pond 1 & 19.3 & 16.0 & 19.5 & 16.7 & 23.2 \\
\hline & & Pond 2 & 24.6 & 33.4 & 22.1 & 27.7 & 16.5 \\
\hline & & Pond 3 & 36.5 & 29.6 & 35.4 & 17.7 & ND \\
\hline & & Pond 4 & 106.0 & 67.5 & 43.2 & ND & ND \\
\hline & Reference & Alamo River & 14.8 & 14.0 & 16.2 & 12.7 & 14.5 \\
\hline & & Salton Sea & 15.6 & 29.8 & 27.2 & 17.7 & 21.8 \\
\hline & & Freshwater Marsh & 8.3 & 11.6 & 12.1 & 9.2 & 9.9 \\
\hline & & D-pond & 24.9 & 11.9 & 16.8 & 10.3 & 12.3 \\
\hline \multirow[t]{8}{*}{ Ni (Nickel) } & SHP & Pond 1 & 3.5 & 10.0 & 4.4 & 5.5 & 2.0 \\
\hline & & Pond 2 & 7.6 & 7.8 & 4.2 & 7.1 & 3.3 \\
\hline & & Pond 3 & ND & 15.0 & 6.8 & 10.2 & ND \\
\hline & & Pond 4 & ND & 15.1 & 33.3 & 31.9 & ND \\
\hline & Reference & Alamo River & 6.8 & 7.3 & 8.4 & 6.3 & 5.7 \\
\hline & & Salton Sea & 4.2 & 4.0 & 10.5 & 3.7 & 2.4 \\
\hline & & Freshwater Marsh & 4.1 & 2.9 & 2.7 & 2.4 & 3.3 \\
\hline & & D-pond & 2.6 & 4.4 & 4.0 & 4.1 & 1.6 \\
\hline
\end{tabular}


Table 8. Arithmetic mean values for concentrations of trace elements $(\mu \mathrm{g} / \mathrm{L})$ in water samples collected from saline habitat ponds (SHP) and reference sites, Ecosystem Monitoring Project, Salton Sea, California, fall 2006-fall 2008.-Continued

[ $\mathrm{n}=3$ for all sites and sampling periods, except for fall 2006 Alamo River $(\mathrm{n}=1)$, Freshwater Marsh $(\mathrm{n}=2)$, and Salton Sea $(n=2)$. ND, all concentrations below limit of detection (LOD), which are provided in appendix 3.

NQ, element not quantified]

\begin{tabular}{|c|c|c|c|c|c|c|c|}
\hline \multirow[b]{2}{*}{ Element } & \multirow[b]{2}{*}{ Group } & \multirow[b]{2}{*}{ Site } & \multicolumn{5}{|c|}{ Sampling period } \\
\hline & & & Fall 2006 & Spring 2007 & Fall 2007 & Spring 2008 & Fall 2008 \\
\hline \multirow[t]{8}{*}{$\mathrm{Pb}$ (Lead) } & SHP & Pond 1 & 17.4 & 24.4 & 5.3 & ND & 19.4 \\
\hline & & Pond 2 & 42.7 & 8.2 & 2.7 & ND & 43.0 \\
\hline & & Pond 3 & 45.1 & 44.3 & 0.9 & 50.6 & 62.2 \\
\hline & & Pond 4 & 198.4 & 60.4 & 6.5 & ND & 319.7 \\
\hline & Reference & Alamo River & 10.3 & 7.1 & 6.0 & 4.4 & 5.1 \\
\hline & & Salton Sea & 54.3 & ND & 2.3 & 4.2 & 6.8 \\
\hline & & Freshwater Marsh & 6.8 & ND & 0.9 & ND & 4.4 \\
\hline & & D-pond & 7.9 & 2.9 & 2.4 & 2.8 & 3.0 \\
\hline \multirow[t]{8}{*}{ Sb (Antimony) } & SHP & Pond 1 & ND & 1.0 & 1.2 & 1.3 & NQ \\
\hline & & Pond 2 & ND & 0.9 & 0.6 & 0.9 & NQ \\
\hline & & Pond 3 & 40.4 & 1.2 & 1.5 & 1.2 & NQ \\
\hline & & Pond 4 & ND & 1.3 & 2.8 & 2.9 & NQ \\
\hline & Reference & Alamo River & 9.6 & 0.4 & 0.4 & 0.5 & NQ \\
\hline & & Salton Sea & 29.5 & 1.5 & 4.0 & 1.5 & NQ \\
\hline & & Freshwater Marsh & ND & 0.6 & 0.4 & 0.6 & NQ \\
\hline & & D-pond & 5.5 & 0.5 & 0.5 & 0.6 & NQ \\
\hline \multirow[t]{8}{*}{ Se (Selenium) } & SHP & Pond 1 & 3.9 & 1.9 & 2.0 & 3.0 & 2.6 \\
\hline & & Pond 2 & 2.4 & 1.9 & 0.9 & 1.9 & 1.5 \\
\hline & & Pond 3 & 2.7 & 2.7 & 1.2 & 1.6 & 1.7 \\
\hline & & Pond 4 & 3.8 & 3.0 & 3.4 & 5.7 & 3.2 \\
\hline & Reference & Alamo River & 7.0 & 5.2 & 5.9 & 5.4 & 5.9 \\
\hline & & Salton Sea & 2.1 & 3.1 & 1.9 & 3.2 & 2.0 \\
\hline & & Freshwater Marsh & 2.5 & 4.1 & 2.0 & 4.2 & 2.6 \\
\hline & & D-pond & 0.9 & 0.7 & 0.8 & 0.9 & 1.1 \\
\hline \multirow[t]{8}{*}{ Sn (Tin) } & SHP & Pond 1 & ND & 0.16 & ND & NQ & NQ \\
\hline & & Pond 2 & 0.17 & 0.15 & ND & NQ & NQ \\
\hline & & Pond 3 & 0.19 & 0.14 & ND & NQ & NQ \\
\hline & & Pond 4 & 0.42 & 0.12 & ND & NQ & NQ \\
\hline & Reference & Alamo River & ND & ND & ND & NQ & NQ \\
\hline & & Salton Sea & 0.12 & 0.04 & ND & NQ & NQ \\
\hline & & Freshwater Marsh & 0.08 & 0.05 & ND & NQ & NQ \\
\hline & & D-pond & ND & ND & ND & NQ & NQ \\
\hline \multirow[t]{8}{*}{ Tl (Thallium) } & SHP & Pond 1 & ND & 39.60 & 1.78 & ND & ND \\
\hline & & Pond 2 & ND & 24.84 & 13.35 & ND & ND \\
\hline & & Pond 3 & ND & 125.7 & 18.1 & ND & ND \\
\hline & & Pond 4 & ND & 152.8 & ND & ND & ND \\
\hline & Reference & Alamo River & 12.6 & 4.8 & 3.1 & 1.9 & 1.8 \\
\hline & & Salton Sea & ND & 20.1 & 44.8 & 5.3 & ND \\
\hline & & Freshwater Marsh & ND & 3.1 & 2.2 & 2.2 & ND \\
\hline & & D-pond & ND & 3.5 & ND & 2.1 & ND \\
\hline
\end{tabular}


Table 8. Arithmetic mean values for concentrations of trace elements $(\mu \mathrm{g} / \mathrm{L})$ in water samples collected from saline habitat ponds (SHP) and reference sites, Ecosystem Monitoring Project, Salton Sea, California, fall 2006-fall 2008.-Continued

[ $\mathrm{n}=3$ for all sites and sampling periods, except for fall 2006 Alamo River $(\mathrm{n}=1)$, Freshwater Marsh $(\mathrm{n}=2)$, and Salton Sea $(n=2)$. ND, all concentrations below limit of detection (LOD), which are provided in appendix 3.

NQ, element not quantified]

\begin{tabular}{|c|c|c|c|c|c|c|c|}
\hline \multirow[b]{2}{*}{ Element } & \multirow[b]{2}{*}{ Group } & \multirow[b]{2}{*}{ Site } & \multicolumn{5}{|c|}{ Sampling period } \\
\hline & & & Fall 2006 & Spring 2007 & Fall 2007 & Spring 2008 & Fall 2008 \\
\hline \multirow[t]{8}{*}{ V (Vanadium) } & SHP & Pond 1 & 2.9 & 11.3 & 5.5 & 2.3 & ND \\
\hline & & Pond 2 & 2.2 & 7.2 & 1.1 & ND & ND \\
\hline & & Pond 3 & 2.2 & ND & ND & ND & ND \\
\hline & & Pond 4 & 9.4 & ND & ND & ND & ND \\
\hline & Reference & Alamo River & 16.1 & 14.2 & 17.8 & 14.5 & 13.7 \\
\hline & & Salton Sea & 2.3 & 9.9 & 9.5 & 6.5 & 3.0 \\
\hline & & Freshwater Marsh & 7.1 & 8.0 & 4.3 & 4.4 & 6.9 \\
\hline & & D-pond & 7.9 & 5.6 & 6.2 & 6.0 & 3.7 \\
\hline \multirow[t]{8}{*}{ Zn (Zinc) } & SHP & Pond 1 & 11.9 & 73.0 & 31.2 & 23.2 & 24.4 \\
\hline & & Pond 2 & 14.1 & 81.1 & 17.4 & 30.7 & 43.7 \\
\hline & & Pond 3 & 11.5 & 5.6 & ND & 52.1 & 63.5 \\
\hline & & Pond 4 & ND & 20.2 & 164.7 & 137.5 & 85.2 \\
\hline & Reference & Alamo River & 25.6 & 20.3 & 28.7 & 22.4 & 27.2 \\
\hline & & Salton Sea & ND & 4.6 & 57.6 & 19.8 & 19.5 \\
\hline & & Freshwater Marsh & 6.0 & 2.6 & 6.1 & 3.3 & 17.2 \\
\hline & & D-pond & 3.9 & 7.6 & 11.3 & 13.1 & 13.1 \\
\hline
\end{tabular}

${ }^{1}$ D-pond was dry in fall 2008, Salton Sea National Wildlife Refuge Hazard Pond sampled in its place.

${ }^{2} A$ value of $1 / 2$ the LOD was substituted when calculating averages for sites with partial analyte detection. 
Table 9. Arithmetic mean values for concentrations of $p, p^{\prime}$ DDE $(\mathrm{mg} / \mathrm{L})$ in surface-water samples collected from saline habitat ponds (SHP) and reference sites, Ecosystem Monitoring Project, Salton Sea, California, fall 2006-fall 2008.

[ $\mathrm{n}=3$ for all sites and sampling periods, except for fall 2006 Freshwater Marsh $(\mathrm{n}=2)$, Alamo River $(n=1)$, and Salton Sea $(n=2)$. Sampling period: Spring 2008 was not sampled. ND, all concentrations are below limit of detection (LOD), which are provided in appendix 4]

\begin{tabular}{llllll}
\hline & & \multicolumn{4}{c}{ Sampling period } \\
\cline { 3 - 6 } \multicolumn{1}{c}{ Group } & & Fall & Spring & Fall & Fall \\
\hline \multirow{2}{*}{ SHP } & Sond 1 & 2006 & 2007 & 2007 & 2008 \\
& Pond 2 & ND & ND & ND & 0.00001 \\
& Pond 3 & ND & ND & ND & ND \\
& Pond 4 & ND & ND & ND & ND \\
Reference & ND & ND & ND & ND \\
& Alamo River & ND & ND & ND & 0.00002 \\
& Salton Sea & ND & ND & ND & ND \\
& Freshwater Marsh $^{*}$ & ND & ND & ND & 0.00001 \\
& D-pond $^{1}$ & ND & ND & ND & ND \\
\hline
\end{tabular}

${ }^{1}$ D-pond was dry in fall 2008, Salton Sea National Wildlife Refuge Hazard Pond sampled in its place. 
Table 10. Arithmetic mean values for concentrations of trace elements $(\mu \mathrm{g} / \mathrm{g}$, dry weight) in sediment samples collected from saline habitat ponds (SHP) and reference sites, Ecosystem Monitoring Project, Salton Sea, California, spring 2006-fall 2008.

[ $\mathrm{n}=3$ for all sites and sampling periods, except for spring 2006 Salton Sea $(\mathrm{n}=2)$, Alamo River, Freshwater Marsh, and D-Pond $(\mathrm{n}=1)$. Element definitions are given in table 8. ND, all concentrations below limit of detection (LOD), which are provided in appendix 5. NQ, element not quantified]

\begin{tabular}{|c|c|c|c|c|c|c|c|c|}
\hline \multirow[b]{2}{*}{ Element } & \multirow[b]{2}{*}{ Group } & \multirow[b]{2}{*}{ Site } & \multicolumn{6}{|c|}{ Sampling period } \\
\hline & & & $\begin{array}{c}\text { Spring } \\
2006\end{array}$ & $\begin{array}{l}\text { Fall } \\
2006 \\
\end{array}$ & $\begin{array}{c}\text { Spring } \\
2007\end{array}$ & $\begin{array}{l}\text { Fall } \\
2007 \\
\end{array}$ & $\begin{array}{c}\text { Spring } \\
2008 \\
\end{array}$ & $\begin{array}{c}\text { Fall } \\
2008 \\
\end{array}$ \\
\hline \multirow[t]{8}{*}{ Ag } & SHP & Pond 1 & 0.757 & 0.029 & 0.084 & 0.291 & 0.144 & 0.197 \\
\hline & & Pond 2 & 0.965 & 0.109 & 0.091 & 0.331 & 0.086 & 0.406 \\
\hline & & Pond 3 & 0.683 & ND & ND & 0.141 & ND & 0.079 \\
\hline & & Pond 4 & 0.668 & ND & ND & 0.143 & ND & 0.015 \\
\hline & Reference & Alamo River & 0.747 & ND & ND & 0.104 & ND & ND \\
\hline & & Salton Sea & 0.740 & ND & ND & 0.104 & ND & 0.052 \\
\hline & & Freshwater Marsh & 0.687 & ND & ND & 0.150 & ND & 0.048 \\
\hline & & D-pond ${ }^{1}$ & 0.428 & ND & ND & 0.089 & ND & ND \\
\hline \multirow[t]{8}{*}{$\mathrm{Al}$} & SHP & Pond 1 & 41,208 & 56,307 & 48,877 & 52,133 & 46,780 & 50,084 \\
\hline & & Pond 2 & 33,126 & 37,575 & 41,277 & 38,561 & 40,616 & 46,703 \\
\hline & & Pond 3 & 41,342 & 50,419 & 46,398 & 38,016 & 38,823 & 35,507 \\
\hline & & Pond 4 & 39,915 & 51,888 & 46,987 & 38,639 & 35,991 & 34,220 \\
\hline & Reference & Alamo River & 44,043 & 51,022 & 50,590 & 49,795 & 43,119 & 49,036 \\
\hline & & Salton Sea & 44,148 & 39,440 & 45,308 & 40,279 & 47,419 & 53,922 \\
\hline & & Freshwater Marsh & 50,363 & 48,642 & 48,095 & 51,102 & 50,056 & 54,068 \\
\hline & & D-pond & 34,268 & 53,994 & 48,242 & 49,209 & 49,123 & 69,172 \\
\hline \multirow[t]{8}{*}{ As } & SHP & Pond 1 & 4.55 & 6.25 & 10.84 & 7.71 & 11.64 & 12.84 \\
\hline & & Pond 2 & 7.55 & 7.22 & 10.65 & 7.53 & 10.08 & 14.07 \\
\hline & & Pond 3 & 3.82 & 3.78 & 6.95 & 2.17 & 5.48 & 4.92 \\
\hline & & Pond 4 & 3.19 & 2.81 & 5.86 & 3.63 & 5.03 & 5.43 \\
\hline & Reference & Alamo River & 2.36 & 3.24 & 3.94 & 4.83 & 3.05 & 5.39 \\
\hline & & Salton Sea & 4.02 & 2.81 & 5.43 & 3.49 & 4.06 & 6.37 \\
\hline & & Freshwater Marsh & 10.44 & 4.69 & 8.18 & 6.41 & 8.08 & 13.50 \\
\hline & & D-pond & ND & 3.99 & 4.89 & 5.82 & 4.75 & 8.37 \\
\hline \multirow[t]{8}{*}{ B } & SHP & Pond 1 & 128 & 61.2 & 63.6 & 42.3 & 53.0 & 51.4 \\
\hline & & Pond 2 & 133 & 65.9 & 77.9 & 56.3 & 79.5 & 86.0 \\
\hline & & Pond 3 & 130 & 64.0 & 87.1 & 75.5 & 113.5 & 110.3 \\
\hline & & Pond 4 & 120 & 95.6 & 117.92 & 125 & 181 & 196 \\
\hline & Reference & Alamo River & 30.8 & 13.2 & 19.4 & 14.3 & 22.1 & 15.1 \\
\hline & & Salton Sea & 86.5 & 72.6 & 68.9 & 34.7 & 54.0 & 35.3 \\
\hline & & Freshwater Marsh & 53.2 & 20.8 & 29.5 & 21.9 & 28.3 & 30.7 \\
\hline & & D-pond & 21.3 & 19.0 & 20.1 & 16.2 & 17.9 & 24.9 \\
\hline \multirow[t]{8}{*}{$\mathrm{Ba}$} & SHP & Pond 1 & 535 & 692 & 696 & 711 & 763 & 816 \\
\hline & & Pond 2 & 536 & 599 & 647 & 527 & 599 & 685 \\
\hline & & Pond 3 & 338 & 398 & 385 & 311 & 321 & 283 \\
\hline & & Pond 4 & 346 & 437 & 382 & 311 & 295 & 264 \\
\hline & Reference & Alamo River & 525 & 529 & 542 & 530 & 540 & 539 \\
\hline & & Salton Sea & 421 & 334 & 439 & 419 & 453 & 486 \\
\hline & & Freshwater Marsh & 447 & 458 & 482 & 481 & 489 & 465 \\
\hline & & D-pond & 499 & 512 & 645 & 547 & 549 & 519 \\
\hline
\end{tabular}


Table 10. Arithmetic mean values for concentrations of trace elements $(\mu \mathrm{g} / \mathrm{g}$, dry weight) in sediment samples collected from saline habitat ponds (SHP) and reference sites, Ecosystem Monitoring Project, Salton Sea, California, spring 2006-fall 2008.-Continued

[ $\mathrm{n}=3$ for all sites and sampling periods, except for spring 2006 Salton Sea $(\mathrm{n}=2)$, Alamo River, Freshwater Marsh, and D-Pond $(n=1)$. Element definitions are given in table 8. ND, all concentrations below limit of detection (LOD), which are provided in appendix 5. NQ, element not quantified]

\begin{tabular}{|c|c|c|c|c|c|c|c|c|}
\hline \multirow[b]{2}{*}{ Element } & \multirow[b]{2}{*}{ Group } & \multirow[b]{2}{*}{ Site } & \multicolumn{6}{|c|}{ Sampling period } \\
\hline & & & $\begin{array}{c}\text { Spring } \\
2006\end{array}$ & $\begin{array}{c}\text { Fall } \\
2006 \\
\end{array}$ & $\begin{array}{c}\text { Spring } \\
2007\end{array}$ & $\begin{array}{l}\text { Fall } \\
2007\end{array}$ & $\begin{array}{c}\text { Spring } \\
2008 \\
\end{array}$ & $\begin{array}{l}\text { Fall } \\
2008 \\
\end{array}$ \\
\hline \multirow[t]{8}{*}{$\mathrm{Be}$} & SHP & Pond 1 & 1.28 & 1.60 & 1.12 & 1.46 & 1.36 & 1.33 \\
\hline & & Pond 2 & 1.07 & 1.27 & 1.01 & 1.16 & 1.26 & 1.36 \\
\hline & & Pond 3 & 1.24 & 1.50 & 1.02 & 1.11 & 1.16 & 0.99 \\
\hline & & Pond 4 & 1.20 & 1.53 & 1.07 & 1.11 & 1.08 & 0.95 \\
\hline & Reference & Alamo River & 1.17 & 1.32 & 0.83 & 1.32 & 1.08 & 1.19 \\
\hline & & Salton Sea & 1.26 & 1.22 & 0.95 & 1.11 & 1.27 & 1.32 \\
\hline & & Freshwater Marsh & 1.49 & 1.39 & 0.904 & 1.45 & 1.36 & 1.40 \\
\hline & & D-pond & 0.809 & 1.49 & 0.812 & 1.30 & 1.27 & 1.73 \\
\hline \multirow[t]{8}{*}{$\mathrm{Cd}$} & SHP & Pond 1 & 0.34 & 0.38 & 0.41 & 0.75 & 0.63 & 0.49 \\
\hline & & Pond 2 & 0.29 & 0.55 & 0.37 & 0.78 & 0.66 & 0.71 \\
\hline & & Pond 3 & 0.39 & 0.36 & 0.21 & 0.32 & 0.30 & 0.26 \\
\hline & & Pond 4 & 0.36 & 0.31 & 0.25 & 0.31 & 0.24 & 0.25 \\
\hline & Reference & Alamo River & 0.29 & 0.30 & 0.32 & 0.37 & 0.29 & 0.34 \\
\hline & & Salton Sea & 0.29 & 0.31 & 0.20 & 0.31 & 0.36 & 0.39 \\
\hline & & Freshwater Marsh & 0.44 & 0.29 & 0.21 & 0.43 & 0.39 & 0.44 \\
\hline & & D-pond & 0.06 & 0.26 & 0.17 & 0.29 & 0.26 & 0.38 \\
\hline \multirow[t]{8}{*}{ Co } & SHP & Pond 1 & 6.11 & 6.45 & 7.07 & 6.62 & 5.70 & 5.60 \\
\hline & & Pond 2 & 4.62 & 4.68 & 5.52 & 4.88 & 4.78 & 5.21 \\
\hline & & Pond 3 & 6.57 & 6.67 & 6.99 & 5.04 & 4.91 & 4.62 \\
\hline & & Pond 4 & 6.32 & 6.87 & 7.16 & 5.33 & 4.58 & 4.36 \\
\hline & Reference & Alamo River & 6.40 & 5.96 & 6.76 & 6.41 & 4.81 & 5.61 \\
\hline & & Salton Sea & 6.73 & 5.33 & 6.40 & 4.92 & 5.38 & 6.39 \\
\hline & & Freshwater Marsh & 7.85 & 6.18 & 6.52 & 6.84 & 5.92 & 6.77 \\
\hline & & D-pond & 3.70 & 6.86 & 6.31 & 6.03 & 5.75 & 8.52 \\
\hline \multirow[t]{8}{*}{$\mathrm{Cr}$} & SHP & Pond 1 & 30.1 & 38.4 & 35.9 & 37.3 & 32.0 & 30.7 \\
\hline & & Pond 2 & 22.4 & 24.8 & 29.7 & 26.1 & 27.1 & 29.6 \\
\hline & & Pond 3 & 32.8 & 37.5 & 36.8 & 29.6 & 29.6 & 25.4 \\
\hline & & Pond 4 & 31.4 & 37.8 & 36.3 & 28.9 & 27.2 & 23.8 \\
\hline & Reference & Alamo River & 32.2 & 34.9 & 37.3 & 35.1 & 28.3 & 30.2 \\
\hline & & Salton Sea & 34.0 & 29.5 & 34.8 & 25.3 & 32.9 & 36.1 \\
\hline & & Freshwater Marsh & 39.4 & 33.1 & 36.5 & 37.7 & 35.6 & 36.9 \\
\hline & & D-pond & 20.7 & 38.4 & 33.4 & 35.4 & 33.7 & 47.0 \\
\hline \multirow[t]{8}{*}{$\mathrm{Cu}$} & SHP & Pond 1 & 18.4 & 20.3 & 22.8 & 22.4 & 19.4 & 17.5 \\
\hline & & Pond 2 & 18.3 & 19.8 & 23.4 & 18.1 & 22.6 & 22.8 \\
\hline & & Pond 3 & 22.0 & 24.9 & 25.3 & 19.6 & 19.7 & 17.3 \\
\hline & & Pond 4 & 21.4 & 24.8 & 23.6 & 18.0 & 17.4 & 16.3 \\
\hline & Reference & Alamo River & 19.2 & 17.7 & 19.6 & 18.9 & 13.7 & 15.1 \\
\hline & & Salton Sea & 19.6 & 16.3 & 20.8 & 13.2 & 18.3 & 19.7 \\
\hline & & Freshwater Marsh & 25.4 & 19.4 & 20.5 & 22.8 & 22.4 & 24.3 \\
\hline & & D-pond & 9.1 & 19.4 & 16.7 & 17.6 & 15.9 & 23.3 \\
\hline
\end{tabular}


Table 10. Arithmetic mean values for concentrations of trace elements $(\mu \mathrm{g} / \mathrm{g}$, dry weight) in sediment samples collected from saline habitat ponds (SHP) and reference sites, Ecosystem Monitoring Project, Salton Sea, California, spring 2006-fall 2008.-Continued

[ $\mathrm{n}=3$ for all sites and sampling periods, except for spring 2006 Salton Sea $(\mathrm{n}=2)$, Alamo River, Freshwater Marsh, and D-Pond $(\mathrm{n}=1)$. Element definitions are given in table 8. ND, all concentrations below limit of detection (LOD), which are provided in appendix 5. NQ, element not quantified]

\begin{tabular}{|c|c|c|c|c|c|c|c|c|}
\hline \multirow[b]{2}{*}{ Element } & \multirow[b]{2}{*}{ Group } & \multirow[b]{2}{*}{ Site } & \multicolumn{6}{|c|}{ Sampling period } \\
\hline & & & $\begin{array}{l}\text { Spring } \\
2006\end{array}$ & $\begin{array}{c}\text { Fall } \\
2006\end{array}$ & $\begin{array}{c}\text { Spring } \\
2007\end{array}$ & $\begin{array}{l}\text { Fall } \\
2007\end{array}$ & $\begin{array}{c}\text { Spring } \\
2008\end{array}$ & $\begin{array}{l}\text { Fall } \\
2008\end{array}$ \\
\hline \multirow[t]{8}{*}{$\mathrm{Fe}$} & SHP & Pond 1 & 21,589 & 26,883 & 25,022 & 25,405 & 24,062 & 23,668 \\
\hline & & Pond 2 & 19,220 & 21,630 & 25,103 & 21,878 & 24,316 & 25,323 \\
\hline & & Pond 3 & 20,757 & 24,697 & 23,142 & 18,767 & 19,751 & 17,058 \\
\hline & & Pond 4 & 18,987 & 25,648 & 22,716 & 17,724 & 17,719 & 15,868 \\
\hline & Reference & Alamo River & 17,055 & 19,823 & 20,249 & 18,322 & 16,060 & 18,060 \\
\hline & & Salton Sea & 19,636 & 17,180 & 20,271 & 14,431 & 20,315 & 22,275 \\
\hline & & Freshwater Marsh & 24,340 & 21,622 & 21,355 & 22,135 & 22,538 & 24,862 \\
\hline & & D-pond & 10,716 & 22,012 & 19,005 & 18,503 & 19,340 & 28,613 \\
\hline \multirow[t]{8}{*}{$\mathrm{Hg}$} & SHP & Pond 1 & 0.03 & NQ & NQ & NQ & NQ & NQ \\
\hline & & Pond 2 & 0.02 & NQ & NQ & NQ & NQ & NQ \\
\hline & & Pond 3 & 0.04 & NQ & NQ & NQ & NQ & NQ \\
\hline & & Pond 4 & 0.06 & NQ & NQ & NQ & NQ & NQ \\
\hline & Reference & Alamo River & 0.02 & NQ & NQ & NQ & NQ & NQ \\
\hline & & Salton Sea & 0.04 & NQ & NQ & NQ & NQ & NQ \\
\hline & & Freshwater Marsh & 0.04 & NQ & NQ & NQ & NQ & NQ \\
\hline & & D-pond & 0.01 & NQ & NQ & NQ & NQ & NQ \\
\hline \multirow[t]{8}{*}{ Mn } & SHP & Pond 1 & 809 & 986 & 1,119 & 850 & 1,079 & 870 \\
\hline & & Pond 2 & 695 & 843 & 1,066 & 870 & 1,127 & 1,065 \\
\hline & & Pond 3 & 419 & 589 & 516 & 478 & 506 & 492 \\
\hline & & Pond 4 & 397 & 617 & 474 & 378 & 382 & 357 \\
\hline & Reference & Alamo River & 396 & 458 & 493 & 459 & 396 & 423 \\
\hline & & Salton Sea & 408 & 379 & 472 & 370 & 485 & 462 \\
\hline & & Freshwater Marsh & 457 & 428 & 436 & 439 & 444 & 514 \\
\hline & & D-pond & 242 & 502 & 439 & 442 & 443 & 510 \\
\hline \multirow[t]{8}{*}{ Mo } & SHP & Pond 1 & 1.90 & 1.11 & 1.24 & 1.92 & 1.09 & 1.02 \\
\hline & & Pond 2 & 1.48 & 0.86 & 0.82 & 1.04 & 0.96 & 0.62 \\
\hline & & Pond 3 & 1.43 & 1.54 & 3.10 & 2.56 & 1.46 & 1.73 \\
\hline & & Pond 4 & 1.87 & 1.66 & 2.96 & 2.21 & 1.23 & 1.00 \\
\hline & Reference & Alamo River & 0.71 & 0.43 & 0.40 & 0.77 & 0.33 & 0.26 \\
\hline & & Salton Sea & 1.73 & 1.16 & 1.76 & 1.81 & 1.40 & 0.73 \\
\hline & & Freshwater Marsh & 0.913 & 0.807 & 0.602 & 1.03 & 0.380 & 0.204 \\
\hline & & D-pond & 0.468 & 0.428 & 0.498 & 0.680 & 0.421 & 0.023 \\
\hline \multirow[t]{8}{*}{$\mathrm{Ni}$} & SHP & Pond 1 & 12.0 & 15.9 & 14.7 & 16.0 & 13.8 & 14.4 \\
\hline & & Pond 2 & 8.8 & 10.3 & 11.4 & 11.1 & 11.9 & 13.7 \\
\hline & & Pond 3 & 13.1 & 16.3 & 15.0 & 12.9 & 13.2 & 11.8 \\
\hline & & Pond 4 & 12.7 & 16.2 & 15.2 & 12.5 & 12.0 & 10.9 \\
\hline & Reference & Alamo River & 11.6 & 12.9 & 14.1 & 13.3 & 10.9 & 12.9 \\
\hline & & Salton Sea & 13.2 & 11.5 & 13.4 & 10.2 & 13.9 & 15.4 \\
\hline & & Freshwater Marsh & 15.8 & 13.5 & 13.7 & 15.7 & 15.0 & 17.2 \\
\hline & & D-pond & 6.3 & 15.7 & 12.2 & 14.2 & 14.1 & 22.0 \\
\hline
\end{tabular}


Table 10. Arithmetic mean values for concentrations of trace elements $(\mu \mathrm{g} / \mathrm{g}$, dry weight) in sediment samples collected from saline habitat ponds (SHP) and reference sites, Ecosystem Monitoring Project, Salton Sea, California, spring 2006-fall 2008.-Continued

[ $\mathrm{n}=3$ for all sites and sampling periods, except for spring 2006 Salton Sea $(\mathrm{n}=2)$, Alamo River, Freshwater Marsh, and D-Pond $(\mathrm{n}=1)$. Element definitions are given in table 8. ND, all concentrations below limit of detection (LOD), which are provided in appendix 5. NQ, element not quantified]

\begin{tabular}{|c|c|c|c|c|c|c|c|c|}
\hline \multirow[b]{2}{*}{ Element } & \multirow[b]{2}{*}{ Group } & \multirow[b]{2}{*}{ Site } & \multicolumn{6}{|c|}{ Sampling period } \\
\hline & & & $\begin{array}{c}\text { Spring } \\
2006\end{array}$ & $\begin{array}{c}\text { Fall } \\
2006 \\
\end{array}$ & $\begin{array}{c}\text { Spring } \\
2007\end{array}$ & $\begin{array}{l}\text { Fall } \\
2007\end{array}$ & $\begin{array}{c}\text { Spring } \\
2008\end{array}$ & $\begin{array}{l}\text { Fall } \\
2008\end{array}$ \\
\hline \multirow[t]{8}{*}{$\mathrm{Pb}$} & SHP & Pond 1 & 28.4 & 33.5 & 34.8 & 34.5 & 38.0 & 39.2 \\
\hline & & Pond 2 & 37.2 & 44.9 & 48.9 & 33.9 & 41.9 & 49.1 \\
\hline & & Pond 3 & 15.0 & 15.2 & 14.7 & 8.9 & 12.4 & 10.0 \\
\hline & & Pond 4 & 14.4 & 15.1 & 14.7 & 9.3 & 11.5 & 9.4 \\
\hline & Reference & Alamo River & 14.8 & 11.4 & 13.3 & 11.6 & 13.5 & 12.5 \\
\hline & & Salton Sea & 17.6 & 8.9 & 14.4 & 8.5 & 16.4 & 17.3 \\
\hline & & Freshwater Marsh & 17.2 & 12.1 & 14.1 & 11.3 & 13.7 & 16.1 \\
\hline & & D-pond & 13.5 & 15.1 & 14.8 & 12.5 & 16.1 & 23.5 \\
\hline \multirow[t]{8}{*}{$\mathrm{Sb}$} & SHP & Pond 1 & ND & 1.51 & 0.464 & 1.88 & NQ & NQ \\
\hline & & Pond 2 & 1.09 & 2.29 & 0.645 & 1.74 & NQ & NQ \\
\hline & & Pond 3 & ND & 0.819 & ND & 0.615 & NQ & NQ \\
\hline & & Pond 4 & ND & 0.873 & ND & 0.601 & NQ & NQ \\
\hline & Reference & Alamo River & ND & 0.693 & ND & 0.634 & NQ & NQ \\
\hline & & Salton Sea & ND & 0.673 & ND & 0.697 & NQ & NQ \\
\hline & & Freshwater Marsh & ND & 0.720 & ND & 0.753 & NQ & NQ \\
\hline & & D-pond & ND & 0.750 & ND & 0.707 & NQ & NQ \\
\hline \multirow[t]{8}{*}{$\mathrm{Se}^{2}$} & SHP & Pond 1 & 1.03 & 1.38 & 2.15 & 2.32 & 2.22 & 1.68 \\
\hline & & Pond 2 & 0.94 & 1.25 & 1.37 & 1.31 & 1.61 & 1.48 \\
\hline & & Pond 3 & 1.83 & 2.99 & 3.00 & 2.06 & 2.12 & 1.73 \\
\hline & & Pond 4 & 1.67 & 2.44 & 2.35 & 1.97 & 1.92 & 1.37 \\
\hline & Reference & Alamo River & 0.614 & 0.523 & 0.640 & 0.597 & 0.540 & 0.476 \\
\hline & & Salton Sea & 1.42 & 1.66 & 2.31 & 1.45 & 2.42 & 1.67 \\
\hline & & Freshwater Marsh & 1.73 & 2.03 & 2.27 & 1.97 & 2.67 & 2.16 \\
\hline & & D-pond & 0.61 & 0.61 & 0.43 & 0.47 & 0.59 & 0.38 \\
\hline \multirow[t]{8}{*}{ Sn } & SHP & Pond 1 & 1.12 & 1.68 & 0.94 & 1.66 & ND & ND \\
\hline & & Pond 2 & 0.81 & 1.13 & 0.71 & 1.11 & ND & ND \\
\hline & & Pond 3 & 1.30 & 1.69 & 1.12 & 1.33 & ND & ND \\
\hline & & Pond 4 & 1.25 & 1.76 & 1.07 & 1.30 & ND & ND \\
\hline & Reference & Alamo River & 1.07 & 1.41 & 0.85 & 1.41 & ND & ND \\
\hline & & Salton Sea & 1.22 & 1.28 & 0.90 & 1.20 & ND & ND \\
\hline & & Freshwater Marsh & 1.54 & 1.56 & 0.94 & 1.63 & ND & ND \\
\hline & & D-pond & 0.60 & 1.57 & 0.77 & 1.39 & ND & ND \\
\hline \multirow[t]{8}{*}{$\mathrm{Tl}$} & SHP & Pond 1 & 1.13 & 1.22 & 1.76 & 1.79 & ND & ND \\
\hline & & Pond 2 & 1.44 & 2.58 & 2.34 & 2.62 & ND & ND \\
\hline & & Pond 3 & ND & 0.592 & 0.595 & 0.464 & ND & ND \\
\hline & & Pond 4 & 0.327 & 0.563 & 0.555 & 0.448 & ND & ND \\
\hline & Reference & Alamo River & 1.24 & 0.512 & 0.556 & 0.485 & ND & ND \\
\hline & & Salton Sea & 0.61 & 0.473 & 0.577 & 0.459 & ND & ND \\
\hline & & Freshwater Marsh & ND & 0.525 & 0.539 & 0.542 & ND & ND \\
\hline & & D-pond & ND & 0.547 & 0.534 & 0.498 & ND & ND \\
\hline
\end{tabular}


Table 10. Arithmetic mean values for concentrations of trace elements $(\mu \mathrm{g} / \mathrm{g}$, dry weight) in sediment samples collected from saline habitat ponds (SHP) and reference sites, Ecosystem Monitoring Project, Salton Sea, California, spring 2006-fall 2008.-Continued

[ $\mathrm{n}=3$ for all sites and sampling periods, except for spring 2006 Salton Sea $(\mathrm{n}=2)$, Alamo River, Freshwater Marsh, and D-Pond $(n=1)$. Element definitions are given in table 8. ND, all concentrations below limit of detection (LOD), which are provided in appendix 5. NQ, element not quantified]

\begin{tabular}{|c|c|c|c|c|c|c|c|c|}
\hline \multirow[b]{2}{*}{ Element } & \multirow[b]{2}{*}{ Group } & \multirow[b]{2}{*}{ Site } & \multicolumn{6}{|c|}{ Sampling period } \\
\hline & & & $\begin{array}{c}\text { Spring } \\
2006\end{array}$ & $\begin{array}{l}\text { Fall } \\
2006\end{array}$ & $\begin{array}{c}\text { Spring } \\
2007\end{array}$ & $\begin{array}{c}\text { Fall } \\
2007\end{array}$ & $\begin{array}{c}\text { Spring } \\
2008 \\
\end{array}$ & $\begin{array}{c}\text { Fall } \\
2008 \\
\end{array}$ \\
\hline \multirow[t]{8}{*}{$\mathrm{V}$} & SHP & Pond 1 & 58.2 & 73.3 & 67.6 & 71.5 & 62.5 & 61.0 \\
\hline & & Pond 2 & 44.6 & 48.9 & 55.4 & 51.1 & 54.9 & 58.6 \\
\hline & & Pond 3 & 60.9 & 71.9 & 67.3 & 55.2 & 55.5 & 47.9 \\
\hline & & Pond 4 & 58.0 & 71.7 & 67.5 & 55.4 & 53.5 & 45.8 \\
\hline & Reference & Alamo River & 51.0 & 56.7 & 59.3 & 58.3 & 47.6 & 52.3 \\
\hline & & Salton Sea & 60.7 & 51.4 & 64.0 & 45.5 & 62.5 & 66.4 \\
\hline & & Freshwater Marsh & 70.6 & 60.4 & 60.6 & 68.4 & 66.1 & 69.0 \\
\hline & & D-pond & 31.5 & 66.3 & 55.6 & 58.8 & 58.1 & 89.4 \\
\hline \multirow[t]{8}{*}{$\mathrm{Zn}$} & SHP & Pond 1 & 146 & 212 & 234 & 201 & 246 & 226 \\
\hline & & Pond 2 & 277 & 423 & 431 & 363 & 347 & 419 \\
\hline & & Pond 3 & 64.3 & 89.3 & 70.5 & 61.6 & 65.7 & 54.3 \\
\hline & & Pond 4 & 61.0 & 87.3 & 68.3 & 57.2 & 53.4 & 51.8 \\
\hline & Reference & Alamo River & 52.5 & 60.4 & 61.9 & 60.1 & 48.4 & 57.2 \\
\hline & & Salton Sea & 60.9 & 55.1 & 64.2 & 53.7 & 69.2 & 73.2 \\
\hline & & Freshwater Marsh & 72.5 & 61.3 & 63.7 & 70.5 & 66.6 & 73.5 \\
\hline & & D-pond & 29.9 & 66.0 & 56.3 & 59.1 & 56.8 & 86.1 \\
\hline
\end{tabular}

\footnotetext{
${ }^{1}$ D-pond was dry in fall 2008, Salton Sea National Wildlife Refuge Hazard Pond sampled in its place.

${ }^{2}$ Spring 2006 values are conservative estimates using the upper 95\% confidence limits from the corrective equation derived from the regression of Se determined from ICP-OES against Se determined from HGAA-FIAS (adjusted Se $\left.=\exp -0.51+0.66^{\text {Se ICP-OES }}\right) ; r^{2}=0.68$ )
} 
Table 11. Arithmetic mean values for concentrations of DDT compounds ( $\mu \mathrm{g} / \mathrm{g}$, dry weight) in sediment samples collected from saline habitat ponds (SHP) and reference sites, Ecosystem Monitoring Project, Salton Sea, California, spring 2006-fall 2008.

[ $n=3$ for all sites and sampling periods, except for spring 2006 Alamo River $(n=1)$, Freshwater Marsh $(n=2)$, and Salton Sea $(n=2)$. Sampling period: Fall 2006 was not sampled. ND, all concentrations were below limit of detection (LOD), which are provided in appendix 6]

\begin{tabular}{|c|c|c|c|c|c|c|c|}
\hline \multirow[b]{2}{*}{ Compound } & \multirow[b]{2}{*}{ Group } & \multirow[b]{2}{*}{ Site } & \multicolumn{5}{|c|}{ Sampling period } \\
\hline & & & $\begin{array}{c}\text { Spring } \\
2006\end{array}$ & $\begin{array}{c}\text { Spring } \\
2007\end{array}$ & $\begin{array}{l}\text { Fall } \\
2007\end{array}$ & $\begin{array}{c}\text { Spring } \\
2008\end{array}$ & $\begin{array}{l}\text { Fall } \\
2008\end{array}$ \\
\hline \multirow[t]{8}{*}{$p, p^{\prime} \mathrm{DDD}$} & SHP & Pond 1 & ND & ND & ND & ND & ND \\
\hline & & Pond 2 & ND & ND & ND & ND & ND \\
\hline & & Pond 3 & ND & ND & ND & ND & ND \\
\hline & & Pond 4 & ND & ND & ND & ND & ND \\
\hline & Reference & Alamo River & ND & ND & ND & ND & ND \\
\hline & & Salton Sea & ND & ND & ND & ND & 0.002 \\
\hline & & Freshwater Marsh & ND & ND & ND & ND & 0.001 \\
\hline & & D-pond ${ }^{1}$ & ND & ND & ND & ND & ND \\
\hline \multirow[t]{8}{*}{$p, p^{\prime} \mathrm{DDE}$} & SHP & Pond 1 & 0.008 & 0.008 & 0.024 & 0.012 & 0.012 \\
\hline & & Pond 2 & 0.005 & 0.007 & 0.011 & 0.009 & 0.009 \\
\hline & & Pond 3 & 0.021 & 0.048 & 0.041 & 0.026 & 0.030 \\
\hline & & Pond 4 & 0.016 & 0.009 & 0.013 & 0.007 & 0.004 \\
\hline & Reference & Alamo River & 0.047 & 0.054 & 0.041 & 0.056 & 0.045 \\
\hline & & Salton Sea & 0.022 & 0.031 & 0.028 & 0.015 & 0.041 \\
\hline & & Freshwater Marsh & 0.060 & 0.062 & 0.098 & 0.090 & 0.095 \\
\hline & & D-pond & 0.002 & 0.006 & 0.004 & 0.005 & 0.004 \\
\hline \multirow[t]{8}{*}{$p, p^{\prime} \mathrm{DDT}$} & SHP & Pond 1 & ND & ND & ND & ND & ND \\
\hline & & Pond 2 & ND & ND & ND & ND & ND \\
\hline & & Pond 3 & ND & ND & ND & ND & ND \\
\hline & & Pond 4 & ND & ND & ND & ND & ND \\
\hline & Reference & Alamo River & ND & ND & ND & ND & 0.002 \\
\hline & & Salton Sea & ND & ND & ND & ND & 0.002 \\
\hline & & Freshwater Marsh & ND & ND & ND & ND & 0.003 \\
\hline & & D-pond & ND & ND & ND & ND & ND \\
\hline \multirow[t]{8}{*}{$o, p^{\prime} \mathrm{DDD}$} & SHP & Pond 1 & ND & ND & ND & ND & ND \\
\hline & & Pond 2 & ND & ND & ND & ND & ND \\
\hline & & Pond 3 & ND & ND & ND & ND & ND \\
\hline & & Pond 4 & ND & ND & ND & ND & ND \\
\hline & Reference & Alamo River & ND & ND & ND & ND & ND \\
\hline & & Salton Sea & ND & ND & ND & ND & ND \\
\hline & & Freshwater Marsh & ND & ND & ND & ND & ND \\
\hline & & D-pond & ND & ND & ND & ND & ND \\
\hline \multirow[t]{8}{*}{$o, p^{\prime} \mathrm{DDE}$} & SHP & Pond 1 & ND & ND & ND & ND & ND \\
\hline & & Pond 2 & ND & ND & ND & ND & 0.001 \\
\hline & & Pond 3 & ND & ND & ND & ND & ND \\
\hline & & Pond 4 & ND & ND & ND & ND & ND \\
\hline & Reference & Alamo River & ND & ND & ND & ND & 0.002 \\
\hline & & Salton Sea & ND & ND & ND & ND & 0.004 \\
\hline & & Freshwater Marsh & ND & ND & ND & 0.006 & 0.005 \\
\hline & & D-pond & ND & ND & ND & ND & ND \\
\hline
\end{tabular}


Table 11. Arithmetic mean values for concentrations of DDT compounds ( $\mu \mathrm{g} / \mathrm{g}$, dry weight) in sediment samples collected from saline habitat ponds (SHP) and reference sites, Ecosystem Monitoring Project, Salton Sea, California, spring 2006-fall 2008.

[n = 3 for all sites and sampling periods, except for spring 2006 Alamo River $(n=1)$, Freshwater Marsh $(n=2)$, and Salton Sea $(n=2)$. Sampling period: Fall 2006 was not sampled. ND, all concentrations were below limit of detection (LOD), which are provided in appendix 6]

\begin{tabular}{|c|c|c|c|c|c|c|c|}
\hline \multirow[b]{2}{*}{ Compound } & \multirow[b]{2}{*}{ Group } & \multirow[b]{2}{*}{ Site } & \multicolumn{5}{|c|}{ Sampling period } \\
\hline & & & $\begin{array}{c}\text { Spring } \\
2006\end{array}$ & $\begin{array}{c}\text { Spring } \\
2007\end{array}$ & $\begin{array}{l}\text { Fall } \\
2007\end{array}$ & $\begin{array}{c}\text { Spring } \\
2008\end{array}$ & $\begin{array}{c}\text { Fall } \\
2008\end{array}$ \\
\hline \multirow[t]{8}{*}{$o, p^{\prime} \mathrm{DDT}$} & SHP & Pond 1 & ND & ND & ND & ND & ND \\
\hline & & Pond 2 & $\mathrm{ND}$ & ND & ND & ND & ND \\
\hline & & Pond 3 & ND & ND & ND & ND & ND \\
\hline & & Pond 4 & ND & ND & ND & ND & ND \\
\hline & Reference & Alamo River & ND & ND & ND & ND & ND \\
\hline & & Salton Sea & ND & ND & ND & ND & ND \\
\hline & & Freshwater Marsh & $\mathrm{ND}$ & ND & ND & ND & ND \\
\hline & & D-pond & ND & ND & ND & ND & ND \\
\hline
\end{tabular}

${ }^{1}$ D-pond was dry in fall 2008, Salton Sea National Wildlife Refuge Hazard Pond sampled in its place. 
Table 12. Arithmetic mean concentrations of trace elements ( $\mu \mathrm{g} / \mathrm{g}$, dry weight) in invertebrate samples collected from saline habitat ponds (SHP) and reference sites, Ecosystem Monitoring Project, Salton Sea, California, fall 2006-fall 2008.

[ $\mathrm{n}=3$ for all sites and sampling periods, except for fall 2006 Salton Sea $(\mathrm{n}=2)$. Element definitions are given in table 8. ND, all concentrations were below limit of detection (LOD), which are provided in appendix 7. NQ, element not quantified]

\begin{tabular}{|c|c|c|c|c|c|c|c|}
\hline \multirow[b]{2}{*}{ Element } & \multirow[b]{2}{*}{ Group } & \multirow[b]{2}{*}{ Site } & \multicolumn{5}{|c|}{ Sampling period } \\
\hline & & & $\begin{array}{l}\text { Fall } \\
2006\end{array}$ & $\begin{array}{c}\text { Spring } \\
2007\end{array}$ & $\begin{array}{l}\text { Fall } \\
2007\end{array}$ & $\begin{array}{c}\text { Spring } \\
2008\end{array}$ & $\begin{array}{l}\text { Fall } \\
2008\end{array}$ \\
\hline \multirow[t]{7}{*}{ Ag } & SHP & Pond 1 & 0.427 & 0.180 & 0.290 & 0.356 & 0.226 \\
\hline & & Pond 2 & 0.574 & 0.245 & 0.222 & 0.415 & 0.269 \\
\hline & & Pond 3 & 0.457 & 0.451 & 0.329 & 0.708 & 0.593 \\
\hline & & Pond $4^{1}$ & 2.15 & 0.597 & 0.479 & 0.287 & 0.097 \\
\hline & Reference & Salton Sea & 0.113 & 0.098 & 0.129 & 0.075 & 0.190 \\
\hline & & Freshwater Marsh & 0.099 & 0.087 & 0.117 & 0.125 & 0.184 \\
\hline & & D-pond ${ }^{2}$ & 0.073 & 0.075 & 0.128 & 0.107 & 0.330 \\
\hline \multirow[t]{7}{*}{$\mathrm{Al}$} & SHP & Pond 1 & 412 & 535 & 820 & 668 & 381 \\
\hline & & Pond 2 & 570 & 1,243 & 1,458 & 325 & 438 \\
\hline & & Pond 3 & 385 & 1,152 & 580 & 134 & 60 \\
\hline & & Pond 4 & 615 & 590 & 901 & 1,380 & 321 \\
\hline & Reference & Salton Sea & 51.4 & 899 & 85 & 323 & 783 \\
\hline & & Freshwater Marsh & 192 & 707 & 2,654 & 296 & 252 \\
\hline & & D-pond & 605 & 441 & 341 & 347 & 3,701 \\
\hline \multirow[t]{7}{*}{ As } & SHP & Pond 1 & ND & ND & 1.18 & ND & 2.54 \\
\hline & & Pond 2 & ND & ND & 1.35 & ND & 2.23 \\
\hline & & Pond 3 & ND & ND & 1.11 & ND & 4.23 \\
\hline & & Pond 4 & ND & $N D$ & 0.856 & $N D$ & 16.0 \\
\hline & Reference & Salton Sea & ND & ND & 0.893 & ND & 1.34 \\
\hline & & Freshwater Marsh & ND & ND & 1.60 & ND & ND \\
\hline & & D-pond & ND & ND & 0.394 & ND & 3.03 \\
\hline \multirow[t]{7}{*}{ B } & SHP & Pond 1 & 6.12 & 22.2 & 5.91 & 4.13 & 19.2 \\
\hline & & Pond 2 & 18.3 & 32.9 & 13.6 & 17.9 & 27.1 \\
\hline & & Pond 3 & 29.0 & 98.0 & 42.1 & 43.8 & 62.8 \\
\hline & & Pond 4 & 77.0 & 72.5 & 68.5 & 245 & 213 \\
\hline & Reference & Salton Sea & 8.96 & 18.5 & 14.5 & 3.35 & 5.85 \\
\hline & & Freshwater Marsh & 2.80 & 3.40 & 4.94 & 2.92 & 2.07 \\
\hline & & D-pond & 5.12 & 1.98 & 1.65 & 0.37 & 5.09 \\
\hline \multirow[t]{7}{*}{$\mathrm{Ba}$} & SHP & Pond 1 & 5.71 & 7.41 & 9.84 & 12.7 & 8.29 \\
\hline & & Pond 2 & 6.12 & 12.1 & 14.9 & 5.35 & 11.1 \\
\hline & & Pond 3 & 4.08 & 10.0 & 9.60 & 2.1 & 6.32 \\
\hline & & Pond 4 & 7.22 & 7.88 & 60.3 & 19.0 & 118 \\
\hline & Reference & Salton Sea & 1.45 & 8.40 & 5.02 & 5.86 & 10.4 \\
\hline & & Freshwater Marsh & 46.6 & 16.2 & 35.1 & 8.25 & 11.6 \\
\hline & & D-pond & 16.8 & 6.60 & 7.80 & 4.50 & 32.5 \\
\hline \multirow[t]{7}{*}{$\mathrm{Be}$} & SHP & Pond 1 & 0.022 & 0.037 & 0.071 & 0.008 & 0.025 \\
\hline & & Pond 2 & 0.026 & 0.059 & 0.105 & 0.007 & 0.034 \\
\hline & & Pond 3 & 0.021 & 0.060 & 0.065 & 0.004 & 0.026 \\
\hline & & Pond 4 & 0.036 & 0.046 & 0.106 & 0.101 & 0.038 \\
\hline & Reference & Salton Sea & 0.004 & 0.050 & 0.036 & 0.004 & 0.044 \\
\hline & & Freshwater Marsh & 0.009 & 0.037 & 0.143 & ND & 0.021 \\
\hline & & D-pond & 0.029 & 0.029 & 0.043 & ND & 0.147 \\
\hline
\end{tabular}


Table 12. Arithmetic mean concentrations of trace elements ( $\mu \mathrm{g} / \mathrm{g}$, dry weight) in invertebrate samples collected from saline habitat ponds (SHP) and reference sites, Ecosystem Monitoring Project, Salton Sea, California, fall 2006-fall 2008.-Continued

[ $\mathrm{n}=3$ for all sites and sampling periods, except for fall 2006 Salton Sea $(\mathrm{n}=2)$. Element definitions are given in table 8. ND, all concentrations were below limit of detection (LOD), which are provided in appendix 7. NQ, element not quantified]

\begin{tabular}{|c|c|c|c|c|c|c|c|}
\hline \multirow[b]{2}{*}{ Element } & \multirow[b]{2}{*}{ Group } & \multirow[b]{2}{*}{ Site } & \multicolumn{5}{|c|}{ Sampling period } \\
\hline & & & $\begin{array}{c}\text { Fall } \\
2006\end{array}$ & $\begin{array}{c}\text { Spring } \\
2007\end{array}$ & $\begin{array}{l}\text { Fall } \\
2007\end{array}$ & $\begin{array}{c}\text { Spring } \\
2008\end{array}$ & $\begin{array}{c}\text { Fall } \\
2008\end{array}$ \\
\hline \multirow[t]{7}{*}{$\mathrm{Cd}$} & SHP & Pond 1 & 0.147 & 0.118 & 0.179 & 0.107 & 0.091 \\
\hline & & Pond 2 & 0.131 & 0.130 & 0.074 & 0.126 & 0.052 \\
\hline & & Pond 3 & 0.386 & 0.551 & 0.220 & 0.227 & 0.380 \\
\hline & & Pond 4 & 0.721 & 0.551 & 0.260 & 0.373 & 0.116 \\
\hline & Reference & Salton Sea & 0.106 & 0.168 & 0.187 & 0.125 & 0.209 \\
\hline & & Freshwater Marsh & 0.116 & 0.155 & 0.195 & 0.201 & 0.244 \\
\hline & & D-pond & 0.083 & 0.101 & 0.109 & 0.116 & 0.977 \\
\hline \multirow[t]{7}{*}{ Co } & SHP & Pond 1 & 0.778 & 0.308 & 0.268 & 0.271 & 0.416 \\
\hline & & Pond 2 & 0.471 & 0.433 & 0.402 & 0.217 & 0.291 \\
\hline & & Pond 3 & 0.455 & 0.462 & 0.298 & 0.178 & 0.315 \\
\hline & & Pond 4 & 1.666 & 0.527 & 0.193 & 0.535 & 0.114 \\
\hline & Reference & Salton Sea & 0.196 & 0.386 & 0.259 & 0.286 & 0.340 \\
\hline & & Freshwater Marsh & 0.270 & 0.408 & 0.692 & 0.215 & 0.191 \\
\hline & & D-pond & 0.551 & 0.486 & 0.346 & 0.307 & 1.022 \\
\hline \multirow[t]{7}{*}{$\mathrm{Cr}$} & SHP & Pond 1 & 0.759 & 0.784 & 0.906 & 0.964 & 0.507 \\
\hline & & Pond 2 & 0.824 & 1.34 & 1.36 & 0.469 & 0.495 \\
\hline & & Pond 3 & 0.644 & 1.23 & 0.727 & 0.384 & 0.166 \\
\hline & & Pond 4 & 0.914 & 1.27 & 1.25 & 1.13 & $N D$ \\
\hline & Reference & Salton Sea & 0.357 & 1.10 & 0.306 & 0.501 & 1.08 \\
\hline & & Freshwater Marsh & 0.459 & 1.03 & 2.63 & 0.522 & 0.379 \\
\hline & & D-pond & 0.925 & 0.603 & 0.549 & 0.509 & 3.15 \\
\hline \multirow[t]{7}{*}{$\mathrm{Cu}$} & SHP & Pond 1 & 43.93 & 21.57 & 23.10 & 52.33 & 13.63 \\
\hline & & Pond 2 & 35.90 & 36.63 & 13.43 & 43.69 & 12.97 \\
\hline & & Pond 3 & 31.17 & 33.06 & 26.03 & 53.49 & 40.73 \\
\hline & & Pond 4 & 31.40 & 9.23 & 9.21 & 11.35 & 9.78 \\
\hline & Reference & Salton Sea & 15.04 & 14.07 & 13.90 & 11.75 & 18.93 \\
\hline & & Freshwater Marsh & 11.10 & 13.09 & 15.17 & 23.00 & 18.60 \\
\hline & & D-pond & 8.15 & 11.13 & 17.97 & 13.78 & 29.20 \\
\hline \multirow[t]{7}{*}{$\mathrm{Fe}$} & SHP & Pond 1 & 468 & 518 & 698 & 731 & 506 \\
\hline & & Pond 2 & 674 & 936 & 1,390 & 414 & 665 \\
\hline & & Pond 3 & 463 & 968 & 513 & 246 & 202 \\
\hline & & Pond 4 & 777 & 1,936 & 846 & 1,499 & 286 \\
\hline & Reference & Salton Sea & 129 & 636 & 184 & 333 & 604 \\
\hline & & Freshwater Marsh & 238 & 573 & 1,938 & 371 & 262 \\
\hline & & D-pond & 482 & 357 & 311 & 314 & 2,102 \\
\hline \multirow[t]{7}{*}{ Mn } & SHP & Pond 1 & 31.0 & 46.0 & 71.5 & 42.2 & 37.3 \\
\hline & & Pond 2 & 112 & 74.9 & 120 & 40.9 & 155 \\
\hline & & Pond 3 & 65.5 & 85.4 & 51.0 & 17.0 & 444 \\
\hline & & Pond 4 & 127 & 1,246 & 2,101 & 1,986 & 2,603 \\
\hline & Reference & Salton Sea & 9.03 & 25.1 & 30.84 & 16.5 & 25.3 \\
\hline & & Freshwater Marsh & 11.2 & 19.2 & 46.3 & 14.0 & 10.9 \\
\hline & & D-pond & 17.4 & 18.2 & 18.7 & 16.6 & 76.5 \\
\hline
\end{tabular}


Table 12. Arithmetic mean concentrations of trace elements ( $\mu \mathrm{g} / \mathrm{g}$, dry weight) in invertebrate samples collected from saline habitat ponds (SHP) and reference sites, Ecosystem Monitoring Project, Salton Sea, California, fall 2006-fall 2008.-Continued

[ $\mathrm{n}=3$ for all sites and sampling periods, except for fall 2006 Salton Sea $(n=2)$. Element definitions are given in table 8. ND, all concentrations were below limit of detection (LOD), which are provided in appendix 7. NQ, element not quantified]

\begin{tabular}{|c|c|c|c|c|c|c|c|}
\hline \multirow[b]{2}{*}{ Element } & \multirow[b]{2}{*}{ Group } & \multirow[b]{2}{*}{ Site } & \multicolumn{5}{|c|}{ Sampling period } \\
\hline & & & Fall 2006 & Spring 2007 & Fall 2007 & Spring 2008 & Fall 2008 \\
\hline \multirow[t]{7}{*}{ Mo } & SHP & Pond 1 & 0.756 & 0.663 & 0.735 & 0.710 & 0.799 \\
\hline & & Pond 2 & 0.884 & 0.802 & 0.653 & 0.695 & 0.626 \\
\hline & & Pond 3 & 0.642 & 0.755 & 0.615 & 0.502 & 0.564 \\
\hline & & Pond 4 & 0.862 & 0.506 & $N D$ & 0.266 & $N D$ \\
\hline & Reference & Salton Sea & 0.603 & 0.657 & 0.504 & 0.677 & 0.981 \\
\hline & & Freshwater Marsh & 0.760 & 0.737 & 0.763 & 0.825 & 0.739 \\
\hline & & D-pond & 0.687 & 0.716 & 0.825 & 0.605 & 0.908 \\
\hline \multirow[t]{7}{*}{$\mathrm{Ni}$} & SHP & Pond 1 & 0.574 & 0.416 & 0.782 & 0.691 & 0.472 \\
\hline & & Pond 2 & 1.064 & 0.698 & 0.846 & 0.351 & 0.586 \\
\hline & & Pond 3 & 0.567 & 0.817 & 0.575 & 0.278 & 0.451 \\
\hline & & Pond 4 & 0.610 & 0.382 & 0.586 & 0.940 & 0.254 \\
\hline & Reference & Salton Sea & 0.261 & 0.578 & 0.310 & 0.350 & 0.924 \\
\hline & & Freshwater Marsh & 0.369 & 0.592 & 1.630 & 0.347 & 0.351 \\
\hline & & D-pond & 0.613 & 0.397 & 0.292 & 0.298 & 1.99 \\
\hline \multirow[t]{7}{*}{$\mathrm{Pb}$} & SHP & Pond 1 & 1.62 & 1.11 & 0.916 & 1.95 & 0.947 \\
\hline & & Pond 2 & 1.42 & 1.36 & 1.24 & 0.869 & 0.900 \\
\hline & & Pond 3 & 0.648 & 0.938 & 0.410 & 0.273 & 0.327 \\
\hline & & Pond 4 & 1.41 & 1.46 & 0.664 & 3.78 & 0.738 \\
\hline & Reference & Salton Sea & 0.222 & 0.731 & 0.454 & 2.45 & 0.342 \\
\hline & & Freshwater Marsh & 0.320 & 0.730 & 1.09 & 0.321 & 0.231 \\
\hline & & D-pond & 0.473 & 0.729 & 0.273 & 0.86 & 2.28 \\
\hline \multirow[t]{7}{*}{$\mathrm{Sb}$} & SHP & Pond 1 & 0.193 & ND & ND & ND & ND \\
\hline & & Pond 2 & 0.321 & 0.119 & ND & ND & ND \\
\hline & & Pond 3 & 0.116 & ND & ND & ND & ND \\
\hline & & Pond 4 & 0.114 & $N D$ & $N D$ & 0.11 & $N D$ \\
\hline & Reference & Salton Sea & ND & ND & ND & ND & ND \\
\hline & & Freshwater Marsh & ND & ND & ND & ND & ND \\
\hline & & D-pond & ND & 0.135 & ND & ND & ND \\
\hline \multirow[t]{7}{*}{ Se } & SHP & Pond 1 & 6.69 & 5.10 & 2.28 & 7.36 & 4.59 \\
\hline & & Pond 2 & 8.50 & 5.32 & 2.22 & 5.63 & 4.09 \\
\hline & & Pond 3 & 6.76 & 4.58 & 5.34 & 4.61 & 2.77 \\
\hline & & Pond 4 & 3.51 & 2.56 & 2.30 & 2.16 & 2.84 \\
\hline & Reference & Salton Sea & 2.51 & 2.37 & 3.03 & 3.64 & 2.97 \\
\hline & & Freshwater Marsh & 2.05 & 2.60 & 2.74 & 2.83 & 2.30 \\
\hline & & D-pond & 1.42 & 0.916 & 1.98 & 1.37 & 2.31 \\
\hline \multirow[t]{7}{*}{ Sn } & SHP & Pond 1 & 0.421 & 0.533 & 0.236 & NQ & NQ \\
\hline & & Pond 2 & 0.829 & 0.287 & 0.181 & NQ & NQ \\
\hline & & Pond 3 & 0.245 & 0.590 & 0.272 & NQ & NQ \\
\hline & & Pond 4 & 0.400 & 0.116 & 0.295 & $N Q$ & $N Q$ \\
\hline & Reference & Salton Sea & 0.492 & 0.178 & 0.349 & NQ & NQ \\
\hline & & Freshwater Marsh & 0.209 & 0.297 & 0.634 & NQ & NQ \\
\hline & & D-pond & 0.770 & 0.231 & 0.195 & NQ & NQ \\
\hline
\end{tabular}


Table 12. Arithmetic mean concentrations of trace elements ( $\mu \mathrm{g} / \mathrm{g}$, dry weight) in invertebrate samples collected from saline habitat ponds (SHP) and reference sites, Ecosystem Monitoring Project, Salton Sea, California, fall 2006-fall 2008.-Continued

[ $\mathrm{n}=3$ for all sites and sampling periods, except for fall 2006 Salton Sea $(\mathrm{n}=2)$. Element definitions are given in table 8. ND, all concentrations were below limit of detection (LOD), which are provided in appendix 7. NQ, element not quantified]

\begin{tabular}{|c|c|c|c|c|c|c|c|}
\hline \multirow[b]{2}{*}{ Element } & \multirow[b]{2}{*}{ Group } & \multirow[b]{2}{*}{ Site } & \multicolumn{5}{|c|}{ Sampling period } \\
\hline & & & Fall 2006 & Spring 2007 & Fall 2007 & Spring 2008 & Fall 2008 \\
\hline \multirow[t]{7}{*}{$\mathrm{Tl}$} & SHP & Pond 1 & ND & ND & 0.025 & ND & ND \\
\hline & & Pond 2 & ND & ND & 0.131 & ND & ND \\
\hline & & Pond 3 & ND & ND & 0.009 & ND & ND \\
\hline & & Pond 4 & ND & $N D$ & 0.019 & $N D$ & $N D$ \\
\hline & Reference & Salton Sea & ND & 0.203 & 0.017 & ND & ND \\
\hline & & Freshwater Marsh & ND & ND & 0.043 & ND & ND \\
\hline & & D-pond & ND & 0.154 & 0.007 & ND & ND \\
\hline \multirow[t]{7}{*}{$\mathrm{V}$} & SHP & Pond 1 & 0.855 & 0.958 & 1.47 & 1.31 & 0.816 \\
\hline & & Pond 2 & 1.16 & 2.03 & 2.83 & 0.608 & 0.759 \\
\hline & & Pond 3 & 0.77 & 1.98 & 1.03 & 0.191 & ND \\
\hline & & Pond 4 & 1.54 & 1.86 & 1.38 & 3.30 & 0.201 \\
\hline & Reference & Salton Sea & 0.082 & 1.50 & 0.224 & 0.625 & 1.44 \\
\hline & & Freshwater Marsh & 0.372 & 1.53 & 5.28 & 0.756 & 0.50 \\
\hline & & D-pond & 1.17 & 0.755 & 0.62 & 0.595 & 7.10 \\
\hline \multirow[t]{7}{*}{$\mathrm{Zn}$} & SHP & Pond 1 & 401 & 152 & 207 & 204 & 192 \\
\hline & & Pond 2 & 345 & 315 & 167 & 312 & 186 \\
\hline & & Pond 3 & 227 & 141 & 186 & 233 & 204 \\
\hline & & Pond 4 & 302 & 46.0 & 44.8 & 59.9 & 33.5 \\
\hline & Reference & Salton Sea & 118 & 127 & 181 & 184 & 132 \\
\hline & & Freshwater Marsh & 114 & 163 & 173 & 195 & 150 \\
\hline & & D-pond & 70 & 127 & 162 & 130 & 119 \\
\hline \multirow{7}{*}{$\begin{array}{l}\% \text { dry } \\
\text { weight }\end{array}$} & SHP & Pond 1 & 17.9 & 19.9 & 12.9 & 17.7 & 18.6 \\
\hline & & Pond 2 & 14.4 & 20.8 & 13.1 & 19.3 & 16.3 \\
\hline & & Pond 3 & 18.2 & 18.7 & 12.1 & 23.3 & 16.0 \\
\hline & & Pond 4 & 17.0 & 14.6 & 19.2 & 18.9 & 29.2 \\
\hline & Reference & Salton Sea & 24.7 & 16.3 & 19.9 & 16.1 & 16.9 \\
\hline & & Freshwater Marsh & 17.0 & 13.2 & 11.9 & 19.1 & 20.0 \\
\hline & & D-pond & 32.8 & 14.8 & 15.4 & 17.2 & 19.7 \\
\hline
\end{tabular}

${ }^{1}$ Ephydra sp. (brine fly larvae) from Pond 4 after fall 2006 (highlighted by italics), Corixidae (water boatmen) from all other sites and sampling periods.

${ }^{2}$ D-pond was dry in fall 2008, Salton Sea National Wildlife Refuge Hazard Pond sampled in its place. No invertebrates were available from Alamo River sites throughout the study. 
Table 13. Arithmetic mean concentrations of DDT compounds ( $\mu \mathrm{g} / \mathrm{g}$, wet weight) in invertebrate samples collected from saline habitat ponds (SHP) and reference sites, Ecosystem Monitoring Project, Salton Sea, California, fall 2006-fall 2008.

[ $\mathrm{n}=3$ for all sites and sampling periods, except for fall 2006 Salton Sea $(\mathrm{n}=2)$. No invertebrates were available from Alamo River sites throughout the study. ND, all concentrations were below limit of detection (LOD), which are provided in appendix $8 . \%$, percent]

\begin{tabular}{|c|c|c|c|c|c|c|c|}
\hline \multirow[b]{2}{*}{ Compound } & \multirow[b]{2}{*}{ Group } & \multirow[b]{2}{*}{ Site } & \multicolumn{5}{|c|}{ Sampling period } \\
\hline & & & $\begin{array}{l}\text { Fall } \\
2006\end{array}$ & $\begin{array}{c}\text { Spring } \\
2007\end{array}$ & $\begin{array}{c}\text { Fall } \\
2007\end{array}$ & $\begin{array}{c}\text { Spring } \\
2008 \\
\end{array}$ & $\begin{array}{c}\text { Fall } \\
2008\end{array}$ \\
\hline \multirow{7}{*}{$p, p^{\prime} \mathrm{DDD}$} & SHP & Pond 1 & ND & ND & ND & ND & ND \\
\hline & & Pond 2 & ND & ND & ND & ND & ND \\
\hline & & Pond 3 & ND & ND & ND & ND & ND \\
\hline & & Pond $4^{1}$ & ND & $N D$ & $N D$ & $N D$ & $N D$ \\
\hline & Reference & Salton Sea & ND & ND & ND & ND & ND \\
\hline & & Freshwater Marsh & ND & ND & ND & ND & ND \\
\hline & & D-pond ${ }^{2}$ & ND & ND & ND & ND & ND \\
\hline \multirow[t]{7}{*}{$p, p^{\prime} \mathrm{DDE}$} & SHP & Pond 1 & 0.010 & 0.015 & 0.009 & 0.051 & 0.010 \\
\hline & & Pond 2 & 0.008 & 0.018 & 0.013 & 0.083 & 0.007 \\
\hline & & Pond 3 & 0.012 & 0.008 & 0.008 & 0.081 & ND \\
\hline & & Pond 4 & 0.005 & 0.016 & 0.012 & 0.034 & $N D$ \\
\hline & Reference & Salton Sea & 0.013 & 0.013 & 0.010 & 0.044 & 0.019 \\
\hline & & Freshwater Marsh & 0.033 & 0.043 & 0.030 & 0.150 & 0.026 \\
\hline & & D-pond & 0.012 & 0.007 & 0.002 & 0.004 & 0.021 \\
\hline \multirow[t]{7}{*}{$p, p^{\prime} \mathrm{DDT}$} & SHP & Pond 1 & ND & ND & ND & ND & ND \\
\hline & & Pond 2 & ND & ND & ND & ND & ND \\
\hline & & Pond 3 & ND & ND & ND & ND & ND \\
\hline & & Pond 4 & ND & $N D$ & $N D$ & $N D$ & $N D$ \\
\hline & Reference & Salton Sea & ND & ND & ND & ND & ND \\
\hline & & Freshwater Marsh & ND & ND & ND & ND & ND \\
\hline & & D-pond & ND & ND & ND & ND & ND \\
\hline \multirow[t]{7}{*}{$o, p^{\prime} \mathrm{DDD}$} & SHP & Pond 1 & ND & ND & ND & ND & ND \\
\hline & & Pond 2 & ND & ND & ND & ND & ND \\
\hline & & Pond 3 & ND & ND & ND & ND & ND \\
\hline & & Pond 4 & ND & $N D$ & $N D$ & $N D$ & $N D$ \\
\hline & Reference & Salton Sea & ND & ND & ND & ND & ND \\
\hline & & Freshwater Marsh & ND & ND & ND & ND & ND \\
\hline & & D-pond & ND & ND & ND & ND & ND \\
\hline \multirow[t]{7}{*}{$o, p^{\prime} \mathrm{DDE}$} & SHP & Pond 1 & ND & ND & ND & ND & ND \\
\hline & & Pond 2 & ND & ND & ND & ND & ND \\
\hline & & Pond 3 & ND & ND & ND & ND & ND \\
\hline & & Pond 4 & ND & $N D$ & $N D$ & $N D$ & $N D$ \\
\hline & Reference & Salton Sea & ND & ND & 0.001 & ND & ND \\
\hline & & Freshwater Marsh & ND & ND & ND & ND & ND \\
\hline & & D-pond & ND & ND & ND & ND & ND \\
\hline
\end{tabular}


Table 13. Arithmetic mean concentrations of DDT compounds ( $\mu \mathrm{g} / \mathrm{g}$, wet weight) in invertebrate samples collected from saline habitat ponds (SHP) and reference sites, Ecosystem Monitoring Project, Salton Sea, California, fall 2006-fall 2008.-Continued

[ $\mathrm{n}=3$ for all sites and sampling periods, except for fall 2006 Salton Sea $(n=2)$. No invertebrates were available from Alamo River sites throughout the study. ND, all concentrations were below limit of detection (LOD), which are provided in appendix $8 . \%$, percent]

\begin{tabular}{|c|c|c|c|c|c|c|c|}
\hline \multirow[b]{2}{*}{ Compound } & \multirow[b]{2}{*}{ Group } & \multirow[b]{2}{*}{ Site } & \multicolumn{5}{|c|}{ Sampling period } \\
\hline & & & $\begin{array}{c}\text { Fall } \\
2006\end{array}$ & $\begin{array}{c}\text { Spring } \\
2007\end{array}$ & $\begin{array}{c}\text { Fall } \\
2007\end{array}$ & $\begin{array}{c}\text { Spring } \\
2008\end{array}$ & $\begin{array}{c}\text { Fall } \\
2008\end{array}$ \\
\hline \multirow[t]{7}{*}{$o, p^{\prime} \mathrm{DDT}$} & SHP & Pond 1 & ND & ND & ND & ND & ND \\
\hline & & Pond 2 & ND & ND & ND & ND & ND \\
\hline & & Pond 3 & ND & ND & ND & ND & ND \\
\hline & & Pond 4 & ND & $N D$ & $N D$ & $N D$ & $N D$ \\
\hline & Reference & Salton Sea & ND & ND & ND & ND & ND \\
\hline & & Freshwater Marsh & ND & ND & ND & ND & ND \\
\hline & & D-pond & ND & ND & ND & ND & ND \\
\hline \multirow[t]{7}{*}{ \% Lipid } & SHP & Pond 1 & 0.33 & 0.88 & 0.68 & 1.41 & 0.52 \\
\hline & & Pond 2 & 0.30 & 0.62 & 1.04 & 1.95 & 0.36 \\
\hline & & Pond 3 & 0.38 & 0.46 & 0.75 & 1.74 & 0.35 \\
\hline & & Pond 4 & 0.42 & 1.17 & 1.41 & 2.73 & 0.50 \\
\hline & Reference & Salton Sea & 1.13 & 0.68 & 0.99 & 1.28 & 0.51 \\
\hline & & Freshwater Marsh & 0.80 & 0.91 & 0.96 & 1.92 & 0.74 \\
\hline & & D-pond & 0.92 & 0.67 & 0.69 & 1.53 & 1.56 \\
\hline \multirow[t]{7}{*}{ \% Moisture } & SHP & Pond 1 & 82.8 & 80.5 & 89.5 & 93.2 & 88.4 \\
\hline & & Pond 2 & 83.5 & 78.5 & 86.0 & 88.4 & 94.5 \\
\hline & & Pond 3 & 81.5 & 82.4 & 88.3 & 84.3 & 88.9 \\
\hline & & Pond 4 & 82.1 & 89.7 & 82.0 & 86.9 & 82.1 \\
\hline & Reference & Salton Sea & 77.5 & 86.5 & 80.5 & 91.5 & 87.2 \\
\hline & & Freshwater Marsh & 84.7 & 85.0 & 87.0 & 87.9 & 85.1 \\
\hline & & D-pond & 82.0 & 87.3 & 84.4 & 88.3 & 87.4 \\
\hline
\end{tabular}

${ }^{1}$ Ephydra sp. (brine fly larvae) from Pond 4 after fall 2006 (highlighted by italics), Corixidae (water boatmen) from all other sites and sampling periods.

${ }^{2}$ D-pond was dry in fall 2008, Salton Sea National Wildlife Refuge Hazard Pond sampled in its place. 
Table 14. Arithmetic mean concentrations of trace elements ( $\mu \mathrm{g} / \mathrm{g}$, dry weight) in fresh Black-necked Stilt eggs collected from saline habitat ponds (SHP) and reference sites, Ecosystem Monitoring Project, Salton Sea, California, May-July 2006-08.

[Sample sizes for 2006: Pond $1(n=3)$, Pond $2(n=7)$, Freshwater Marsh $(n=6)$, D-Pond $(n=4)$.

Sample sizes for 2007: Pond $1(n=6)$, Pond $2(n=9)$, Pond $3(n=8)$, Pond $4(n=9)$, Morton Bay $(n=7)$

Freshwater Marsh ( $n=6)$, D-Pond $(n=1)$. Sample sizes for 2008: Pond $1(n=7)$, Pond $2(n=7)$, Pond $3(n=8)$, Pond $4(n=8)$, Freshwater Marsh $(n=10)$, Hazard $(n=10)$. Element definitions are given in table 8; ND, all concentrations were below limit of detection (LOD), which are provided in appendix 9. NQ, element not quantified. --, sites with no eggs collected]

\begin{tabular}{|c|c|c|c|c|c|}
\hline \multirow[b]{2}{*}{ Element } & \multirow[b]{2}{*}{ Group } & \multirow[b]{2}{*}{ Site } & \multicolumn{3}{|c|}{ Sampling period } \\
\hline & & & 2006 & 2007 & 2008 \\
\hline \multirow[t]{7}{*}{ Ag } & SHP & Pond 1 & 0.044 & 0.042 & ND \\
\hline & & Pond 2 & 0.027 & 0.043 & ND \\
\hline & & Pond 3 & -- & 0.035 & 0.025 \\
\hline & & Pond 4 & -- & 0.051 & ND \\
\hline & Reference & Morton Bay & -- & 0.024 & -- \\
\hline & & Freshwater Marsh & 0.052 & 0.037 & 0.030 \\
\hline & & D-Pond/Hazard & 0.030 & 0.048 & ND \\
\hline \multirow[t]{7}{*}{$\mathrm{Al}$} & SHP & Pond 1 & 1.43 & 0.608 & ND \\
\hline & & Pond 2 & 0.882 & 0.478 & ND \\
\hline & & Pond 3 & -- & 0.704 & 0.231 \\
\hline & & Pond 4 & -- & 0.835 & 0.230 \\
\hline & Reference & Morton Bay & -- & 1.93 & -- \\
\hline & & Freshwater Marsh & 0.722 & 0.489 & 0.259 \\
\hline & & D-Pond/Hazard & 0.715 & ND & 0.235 \\
\hline \multirow[t]{7}{*}{ As } & SHP & Pond 1 & 1.52 & 0.695 & ND \\
\hline & & Pond 2 & 1.06 & 0.885 & ND \\
\hline & & Pond 3 & -- & 0.843 & ND \\
\hline & & Pond 4 & -- & 0.951 & ND \\
\hline & Reference & Morton Bay & -- & 0.925 & -- \\
\hline & & Freshwater Marsh & 1.04 & 1.06 & ND \\
\hline & & D-Pond/Hazard & 1.05 & 0.859 & ND \\
\hline \multirow[t]{7}{*}{ B } & SHP & Pond 1 & 0.929 & 1.28 & 0.472 \\
\hline & & Pond 2 & 1.82 & 1.34 & 0.510 \\
\hline & & Pond 3 & -- & 1.50 & 0.709 \\
\hline & & Pond 4 & -- & 1.90 & 0.314 \\
\hline & Reference & Morton Bay & -- & 1.37 & -- \\
\hline & & Freshwater Marsh & 0.332 & 0.739 & 0.537 \\
\hline & & D-Pond/Hazard & 1.12 & 0.692 & 0.183 \\
\hline \multirow[t]{7}{*}{$\mathrm{Ba}$} & SHP & Pond 1 & 1.13 & 1.45 & 0.868 \\
\hline & & Pond 2 & 1.59 & 1.48 & 1.09 \\
\hline & & Pond 3 & -- & 1.58 & 1.45 \\
\hline & & Pond 4 & -- & 1.58 & 1.51 \\
\hline & Reference & Morton Bay & -- & 1.17 & -- \\
\hline & & Freshwater Marsh & 2.01 & 1.91 & 2.43 \\
\hline & & D-Pond/Hazard & 0.820 & 1.51 & 2.10 \\
\hline
\end{tabular}


Table 14. Arithmetic mean concentrations of trace elements ( $\mu \mathrm{g} / \mathrm{g}$, dry weight) in fresh Black-necked Stilt eggs collected from saline habitat ponds (SHP) and reference sites, Ecosystem Monitoring Project, Salton Sea, California, May-July 2006-08.-Continued

[Sample sizes for 2006: Pond $1(n=3)$, Pond $2(n=7)$, Freshwater Marsh $(n=6)$, D-Pond $(n=4)$.

Sample sizes for 2007: Pond $1(n=6)$, Pond $2(n=9)$, Pond $3(n=8)$, Pond $4(n=9)$, Morton Bay $(n=7)$ Freshwater Marsh $(n=6)$, D-Pond $(n=1)$. Sample sizes for 2008: Pond $1(n=7)$, Pond $2(n=7)$, Pond $3(n=8)$, Pond $4(n=8)$, Freshwater Marsh $(n=10)$, Hazard $(n=10)$. Element definitions are given in table 8 ; ND, all concentrations were below limit of detection (LOD), which are provided in appendix 9. NQ, element not quantified. --, sites with no eggs collected]

\begin{tabular}{|c|c|c|c|c|c|}
\hline \multirow[b]{2}{*}{ Element } & \multirow[b]{2}{*}{ Group } & \multirow[b]{2}{*}{ Site } & \multicolumn{3}{|c|}{ Sampling period } \\
\hline & & & 2006 & 2007 & 2008 \\
\hline \multirow[t]{7}{*}{$\mathrm{Be}$} & SHP & Pond 1 & 0.016 & 0.024 & 0.020 \\
\hline & & Pond 2 & 0.010 & 0.027 & 0.021 \\
\hline & & Pond 3 & -- & 0.024 & 0.016 \\
\hline & & Pond 4 & -- & 0.031 & 0.020 \\
\hline & Reference & Morton Bay & -- & 0.015 & -- \\
\hline & & Freshwater Marsh & 0.018 & 0.021 & 0.017 \\
\hline & & D-Pond/Hazard & 0.023 & 0.016 & 0.020 \\
\hline \multirow[t]{7}{*}{ Cd } & SHP & Pond 1 & 0.013 & 0.008 & ND \\
\hline & & Pond 2 & 0.008 & 0.021 & ND \\
\hline & & Pond 3 & -- & 0.014 & ND \\
\hline & & Pond 4 & -- & 0.019 & ND \\
\hline & Reference & Morton Bay & -- & 0.008 & -- \\
\hline & & Freshwater Marsh & 0.011 & 0.017 & ND \\
\hline & & D-Pond/Hazard & ND & ND & ND \\
\hline \multirow[t]{7}{*}{ Co } & SHP & Pond 1 & 0.034 & 0.047 & 0.016 \\
\hline & & Pond 2 & 0.039 & 0.052 & 0.039 \\
\hline & & Pond 3 & -- & 0.029 & 0.026 \\
\hline & & Pond 4 & -- & 0.050 & 0.014 \\
\hline & Reference & Morton Bay & -- & 0.017 & -- \\
\hline & & Freshwater Marsh & 0.037 & 0.044 & 0.026 \\
\hline & & D-Pond/Hazard & 0.053 & 0.064 & 0.025 \\
\hline \multirow[t]{7}{*}{$\mathrm{Cr}$} & SHP & Pond 1 & 0.191 & 0.188 & 0.172 \\
\hline & & Pond 2 & 0.275 & 0.177 & 0.197 \\
\hline & & Pond 3 & -- & 0.180 & 0.153 \\
\hline & & Pond 4 & -- & 0.205 & 0.172 \\
\hline & Reference & Morton Bay & -- & 0.474 & -- \\
\hline & & Freshwater Marsh & 0.252 & 0.223 & 0.156 \\
\hline & & D-Pond/Hazard & 0.178 & 0.145 & 0.187 \\
\hline \multirow[t]{7}{*}{$\mathrm{Cu}$} & SHP & Pond 1 & 3.61 & 3.85 & 3.40 \\
\hline & & Pond 2 & 3.40 & 8.41 & 3.63 \\
\hline & & Pond 3 & -- & 3.75 & 3.47 \\
\hline & & Pond 4 & -- & 3.86 & 3.67 \\
\hline & Reference & Morton Bay & -- & 3.65 & -- \\
\hline & & Freshwater Marsh & 3.48 & 3.64 & 3.57 \\
\hline & & D-Pond/Hazard & 3.49 & 3.40 & 3.62 \\
\hline
\end{tabular}


Table 14. Arithmetic mean concentrations of trace elements ( $\mu \mathrm{g} / \mathrm{g}$, dry weight) in fresh Black-necked Stilt eggs collected from saline habitat ponds (SHP) and reference sites, Ecosystem Monitoring Project, Salton Sea, California, May-July 2006-08.-Continued

[Sample sizes for 2006: Pond $1(n=3)$, Pond $2(n=7)$, Freshwater Marsh $(n=6)$, D-Pond $(n=4)$.

Sample sizes for 2007: Pond $1(n=6)$, Pond $2(n=9)$, Pond $3(n=8)$, Pond $4(n=9)$, Morton Bay $(n=7)$ Freshwater Marsh $(n=6)$, D-Pond $(n=1)$. Sample sizes for 2008: Pond $1(n=7)$, Pond $2(n=7)$, Pond $3(n=8)$, Pond $4(n=8)$, Freshwater Marsh $(n=10)$, Hazard $(n=10)$. Element definitions are given in table 8 ; ND, all concentrations were below limit of detection (LOD), which are provided in appendix 9. NQ, element not quantified. --, sites with no eggs collected]

\begin{tabular}{|c|c|c|c|c|c|}
\hline \multirow[b]{2}{*}{ Element } & \multirow[b]{2}{*}{ Group } & \multirow[b]{2}{*}{ Site } & \multicolumn{3}{|c|}{ Sampling period } \\
\hline & & & 2006 & 2007 & 2008 \\
\hline \multirow[t]{7}{*}{$\mathrm{Fe}$} & SHP & Pond 1 & 87.7 & 120 & 98.1 \\
\hline & & Pond 2 & 95.9 & 111 & 96.4 \\
\hline & & Pond 3 & -- & 125 & 108 \\
\hline & & Pond 4 & -- & 118 & 110 \\
\hline & Reference & Morton Bay & -- & 107 & -- \\
\hline & & Freshwater Marsh & 118 & 120 & 98.0 \\
\hline & & D-Pond/Hazard & 110 & 114 & 112 \\
\hline \multirow[t]{7}{*}{ Mn } & SHP & Pond 1 & 1.73 & 1.43 & 1.28 \\
\hline & & Pond 2 & 1.88 & 1.48 & 1.37 \\
\hline & & Pond 3 & -- & 1.55 & 1.14 \\
\hline & & Pond 4 & -- & 1.69 & 1.37 \\
\hline & Reference & Morton Bay & -- & 1.52 & -- \\
\hline & & Freshwater Marsh & 1.36 & 1.39 & 1.26 \\
\hline & & D-Pond/Hazard & 1.22 & 0.815 & 1.43 \\
\hline \multirow[t]{7}{*}{ Mo } & SHP & Pond 1 & 0.155 & 0.173 & 0.149 \\
\hline & & Pond 2 & 0.063 & 0.129 & 0.150 \\
\hline & & Pond 3 & -- & 0.131 & 0.138 \\
\hline & & Pond 4 & -- & 0.103 & 0.123 \\
\hline & Reference & Morton Bay & -- & 0.249 & -- \\
\hline & & Freshwater Marsh & 0.113 & 0.156 & 0.339 \\
\hline & & D-Pond/Hazard & 0.125 & 0.070 & 0.137 \\
\hline \multirow[t]{7}{*}{$\mathrm{Ni}$} & SHP & Pond 1 & 0.035 & 0.024 & 0.038 \\
\hline & & Pond 2 & 0.047 & 0.019 & 0.075 \\
\hline & & Pond 3 & -- & 0.022 & 0.039 \\
\hline & & Pond 4 & -- & 0.039 & 0.150 \\
\hline & Reference & Morton Bay & -- & 0.075 & -- \\
\hline & & Freshwater Marsh & 0.017 & 0.061 & 0.035 \\
\hline & & D-Pond/Hazard & 0.021 & ND & 0.084 \\
\hline \multirow[t]{7}{*}{$\mathrm{Pb}$} & SHP & Pond 1 & ND & ND & ND \\
\hline & & Pond 2 & 0.105 & 0.093 & ND \\
\hline & & Pond 3 & -- & 0.089 & ND \\
\hline & & Pond 4 & -- & 0.078 & ND \\
\hline & Reference & Morton Bay & -- & 0.090 & -- \\
\hline & & Freshwater Marsh & 0.089 & 0.098 & ND \\
\hline & & D-Pond/Hazard & 0.117 & ND & ND \\
\hline
\end{tabular}


Table 14. Arithmetic mean concentrations of trace elements ( $\mu \mathrm{g} / \mathrm{g}$, dry weight) in fresh Black-necked Stilt eggs collected from saline habitat ponds (SHP) and reference sites, Ecosystem Monitoring Project, Salton Sea, California, May-July 2006-08.-Continued

[Sample sizes for 2006: Pond $1(n=3)$, Pond $2(n=7)$, Freshwater Marsh $(n=6)$, D-Pond $(n=4)$.

Sample sizes for 2007: Pond $1(n=6)$, Pond $2(n=9)$, Pond $3(n=8)$, Pond $4(n=9)$, Morton Bay $(n=7)$ Freshwater Marsh $(n=6)$, D-Pond $(n=1)$. Sample sizes for 2008: Pond $1(n=7)$, Pond $2(n=7)$, Pond $3(n=8)$, Pond $4(n=8)$, Freshwater Marsh $(n=10)$, Hazard $(n=10)$. Element definitions are given in table 8 ; ND, all concentrations were below limit of detection (LOD), which are provided in appendix 9. NQ, element not quantified. --, sites with no eggs collected]

\begin{tabular}{|c|c|c|c|c|c|}
\hline \multirow[b]{2}{*}{ Element } & \multirow[b]{2}{*}{ Group } & \multirow[b]{2}{*}{ Site } & \multicolumn{3}{|c|}{ Sampling period } \\
\hline & & & 2006 & 2007 & 2008 \\
\hline \multirow[t]{7}{*}{$\mathrm{Sb}$} & SHP & Pond 1 & 2.32 & ND & ND \\
\hline & & Pond 2 & 1.73 & ND & ND \\
\hline & & Pond 3 & -- & ND & ND \\
\hline & & Pond 4 & -- & ND & 0.329 \\
\hline & Reference & Morton Bay & -- & ND & -- \\
\hline & & Freshwater Marsh & 1.10 & ND & 0.150 \\
\hline & & D-Pond/Hazard & 1.11 & ND & 0.143 \\
\hline \multirow[t]{7}{*}{ Se } & SHP & Pond 1 & 7.85 & 6.18 & 5.45 \\
\hline & & Pond 2 & 9.09 & 5.45 & 5.73 \\
\hline & & Pond 3 & -- & 6.06 & 6.99 \\
\hline & & Pond 4 & -- & 4.52 & 5.46 \\
\hline & Reference & Morton Bay & -- & 5.41 & -- \\
\hline & & Freshwater Marsh & 7.05 & 6.11 & 5.26 \\
\hline & & D-Pond/Hazard & 3.62 & 2.18 & 4.42 \\
\hline \multirow[t]{7}{*}{ Sn } & SHP & Pond 1 & 0.132 & ND & NQ \\
\hline & & Pond 2 & 0.139 & 0.006 & NQ \\
\hline & & Pond 3 & -- & ND & NQ \\
\hline & & Pond 4 & -- & ND & NQ \\
\hline & Reference & Morton Bay & -- & 0.009 & -- \\
\hline & & Freshwater Marsh & 0.125 & 0.012 & NQ \\
\hline & & D-Pond/Hazard & 0.088 & ND & NQ \\
\hline \multirow[t]{7}{*}{$\mathrm{Tl}$} & SHP & Pond 1 & 0.217 & 0.147 & ND \\
\hline & & Pond 2 & 0.221 & 0.137 & ND \\
\hline & & Pond 3 & -- & 0.144 & ND \\
\hline & & Pond 4 & -- & 0.155 & ND \\
\hline & Reference & Morton Bay & -- & ND & -- \\
\hline & & Freshwater Marsh & 0.161 & ND & ND \\
\hline & & D-Pond/Hazard & 0.147 & ND & ND \\
\hline \multirow[t]{7}{*}{ V } & SHP & Pond 1 & ND & ND & ND \\
\hline & & Pond 2 & ND & ND & ND \\
\hline & & Pond 3 & -- & ND & ND \\
\hline & & Pond 4 & -- & ND & ND \\
\hline & Reference & Morton Bay & -- & ND & -- \\
\hline & & Freshwater Marsh & ND & ND & ND \\
\hline & & D-Pond/Hazard & ND & ND & ND \\
\hline
\end{tabular}


Table 14. Arithmetic mean concentrations of trace elements ( $\mu \mathrm{g} / \mathrm{g}$, dry weight) in fresh Black-necked Stilt eggs collected from saline habitat ponds (SHP) and reference sites, Ecosystem Monitoring Project, Salton Sea, California, May-July 2006-08.-Continued

[Sample sizes for 2006: Pond $1(n=3)$, Pond $2(n=7)$, Freshwater Marsh $(n=6)$, D-Pond $(n=4)$.

Sample sizes for 2007: Pond $1(n=6)$, Pond $2(n=9)$, Pond $3(n=8)$, Pond $4(n=9)$, Morton Bay $(n=7)$ Freshwater Marsh $(n=6)$, D-Pond $(n=1)$. Sample sizes for 2008: Pond $1(n=7)$, Pond $2(n=7)$, Pond $3(n=8)$, Pond $4(n=8)$, Freshwater Marsh $(n=10)$, Hazard $(n=10)$. Element definitions are given in table 8 ; ND, all concentrations were below limit of detection (LOD), which are provided in appendix 9. NQ, element not quantified. --, sites with no eggs collected]

\begin{tabular}{|c|c|c|c|c|c|}
\hline \multirow[b]{2}{*}{ Element } & \multirow[b]{2}{*}{ Group } & \multirow[b]{2}{*}{ Site } & \multicolumn{3}{|c|}{ Sampling period } \\
\hline & & & 2006 & 2007 & 2008 \\
\hline \multirow[t]{7}{*}{$\mathrm{Zn}$} & SHP & Pond 1 & 49.4 & 57.8 & 46.5 \\
\hline & & Pond 2 & 51.6 & 61.7 & 47.9 \\
\hline & & Pond 3 & -- & 58.5 & 49.3 \\
\hline & & Pond 4 & -- & 64.3 & 51.8 \\
\hline & Reference & Morton Bay & -- & 55.9 & -- \\
\hline & & Freshwater Marsh & 50.8 & 55.5 & 47.0 \\
\hline & & D-Pond/Hazard & 46.7 & 46.3 & 52.0 \\
\hline \multirow[t]{7}{*}{$\begin{array}{l}\% \text { dry } \\
\text { weight }\end{array}$} & SHP & Pond 1 & 28.7 & 27.2 & 31.5 \\
\hline & & Pond 2 & 25.9 & 29.1 & 30.8 \\
\hline & & Pond 3 & -- & 28.3 & 31.0 \\
\hline & & Pond 4 & -- & 27.9 & 29.0 \\
\hline & Reference & Morton Bay & -- & 27.7 & -- \\
\hline & & Freshwater Marsh & 25.1 & 26.4 & 30.7 \\
\hline & & D-Pond/Hazard & 27.0 & 29.5 & 29.0 \\
\hline
\end{tabular}


Table 15. Arithmetic mean concentrations of organochlorine compounds ( $\mu \mathrm{g} / \mathrm{g}$, wet weight) in fresh Black-necked Stilt eggs collected from saline habitat ponds (SHP) and reference sites, Ecosystem Monitoring Project, Salton Sea, California, May-July 2006-08.

[Sample sizes are given in table 14. ND, all concentrations were below limit of detection (LOD), which are provided in appendix 10. NQ, element not quantified. --, sites with no eggs collected]

\begin{tabular}{|c|c|c|c|c|c|c|}
\hline \multirow[b]{2}{*}{$\begin{array}{l}\text { Organochlorine } \\
\text { group }\end{array}$} & \multirow[b]{2}{*}{ Compound } & \multirow[b]{2}{*}{ Group } & \multirow[b]{2}{*}{ Site } & \multicolumn{3}{|c|}{ Sampling period } \\
\hline & & & & 2006 & 2007 & 2008 \\
\hline \multirow[t]{42}{*}{ DDT } & $p, p^{\prime} \mathrm{DDD}$ & SHP & Pond 1 & 0.002 & 0.002 & ND \\
\hline & & & Pond 2 & 0.002 & 0.001 & 0.004 \\
\hline & & & Pond 3 & -- & 0.006 & ND \\
\hline & & & Pond 4 & -- & 0.002 & ND \\
\hline & & Reference & Morton Bay & -- & 0.003 & -- \\
\hline & & & Freshwater Marsh & ND & 0.001 & 0.003 \\
\hline & & & D-Pond/Hazard & 0.005 & ND & ND \\
\hline & $p, p^{\prime} \mathrm{DDE}$ & SHP & Pond 1 & 1.137 & 1.223 & 1.917 \\
\hline & & & Pond 2 & 3.413 & 2.954 & 1.983 \\
\hline & & & Pond 3 & -- & 3.358 & 2.363 \\
\hline & & & Pond 4 & -- & 6.351 & 1.898 \\
\hline & & Reference & Morton Bay & -- & 1.624 & -- \\
\hline & & & Freshwater Marsh & 1.315 & 1.029 & 1.951 \\
\hline & & & D-Pond/Hazard & 2.100 & 1.300 & 1.096 \\
\hline & $p, p^{\prime} \mathrm{DDT}$ & SHP & Pond 1 & ND & 0.008 & 0.008 \\
\hline & & & Pond 2 & 0.005 & 0.007 & 0.013 \\
\hline & & & Pond 3 & -- & 0.008 & 0.006 \\
\hline & & & Pond 4 & -- & 0.008 & 0.005 \\
\hline & & Reference & Morton Bay & -- & ND & -- \\
\hline & & & Freshwater Marsh & ND & 0.001 & 0.010 \\
\hline & & & D-Pond/Hazard & ND & ND & 0.004 \\
\hline & $o, p^{\prime} \mathrm{DDD}$ & SHP & Pond 1 & ND & ND & 0.002 \\
\hline & & & Pond 2 & ND & ND & 0.004 \\
\hline & & & Pond 3 & -- & 0.002 & 0.003 \\
\hline & & & Pond 4 & -- & ND & ND \\
\hline & & Reference & Morton Bay & -- & ND & -- \\
\hline & & & Freshwater Marsh & ND & ND & 0.002 \\
\hline & & & D-Pond/Hazard & ND & ND & ND \\
\hline & $o, p^{\prime} \mathrm{DDE}$ & SHP & Pond 1 & ND & ND & 0.008 \\
\hline & & & Pond 2 & ND & ND & 0.012 \\
\hline & & & Pond 3 & -- & ND & 0.003 \\
\hline & & & Pond 4 & -- & ND & ND \\
\hline & & Reference & Morton Bay & -- & ND & -- \\
\hline & & & Freshwater Marsh & ND & ND & ND \\
\hline & & & D-Pond/Hazard & ND & ND & ND \\
\hline & $o, p^{\prime} \mathrm{DDT}$ & SHP & Pond 1 & ND & ND & ND \\
\hline & & & Pond 2 & ND & ND & 0.002 \\
\hline & & & Pond 3 & -- & ND & ND \\
\hline & & & Pond 4 & -- & ND & ND \\
\hline & & Reference & Morton Bay & -- & ND & -- \\
\hline & & & Freshwater Marsh & ND & ND & ND \\
\hline & & & D-Pond/Hazard & ND & ND & ND \\
\hline
\end{tabular}


Table 15. Arithmetic mean concentrations of organochlorine compounds ( $\mu \mathrm{g} / \mathrm{g}$, wet weight) in fresh Black-necked Stilt eggs collected from saline habitat ponds (SHP) and reference sites, Ecosystem Monitoring Project, Salton Sea, California, May-July 2006-08.-Continued

[Sample sizes are given in table 14. ND, all concentrations were below limit of detection (LOD), which are provided in appendix 10. NQ, element not quantified. --, sites with no eggs collected]

\begin{tabular}{|c|c|c|c|c|c|c|}
\hline \multirow[b]{2}{*}{$\begin{array}{l}\text { Organochlorine } \\
\text { group }\end{array}$} & \multirow[b]{2}{*}{ Compound } & \multirow[b]{2}{*}{ Group } & \multirow[b]{2}{*}{ Site } & \multicolumn{3}{|c|}{ Sampling period } \\
\hline & & & & 2006 & 2007 & 2008 \\
\hline \multirow[t]{43}{*}{ Chlordane } & alpha chlordane & SHP & Pond 1 & ND & ND & ND \\
\hline & & & Pond 2 & ND & ND & 0.002 \\
\hline & & & Pond 3 & -- & ND & ND \\
\hline & & & Pond 4 & -- & ND & ND \\
\hline & & Reference & Morton Bay & -- & ND & -- \\
\hline & & & Freshwater Marsh & ND & ND & ND \\
\hline & & & D-Pond/Hazard & ND & ND & ND \\
\hline & gamma chlordane & SHP & Pond 1 & ND & ND & 0.004 \\
\hline & & & Pond 2 & ND & ND & 0.005 \\
\hline & & & Pond 3 & -- & ND & 0.008 \\
\hline & & & Pond 4 & -- & ND & 0.004 \\
\hline & & Reference & Morton Bay & -- & ND & -- \\
\hline & & & Freshwater Marsh & ND & ND & 0.003 \\
\hline & & & D-Pond/Hazard & ND & ND & 0.003 \\
\hline & oxychlordane & SHP & Pond 1 & 0.002 & 0.006 & 0.004 \\
\hline & & & Pond 2 & 0.002 & 0.006 & 0.006 \\
\hline & & & Pond 3 & -- & 0.006 & 0.006 \\
\hline & & & Pond 4 & -- & 0.008 & 0.004 \\
\hline & & Reference & Morton Bay & -- & 0.003 & -- \\
\hline & & & Freshwater Marsh & 0.003 & 0.004 & 0.003 \\
\hline & & & D-Pond/Hazard & 0.003 & 0.004 & ND \\
\hline & cis-nonachlor & SHP & Pond 1 & ND & ND & 0.002 \\
\hline & & & Pond 2 & ND & ND & ND \\
\hline & & & Pond 3 & -- & ND & 0.002 \\
\hline & & & Pond 4 & -- & ND & 0.002 \\
\hline & & Reference & Morton Bay & -- & ND & -- \\
\hline & & & Freshwater Marsh & ND & ND & 0.002 \\
\hline & & & D-Pond/Hazard & ND & ND & ND \\
\hline & trans-nonachlor & SHP & Pond 1 & ND & ND & ND \\
\hline & & & Pond 2 & ND & ND & 0.004 \\
\hline & & & Pond 3 & -- & ND & 0.002 \\
\hline & & & Pond 4 & -- & ND & 0.002 \\
\hline & & Reference & Morton Bay & -- & ND & -- \\
\hline & & & Freshwater Marsh & 0.001 & ND & ND \\
\hline & & & D-Pond/Hazard & 0.003 & ND & 0.002 \\
\hline & $\begin{array}{l}\text { heptachlor } \\
\text { epoxide }\end{array}$ & SHP & Pond 1 & ND & ND & ND \\
\hline & & & Pond 2 & ND & ND & 0.003 \\
\hline & & & Pond 3 & -- & ND & 0.002 \\
\hline & & & Pond 4 & -- & 0.001 & 0.002 \\
\hline & & Reference & Morton Bay & -- & ND & -- \\
\hline & & & Freshwater Marsh & ND & ND & ND \\
\hline & & & D-Pond/Hazard & ND & ND & 0.001 \\
\hline & & & 121 & & & \\
\hline
\end{tabular}


Table 15. Arithmetic mean concentrations of organochlorine compounds ( $\mu \mathrm{g} / \mathrm{g}$, wet weight) in fresh Black-necked Stilt eggs collected from saline habitat ponds (SHP) and reference sites, Ecosystem Monitoring Project, Salton Sea, California, May-July 2006-08.-Continued

[Sample sizes are given in table 14. ND, all concentrations were below limit of detection (LOD), which are provided in appendix 10. NQ, element not quantified. --, sites with no eggs collected]

\begin{tabular}{|c|c|c|c|c|c|c|}
\hline \multirow[b]{2}{*}{$\begin{array}{l}\text { Organochlorine } \\
\text { group }\end{array}$} & \multirow[b]{2}{*}{ Compound } & \multirow[b]{2}{*}{ Group } & \multirow[b]{2}{*}{ Site } & \multicolumn{3}{|c|}{ Sampling period } \\
\hline & & & & 2006 & 2007 & 2008 \\
\hline \multirow{28}{*}{$\begin{array}{l}\text { Hexachloro- } \\
\text { cyclohexane }\end{array}$} & alpha BHC & SHP & Pond 1 & ND & ND & ND \\
\hline & & & Pond 2 & ND & ND & 0.002 \\
\hline & & & Pond 3 & -- & ND & ND \\
\hline & & & Pond 4 & -- & ND & ND \\
\hline & & Reference & $\begin{array}{l}\text { Morton Bay } \\
\text { Freshwater }\end{array}$ & -- & ND & -- \\
\hline & & & Marsh & ND & ND & ND \\
\hline & & & D-Pond/Hazard & ND & ND & ND \\
\hline & beta BHC & SHP & Pond 1 & ND & 0.003 & 0.010 \\
\hline & & & Pond 2 & ND & 0.008 & 0.006 \\
\hline & & & Pond 3 & -- & 0.006 & 0.007 \\
\hline & & & Pond 4 & -- & 0.005 & ND \\
\hline & & Reference & $\begin{array}{l}\text { Morton Bay } \\
\text { Freshwater }\end{array}$ & -- & 0.003 & -- \\
\hline & & & Marsh & ND & 0.001 & 0.004 \\
\hline & & & D-Pond/Hazard & ND & ND & 0.002 \\
\hline & delta BHC & Study Ponds & Pond 1 & ND & NQ & NQ \\
\hline & & & Pond 2 & ND & NQ & NQ \\
\hline & & & Pond 3 & -- & NQ & NQ \\
\hline & & & Pond 4 & -- & NQ & NQ \\
\hline & & Reference & $\begin{array}{l}\text { Morton Bay } \\
\text { Freshwater }\end{array}$ & -- & NQ & NQ \\
\hline & & & Marsh & ND & NQ & NQ \\
\hline & & & D-Pond/Hazard & ND & NQ & NQ \\
\hline & gamma BHC & SHP & Pond 1 & ND & ND & ND \\
\hline & & & Pond 2 & ND & ND & 0.003 \\
\hline & & & Pond 3 & -- & ND & ND \\
\hline & & & Pond 4 & -- & ND & ND \\
\hline & & Reference & $\begin{array}{l}\text { Morton Bay } \\
\text { Freshwater }\end{array}$ & -- & ND & -- \\
\hline & & & Marsh & ND & ND & 0.002 \\
\hline & & & D-Pond/Hazard & ND & ND & ND \\
\hline
\end{tabular}


Table 15. Arithmetic mean concentrations of organochlorine compounds ( $\mu \mathrm{g} / \mathrm{g}$, wet weight) in fresh Black-necked Stilt eggs collected from saline habitat ponds (SHP) and reference sites, Ecosystem Monitoring Project, Salton Sea, California, May-July 2006-08.-Continued

[Sample sizes are given in table 14. ND, all concentrations were below limit of detection (LOD), which are provided in appendix 10. NQ, element not quantified. --, sites with no eggs collected]

\begin{tabular}{|c|c|c|c|c|c|c|}
\hline \multirow[b]{2}{*}{$\begin{array}{l}\text { Organochlorine } \\
\text { group }\end{array}$} & \multirow[b]{2}{*}{ Compound } & \multirow[b]{2}{*}{ Group } & \multirow[b]{2}{*}{ Site } & \multicolumn{3}{|c|}{ Sampling Period } \\
\hline & & & & 2006 & 2007 & 2008 \\
\hline \multirow[t]{14}{*}{ Drin } & dieldrin & SHP & Pond 1 & ND & 0.011 & 0.012 \\
\hline & & & Pond 2 & ND & 0.009 & 0.010 \\
\hline & & & Pond 3 & -- & 0.008 & 0.020 \\
\hline & & & Pond 4 & -- & 0.028 & 0.013 \\
\hline & & Reference & Morton Bay & -- & 0.011 & -- \\
\hline & & & Freshwater Marsh & ND & 0.005 & 0.009 \\
\hline & & & D-Pond/Hazard & ND & ND & 0.014 \\
\hline & endrin & SHP & Pond 1 & ND & ND & ND \\
\hline & & & Pond 2 & ND & ND & ND \\
\hline & & & Pond 3 & -- & ND & 0.002 \\
\hline & & & Pond 4 & -- & ND & 0.002 \\
\hline & & Reference & Morton Bay & -- & ND & -- \\
\hline & & & Freshwater Marsh & ND & ND & ND \\
\hline & & & D-Pond/Hazard & ND & ND & ND \\
\hline \multirow[t]{7}{*}{ PCB } & Total PCBs & SHP & Pond 1 & ND & ND & 0.254 \\
\hline & & & Pond 2 & ND & ND & 0.247 \\
\hline & & & Pond 3 & -- & ND & 0.288 \\
\hline & & & Pond 4 & -- & ND & 0.210 \\
\hline & & Reference & Morton Bay & -- & ND & -- \\
\hline & & & Freshwater Marsh & ND & ND & 0.218 \\
\hline & & & D-Pond/Hazard & ND & ND & 0.178 \\
\hline \multirow[t]{7}{*}{ Chlorobenzene } & НСB & SHP & Pond 1 & 0.001 & 0.005 & 0.003 \\
\hline & & & Pond 2 & 0.002 & 0.004 & 0.008 \\
\hline & & & Pond 3 & -- & 0.006 & 0.004 \\
\hline & & & Pond 4 & -- & 0.006 & 0.003 \\
\hline & & Reference & Morton Bay & -- & 0.003 & -- \\
\hline & & & Freshwater Marsh & 0.002 & 0.002 & 0.002 \\
\hline & & & D-Pond/Hazard & 0.003 & ND & 0.001 \\
\hline
\end{tabular}


Table 15. Arithmetic mean concentrations of organochlorine compounds ( $\mu \mathrm{g} / \mathrm{g}$, wet weight) in fresh Black-necked Stilt eggs collected from saline habitat ponds (SHP) and reference sites, Ecosystem Monitoring Project, Salton Sea, California, May-July 2006-08.-Continued

[Sample sizes are given in table 14. ND, all concentrations were below limit of detection (LOD), which are provided in appendix 10. NQ, element not quantified. --, sites with no eggs collected]

\begin{tabular}{|c|c|c|c|c|c|c|}
\hline \multirow[b]{2}{*}{$\begin{array}{l}\text { Organochlorine } \\
\text { group }\end{array}$} & \multirow[b]{2}{*}{ Compound } & \multirow[b]{2}{*}{ Group } & \multirow[b]{2}{*}{ Site } & \multicolumn{3}{|c|}{ Sampling period } \\
\hline & & & & 2006 & 2007 & 2008 \\
\hline \multirow[t]{28}{*}{ Other } & mirex & SHP & Pond 1 & ND & ND & 0.278 \\
\hline & & & Pond 2 & ND & ND & 0.003 \\
\hline & & & Pond 3 & -- & ND & ND \\
\hline & & & Pond 4 & -- & ND & ND \\
\hline & & Reference & Morton Bay & -- & ND & -- \\
\hline & & & Freshwater Marsh & ND & ND & ND \\
\hline & & & D-Pond/Hazard & ND & ND & 0.002 \\
\hline & toxaphene & SHP & Pond 1 & ND & ND & ND \\
\hline & & & Pond 2 & ND & ND & ND \\
\hline & & & Pond 3 & -- & ND & ND \\
\hline & & & Pond 4 & -- & ND & ND \\
\hline & & Reference & Morton Bay & -- & ND & -- \\
\hline & & & Freshwater Marsh & ND & ND & ND \\
\hline & & & D-Pond/Hazard & ND & ND & ND \\
\hline & \% Lipid & SHP & Pond 1 & 12.6 & 11.2 & 13.6 \\
\hline & & & Pond 2 & 12.1 & 12.0 & 14.5 \\
\hline & & & Pond 3 & -- & 12.0 & 12.5 \\
\hline & & & Pond 4 & -- & 10.0 & 14.9 \\
\hline & & Reference & Morton Bay & -- & 12.6 & -- \\
\hline & & & Freshwater Marsh & 10.6 & 11.6 & 14.0 \\
\hline & & & D-Pond/Hazard & 13.7 & 13.6 & 12.9 \\
\hline & \% Moisture & SHP & Pond 1 & 71.4 & 75.5 & 78.4 \\
\hline & & & Pond 2 & 73.1 & 73.3 & 75.8 \\
\hline & & & Pond 3 & -- & 75.2 & 76.1 \\
\hline & & & Pond 4 & -- & 72.9 & 80.4 \\
\hline & & Reference & Morton Bay & -- & 75.1 & -- \\
\hline & & & Freshwater Marsh & 75.3 & 73.8 & 81.5 \\
\hline & & & D-Pond/Hazard & 75.7 & 63.6 & 78.0 \\
\hline
\end{tabular}


Table 16. Estimates for 95\% (home range) and 50\% (core area) utilization distributions for radio marked Black-necked Stilt chicks during the 2006-08 breeding seasons, Ecosystem Monitoring Project, Salton Sea, California.

[SHP, saline habitat ponds. Number: Number of locations and chicks used to calculate population spatial use estimates. UD, utilization distributions. ha, hectares; \%, percent]

\begin{tabular}{|c|c|c|c|c|c|c|}
\hline \multirow[b]{2}{*}{ Year } & \multirow[b]{2}{*}{ Group } & \multirow[b]{2}{*}{ Hatch site } & \multicolumn{2}{|c|}{ Number } & \multicolumn{2}{|c|}{ Area (ha) } \\
\hline & & & locations & chicks & $95 \%$ UD & $50 \%$ UD \\
\hline 2006 & SHP & All ponds & 253 & 18 & 143 & 16 \\
\hline \multirow[t]{2}{*}{2007} & SHP & All ponds & 310 & 39 & 148 & 7 \\
\hline & & Hazard & 134 & 15 & 85 & 12 \\
\hline \multirow[t]{3}{*}{2008} & SHP & All ponds & 180 & 20 & 212 & 28 \\
\hline & Reference & $\begin{array}{l}\text { Hazard } \\
\text { Freshwater }\end{array}$ & 143 & 10 & 66 & 10 \\
\hline & & Marsh & 127 & 9 & 5 & 1 \\
\hline
\end{tabular}


Table 17. Proportion of Black-necked Stilt chick locations occurring within a hatch pond and proportion of stilt chicks with more than one location in a non-hatch pond during the 2006-08 breeding seasons at the saline habitat ponds (SHP), Ecosystem Monitoring Project, Salton Sea, California.

[Hatch pond: Based on pond where chicks hatched. Ponds 3 and 4 were dry with no nesting during 2006]

\begin{tabular}{|c|c|c|c|c|c|}
\hline Year & Hatch pond & $\begin{array}{c}\text { Total } \\
\text { number of } \\
\text { locations }\end{array}$ & $\begin{array}{l}\text { Percentage of } \\
\text { locations in } \\
\text { hatch pond }\end{array}$ & $\begin{array}{l}\text { Total } \\
\text { number of } \\
\text { chicks }\end{array}$ & $\begin{array}{l}\text { Percentage of } \\
\text { chicks with } \\
\text { movement in } \\
\text { non-hatch pond }\end{array}$ \\
\hline \multirow[t]{4}{*}{2006} & Pond 1 & 55 & 84 & 13 & 46 \\
\hline & Pond 2 & 42 & 67 & 5 & 100 \\
\hline & All SHP & & & & \\
\hline & Ponds & 97 & 76 & 18 & 61 \\
\hline \multirow[t]{6}{*}{2007} & Pond 1 & 45 & 87 & 9 & 44 \\
\hline & Pond 2 & 19 & 84 & 8 & 25 \\
\hline & Pond 3 & 26 & 85 & 11 & 33 \\
\hline & Pond 4 & 22 & 77 & 8 & 14 \\
\hline & All SHP & & & & \\
\hline & Ponds & 112 & 84 & 36 & 30 \\
\hline \multirow[t]{6}{*}{2008} & Pond 1 & -- & -- & -- & -- \\
\hline & Pond 2 & 11 & 36 & 3 & ${ }^{1} 67$ \\
\hline & Pond 3 & 2 & 100 & 4 & 0 \\
\hline & Pond 4 & 21 & 67 & 13 & 23 \\
\hline & All SHP & & & & \\
\hline & Ponds & 34 & 59 & 20 & 30 \\
\hline
\end{tabular}

${ }^{1}$ All Pond 2 non-hatch pond locations during 2008 occurred in Pond 1. 
Table 18. Descriptive statistics for movements by post-hatch Black-necked Stilt chicks during the $2006-08$ breeding seasons, Ecosystem Monitoring Project, Salton Sea, California.

[SHP, saline habitat ponds. m, meters; \%, percent; --, no marked chicks]

\begin{tabular}{|c|c|c|c|c|c|c|c|c|c|c|}
\hline \multirow[b]{3}{*}{ Year } & \multirow[b]{3}{*}{ Variable } & \multirow[b]{3}{*}{ Parameter } & \multicolumn{8}{|c|}{ Hatch site } \\
\hline & & & \multicolumn{5}{|c|}{ SHP ponds } & \multicolumn{3}{|c|}{ Reference } \\
\hline & & & Pond 1 & Pond 2 & Pond 3 & Pond 4 & All SHP & Hazard & $\begin{array}{l}\text { Freshmat } \\
\text { er Marsh }\end{array}$ & $\begin{array}{c}\text { All } \\
\text { reference }\end{array}$ \\
\hline \multirow[t]{10}{*}{2006} & Max distance from nest (m) & mean & $\begin{array}{l}1,212 \\
124-\end{array}$ & 515 & -- & -- & 1,018 & -- & -- & -- \\
\hline & & range & 2,023 & 290-709 & -- & -- & $124-1,764$ & -- & -- & -- \\
\hline & & & & & -- & -- & & -- & -- & -- \\
\hline & Angle of max distance from nest (degrees) & mean & $331^{\circ}$ & $300^{\circ}$ & & & $322^{\circ}$ & & & \\
\hline & & & & & -- & -- & & -- & -- & -- \\
\hline & Distance between locations (m) & mean & 160 & 171 & -- & -- & 163 & -- & -- & -- \\
\hline & & range & 95-233 & 60-282 & & & $95-282$ & & & \\
\hline & Number of days to emigration & median & 3.0 & 1.0 & -- & -- & 2.5 & -- & -- & -- \\
\hline & & range & $1-5$ & $1-1$ & -- & -- & $1-5$ & -- & -- & -- \\
\hline & Percentage of chicks emigrating ${ }^{1}$ & $\%$ & $69 \%$ & $33 \%$ & -- & -- & $59 \%$ & -- & -- & -- \\
\hline \multirow[t]{8}{*}{2007} & Max distance from nest (m) & mean & $\begin{array}{l}758 \\
121-\end{array}$ & 589 & 667 & 964 & 730 & 584 & -- & 546 \\
\hline & & range & 1,310 & $12-1,717$ & $4-1,531$ & $231-1,766$ & $4-1,766$ & $40-1,128$ & -- & $40-1,128$ \\
\hline & Angle of max distance from nest (degrees) & mean & $317^{\circ}$ & $286^{\circ}$ & $314^{\circ}$ & $324^{\circ}$ & $311^{\circ}$ & $88^{\circ}$ & -- & $88^{\circ}$ \\
\hline & Distance between locations (m) & mean & 182 & 185 & 173 & 210 & 186 & 124 & -- & 124 \\
\hline & & range & $4-1,139$ & $2-755$ & $1-1,531$ & $0-832$ & $0-1,531$ & $1-1,073$ & -- & $1-1,073$ \\
\hline & Number of days to emigration & median & 6.0 & 2.0 & 2.0 & 2.0 & 2.5 & 5.5 & -- & 5.5 \\
\hline & & range & $2-17$ & $1-4$ & $1-5$ & $1-5$ & $1-17$ & $5-7$ & -- & $5-7$ \\
\hline & Percentage of chicks emigrating ${ }^{1}$ & $\%$ & $78 \%$ & $83 \%$ & $82 \%$ & $100 \%$ & $85 \%$ & $60 \%$ & -- & $60 \%$ \\
\hline \multirow[t]{8}{*}{2008} & Max distance from nest (m) & mean & -- & 205 & 543 & 749 & 609 & 416 & 175 & 302 \\
\hline & & range & -- & $8-589$ & $45-1,125$ & $33-1,604$ & $8-1,604$ & $169-895$ & $37-429$ & 37-895 \\
\hline & Angle of max distance from nest (degrees) & mean & & $259^{\circ}$ & $294^{\circ}$ & $325^{\circ}$ & $304^{\circ}$ & $154^{\circ}$ & $337^{\circ}$ & $149^{\circ}$ \\
\hline & Distance between locations (m) & -- & -- & 75 & 155 & 165 & 155 & 106 & 52 & 81 \\
\hline & & range & -- & $1-320$ & $6-854$ & 3-889 & $1-889$ & $1-562$ & $0-413$ & $0-562$ \\
\hline & Number of days to emigration & median & -- & 3.0 & 1.5 & 2.0 & 2.0 & 3.0 & -- & 3.0 \\
\hline & & range & -- & -- & $1-2$ & $1-5$ & $1-5$ & -- & -- & -- \\
\hline & Percentage of chicks emigrating $^{1}$ & $\%$ & -- & $25 \%$ & $100 \%$ & $77 \%$ & $68 \%$ & $10 \%$ & $0 \%$ & $5 \%$ \\
\hline
\end{tabular}

${ }^{1}$ Conservative estimate only that includes chicks surviving more than 3 days post hatch; see text for rationale. 
Table 19. Sunival rate estimates (S(t)) to 21 days post hatch for black-necked stilt chicks during the $2006-08$ breeding seasons, Ecosystem Monitoring Project, Salton Sea, California.

[See text methods section 4.2.2.2-Survival estimation for definitions of scenarios and methods for estimating survival. Both scenarios exclude mortalities associated with capture (2007: $\mathrm{n}=2$; 2008: $\mathrm{n}=4$ ). SHP, saline habitat ponds. \%, percent]

\begin{tabular}{|c|c|c|c|c|c|c|c|c|}
\hline Year & Censor scenario & Group & Hatch site & $\begin{array}{l}\text { Number } \\
\text { marked }\end{array}$ & $\begin{array}{c}\text { Number } \\
\text { died }\end{array}$ & $\begin{array}{l}\text { Number } \\
\text { censored }\end{array}$ & $S(t)$ & $95 \% \mathrm{Cl}^{1}$ \\
\hline \multirow[t]{2}{*}{2006} & Scenario 1 & SHP & SHP Ponds 1\&2 & 18 & 5 & 13 & 0.71 & $0.49-0.92$ \\
\hline & Scenario 2 & SHP & SHP Ponds $1 \& 2$ & 18 & 9 & 9 & 0.49 & $0.25-0.72$ \\
\hline \multirow[t]{10}{*}{2007} & Scenario 1 & SHP & SHP Ponds $1 \& 2$ & 17 & 8 & 9 & 0.52 & $0.28-0.76$ \\
\hline & & & SHP Ponds $3 \& 4$ & 21 & 11 & 10 & 0.35 & $0.10-0.60$ \\
\hline & & & All SHP & 38 & 19 & 19 & 0.45 & $0.27-0.62$ \\
\hline & & Reference & Hazard & 10 & 1 & 9 & 0.83 & $0.68-1.0$ \\
\hline & & & All Reference & 14 & 2 & 12 & 0.83 & $0.62-1.0$ \\
\hline & Scenario 2 & SHP & SHP Ponds $1 \& 2$ & 17 & 8 & 9 & 0.52 & $0.28-0.76$ \\
\hline & & & SHP Ponds 3\&4 & 21 & 13 & 8 & 0.27 & $0.06-0.49$ \\
\hline & & & All SHP & 38 & 21 & 17 & 0.40 & $0.23-0.56$ \\
\hline & & Reference & Hazard & 10 & 1 & 9 & 0.83 & $0.68-1.0$ \\
\hline & & & All Reference & 14 & 4 & 10 & 0.71 & $0.46-0.95$ \\
\hline \multirow[t]{12}{*}{2008} & Scenario 1 & SHP & SHP Ponds $1 \& 2$ & 12 & 6 & 6 & 0.38 & $0.05-0.70$ \\
\hline & & & SHP Ponds 3\&4 & 19 & 9 & 10 & 0.43 & $0.16-0.70$ \\
\hline & & & All SHP & 31 & 15 & 16 & 0.37 & $0.14-0.60$ \\
\hline & & Reference & Hazard & 14 & 3 & 11 & 0.76 & $0.52-1.00$ \\
\hline & & & Freshwater Marsh & 11 & 6 & 5 & 0.45 & $0.16-0.75$ \\
\hline & & & All Reference & 25 & 9 & 16 & 0.60 & $0.40-080$ \\
\hline & Scenario 2 & SHP & SHP Ponds $1 \& 2$ & 12 & 11 & 1 & 0.08 & $0.00-0.24$ \\
\hline & & & SHP Ponds $3 \& 4$ & 19 & 13 & 6 & 0.28 & $0.07-0.50$ \\
\hline & & & All SHP & 31 & 24 & 7 & 0.19 & $0.04-0.34$ \\
\hline & & Reference & Hazard & 14 & 7 & 7 & 0.50 & $0.24-0.76$ \\
\hline & & & Freshwater Marsh & 11 & 6 & 5 & 0.45 & $0.16-0.75$ \\
\hline & & & All Reference & 25 & 13 & 12 & 0.48 & $0.28-0.68$ \\
\hline
\end{tabular}

${ }^{\mathrm{T}}$ Values truncated between 0 and 1. 
Table 20. Probable causes of death for radio-marked post hatch black-necked stilt chicks during the 2006-08 breeding seasons, Ecosystem Monitoring project, Salton Sea, California.

[Cause of death by scenario: Numbers outside parentheses for Scenario 1, numbers inside parentheses for Scenario 2. See text for scenario definitions.

SHP, saline habitat ponds]

\begin{tabular}{|c|c|c|c|c|c|c|c|c|c|c|c|}
\hline \multirow[b]{2}{*}{ Year } & \multirow[b]{2}{*}{ Group } & \multirow[b]{2}{*}{ Hatch Site } & \multicolumn{9}{|c|}{ Cause of death by scenario } \\
\hline & & & $\begin{array}{c}\text { Avian } \\
\text { predator }\end{array}$ & $\begin{array}{l}\text { Mammalian } \\
\text { predator }\end{array}$ & $\begin{array}{l}\text { Unknown } \\
\text { predator }\end{array}$ & Canal & $\begin{array}{c}\text { Crack } \\
\text { entrapment }\end{array}$ & $\begin{array}{c}\text { Flood- } \\
\text { foam }\end{array}$ & Misc & $\begin{array}{l}\text { Unknown } \\
\text { death }\end{array}$ & $\begin{array}{c}\text { Total } \\
\text { deaths }\end{array}$ \\
\hline \multirow[t]{3}{*}{2006} & SHP & Pond 1 & $0(0)$ & $0(0)$ & $0(2)$ & $0(0)$ & $3(3)$ & $0(0)$ & $0(0)$ & $0(0)$ & $3(5)$ \\
\hline & & Pond 2 & $0(0)$ & $0(0)$ & $0(0)$ & $0(1)$ & $1(1)$ & $0(0)$ & $0(0)$ & $1(2)$ & $2(4)$ \\
\hline & & All SHP & $0(0)$ & $0(0)$ & $0(2)$ & $0(1)$ & $4(4)$ & $0(0)$ & $0(0)$ & $1(2)$ & $5(9)$ \\
\hline \multirow[t]{10}{*}{2007} & SHP & Pond 1 & $0(0)$ & $0(0)$ & $0(0)$ & $1(1)$ & $0(0)$ & $0(0)$ & $1(1)$ & $1(1)$ & $3(3)$ \\
\hline & & Pond 2 & $2(2)$ & $0(0)$ & $0(0)$ & $3(3)$ & $0(0)$ & $0(0)$ & $0(0)$ & $0(0)$ & $5(5)$ \\
\hline & & Pond 3 & $0(0)$ & $0(0)$ & $0(0)$ & $0(0)$ & $1(1)$ & $1(1)$ & $1(1)$ & $3(4)$ & $6(7)$ \\
\hline & & Pond 4 & $0(0)$ & $0(0)$ & $0(0)$ & $0(0)$ & $0(0)$ & $3(3)$ & $0(0)$ & $2(3)$ & $5(6)$ \\
\hline & & All SHP & $2(2)$ & $0(0)$ & $0(0)$ & $4(4)$ & $1(1)$ & $4(4)$ & $2(2)$ & $6(8)$ & $19(21)$ \\
\hline & Reference & $\begin{array}{l}\text { D Pond / Morton } \\
\text { Bay } \\
\text { Freshwater }\end{array}$ & $1(2)$ & $0(0)$ & $0(0)$ & $0(0)$ & $0(0)$ & $0(0)$ & $0(0)$ & $0(1)$ & $1(3)$ \\
\hline & & Marsh & $0(0)$ & $0(0)$ & $0(0)$ & $0(0)$ & $0(0)$ & $0(0)$ & $0(0)$ & $0(0)$ & $0(0)$ \\
\hline & & Hazard & $1(1)$ & $0(0)$ & $0(0)$ & $0(0)$ & $0(0)$ & $0(0)$ & $0(0)$ & $0(0)$ & $1(1)$ \\
\hline & & All Reference & $2(3)$ & $0(0)$ & $0(0)$ & $0(0)$ & $0(0)$ & $0(0)$ & $0(0)$ & $0(1)$ & $2(4)$ \\
\hline & & All sites & $4(5)$ & $0(0)$ & $0(0)$ & $4(4)$ & $1(1)$ & $4(4)$ & $2(2)$ & $6(9)$ & $21(25)$ \\
\hline \multirow[t]{9}{*}{2008} & SHP & Pond 1 & $1(1)$ & $0(0)$ & $1(1)$ & $0(0)$ & $0(0)$ & $0(0)$ & $0(0)$ & $1(1)$ & $3(3)$ \\
\hline & & Pond 2 & $3(4)$ & $0(0)$ & $0(3)$ & $0(1)$ & $0(0)$ & $0(0)$ & $0(0)$ & $0(0)$ & $3(8)$ \\
\hline & & Pond 3 & $2(2)$ & $1(1)$ & $0(1)$ & $0(1)$ & $1(1)$ & $0(0)$ & $0(0)$ & $0(0)$ & $4(6)$ \\
\hline & & Pond 4 & $3(3)$ & $0(0)$ & $0(2)$ & $2(2)$ & $0(0)$ & $0(0)$ & $0(0)$ & $0(0)$ & $5(7)$ \\
\hline & & $\begin{array}{l}\text { All SHP } \\
\text { Freshwater }\end{array}$ & $9(10)$ & $1(1)$ & $1(7)$ & $2(4)$ & $1(1)$ & $0(0)$ & $0(0)$ & $1(1)$ & $15(24)$ \\
\hline & Reference & Marsh & $2(2)$ & $3(3)$ & $0(0)$ & $1(1)$ & $0(0)$ & $0(0)$ & $0(0)$ & $0(0)$ & $6(6)$ \\
\hline & & Hazard & $1(1)$ & $1(1)$ & $0(4)$ & $0(0)$ & $0(0)$ & $0(0)$ & $0(0)$ & $1(1)$ & $3(7)$ \\
\hline & & All Reference & $3(3)$ & $4(4)$ & $0(4)$ & $1(1)$ & $0(0)$ & $0(0)$ & $0(0)$ & $1(1)$ & $9(13)$ \\
\hline & & All sites & 12 (13) & $5(5)$ & 1 (11) & $3(5)$ & $1(1)$ & $0(0)$ & $0(0)$ & $2(2)$ & 24 (37) \\
\hline \multicolumn{12}{|l|}{ All } \\
\hline Years & & All sites & $16(18)$ & $5(5)$ & $1(13)$ & $7(10)$ & $6(6)$ & $4(4)$ & $2(2)$ & $9(12)$ & $50(70)$ \\
\hline
\end{tabular}


Table 21. Values used to estimate ingested daily doses of selenium by Black-necked Stilts (DIBNST) and hazard quotients (HQ) for predictive ecological risk assessment; Ecosystem Monitoring Project, Salton Sea, California, fall 2006-fall 2008.

[Exposure values: Ci, average dry weight selenium concentration in Corixidae from each site; Rd, daily dietary intake rate for stilts (mg/d, dw); Fi, fraction of invertebrates in stilt diet; ECs, average dry weight selenium concentration in sediments from each site; Fs, fraction of sediment in stilt diet; BWBNS, average stilt body weight; Tf, fraction of time spent at site. See appendix 11 for rationale behind selected exposure values]

\begin{tabular}{|c|c|c|c|c|c|c|c|c|c|c|c|}
\hline \multirow[b]{2}{*}{ Group } & \multirow[b]{2}{*}{ Site } & \multicolumn{7}{|c|}{ Exposure values } & \multirow[b]{2}{*}{ DIBNST } & \multirow[b]{2}{*}{ HQ(low) } & \multirow{2}{*}{$\begin{array}{c}\text { HQ } \\
\text { (high) }\end{array}$} \\
\hline & & $\mathrm{Ci}$ & Rd & $\mathbf{F i}$ & ECs & Fs & BWBNST & Tf & & & \\
\hline \multirow[t]{5}{*}{ SHP } & Pond 1 & 5.20 & 14.219 & 0.949 & 1.80 & 0.16 & 169.6 & 1.0 & 0.44 & 1.90 & 0.47 \\
\hline & Pond 2 & 5.15 & 14.219 & 0.949 & 1.33 & 0.16 & 169.6 & 1.0 & 0.43 & 1.86 & 0.46 \\
\hline & Pond 3 & 4.81 & 14.219 & 0.949 & 2.29 & 0.16 & 169.6 & 1.0 & 0.41 & 1.80 & 0.44 \\
\hline & Pond 4 & 3.51 & 14.219 & 0.949 & 1.95 & 0.16 & 169.6 & 1.0 & 0.31 & 1.33 & 0.33 \\
\hline & All SHP & 4.96 & 14.219 & 0.949 & 1.84 & 0.16 & 169.6 & 1.0 & 0.42 & 1.82 & 0.45 \\
\hline \multirow[t]{4}{*}{ Reference } & $\begin{array}{l}\text { Salton Sea } \\
\text { D- }\end{array}$ & 2.93 & 14.219 & 0.949 & 1.82 & 0.16 & 169.6 & 1.0 & 0.26 & 1.12 & 0.28 \\
\hline & $\begin{array}{l}\text { Pond/Hazard } \\
\text { Freshwater }\end{array}$ & 1.70 & 14.219 & 0.949 & 0.49 & 0.16 & 169.6 & 1.0 & 0.14 & 0.62 & 0.15 \\
\hline & Marsh & 2.50 & 14.219 & 0.949 & 2.16 & 0.16 & 169.6 & 1.0 & 0.23 & 0.99 & 0.25 \\
\hline & All Reference & 2.32 & 14.219 & 0.949 & 1.26 & 0.16 & 169.6 & 1.0 & 0.20 & 0.88 & 0.22 \\
\hline
\end{tabular}




\section{Appendixes}

\section{Appendix 1. EPA methods used by Battelle Marine Sciences Laboratory to analyze concentrations of trace elements $(\mu \mathrm{g} / \mathrm{L})$ in water samples collected from saline habitat ponds (SHP) and reference sites, Ecosystem Monitoring Project, Salton Sea, California, fall 2006-fall 2008.}

[NQ, element not quantified]

\begin{tabular}{|c|c|c|c|c|c|}
\hline \multirow[b]{2}{*}{ Element } & \multicolumn{5}{|c|}{ Sampling period } \\
\hline & Fall 2006 & Spring 2007 & Fall 2007 & Spring 2008 & Fall 2008 \\
\hline Ag (Silver) & $200.7^{1}$ & 200.7 & 200.7 & 200.7 & 200.7 \\
\hline $\mathrm{Al}$ (Aluminum) & 200.7 & 200.7 & 200.7 & 200.7 & 200.7 \\
\hline As (Arsenic) & 200.7 & 7742 & 200.8 & 7742 & 7742 \\
\hline B (Boron) & 200.7 & 200.7 & 200.7 & 200.7 & 200.7 \\
\hline Ba (Barium) & 200.7 & 200.7 & 200.7 & 200.7 & 200.7 \\
\hline Be (Beryllium ) & 200.7 & 200.7 & 200.7 & 200.7 & 200.7 \\
\hline Cd (Cadmium) & 200.7 & 200.7 & 200.7 & 200.7 & 200.7 \\
\hline Co (Cobalt) & 200.7 & 200.7 & 200.7 & 200.7 & 200.7 \\
\hline Cr (Chromium) & 200.7 & 200.7 & 200.7 & 200.7 & 200.7 \\
\hline $\mathrm{Cu}$ (Copper) & 200.7 & 200.7 & 200.7 & 200.7 & 200.7 \\
\hline Fe (Iron) & 200.7 & 200.7 & 200.7 & 200.7 & 200.7 \\
\hline Hg (Mercury) & 245.5 & NQ & NQ & NQ & NQ \\
\hline Mn (Manganese) & 200.7 & 200.7 & 200.7 & 200.7 & 200.7 \\
\hline Mo (Molybdenum) & 200.7 & 200.7 & 200.7 & 200.7 & 200.7 \\
\hline Ni (Nickel) & 200.7 & 200.7 & 200.7 & 200.7 & 200.7 \\
\hline $\mathrm{Pb}$ (Lead) & 200.7 & 200.7 & 200.8 & 200.7 & 200.7 \\
\hline Sb (Antimony) & 200.7 & 7742 & 200.8 & 7742 & NQ \\
\hline Se (Selenium) & 200.7 & 7742 & 7742 & 7742 & 7742 \\
\hline Sn (Tin) & 200.8 & 200.8 & 200.8 & NQ & NQ \\
\hline Tl (Thallium) & 200.7 & 200.7 & 200.7 & 200.7 & 200.7 \\
\hline V (Vanadium) & 200.7 & 200.7 & 200.7 & 200.7 & 200.7 \\
\hline Zn (Zinc) & 200.7 & 200.7 & 200.7 & 200.7 & 200.7 \\
\hline
\end{tabular}

${ }^{1} 200.7$ = inductively coupled plasma optical emissions spectrometry (ICP-OES); 200.8 = inductively coupled plasma-mass spectrometry (ICP-MS); 7742 = hydride generation atomic absorption - flow injection atomic spectroscopy (HGAA-FIAS); 245.5 = cold vapor atomic fluorescence (CVAF). 
Appendix 2. Dilution factors used analyzing concentrations of trace elements by ICPOES (EPA 200.7) in water samples collected from saline habitat ponds (SHP) and reference sites, Ecosystem Monitoring Project, Salton Sea, California, fall 2006-fall 2008.

\begin{tabular}{|c|c|c|c|c|c|c|}
\hline \multirow[b]{2}{*}{ Group } & \multirow[b]{2}{*}{ Site } & \multicolumn{5}{|c|}{ Sampling period } \\
\hline & & Fall 2006 & Spring 2007 & Fall 2007 & Spring 2008 & Fall 2008 \\
\hline \multirow[t]{4}{*}{ SHP } & Pond 1 & $5 x$ & $5 x$ & $1 \mathrm{x}$ & $5.7 x$ & $5.75 x$ \\
\hline & Pond 2 & $10 \mathrm{x}$ & $5 x$ & $4 \mathrm{x}$ & $11.4 x$ & $11.5 x$ \\
\hline & Pond 3 & $10 x$ & $10 x$ & $10 x$ & $25 x$ & $28.75 x$ \\
\hline & Pond 4 & $40 x$ & 40.0 & $50-100 x$ & $114 x$ & $115 x$ \\
\hline \multirow[t]{4}{*}{ Reference } & Alamo River & $2 \mathrm{x}$ & $2 \mathrm{x}$ & $1 \mathrm{x}$ & $1 \mathrm{x}$ & $1.15 \mathrm{x}$ \\
\hline & Salton Sea & $10 \mathrm{x}$ & $2 \mathrm{x}$ & $5-100 x$ & $2.5-5.7 x$ & $1.15-2.30 x$ \\
\hline & Freshwater & $2 x$ & $2 \mathrm{x}$ & $1 \mathrm{x}$ & $1 \mathrm{x}$ & $115 \mathrm{x}$ \\
\hline & D-Pond ${ }^{1}$ & $2 x$ & $5 x$ & $1 \mathrm{x}$ & $1 \mathrm{x}$ & $1.15 \mathrm{x}$ \\
\hline
\end{tabular}

${ }^{1} \mathrm{D}$-pond was dry in fall 2008, SSNWR Hazard Pond sampled in its place. 


\section{Appendix 3. Analytical limits of detection for concentrations of trace elements $(\mu \mathrm{g} / \mathrm{L})$ in water samples collected from saline habitat ponds (SHP) and reference sites, Ecosystem Monitoring Project, Salton Sea, California, fall 2006-fall 2008.}

[Limit of detection increased accordingly with dilution used due to salinity (see appendix 2) and modified EPA method (see appendix 1). NQ, element not quantified]

\begin{tabular}{|c|c|c|c|c|c|c|c|}
\hline \multirow[b]{2}{*}{ Element } & \multirow[b]{2}{*}{ Group } & \multirow[b]{2}{*}{ Site } & \multicolumn{5}{|c|}{ Sampling period } \\
\hline & & & $\begin{array}{c}\text { Fall } \\
2006\end{array}$ & $\begin{array}{c}\text { Spring } \\
2007 \\
\end{array}$ & $\begin{array}{l}\text { Fall } \\
2007\end{array}$ & $\begin{array}{c}\text { Spring } \\
2008\end{array}$ & $\begin{array}{c}\text { Fall } \\
2008 \\
\end{array}$ \\
\hline \multirow[t]{8}{*}{ Ag (Silver) } & \multirow[t]{4}{*}{ SHP } & Pond 1 & 2.0 & 0.9 & 0.2 & 1.0 & 1.0 \\
\hline & & Pond 2 & 3.9 & 0.9 & 0.7 & 2.0 & 2.0 \\
\hline & & Pond 3 & 3.9 & 3.4 & 1.7 & 5.5 & 4.9 \\
\hline & & Pond 4 & 15.7 & 5.2 & 14.3 & 19.6 & 19.8 \\
\hline & \multirow[t]{4}{*}{ Reference } & Alamo River & 0.8 & 0.3 & 0.2 & 0.2 & 0.2 \\
\hline & & Salton Sea & 3.9 & 0.9 & 6.3 & 0.6 & 0.3 \\
\hline & & Freshwater Marsh & 0.8 & 0.3 & 0.2 & 0.2 & 0.2 \\
\hline & & D-pond ${ }^{1}$ & 0.8 & 0.3 & 0.2 & 0.2 & 0.2 \\
\hline \multirow[t]{8}{*}{$\mathrm{Al}$ (Aluminum) } & \multirow[t]{4}{*}{ SHP } & Pond 1 & 20.4 & 12.7 & 2.5 & 16.4 & 16.6 \\
\hline & & Pond 2 & 40.7 & 12.7 & 10.2 & 32.8 & 33.3 \\
\hline & & Pond 3 & 40.7 & 50.8 & 25.4 & 92.2 & 82.8 \\
\hline & & Pond 4 & 162.8 & 76.2 & 211.7 & 328.3 & 331.2 \\
\hline & \multirow[t]{4}{*}{ Reference } & Alamo River & 8.1 & 5.1 & 2.5 & 2.9 & 3.3 \\
\hline & & Salton Sea & 40.7 & 12.7 & 93.1 & 9.8 & 5.5 \\
\hline & & Freshwater Marsh & 8.1 & 5.1 & 2.5 & 2.9 & 3.3 \\
\hline & & D-pond & 8.1 & 5.1 & 2.5 & 2.9 & 3.3 \\
\hline \multirow[t]{8}{*}{ As (Arsenic) } & \multirow[t]{4}{*}{ SHP } & Pond 1 & 17.5 & 0.0 & 0.0 & 0.0 & 0.0 \\
\hline & & Pond 2 & 34.9 & 0.02 & 0.02 & 0.02 & 0.04 \\
\hline & & Pond 3 & 34.9 & 0.08 & 0.02 & 0.02 & 0.11 \\
\hline & & Pond 4 & 139.6 & 0.14 & 0.02 & 0.02 & 0.21 \\
\hline & \multirow[t]{4}{*}{ Reference } & Alamo River & 7.0 & 0.02 & 0.02 & 0.02 & 0.03 \\
\hline & & Salton Sea & 34.9 & 0.02 & 0.02 & 0.02 & 0.02 \\
\hline & & Freshwater Marsh & 7.0 & 0.07 & 0.02 & 0.02 & 0.02 \\
\hline & & D-pond & 7.0 & 0.0 & 0.0 & 0.0 & 0.0 \\
\hline \multirow[t]{8}{*}{ B (Boron) } & \multirow[t]{4}{*}{ SHP } & Pond 1 & 800.0 & 213.5 & 42.7 & 9.4 & 11.6 \\
\hline & & Pond 2 & $1,600.0$ & 213.5 & 171.0 & 18.8 & 23.4 \\
\hline & & Pond 3 & $1,600.0$ & 854.0 & 427.0 & 47.0 & 58.1 \\
\hline & & Pond 4 & & $1,281.0$ & $3,558.3$ & 188.0 & 232.3 \\
\hline & \multirow[t]{4}{*}{ Reference } & Alamo River & 320.0 & 85.4 & 43.0 & 1.9 & 2.3 \\
\hline & & Salton Sea & $1,600.0$ & 213.5 & $1,566.0$ & 5.6 & 3.9 \\
\hline & & Freshwater Marsh & 320.0 & 85.4 & 43.0 & 1.9 & 2.3 \\
\hline & & D-pond & 320.0 & 85.4 & 43.0 & 1.9 & 2.3 \\
\hline \multirow[t]{8}{*}{ Ba (Barium) } & \multirow[t]{4}{*}{ SHP } & Pond 1 & 0.6 & 0.7 & 0.1 & 0.8 & 0.8 \\
\hline & & Pond 2 & 1.2 & 0.7 & 0.6 & 1.6 & 1.6 \\
\hline & & Pond 3 & 1.2 & 2.8 & 1.4 & 4.4 & 4.0 \\
\hline & & Pond 4 & 4.8 & 4.2 & 11.6 & 15.8 & 16.0 \\
\hline & \multirow[t]{4}{*}{ Reference } & Alamo River & 0.2 & 0.3 & 0.1 & 0.1 & 0.2 \\
\hline & & Salton Sea & 1.2 & 0.7 & 5.1 & 0.5 & 0.3 \\
\hline & & Freshwater Marsh & 0.2 & 0.3 & 0.1 & 0.1 & 0.2 \\
\hline & & D-pond & 0.2 & 0.3 & 0.1 & 0.1 & 0.2 \\
\hline
\end{tabular}




\section{Appendix 3.-Continued}

\begin{tabular}{|c|c|c|c|c|c|c|c|}
\hline \multirow[b]{2}{*}{ Element } & \multirow[b]{2}{*}{ Group } & \multirow[b]{2}{*}{ Site } & \multicolumn{5}{|c|}{ Sampling period } \\
\hline & & & $\begin{array}{c}\text { Fall } \\
2006\end{array}$ & $\begin{array}{c}\text { Spring } \\
2007\end{array}$ & $\begin{array}{c}\text { Fall } \\
2007\end{array}$ & $\begin{array}{c}\text { Spring } \\
2008\end{array}$ & $\begin{array}{l}\text { Fall } \\
2008 \\
\end{array}$ \\
\hline \multirow[t]{8}{*}{ Be (Beryllium ) } & SHP & Pond 1 & 0.4 & 0.3 & 0.1 & 0.3 & 0.3 \\
\hline & & Pond 2 & 0.8 & 0.3 & 0.2 & 0.6 & 0.6 \\
\hline & & Pond 3 & 0.8 & 1.1 & 0.5 & 1.7 & 1.6 \\
\hline & & Pond 4 & 3.3 & 1.6 & 4.6 & 6.2 & 6.3 \\
\hline & Reference & Alamo River & 0.2 & 0.1 & 0.1 & 0.1 & 0.1 \\
\hline & & Salton Sea & 0.8 & 0.3 & 2.0 & 0.2 & 0.1 \\
\hline & & Freshwater Marsh & 0.2 & 0.1 & 0.1 & 0.1 & 0.1 \\
\hline & & D-pond & 0.2 & 0.1 & 0.1 & 0.1 & 0.1 \\
\hline \multirow[t]{8}{*}{ Cd (Cadmium) } & SHP & Pond 1 & 0.5 & 0.8 & 0.2 & 0.9 & 0.9 \\
\hline & & Pond 2 & 1.1 & 0.8 & 0.6 & 1.8 & 1.8 \\
\hline & & Pond 3 & 1.1 & 3.2 & 1.6 & 5.1 & 4.5 \\
\hline & & Pond 4 & 4.2 & 4.7 & 13.2 & 18.0 & 18.2 \\
\hline & Reference & Alamo River & 0.2 & 0.3 & 0.2 & 0.2 & 0.2 \\
\hline & & Salton Sea & 1.1 & 0.8 & 5.8 & 0.5 & 0.3 \\
\hline & & Freshwater Marsh & 0.2 & 0.3 & 0.2 & 0.2 & 0.2 \\
\hline & & D-pond & 0.2 & 0.3 & 0.2 & 0.2 & 0.2 \\
\hline \multirow[t]{8}{*}{ Co (Cobalt) } & SHP & Pond 1 & 0.5 & 1.3 & 0.3 & 1.5 & 1.5 \\
\hline & & Pond 2 & 1.0 & 1.3 & 1.0 & 2.9 & 3.0 \\
\hline & & Pond 3 & 1.0 & 5.1 & 2.6 & 8.2 & 7.4 \\
\hline & & Pond 4 & 4.2 & 7.7 & 21.3 & 29.2 & 29.4 \\
\hline & Reference & Alamo River & 0.2 & 0.5 & 0.3 & 0.3 & 0.3 \\
\hline & & Salton Sea & 1.0 & 1.3 & 9.4 & 0.9 & 0.5 \\
\hline & & Freshwater Marsh & 0.2 & 0.5 & 0.3 & 0.3 & 0.3 \\
\hline & & D-pond & 0.2 & 0.5 & 0.3 & 0.3 & 0.3 \\
\hline \multirow[t]{8}{*}{ Cr (Chromium) } & SHP & Pond 1 & 0.7 & 1.0 & 0.2 & 1.2 & 1.2 \\
\hline & & Pond 2 & 1.4 & 1.0 & 0.8 & 2.3 & 2.3 \\
\hline & & Pond 3 & 1.4 & 4.1 & 2.0 & 6.5 & 5.8 \\
\hline & & Pond 4 & 5.4 & 6.1 & 16.9 & 23.1 & 23.3 \\
\hline & Reference & Alamo River & 0.3 & 0.4 & 0.2 & 0.2 & 0.2 \\
\hline & & Salton Sea & 1.4 & 1.0 & 7.4 & 0.7 & 0.4 \\
\hline & & Freshwater Marsh & 0.3 & 0.4 & 0.2 & 0.2 & 0.2 \\
\hline & & D-pond & 0.3 & 0.4 & 0.2 & 0.2 & 0.2 \\
\hline \multirow[t]{8}{*}{ Cu (Copper) } & SHP & Pond 1 & 1.6 & 1.2 & 0.2 & 1.3 & 1.3 \\
\hline & & Pond 2 & 3.2 & 1.2 & 0.9 & 2.7 & 2.7 \\
\hline & & Pond 3 & 3.2 & 4.7 & 2.3 & 7.5 & 6.7 \\
\hline & & Pond 4 & 12.7 & 7.0 & 19.4 & 26.6 & 26.8 \\
\hline & Reference & Alamo River & 0.6 & 0.5 & 0.2 & 0.2 & 0.3 \\
\hline & & Salton Sea & 3.2 & 1.2 & 8.5 & 0.8 & 0.4 \\
\hline & & Freshwater Marsh & 0.6 & 0.5 & 0.2 & 0.2 & 0.3 \\
\hline & & D-pond & 0.6 & 0.5 & 0.2 & 0.2 & 0.3 \\
\hline
\end{tabular}




\section{Appendix 3.-Continued}

\begin{tabular}{|c|c|c|c|c|c|c|c|}
\hline \multirow[b]{2}{*}{ Element } & \multirow[b]{2}{*}{ Group } & \multirow[b]{2}{*}{ Sit } & \multicolumn{5}{|c|}{ Sampling period } \\
\hline & & & $\begin{array}{l}\text { Fall } \\
2006\end{array}$ & $\begin{array}{c}\text { Spring } \\
2007\end{array}$ & $\begin{array}{c}\text { Fall } \\
2007 \\
\end{array}$ & $\begin{array}{c}\text { Spring } \\
2008\end{array}$ & $\begin{array}{l}\text { Fall } \\
2008 \\
\end{array}$ \\
\hline \multirow[t]{8}{*}{ Fe (Iron) } & \multirow[t]{4}{*}{ SHP } & Pond 1 & 5.0 & 5.9 & 1.2 & 5.9 & 6.8 \\
\hline & & Pond 2 & 10.0 & 5.9 & 4.7 & 13.5 & 13.6 \\
\hline & & Pond 3 & 10.0 & 23.6 & 11.8 & 37.8 & 33.9 \\
\hline & & Pond 4 & 40.0 & 35.4 & 98.3 & 134.5 & 135.7 \\
\hline & \multirow[t]{4}{*}{ Reference } & Alamo River & 2.0 & 2.4 & 1.2 & 1.2 & 1.4 \\
\hline & & Salton Sea & 10.0 & 5.9 & 43.3 & 3.8 & 2.3 \\
\hline & & Freshwater Marsh & 2.0 & 2.4 & 1.2 & 1.2 & 1.4 \\
\hline & & D-pond & 2.0 & 2.4 & 1.2 & 1.2 & 1.4 \\
\hline \multirow[t]{8}{*}{ Hg (Mercury) } & \multirow[t]{4}{*}{ SHP } & Pond 1 & 0.0001 & NQ & NQ & NQ & NQ \\
\hline & & Pond 2 & 0.0001 & NQ & NQ & NQ & NQ \\
\hline & & Pond 3 & 0.0001 & NQ & NQ & NQ & NQ \\
\hline & & Pond 4 & 0.0001 & NQ & NQ & NQ & NQ \\
\hline & \multirow[t]{4}{*}{ Reference } & Alamo River & 0.0001 & NQ & NQ & NQ & NQ \\
\hline & & Salton Sea & 0.0001 & NQ & NQ & NQ & NQ \\
\hline & & Freshwater Marsh & 0.0001 & NQ & NQ & NQ & NQ \\
\hline & & D-pond & 0.0001 & NQ & NQ & NQ & NQ \\
\hline \multirow[t]{8}{*}{ Mn (Manganese) } & \multirow[t]{4}{*}{ SHP } & Pond 1 & 0.42 & 0.18 & 0.04 & 0.20 & 0.21 \\
\hline & & Pond 2 & 0.84 & 0.18 & 0.14 & 0.41 & 0.41 \\
\hline & & Pond 3 & 0.84 & 0.72 & 0.36 & 1.15 & 1.03 \\
\hline & & Pond 4 & 3.36 & 1.07 & 2.98 & 4.08 & 4.12 \\
\hline & \multirow[t]{4}{*}{ Reference } & Alamo River & 0.17 & 0.07 & 0.04 & 0.04 & 0.04 \\
\hline & & Salton Sea & 0.84 & 0.18 & 1.31 & 0.12 & 0.07 \\
\hline & & Freshwater Marsh & 0.17 & 0.07 & 0.04 & 0.04 & 0.04 \\
\hline & & D-pond & 0.17 & 0.07 & 0.04 & 0.04 & 0.04 \\
\hline \multirow[t]{8}{*}{$\begin{array}{l}\text { Mo } \\
\text { (Molybdenum) }\end{array}$} & \multirow[t]{4}{*}{ SHP } & Pond 1 & 1.6 & 4.2 & 0.8 & 4.6 & 4.7 \\
\hline & & Pond 2 & 3.3 & 4.2 & 3.3 & 9.3 & 9.4 \\
\hline & & Pond 3 & 3.3 & 16.6 & 8.3 & 26.1 & 23.4 \\
\hline & & Pond 4 & 13.1 & 24.9 & 69.3 & 92.9 & 93.7 \\
\hline & \multirow[t]{4}{*}{ Reference } & Alamo River & 0.7 & 1.7 & 0.8 & 0.8 & 0.9 \\
\hline & & Salton Sea & 3.3 & 4.2 & 30.5 & 2.8 & 1.6 \\
\hline & & Freshwater Marsh & 0.7 & 1.7 & 0.8 & 0.8 & 0.9 \\
\hline & & D-pond & 0.7 & 1.7 & 0.8 & 0.8 & 0.9 \\
\hline \multirow[t]{8}{*}{ Ni (Nickel) } & \multirow[t]{4}{*}{ SHP } & Pond 1 & 2.0 & 2.1 & 0.4 & 2.4 & 2.4 \\
\hline & & Pond 2 & 3.9 & 2.1 & 1.7 & 4.7 & 4.8 \\
\hline & & Pond 3 & 3.9 & 8.3 & 4.1 & 13.2 & 11.9 \\
\hline & & Pond 4 & 15.6 & 12.4 & 34.5 & 47.2 & 47.6 \\
\hline & \multirow[t]{4}{*}{ Reference } & Alamo River & 0.78 & 0.83 & 0.41 & 0.41 & 0.48 \\
\hline & & Salton Sea & 3.91 & 2.07 & 15.18 & 1.42 & 0.79 \\
\hline & & Freshwater Marsh & 0.78 & 0.83 & 0.41 & 0.41 & 0.48 \\
\hline & & D-pond & 0.78 & 0.83 & 0.41 & 0.41 & 0.48 \\
\hline
\end{tabular}




\section{Appendix 3.-Continued}

\begin{tabular}{|c|c|c|c|c|c|c|c|}
\hline \multirow[b]{2}{*}{ Element } & \multirow[b]{2}{*}{ Group } & \multirow[b]{2}{*}{ Site } & \multicolumn{5}{|c|}{ Sampling period } \\
\hline & & & $\begin{array}{c}\text { Fall } \\
2006 \\
\end{array}$ & $\begin{array}{c}\text { Spring } \\
2007 \\
\end{array}$ & $\begin{array}{c}\text { Fall } \\
2007 \\
\end{array}$ & $\begin{array}{c}\text { Spring } \\
2008 \\
\end{array}$ & $\begin{array}{c}\text { Fall } \\
2008 \\
\end{array}$ \\
\hline \multirow[t]{8}{*}{ Pb (Lead) } & \multirow[t]{4}{*}{ SHP } & Pond 1 & 9.9 & 7.7 & 0.0 & 11.4 & 11.5 \\
\hline & & Pond 2 & 19.7 & 7.7 & 0.0 & 22.8 & 23.1 \\
\hline & & Pond 3 & 19.7 & 30.6 & 0.0 & 64.0 & 57.5 \\
\hline & & Pond 4 & 78.8 & 45.9 & 0.0 & 228.0 & 230.0 \\
\hline & \multirow[t]{4}{*}{ Reference } & Alamo River & 3.9 & 3.1 & 0.0 & 2.0 & 2.3 \\
\hline & & Salton Sea & 19.7 & 7.7 & 0.0 & 6.8 & 3.8 \\
\hline & & Freshwater Marsh & 3.9 & 3.1 & 0.0 & 2.0 & 2.3 \\
\hline & & D-pond & 3.9 & 3.1 & 0.0 & 2.0 & 2.3 \\
\hline \multirow[t]{8}{*}{ Sb (Antimony) } & \multirow[t]{4}{*}{ SHP } & Pond 1 & 18.2 & 0.1 & 0.0 & 0.1 & NQ \\
\hline & & Pond 2 & 36.3 & 0.1 & 0.0 & 0.1 & NQ \\
\hline & & Pond 3 & 36.3 & 0.2 & 0.0 & 0.1 & NQ \\
\hline & & Pond 4 & 145.0 & 0.4 & 0.0 & 0.1 & NQ \\
\hline & \multirow[t]{4}{*}{ Reference } & Alamo River & 7.3 & 0.1 & 0.0 & 0.1 & NQ \\
\hline & & Salton Sea & 36.3 & 0.1 & 0.0 & 0.1 & NQ \\
\hline & & Freshwater Marsh & 7.3 & 0.1 & 0.0 & 0.1 & NQ \\
\hline & & D-pond & 7.3 & 0.1 & 0.0 & 0.1 & NQ \\
\hline \multirow[t]{8}{*}{ Se (Selenium) } & \multirow[t]{4}{*}{ SHP } & Pond 1 & 0.08 & 0.08 & 0.08 & 0.07 & 0.07 \\
\hline & & Pond 2 & 0.08 & 0.08 & 0.30 & 0.07 & 0.13 \\
\hline & & Pond 3 & 0.08 & 0.18 & 0.76 & 0.07 & 0.34 \\
\hline & & Pond 4 & 0.08 & 0.28 & 3.90 & 0.07 & 0.67 \\
\hline & \multirow[t]{4}{*}{ Reference } & Alamo River & 0.08 & 0.08 & 0.08 & 0.07 & 0.09 \\
\hline & & Salton Sea & 0.08 & 0.08 & 1.57 & 0.07 & 0.07 \\
\hline & & Freshwater Marsh & 0.08 & 0.08 & 0.08 & 0.07 & 0.07 \\
\hline & & D-pond & 0.08 & 0.08 & 0.08 & 0.07 & 0.07 \\
\hline \multirow[t]{8}{*}{ Sn (Tin) } & \multirow[t]{4}{*}{ SHP } & Pond 1 & 0.10 & 0.06 & 0.10 & NQ & NQ \\
\hline & & Pond 2 & 0.10 & 0.06 & 0.10 & NQ & NQ \\
\hline & & Pond 3 & 0.10 & 0.06 & 0.10 & NQ & NQ \\
\hline & & Pond 4 & 0.10 & 0.06 & 0.10 & NQ & NQ \\
\hline & \multirow[t]{4}{*}{ Reference } & Alamo River & 0.10 & 0.06 & 0.10 & NQ & NQ \\
\hline & & Salton Sea & 0.10 & 0.06 & 0.10 & NQ & NQ \\
\hline & & Freshwater Marsh & 0.10 & 0.06 & 0.10 & NQ & NQ \\
\hline & & D-pond & 0.10 & 0.06 & 0.10 & NQ & NQ \\
\hline \multirow[t]{8}{*}{ Tl (Thallium) } & \multirow[t]{4}{*}{ SHP } & Pond 1 & 25.0 & 11.1 & 2.2 & 12.7 & 12.8 \\
\hline & & Pond 2 & 50.0 & 11.1 & 8.9 & 25.3 & 25.7 \\
\hline & & Pond 3 & 50.0 & 44.4 & 22.2 & 71.0 & 63.8 \\
\hline & & Pond 4 & 200.0 & 66.6 & 185.0 & 253.1 & 255.3 \\
\hline & \multirow[t]{4}{*}{ Reference } & Alamo River & 10.0 & 4.4 & 2.2 & 2.2 & 2.6 \\
\hline & & Salton Sea & 50.0 & 11.1 & 81.4 & 7.6 & 4.3 \\
\hline & & Freshwater Marsh & 10.0 & 4.4 & 2.2 & 2.2 & 2.6 \\
\hline & & D-pond & 10.0 & 4.4 & 2.2 & 2.2 & 2.6 \\
\hline \multirow[t]{4}{*}{ V (Vanadium) } & \multirow[t]{4}{*}{ SHP } & Pond 1 & 1.1 & 1.4 & 0.3 & 1.6 & 1.6 \\
\hline & & Pond 2 & 2.1 & 1.4 & 1.1 & 3.1 & 3.2 \\
\hline & & Pond 3 & 2.1 & 5.5 & 2.8 & 8.8 & 7.9 \\
\hline & & Pond 4 & 8.4 & 8.3 & 23.0 & 31.5 & 31.7 \\
\hline
\end{tabular}




\section{Appendix 3.-Continued}

\begin{tabular}{|c|c|c|c|c|c|c|c|}
\hline \multirow[b]{2}{*}{ Element } & \multirow[b]{2}{*}{ Group } & \multirow[b]{2}{*}{ Site } & \multicolumn{5}{|c|}{ Sampling period } \\
\hline & & & $\begin{array}{c}\text { Fall } \\
2006 \\
\end{array}$ & $\begin{array}{c}\text { Spring } \\
2007\end{array}$ & $\begin{array}{l}\text { Fall } \\
2007\end{array}$ & $\begin{array}{c}\text { Spring } \\
2008 \\
\end{array}$ & $\begin{array}{r}\text { Fall } \\
2008 \\
\end{array}$ \\
\hline \multirow[t]{4}{*}{ V (Vanadium) } & Reference & Alamo River & 0.4 & 0.6 & 0.3 & 0.3 & 0.3 \\
\hline & & Salton Sea & 2.1 & 1.4 & 10.1 & 0.9 & 0.5 \\
\hline & & Freshwater Marsh & 0.4 & 0.6 & 0.3 & 0.3 & 0.3 \\
\hline & & D-pond & 0.4 & 0.6 & 0.3 & 0.3 & 0.3 \\
\hline \multirow[t]{8}{*}{ Zn (Zinc) } & SHP & Pond 1 & 17.4 & 0.6 & 0.1 & 0.7 & 0.7 \\
\hline & & Pond 2 & 42.7 & 0.6 & 0.5 & 1.3 & 1.4 \\
\hline & & Pond 3 & 45.1 & 2.3 & 1.2 & 3.7 & 3.4 \\
\hline & & Pond 4 & 198.3 & 3.5 & 9.8 & 13.3 & 13.5 \\
\hline & Reference & Alamo River & 10.3 & 0.2 & 0.1 & 0.1 & 0.1 \\
\hline & & Salton Sea & 54.3 & 0.6 & 4.3 & 0.4 & 0.2 \\
\hline & & Freshwater Marsh & 6.8 & 0.2 & 0.1 & 0.1 & 0.1 \\
\hline & & D-pond & 7.9 & 0.2 & 0.1 & 0.1 & 0.1 \\
\hline
\end{tabular}

${ }^{1}$ D-pond was dry in fall 2008, Hazard Pond sampled in its place. 


\section{Appendix 4. Limits of detection ( $\mathrm{mg} / \mathrm{L})$ for organochlorine compounds in surface-water samples, Ecosystem Monitoring Project, Salton Sea, California, fall 2006-fall 2008.}

[Sampling period: Spring 2008 was not sampled. NQ, analyte not quantified]

\begin{tabular}{lllllr}
\hline & & \multicolumn{4}{c}{ Sampling period } \\
\cline { 3 - 6 } $\begin{array}{c}\text { Organochlorine } \\
\text { group }\end{array}$ & \multicolumn{1}{c}{ Compound } & Fall & Spring & Fall & Fall \\
\hline DDT & $p, p^{\prime}$ DDD & 0.00010 & 0.00010 & 0.00005 & 0.00001 \\
& $p, p^{\prime}$ DDE & 0.00010 & 0.00010 & 0.00005 & 0.00001 \\
& $p, p^{\prime}$ DDT & 0.00010 & 0.00010 & 0.00005 & 0.00001 \\
& o,p DDD & 0.00010 & 0.00010 & 0.00005 & 0.00001 \\
& o,p' DDE & 0.00010 & 0.00010 & 0.00005 & 0.00001 \\
Chlordane & o,p' DDT & 0.00010 & 0.00010 & 0.00005 & 0.00001 \\
& alpha chlordane & 0.00010 & 0.00010 & 0.00005 & 0.00001 \\
& gamma chlordane & 0.00010 & 0.00010 & 0.00005 & 0.00001 \\
& oxychlordane & 0.00010 & 0.00010 & 0.00005 & 0.00001 \\
& cis-nonachlor & 0.00010 & 0.00010 & 0.00005 & 0.00001 \\
trans-nonachlor & 0.00010 & 0.00010 & 0.00005 & 0.00001 \\
Hexachloro- & heptachlor & & & & \\
cyclohexane & epoxide & 0.00010 & 0.00010 & 0.00005 & 0.00001 \\
& alpha BHC & 0.00010 & 0.00010 & 0.00005 & 0.00001 \\
& beta BHC & 0.00010 & 0.00010 & 0.00005 & 0.00001 \\
Drin & delta BHC & 0.00010 & 0.00010 & NQ & NQ \\
& gamma BHC & 0.00010 & 0.00010 & 0.00005 & 0.00001 \\
PCB & dieldrin & 0.00010 & 0.00010 & 0.00005 & 0.00001 \\
Chlorobenzenes & endrin & 0.00010 & 0.00010 & 0.00005 & 0.00001 \\
Other & PCB-TOTAL & 0.00010 & 0.00050 & 0.00025 & 0.00005 \\
& HCB & 0.00010 & 0.00010 & 0.00005 & 0.00001 \\
& mirex & 0.00010 & 0.00010 & 0.00005 & 0.00001 \\
& toxaphene & 0.00010 & 0.00250 & 0.00100 & 0.00025 \\
\hline
\end{tabular}


Appendix 5. Analytical limits of detection ( $\mu \mathrm{g} / \mathrm{g}$, dry weight) and modified EPA methods used by Battelle Marine Sciences Laboratory (in parentheses) for concentrations of trace elements in sediment samples collected from saline habitat ponds (SHP) and reference sites, Ecosystem Monitoring Project, Salton Sea, California, spring 2006-fall 2008.

[NQ, element not quantified]

\begin{tabular}{|c|c|c|c|c|c|c|}
\hline \multirow[b]{2}{*}{ Eement } & \multicolumn{6}{|c|}{ Sampling period } \\
\hline & Spring 2006 & Fall 2006 & Spring 2007 & Fall 2007 & Spring 2008 & Fall 2008 \\
\hline Ag (Silver) & $0.22(200.7)^{1}$ & $0.026(200.7)$ & $0.0327(200.7)$ & $0.006(200.8)$ & $0.0134(200.7)$ & $0.0134(200.7)$ \\
\hline $\mathrm{Al}$ (Aluminum) & $2.28(200.7)$ & $2.03(200.7)$ & $2.03(200.7)$ & $2.03(200.7)$ & 2.66 (200.7) & 0.87 (200.7) \\
\hline As (Arsenic) & $1.95(200.7)$ & $0.282(200.7)$ & $0.02(200.8)$ & $0.564(200.7)$ & $0.218(200.7)$ & $0.218(200.7)$ \\
\hline B (Boron) & $0.551(200.8)$ & $3.62(200.8)$ & $3.62(200.8)$ & $3.62(200.8)$ & $0.212(200.7)$ & $0.212(200.7)$ \\
\hline Ba (Barium) & $0.067(200.7)$ & $0.111(200.7)$ & $0.111(200.7)$ & $0.111(200.7)$ & $0.0614(200.7)$ & $0.0614(200.7)$ \\
\hline Be (Beryllium ) & $0.046(200.7)$ & $0.021(200.7)$ & $0.021(200.7)$ & 0.0437 (200.7) & 0.0378 (200.7) & 0.0378 (200.7) \\
\hline Cd (Cadmium) & $0.0594(200.7)$ & $0.004(200.8)$ & $0.0295(200.7)$ & $0.0542(200.7)$ & $0.0139(200.7)$ & $0.0139(200.7)$ \\
\hline Co (Cobalt) & 0.019 (200.8) & $0.0023(200.8)$ & $0.0023(200.8)$ & $0.2(200.7)$ & $0.0203(200.7)$ & $0.0203(200.7)$ \\
\hline Cr (Chromium) & $0.076(200.7)$ & $0.162(200.7)$ & $0.162(200.7)$ & $0.162(200.7)$ & $0.137(200.7)$ & $0.137(200.7)$ \\
\hline Cu (Copper) & $0.178(200.7)$ & $0.186(200.7)$ & $0.186(200.7)$ & $0.186(200.7)$ & $0.0577(200.7)$ & $0.0577(200.7)$ \\
\hline Fe (Iron) & $0.385(200.7)$ & $0.944(200.7)$ & $0.944(200.7)$ & $0.944(200.7)$ & $0.638(200.7)$ & $0.638(200.7)$ \\
\hline Hg (Mercury) & $0.003(245.5)$ & NQ & NQ & NQ & NQ & NQ \\
\hline Mn (Manganese) & $0.047(200.7)$ & $0.0286(200.7)$ & $0.0286(200.7)$ & $0.0286(200.7)$ & $0.0165(200.7)$ & $0.022(200.7)$ \\
\hline Mo (Molybdenum) & $0.0602(200.7)$ & $0.06(200.7)$ & $0.052(200.7)$ & $0.12(200.7)$ & $0.0253(200.7)$ & $0.0253(200.7)$ \\
\hline Ni (Nickel) & $0.219(200.7)$ & $0.331(200.7)$ & $0.331(200.7)$ & $0.331(200.7)$ & $0.14(200.7)$ & $0.14(200.7)$ \\
\hline $\mathrm{Pb}$ (Lead) & $1.1(200.7)$ & $1.22(200.7)$ & $1.22(200.7)$ & $1.22(200.7)$ & $0.759(200.7)$ & $0.759(200.7)$ \\
\hline Sb (Antimony) & $0.668(200.7)$ & $0.1(200.8)$ & $0.405(200.7)$ & $0.018(200.8)$ & NQ & NQ \\
\hline Se (Selenium) & $1.04(200.7)$ & $0.00838(7742)$ & 0.00838 (7742) & $0.00838(7742)$ & 0.0232 (7742) & 0.005 (7742) \\
\hline Sn (Tin) & $0.049(200.8)$ & $0.1(200.8)$ & 0.009 (200.8) & $0.1(200.8)$ & NQ & NQ \\
\hline Tl (Thallium) & $0.362(200.7)$ & $0.0027(200.8)$ & $0.0027(200.8)$ & $0.0027(200.8)$ & NQ & NQ \\
\hline V (Vanadium) & $0.117(200.7)$ & $0.221(200.7)$ & $0.221(200.7)$ & $0.221(200.7)$ & $0.258(200.7)$ & $0.202(200.7)$ \\
\hline Zn (Zinc) & $0.108(200.7)$ & $0.0936(200.7)$ & $0.0936(200.7)$ & $0.0936(200.7)$ & $0.0558(200.7)$ & $0.0558(200.7)$ \\
\hline
\end{tabular}

${ }^{1} 200.7$ = inductively coupled plasma optical emissions spectrometry (ICP-OES); 200.8 = inductively coupled plasma-mass spectrometry (ICP-MS); 7742 = hydride generation atomic absorption - flow injection atomic spectroscopy (HGAA-FIAS); 245.5= cold vapor atomic fluorescence (CVAF). 


\section{Appendix 6. Limits of detection ( $\mu \mathrm{g} / \mathrm{g}$, dry weight) for organochlorine compounds in sediment samples, Ecosystem Monitoring Project, Salton Sea, California, spring 2006-fall 2008.}

[Sampling period: Spring 2008 samples were not analyzed for non-DDT compounds. NQ, compound not quantified]

\begin{tabular}{|c|c|c|c|c|c|c|}
\hline \multirow[b]{2}{*}{$\begin{array}{l}\text { Organochlorine } \\
\text { group }\end{array}$} & \multirow[b]{2}{*}{ Compound } & \multicolumn{5}{|c|}{ Sampling period } \\
\hline & & $\begin{array}{l}\text { Spring } \\
2006\end{array}$ & $\begin{array}{l}\text { Spring } \\
2007\end{array}$ & $\begin{array}{l}\text { Fall } \\
2007\end{array}$ & $\begin{array}{c}\text { Spring } \\
2008\end{array}$ & $\begin{array}{l}\text { Fall } \\
2008\end{array}$ \\
\hline \multirow[t]{6}{*}{ DDT } & $p, p^{\prime} \mathrm{DDD}$ & 0.002 & 0.002 & 0.002 & 0.002 & 0.002 \\
\hline & $p, p^{\prime} \mathrm{DDE}$ & 0.002 & 0.002 & 0.002 & 0.002 & 0.002 \\
\hline & $p, p^{\prime} \mathrm{DDT}$ & 0.002 & 0.002 & 0.002 & 0.002 & 0.002 \\
\hline & $o, p^{\prime} \mathrm{DDD}$ & 0.002 & 0.002 & 0.002 & 0.002 & 0.002 \\
\hline & $o, p^{\prime} \mathrm{DDE}$ & 0.002 & 0.002 & 0.002 & 0.002 & 0.002 \\
\hline & $o, p^{\prime} \mathrm{DDT}$ & 0.002 & 0.002 & 0.002 & 0.002 & 0.002 \\
\hline \multirow[t]{6}{*}{ Chlordane } & alpha chlordane & 0.002 & 0.002 & 0.002 & NQ & 0.002 \\
\hline & gamma chlordane & 0.002 & 0.002 & 0.002 & NQ & 0.002 \\
\hline & oxychlordane & 0.002 & 0.002 & 0.002 & NQ & 0.002 \\
\hline & cis-nonachlor & 0.002 & 0.002 & 0.002 & NQ & 0.002 \\
\hline & trans-nonachlor & 0.002 & 0.002 & 0.002 & NQ & 0.002 \\
\hline & heptachlor epoxide & 0.002 & 0.002 & 0.002 & NQ & 0.002 \\
\hline \multirow{4}{*}{$\begin{array}{l}\text { Hexachloro- } \\
\text { cyclohexane }\end{array}$} & alpha BHC & 0.002 & 0.002 & 0.002 & NQ & 0.002 \\
\hline & beta BHC & 0.002 & 0.002 & 0.002 & NQ & 0.002 \\
\hline & delta BHC & 0.002 & 0.002 & 0.002 & NQ & NQ \\
\hline & gamma BHC & 0.002 & 0.002 & 0.002 & NQ & 0.002 \\
\hline \multirow[t]{2}{*}{ Drin } & dieldrin & 0.002 & 0.002 & 0.002 & NQ & 0.002 \\
\hline & endrin & 0.002 & 0.002 & 0.002 & NQ & 0.002 \\
\hline PCB & Total PCBs & 0.010 & 0.010 & 0.010 & NQ & 0.010 \\
\hline Chlorobenzene & HCB & 0.002 & 0.002 & 0.002 & NQ & 0.002 \\
\hline \multirow[t]{2}{*}{ Other } & mirex & 0.002 & 0.002 & 0.002 & NQ & 0.002 \\
\hline & toxaphene & 0.050 & 0.050 & 0.050 & NQ & 0.050 \\
\hline
\end{tabular}


Appendix 7. Analytical limits of detection ( $\mu \mathrm{g} / \mathrm{g}$, dry weight) and modified EPA methods used by Battelle Marine Sciences Laboratory (parentheses) for concentrations of trace elements $(\mu \mathrm{g} / \mathrm{g})$ in invertebrate samples collected from saline habitat ponds (SHP) and reference sites, Ecosystem Monitoring Project, Salton Sea, California, fall 2006-fall 2008.

[NQ, element not quantified]

\begin{tabular}{llllll}
\hline & \multicolumn{5}{c}{ Sampling period } \\
\cline { 2 - 6 } & \multicolumn{1}{c}{ Fall 2006 } & \multicolumn{1}{c}{ Spring 2007 } & \multicolumn{1}{c}{ Fall 2007 } & \multicolumn{1}{c}{ Spring 2008 } & \multicolumn{1}{c}{ Fall 2008 } \\
\hline Ag (Silver) & $0.0387(200.7)$ & $0.0387(200.7)$ & $0.0387(200.7)$ & $0.0377(200.7)$ & $0.0377(200.7)$ \\
Al (Aluminum) & $0.248(200.7)$ & $0.248(200.7)$ & $0.248(200.7)$ & $0.325(200.7)$ & $0.325(200.7)$ \\
As (Arsenic) & $0.189(200.7)$ & $0.189(200.7)$ & $0.1(200.8)$ & $1.28(200.7)$ & $1.28(200.7)$ \\
B (Boron) & $0.551(200.8)$ & $0.551(200.8)$ & $0.551(200.8)$ & $0.126(200.7)$ & $0.126(200.7)$ \\
Ba (Barium) & $0.013(200.7)$ & $0.013(200.7)$ & $0.013(200.7)$ & $0.0192(200.7)$ & $0.0192(200.7)$ \\
Be (Beryllium ) & $0.0034(200.7)$ & $0.0034(200.7)$ & $0.0034(200.7)$ & $0.0046(200.7)$ & $0.0046(200.7)$ \\
Cd (Cadmium) & $0.0077(200.7)$ & $0.0077(200.7)$ & $0.008(200.7)$ & $0.0403(200.7)$ & $0.0403(200.7)$ \\
Co (Cobalt) & $0.0178(200.7)$ & $0.0178(200.7)$ & $0.0178(200.7)$ & $0.0207(200.7)$ & $0.0207(200.7)$ \\
Cr (Chromium) & $0.042(200.7)$ & $0.042(200.7)$ & $0.042(200.7)$ & $0.0362(200.7)$ & $0.0362(200.7)$ \\
Cu (Copper) & $0.050(200.7)$ & $0.050(200.7)$ & $0.050(200.7)$ & $0.0334(200.7)$ & $0.0334(200.7)$ \\
Fe (Iron) & $1.53(200.7)$ & $1.53(200.7)$ & $1.53(200.7)$ & $0.297(200.7)$ & $0.297(200.7)$ \\
Mn (Manganese) & $0.0115(200.7)$ & $0.0115(200.7)$ & $0.0115(200.7)$ & $0.0088(200.7)$ & $0.0088(200.7)$ \\
Mo (Molybdenum) $)$ & $0.0403(200.7)$ & $0.0403(200.7)$ & $0.0403(200.7)$ & $0.0662(200.7)$ & $0.0662(200.7)$ \\
Ni (Nickel) & $0.0217(200.7)$ & $0.0227(200.7)$ & $0.0217(200.7)$ & $0.0617(200.7)$ & $0.0617(200.7)$ \\
Pb (Lead) & $0.138(200.7)$ & $0.138(200.7)$ & $0.138(200.7)$ & $0.273(200.7)$ & $0.273(200.7)$ \\
Sb (Antimony) & $0.165(200.7)$ & $0.165(200.7)$ & $0.0123(200.8)$ & $0.165(200.7)$ & $0.256(200.7)$ \\
Se (Selenium) & $0.194(200.8)$ & $0.194(200.8)$ & $0.194(200.8)$ & $0.0124(7,742)$ & $0.0082(7,472)$ \\
Sn (Tin) & $0.0491(200.8)$ & $0.0491(200.8)$ & $0.0491(200.8)$ & NQ & NQ \\
Tl (Thallium) & $0.200(200.7)$ & $0.200(200.7)$ & $0.0015(200.8)$ & $0.244(200.7)$ & $0.244(200.7)$ \\
V (Vanadium) & $0.034(200.7)$ & $0.034(200.7)$ & $0.034(200.7)$ & $0.0411(200.7)$ & $0.0411(200.7)$ \\
Zn (Zinc) & $0.110(200.7)$ & $0.110(200.7)$ & $0.110(200.7)$ & $0.063(200.7)$ & $0.063(200.7)$ \\
\hline
\end{tabular}

${ }^{1} 200.7$ = inductively coupled plasma optical emissions spectrometry (ICP-OES); 200.8 = inductively coupled plasmamass spectrometry (ICP-MS); 7742 = hydride generation atomic absorption - flow injection atomic spectroscopy (HGAA-FIAS). 


\section{Appendix 8. Limits of detection ( $\mu \mathrm{g} / \mathrm{g}$, wet weight) for organochlorine compounds in invertebrate samples, Ecosystem Monitoring Project, Salton Sea, California, fall 2006-fall 2008.}

[NQ, compound not quantified]

\begin{tabular}{|c|c|c|c|c|c|c|}
\hline \multirow[b]{2}{*}{$\begin{array}{c}\text { Organochlorine } \\
\text { group }\end{array}$} & \multirow[b]{2}{*}{ Compound } & \multicolumn{5}{|c|}{ Sampling period } \\
\hline & & Fall 2006 & $\begin{array}{c}\text { Spring } \\
2007\end{array}$ & Fall 2007 & Spring 2008 & Fall 2008 \\
\hline \multirow[t]{6}{*}{ DDT } & $p, p^{\prime} \mathrm{DDD}$ & 0.002 & 0.002 & 0.002 & 0.002 & 0.002 \\
\hline & $p, p^{\prime} \mathrm{DDE}$ & 0.002 & 0.002 & 0.002 & 0.002 & 0.002 \\
\hline & $p, p^{\prime} \mathrm{DDT}$ & 0.002 & 0.002 & 0.002 & 0.002 & 0.002 \\
\hline & $o, p^{\prime} \mathrm{DDD}$ & 0.002 & 0.002 & 0.002 & 0.002 & 0.002 \\
\hline & $o, p^{\prime} \mathrm{DDE}$ & 0.002 & 0.002 & 0.002 & 0.002 & 0.002 \\
\hline & $o, p^{\prime} \mathrm{DDT}$ & 0.002 & 0.002 & 0.002 & 0.002 & 0.002 \\
\hline \multirow[t]{6}{*}{ Chlordane } & alpha chlordane & 0.002 & 0.002 & 0.002 & NQ & 0.002 \\
\hline & gamma chlordane & 0.002 & 0.002 & 0.002 & NQ & 0.002 \\
\hline & oxychlordane & 0.002 & 0.002 & 0.002 & NQ & 0.002 \\
\hline & cis-nonachlor & 0.002 & 0.002 & 0.002 & NQ & 0.002 \\
\hline & trans-nonachlor & 0.002 & 0.002 & 0.002 & NQ & 0.002 \\
\hline & heptachlor epoxide & 0.002 & 0.002 & 0.002 & NQ & 0.002 \\
\hline \multirow{4}{*}{$\begin{array}{l}\text { Hexachloro- } \\
\text { cyclohexane }\end{array}$} & alpha BHC & 0.002 & 0.002 & 0.002 & NQ & 0.002 \\
\hline & beta BHC & 0.002 & 0.002 & 0.002 & NQ & 0.002 \\
\hline & delta BHC & 0.002 & 0.002 & 0.002 & NQ & NQ \\
\hline & gamma BHC & 0.002 & 0.002 & 0.002 & NQ & 0.002 \\
\hline \multirow[t]{2}{*}{ Drin } & dieldrin & 0.002 & 0.002 & 0.002 & NQ & 0.002 \\
\hline & endrin & 0.002 & 0.002 & 0.002 & NQ & 0.002 \\
\hline PCB & Total PCBs & 0.010 & 0.010 & 0.010 & NQ & 0.010 \\
\hline Chlorobenzene & НCB & 0.002 & 0.002 & 0.002 & NQ & 0.002 \\
\hline \multirow[t]{2}{*}{ Other } & mirex & 0.002 & 0.002 & 0.002 & NQ & 0.002 \\
\hline & toxaphene & 0.050 & 0.050 & 0.050 & NQ & 0.050 \\
\hline
\end{tabular}


Appendix 9. Analytical limits of detection ( $\mu \mathrm{g} / \mathrm{g}$, dry weight) and modified EPA methods used by Battelle Marine Sciences Laboratory (values in parentheses) for concentrations of trace elements (mg/g) in fresh Black-necked Stilt eggs collected from saline habitat ponds (SHP) and reference sites, Ecosystem Monitoring Project, Salton Sea, California, May-July 2006-08.

[NQ, element not quantified]

\begin{tabular}{|c|c|c|c|}
\hline \multirow[b]{2}{*}{ Element } & \multicolumn{3}{|c|}{ Sampling period } \\
\hline & 2006 & 2007 & 2008 \\
\hline Ag (Silver) & $0.0387(200.7)^{1}$ & $0.0387(200.7)$ & $0.0377(200.7)$ \\
\hline Al (Aluminum) & $0.248(200.7)$ & $0.248(200.7)$ & 0.325 (200.7) \\
\hline As (Arsenic) & $0.189(200.7)$ & $0.189(200.7)$ & $1.28(200.7)$ \\
\hline B (Boron) & $0.551(200.8)$ & $0.33(200.8)$ & 0.126 (200.7) \\
\hline Ba (Barium) & $0.013(200.7)$ & $0.013(200.7)$ & $0.0192(200.7)$ \\
\hline Be (Beryllium ) & $0.0034(200.7)$ & $0.0034(200.7)$ & $0.0046(200.7)$ \\
\hline Cd (Cadmium) & $0.0077(200.7)$ & 0.0077 (200.7) & $0.0403(200.7)$ \\
\hline Co (Cobalt) & $0.0178(200.7)$ & 0.0178 (200.7) & $0.0207(200.7)$ \\
\hline Cr (Chromium) & $0.042(200.7)$ & $0.042(200.7)$ & $0.0362(200.7)$ \\
\hline Cu (Copper) & $0.050(200.7)$ & $0.050(200.7)$ & $0.0334(200.7)$ \\
\hline Fe (Iron) & $1.53(200.7)$ & $1.53(200.7)$ & 0.297 (200.7) \\
\hline Mn (Manganese) & $0.0115(200.7)$ & $0.0115(200.7)$ & $0.0088(200.7)$ \\
\hline Mo (Molybdenum) & $0.0403(200.7)$ & $0.0403(200.7)$ & $0.0662(200.7)$ \\
\hline Ni (Nickel) & $0.0217(200.7)$ & 0.0227 (200.7) & $0.0617(200.7)$ \\
\hline $\mathrm{Pb}$ (Lead) & $0.138(200.7)$ & $0.138(200.7)$ & $0.273(200.7)$ \\
\hline Sb (Antimony) & $0.165(200.7)$ & $0.0123(200.8)$ & $0.256(200.7)$ \\
\hline Se (Selenium) & $0.194(200.8)$ & $0.194(200.8)$ & $0.0082(7742)$ \\
\hline Sn (Tin) & $0.0491(200.8)$ & $0.010(200.8)$ & NQ \\
\hline Tl (Thallium) & $0.200(200.7)$ & $0.200(200.7)$ & $0.244(200.7)$ \\
\hline V (Vanadium) & $0.034(200.7)$ & $0.034(200.7)$ & $0.0411(200.7)$ \\
\hline Zn (Zinc) & $0.110(200.7)$ & $0.110(200.7)$ & $0.063(200.7)$ \\
\hline
\end{tabular}

${ }^{1} 200.7$ = inductively coupled plasma optical emissions spectrometry (ICP-OES); 200.8 = inductively coupled plasmamass spectrometry (ICP-MS); 7742 = hydride generation atomic absorption - flow injection atomic spectroscopy (HGAA-FIAS). 


\section{Appendix 10. Limits of detection ( $\mu \mathrm{g} / \mathrm{g}$, wet weight) for organochlorine compounds in fresh Black-necked Stilt eggs, Ecosystem Monitoring Project, Salton Sea, California, May-July 2006-08.}

\begin{tabular}{|c|c|c|c|c|}
\hline \multirow[b]{2}{*}{$\begin{array}{c}\text { Organochlorine } \\
\text { group }\end{array}$} & \multirow[b]{2}{*}{ Compound } & \multicolumn{3}{|c|}{ Sampling period } \\
\hline & & 2006 & 2007 & 2008 \\
\hline \multirow[t]{6}{*}{ DDT } & $p, p^{\prime} \mathrm{DDD}$ & 0.002 & 0.002 & 0.002 \\
\hline & $p, p^{\prime} \mathrm{DDE}$ & 0.002 & 0.002 & 0.002 \\
\hline & $p, p^{\prime} \mathrm{DDT}$ & 0.002 & 0.002 & 0.002 \\
\hline & $o, p^{\prime}$ DDD & 0.002 & 0.002 & 0.002 \\
\hline & $o, p^{\prime} \mathrm{DDE}$ & 0.002 & 0.002 & 0.002 \\
\hline & $o, p^{\prime} \mathrm{DDT}$ & 0.002 & 0.002 & 0.002 \\
\hline \multirow[t]{6}{*}{ Chlordane } & alpha chlordane & 0.002 & 0.002 & 0.002 \\
\hline & gamma chlordane & 0.002 & 0.002 & 0.002 \\
\hline & oxychlordane & 0.002 & 0.002 & 0.002 \\
\hline & cis-nonachlor & 0.002 & 0.002 & 0.002 \\
\hline & trans-nonachlor & 0.002 & 0.002 & 0.002 \\
\hline & heptachlor epoxide & 0.002 & 0.002 & 0.002 \\
\hline \multirow{4}{*}{$\begin{array}{l}\text { Hexachloro- } \\
\text { cyclohexane }\end{array}$} & alpha BHC & 0.002 & 0.002 & 0.002 \\
\hline & beta BHC & 0.002 & 0.002 & 0.002 \\
\hline & delta BHC & 0.002 & 0.002 & 0.002 \\
\hline & gamma BHC & 0.002 & 0.002 & 0.002 \\
\hline \multirow[t]{2}{*}{ Drin } & dieldrin & 0.002 & 0.002 & 0.002 \\
\hline & endrin & 0.002 & 0.002 & 0.002 \\
\hline PCB & Total PCBs & 0.010 & 0.010 & 0.010 \\
\hline Chlorobenzene & HCB & 0.002 & 0.002 & 0.002 \\
\hline \multirow[t]{2}{*}{ Other } & mirex & 0.002 & 0.002 & 0.002 \\
\hline & toxaphene & 0.050 & 0.050 & 0.050 \\
\hline
\end{tabular}




\section{Appendix 11. Predictive Ecological Risk Assessment (PERA)}

The PERA is a process of comparing measured concentrations of toxic chemicals with contaminant-specific toxicity data to derive levels that are protective of biota. The result of this process is a hazard quotient (HQ) and/or hazard index (HI) that is generated for each species of concern. For the Salton Sea Ecosystem Monitoring project, the PERA is used to evaluate the potential risk of selenium to aquatic invertebrate-consuming shorebirds. For the purposes of the PERA, exposure pathways are defined as having the following elements

a. A source and mechanism for the release of contaminant(s)

b. Affected medium (or media) that retains or transports contaminants and is accessible to biota

c. Biological receptor(s) present

d. Feasible route of exposure

The PERA is based on the following assumptions and constraints

a. Current chemical concentrations are present at a steady state and will not change over time.

b. The media of primary ecological concern are sediments within $5 \mathrm{~cm}$ of the ground surface, surface water shallower than 1-meter, and also, biological prey.

c. Chemicals not detected are not present, assuming appropriate detection limits.

d. The toxicological information used represents information currently available from literature and database searches.

e. Aquatic organisms are exposed to contaminants via ingestion or direct contact with surface water or sediment.

\section{ASSESSMENT ENDPOINTS}

\section{Ecological Relevance}

The Black-necked Stilt (Himantopus mexicanus) was selected as the assessment endpoint because it is directly tied to the structure and function of the ecosystem at risk. The structure and function of the ecosystem at risk influence the degree and rate of its recovery. Ecologically relevant criteria include

a. Upper-trophic-level species

b. Important prey species

c. Species important to ecosystem structure and function

d. Species with high potential for exposure

e. Species susceptible to bioaccumulation or biomagnification 


\section{Toxicological Relevance}

The black-necked stilt was selected to determine risks to receptors or habitat from contaminants that were measured using existing data. Assessment endpoints are designed to protect populations of vertebrate wildlife, particularly wide-ranging species and their prey, and the important habitat of Salton Sea, including lower trophic terrestrial and aquatic plants and invertebrates from acute (that is, mortality) or chronic (for example, reproductive, growth, or behavioral impairment).

\section{Measurement of Endpoints}

For the Salton Sea Ecosystem Monitoring project PERA, measurement endpoints include evidence of chronic effects such as reproductive, morphological, or physiological impairment in blacknecked stilts. Literature-derived no-observable-adverse-effect levels or NOAELs were used to measure the potential for these adverse chronic effects to occur from direct and secondary exposure to site-related selenium. Field observations and measurements provided a weight-ofevidence approach to qualitatively assess measurement endpoints during this risk assessment.

\section{QUANTITATIVE RISK ASSESSMENT FOR BIOTA}

Functional groupings and representative species at the Salton Sea

The black-necked stilt (aquatic invertebrate consuming shorebird) was selected for the PERA's toxicity evaluations. The criteria for this selection included:

- Species considered essential to or indicative of healthy functioning ecosystems

- Species vital to the structure and function of the food web (for example, principal prey or toptrophic-level predators)

- Species that are representative of entire guilds

- Species for which toxicological data are available in the literature

- Species for which completed exposure pathways can be developed

- Species considered sensitive or of special status by federal or state regulatory agencies or that can be considered surrogates for these species

\section{Exposure pathways}

An exposure pathway is the means by which a representative species comes into contact with and ingests, inhales, or absorbs contaminants of ecological concern (COECs). A complete exposure pathway must include the four elements listed in section 1.2. If any of the four elements are determined to be absent, the pathway is considered incomplete. The only exception is that a transport mechanism may be absent, and the pathway is still considered complete if the ecological receptor is in direct contact with the release point of the COEC. Exposure of ecological receptors to COECs may be direct (that is, primary pathway) or indirect (that is, secondary pathway, for example, exposure through prey). 
Ingestion is the primary route of exposure that will be evaluated for stilts. Inhalation and dermal routes of exposure are assumed to be negligible for aquatic birds and will not be assessed. Pathways of exposure that estimate the quantities of chemicals in contact with stilts include:

\section{Food Webs}

COECs may be transferred through ingestion of affected prey. Receptors, with the exception of primary producers, may be exposed to COECs through the consumption of contaminated food items. Black-necked stilts may be exposed to chemicals accumulated by prey species (for example, aquatic invertebrates). Receptors may also ingest sediment suspended in the water column while drinking surface waters, but this pathway is considered minimal because of the duration of exposure. Lower-trophic-level aquatic receptors may be directly exposed to sediment-associated contaminants by physical contact or ingestion, and by osmotic exchange, respiration, or ventilation of sediments in the water column or in pore water

\section{SELECTION AND USE OF TOXICITY DATA}

\section{Ecological assessment of toxicity effects}

Reference concentrations (RfCs) refer to concentrations of chemicals in media (for example, sediment, invertebrates, or water) where there are established no-observable-effect levels (NOELs) or NOAELs. Reference doses (RfDs) refer to concentrations of chemicals in media that when ingested or dermally applied are associated with no adverse effect.

Uncertainty factors will be used to adjust various available toxicity criteria to produce noobserved-effect toxicity criteria. Research on different species of birds exposed to 37 pesticides found that LC50s for the different species were approximately the same. Therefore, an uncertainty factor of 1 was the most appropriate between all classes of birds (Mineau and others, 1996). Based on guidance from DTSC (1996), the following uncertainty factors were used:

- Test species within the same taxonomic genus $U F_{1}=1$

- Test genera within the same taxonomic family $U F_{1}=1$

- Test families within the same taxonomic order $U F_{1}=5$

- Test order within the same taxonomic class $U F_{1}=10$

An effects level uncertainty factor $\left(U F_{2}\right)$ is used to adjust toxicity criteria representing various effects levels to the equivalent of a NOAEL so that they could be used as RfDs or RfCs. UF2 values (DTSC 1996) are recommended for lethal doses or concentrations ( $\mathrm{LD}_{50}, \mathrm{LC}_{50}$ ), lowestobservable-effect levels (LOEL), or lowest-observed-adverse-effect level (LOAEL) as follows:

\begin{tabular}{|c|c|}
\hline $\mathrm{LC}$ & $U F_{2}$ \\
\hline OI & $U F_{2}$ \\
\hline $\mathrm{OAEL}_{\mathrm{chro}}$ & $U F_{2}$ \\
\hline
\end{tabular}




\section{CALCULATION OF ESTIMATES OF EXPOSURE}

\section{Daily Dosage for Aquatic-Associated Shorebird (Invertebrate Consumer)}

The black-necked stilt was selected as the representative species—a shorebird that utilizes both terrestrial and aquatic-associated habitats. As secondary consumers, stilts represent exposure routes involving potential bioaccumulation of contaminants and food-web transfer. Ingestion of contaminated aquatic invertebrates is the primary route of exposure with incidental ingestion of sediments. The exposure model for ingestion is

$D i_{B N S}=\left\{\left[\left(C_{i} \times R_{d} \times F i\right)+\left(E C_{s} \times R_{d} \times F_{s}\right)\right] \div B W_{B N S}\right\} \times T_{f}$

Where

$$
\begin{aligned}
D i_{B N S} & =\text { daily dosage from ingestion } \\
C_{i} & =\text { concentrations of potentially toxic chemicals in invertebrates } \\
R_{d} & =\text { intake rate for black-necked stilt } \\
F_{i} & =\text { fraction of invertebrates in black-necked stilt diet } \\
C_{p} & =\text { concentrations of potentially toxic chemicals in plants } \\
F_{p} & =\text { fraction of plant in black-necked stilt diet } \\
E C_{s} & =\text { concentrations of potentially toxic chemicals in sediment } \\
F_{s} & =\text { fraction of soil in black-necked stilt diet } \\
B W_{B N S} & =\text { mean body weight of black-necked stilt } \\
T_{f} & =\text { fractional intake, or fraction of time spent in contact with contaminated } \\
& \text { sediments }
\end{aligned}
$$

Black-necked stilts both winter (September-February) and breed (May-August) at the Salton Sea. As it is not known whether breeding birds are yearlong residents, fractional intake is estimated conservatively at 1.0 for permanent aquatic habitat. However, concentrations of selenium in eggs generally represent recent (for example, $<1$ month) dietary exposure. The exposure factors for the black-necked stilt are presented below. 


\begin{tabular}{|c|c|c|}
\hline Parameter & Value & Reference \\
\hline \multicolumn{3}{|l|}{ General } \\
\hline Body Weight (kg) & $0.1696^{\mathrm{a}}$ & Robinson and Oring, 1996 \\
\hline $\begin{array}{l}\text { Foraging Area (ha) } \\
\text { Soil and Food Ingestion }\end{array}$ & no information & $\begin{array}{l}\text { Rigney, } 2001 \\
\text { • assume site use factor of } 1.0\end{array}$ \\
\hline Dietary Intake [mg/day(dry wt)] & $1.4219 \times 104$ & $\begin{array}{l}\text { Derived from U.S. Environmental Protection Agency, } \\
1993^{\mathrm{b}}\end{array}$ \\
\hline Soil Diet Proportion & 0.160 & $\begin{array}{l}\text { Derived from Hui and Beyer, } 1998 \\
\text { - assume ingestion is incidental based on feeding } \\
\text { behaviors (for example, probing, pecking) }\end{array}$ \\
\hline Plant Diet Proportion & 0.011 & Robinson and Oring, 1996 \\
\hline Animal Diet Proportion & 0.949 & Derived from Robinson and others, 1992 \\
\hline Water Intake (L/day) & 0 & Hamilton (1975) \\
\hline
\end{tabular}

${ }^{\mathrm{a}}=$ Mean value

$\mathrm{b}=$ Dietary Intake (DI) calculated using equation [3-5]: DI (g/day) $=0.301 \mathrm{Wt0} .751$ (g)

Hazard Quotients for Aquatic-Associated Shorebird (Invertebrate Consumer)

A hazard Quotient (HQ) is the ratio of the estimated exposure to the toxicity reference values (TRV, U.S. Geological Survey, 2001b):

$\mathrm{HQ}=\frac{\text { Estimated Exposure }}{-\mathrm{TRV}}$

The implicit assumption in characterizing risk is that, based on the estimated potential effects on individuals, inferences or extrapolations can be made to assessment endpoints or population-level effects. Chronic NOAEL-based HQs that exceed one suggest that adverse effects are possible to sensitive individuals, while chronic LOAEL-based HQs that exceed one suggest that adverse effects to most individuals are likely.

\section{UNCERTAINTY EVALUATION}

Uncertainties, which may lead to either overstatements or understatements of risk, are possible with any risk assessment methodology. Consistently conservative approaches in selecting literature values were used, and descriptions of the limitations of using any values chosen were provided. 
This page left intentionally blank. 
Publishing support provided by the U.S. Geological Survey Publishing Network, Tacoma Publishing Service Center

For more information concerning the research in this report, contact the Director, Western Ecological Research Center

3020 State University Drive East

Modoc Hall, Room 3006

Sacramento, CA 95819

http://www.werc.usgs.gov/ 
ฏ

总

i

ֻ

을

s

$\$$

客

品

क्ष

疍

3

을

를.

뭉

으.

?

응

인

픔

가

응

ᄀ

잉 